\title{
New Mechanism for Cinchona Alkaloid-Catalysis Allows for an Efficient Thiophosphorylation Reaction
}

\author{
Nastaran Salehi Marzijarani, ${ }^{* a}$ Yu-hong Lam, ${ }^{\text {, Xiao Wang, }}{ }^{\mathrm{c}}$ Artis Klapars, ${ }^{\mathrm{a}} \mathrm{Ji}$ Qi, ${ }^{\mathrm{a}, \mathrm{d}}$ Zhiyan Song,

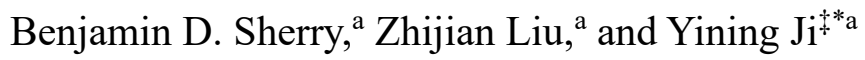 \\ ${ }^{a}$ Department of Process Research and Development, Merck \& Co., Inc., Rahway, NJ, United States \\ ${ }^{\mathrm{b}}$ Department of Computational and Structural Chemistry, Merck \& Co., Inc., Rahway, NJ, United States \\ ${ }^{c}$ Department of Analytical Research and Development, Merck \& Co., Inc., NJ, United States \\ ${ }^{\mathrm{d}}$ Department of Process Research and Development, MSD R\&D (China) Co., Ltd., Beijing, China \\ ${ }^{\mathrm{e}}$ Department of Synthetic Chemistry, Pharmaron Beijing Co., Ltd. Beijing, China
}

nastaran.salehi.marzijarani@merck.com \& yining.jichen@merck.com 


\section{Table of Contents}

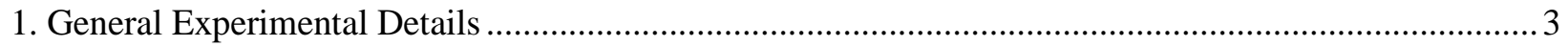

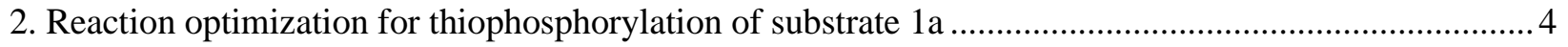

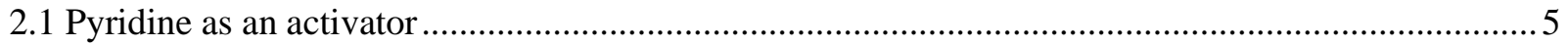

2.2 Computational modeling to understand the role of pyridine as a nucleophilic activator................... 6

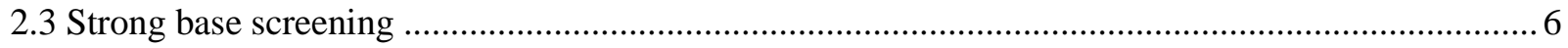

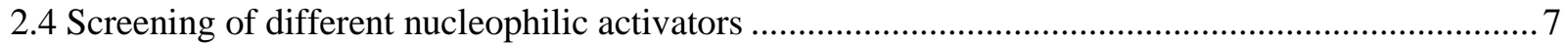

2.5 Optimization using a stoichiometric amount of quinine ….......................................................... 11

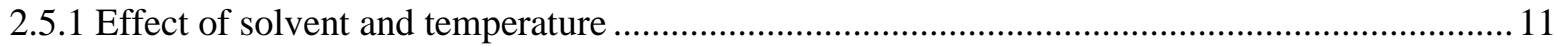

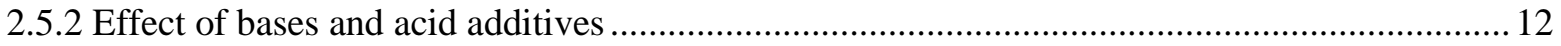

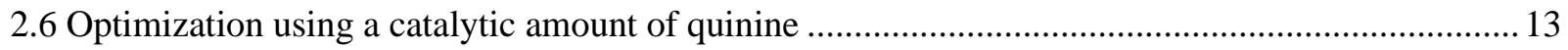

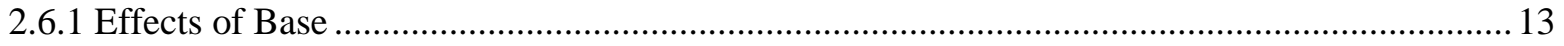

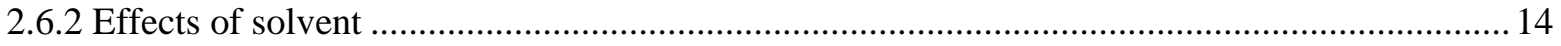

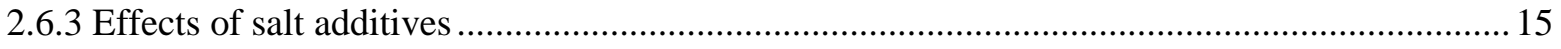

2.7 Role of quinine catalyst versus quinoline derivatives ................................................................. 16

2.8 Reaction performance and the importance of the chiral pocket...................................................... 18

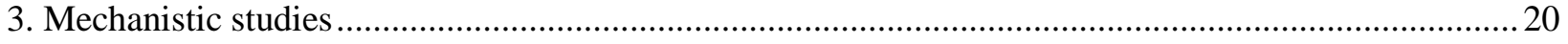

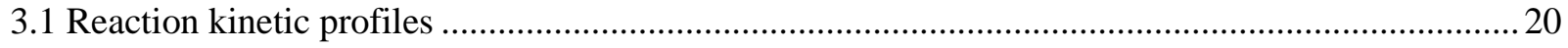

3.2 Determination of the reaction orders of each reaction components ................................................23

3.3 Kinetic profiles using different quinine derivatives.................................................................... 24

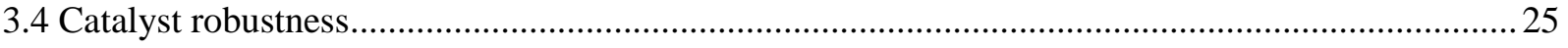

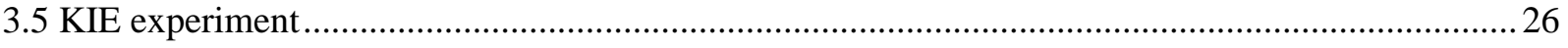

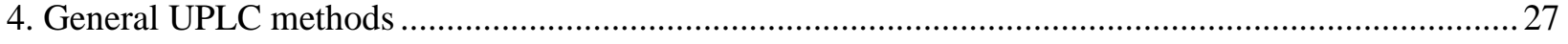

4.1 Short UPLC method - used to monitor thiophosphorylation reaction of nucleosides .....................2 27

4.2 Long UPLC method 1 used to monitor thiophosphorylation reaction of highly polar nucleosides.. 27

4.3 Long HPLC method 2 for monitoring the thiophosphorylation of highly polar nucleosides ...........28

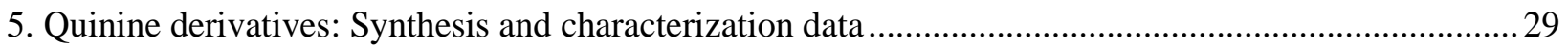

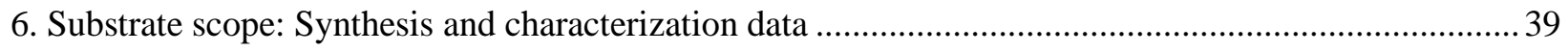

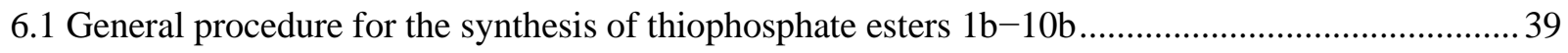

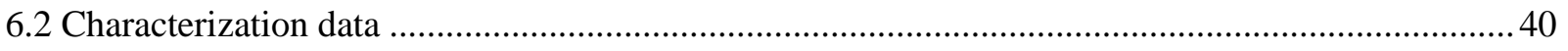

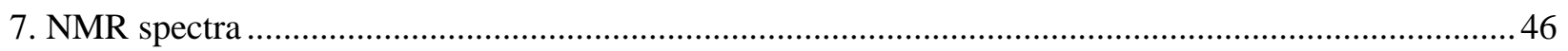

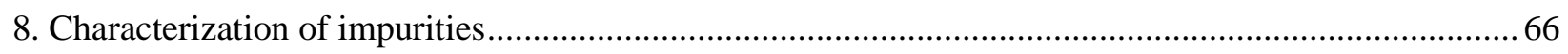

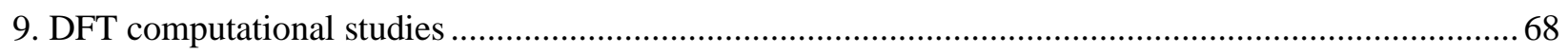

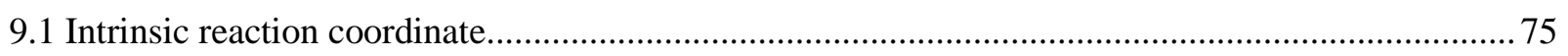

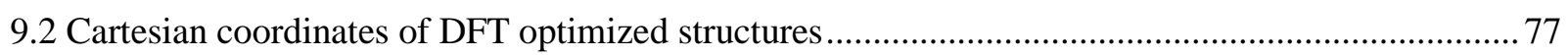




\section{General Experimental Details}

Unless otherwise noted, all reactions were performed under an $\mathrm{N}_{2}$-atmosphere. Heating of reaction mixtures was performed using a temperature-controlled hotplate equipped with stirring and an active thermocouple. The stirring of reaction mixtures was performed using magnetic stirring unless noted otherwise. Evaporation and concentration in vacuo were done using a variable vacuum via a vacuum controller (ca. 400-40 mmHg).

Materials. Quinine (Q1) catalyst was purchased from Acros Organics in 99\% purity. Quinine hydrochloride (Q6) was purchased from Sigma Aldrich as a dihydrate form. N-Benzylquininium chloride (Q2) was purchased from Sigma Aldrich in 95\% purity and used in the reaction without further purification. Thiophosphoryl chloride ( $\mathrm{PSCl}_{3}$ ) was purchased from TCI America or Sigma Aldrich in $98 \%$ purity. THF solvent was ordered from Acros Organics (99.5\%, extra dry over molecular sieves, stabilized). All other reagents were purchased in reagent grade from different commercial suppliers and used without further purification unless otherwise described. Anhydrous solvents were obtained from Sigma Aldrich as part of their Sure/Seal ${ }^{\mathrm{TM}}$ bottles product line. NMR kinetic experiments utilized $d 8$-tetrahydrofuran (100\% purity, $>99.95 \% d 8$-content, catalog DLM-56-10X0.75) was purchased from Cambridge Isotope Laboratories in sealed ampules and used as received.

Instrumentation. Proton nuclear magnetic resonance $\left({ }^{1} \mathrm{H}\right.$ NMR) spectra, carbon nuclear magnetic resonance $\left({ }^{13} \mathrm{C} \mathrm{NMR}\right)$ spectra, and proton decoupled fluorine nuclear magnetic resonance $\left({ }^{19} \mathrm{~F} \mathrm{NMR}\right)$ were recorded at $25{ }^{\circ} \mathrm{C}$ (unless stated otherwise) on a Bruker DRX-400 spectrometer. Chemical shifts for protons are reported in parts per million downfield from tetramethylsilane and are referenced to the residual proton of the NMR solvent according to values reported in the literature. ${ }^{1}$ Chemical shifts for carbon are reported in parts per million downfield from tetramethylsilane and are referenced to the carbon resonances of the NMR solvent. Data are represented as follows: chemical shift, integration, multiplicity $(\mathrm{br}=$ broad, $\mathrm{s}=$ singlet, $\mathrm{d}=$ doublet, $\mathrm{t}=$ triplet, $\mathrm{q}=$ quartet, quint = quintet, $\mathrm{m}=$ multiplet, $\mathrm{dt}=$ doublet of triplets), coupling constants $(J)$ in Hertz $(\mathrm{Hz})$. Analysis of reaction mixtures, and quantification of starting material and product, was done using a quantitative ${ }^{19} \mathrm{~F}$ NMR analysis $\left({ }^{19} \mathrm{~F}\right.$ qNMR, $\mathrm{d} 1=60$ seconds, number of scans $=$ 8).

1 (a) Gottlieb, H. E.; Kotlyar, V.; Nudelman, A. J. Org. Chem. 1997, 62, 7512-7515. (b) Fulmer, G. R.; Miller, A. J. M. Sherden, N. H.; Gottlieb, H. E.; Nudelman, A.; Stoltz, B. M. Bercaw, J. E.; Goldberg, K. I. Organometallics 2010, 29, 2176-2179. 


\section{Reaction optimization for thiophosphorylation of substrate 1a}

The goal was to identify the best synthetic route to prepare 3'F-thio-PGMP (1b) from iso-Bu-3'F-G (1a) in high yield, short steps, and high purity. This task was very challenging, and low reactivity and selectivity were observed.

Main reaction impurities. The possible mechanism for the formation of impurities is shown in the scheme S1. Overreactivity and lack of $\mathbf{1 b}$ product selectivity are the root causes for the formation of overphosphorylated impurity $\mathbf{1 d}$. Product $\mathbf{1 b}$ can also react with starting material $\mathbf{1 a}$ to provide dimerized impurity 1e. More extended aging of the product $\mathbf{1 b}$ at a higher temperature (above $0{ }^{\circ} \mathrm{C}$ ) has a significant role in developing chlorinated side products $\mathbf{1 f}$ and $\mathbf{1 g}$.

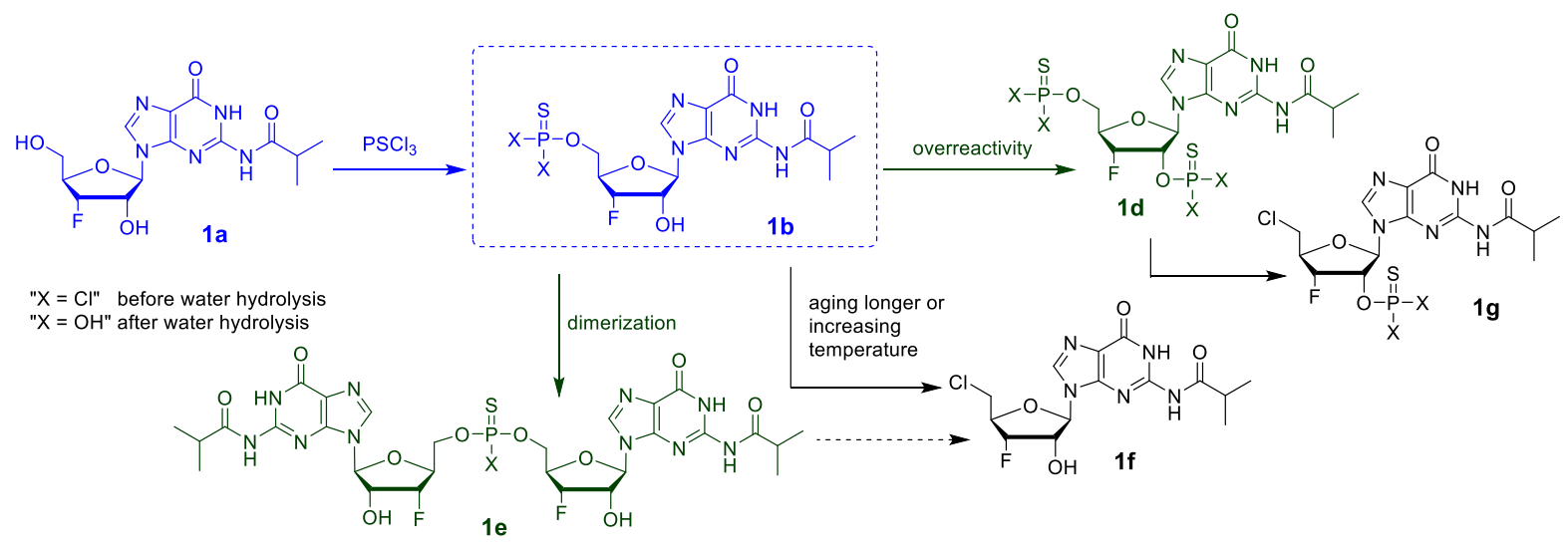

Scheme S1. A possible mechanism for the formation of side products.

Based on DFT calculations, it was found that the desired 5'-isomer (1) is the thermodynamically more stable product, whereas the 2'-regioisomer is the kinetically favored product (1c).

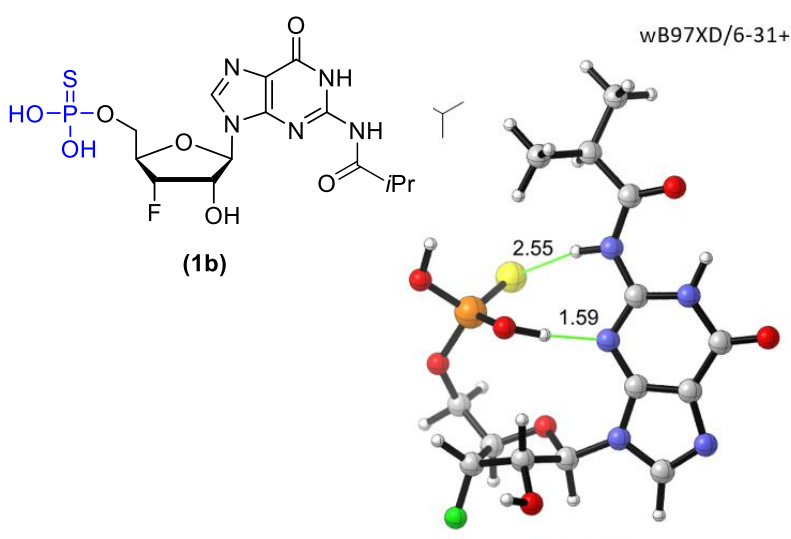

$\mathrm{G}_{\mathrm{rel}}=0$

Thermodynamic product

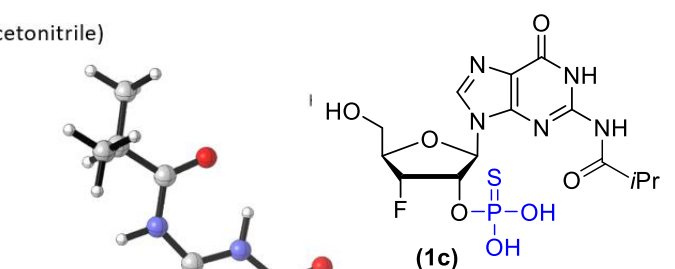

(1c) $\mathrm{OH}$

Scheme S2. Energies of the thermodynamic (1b) and kinetic product (regioisomer 1c). 
2.1 Pyridine as an activator. Compound 1a has low solubility in most organic solvents, below $1 \mathrm{mg} / \mathrm{mL}$ in MeCN, DME, IPAC, and $2.3 \mathrm{mg} / \mathrm{mL}$ in THF. Interestingly, the solubility of 1a was very high in pyridine $(320 \mathrm{mg} / \mathrm{mL})$. Table S1 summarizes thiophosphorylation screenings where pyridine is used both as a base and/or a solvent. The reaction was first optimized at room temperature using five equivalents of pyridine. It was discovered that at temperatures above $0{ }^{\circ} \mathrm{C}$, a chlorinated side product (1f) is formed as the major byproduct, arising from $\mathrm{SN}_{2}$ chlorination of the final dichlorothiophosphate product prior to water quench. Increasing the equivalents of pyridine by including it as a cosolvent led to a significant improvement in conversion; however, the final dichlorothiophosphate product was not stable and decomposed to side products over time. Changing $\mathrm{PSCl}_{3}$ equivalents, temperature, and solvent, improved the final yield of $\mathbf{1 b}$ slightly, the highest of $85.3 \%$ upon using a Proton Sponge (1,8-bis(dimethylamino)naphthalene) as an additive with $2.5 \mathrm{eq} \mathrm{PSCl}_{3}$ at $-20{ }^{\circ} \mathrm{C}$. The moderate yield for $\mathbf{1 b}$ was due to a lack of selectivity and the formation of overphosphorylated (1d) and dimerized (1e) impurities.

Table S1. Reaction optimization for the synthesis of $\mathbf{1 b}$ using pyridine.

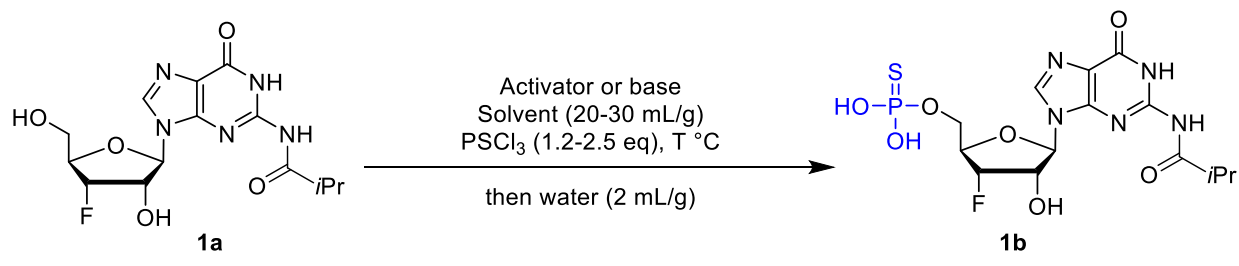

\begin{tabular}{ccccccc}
\hline Entry & Activator/Additive/Base & $\mathbf{P S C l}_{3}$ (eq) & $\mathbf{T}^{\circ} \mathbf{C}$ & Solvent & (1b)\% & Conv\% \\
\hline 1 & Pyridine (5 eq) & 1.5 & 25 & MeCN & 8.0 & 100.0 \\
2 & Pyridine (5 eq) & 1.5 & 25 & THF & - & 100.0 \\
3 & Pyridine (10 eq) & 1.5 & 0 & DMAc & 31.0 & 50.7 \\
4 & Pyridine (10 eq) & 1.5 & 0 & TMP & 66.6 & 95.7 \\
5 & Pyridine (10 eq) & 1.5 & 0 & DME & 66.1 & 96.1 \\
6 & Pyridine (10 eq) & 1.5 & 0 & Diglyme & 64.5 & 93.6 \\
7 & - & 1.2 & 0 & Pyridine:THF (1:1) & 69.9 & 86.0 \\
8 & - & 0 & Pyridine:THF (1:1) & 70.2 & 97.4 \\
9 & Proton Sponge (5 eq) & 1.5 & 0 & Pyridine:THF (1:1) & 75.8 & 97.3 \\
10 & Et ${ }_{3} \mathrm{~N}$ (1 eq) & 1.5 & 0 & Pyridine:THF (1:1) & 62.9 & 97.6 \\
11 & Proton Sponge (2 eq) & 2.5 & -20 & Pyridine:DCE (1:1) & 85.3 & 96.7 \\
12 & - & 1.5 & -20 & Pyridine & 80.9 & 96.8 \\
13 & - & 5.0 & -20 & Pyridine & 83.5 & 95.9 \\
\hline
\end{tabular}




\subsection{Computational modeling to understand the role of pyridine as a nucleophilic activator. Based}

on the DFT calculations shown below, we propose a mechanism where pyridine acts as an activator for increasing the electrophilicity of the $\mathrm{PSCl}_{3}$ reagent. $\mathrm{PSCl}_{3}$ and pyridine can form an adduct with an activation barrier of $9.3 \mathrm{kcal} / \mathrm{mol}$ (TS1), which can further react to generate the product complex via a 12.0 $\mathrm{kcal} / \mathrm{mol}$ energy and transition state (TS2) as shown in Scheme S3. All barriers are low; therefore, the activated phosphorus species' formation is expected to be equilibrium controlled. This observation further confirmed the importance of pyridine for reactivity and activation of thiophosphorylating reagents.

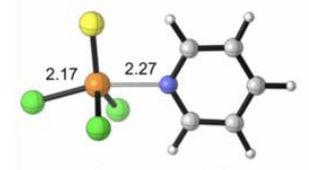

TS1: TS for P-N bond formation

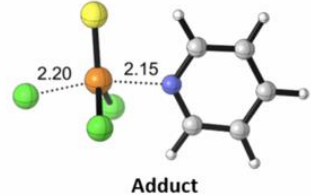

Adduct

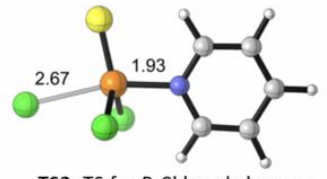

TS2: TS for $\mathrm{P}-\mathrm{Cl}$ bond cleavage Rate-determining TS

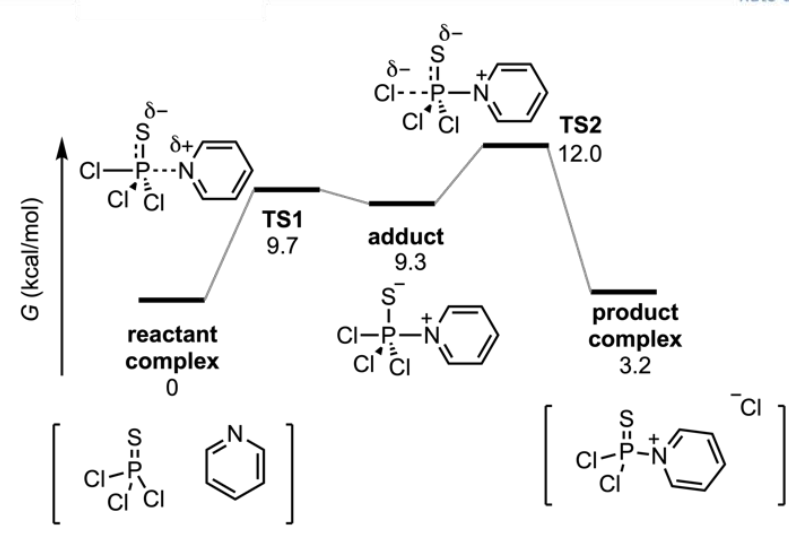

Scheme S3. A possible mechanism for the role of pyridine in the activation of $\mathrm{PSCl}_{3}$.

2.3 Strong base screening. Next, other activators and additives were screened to improve the yield for compound 1b. At first, different strong bases were screened to increase the nucleophilicity of 5'-OH and enhance the nucleoside's reactivity in the absence of any pyridine or activators. THF as an organic solvent, was tested in combination with $\mathrm{KO}^{t} \mathrm{Bu}$, KO'Pent, LiHMDS, NaHMDS, and KHMDS in various loadings, as shown in Table S2. Unfortunately, none of these conditions provided any product at desirable levels; instead, the undesired 2'-regioisomer (1c) was formed as the major product. The screening of strong bases revealed the requirement for discovering an ideal activator or catalyst for the thiophosphorylation of nucleosides. 
Table S2. Strong base screening for the synthesis of $\mathbf{1 b .}$

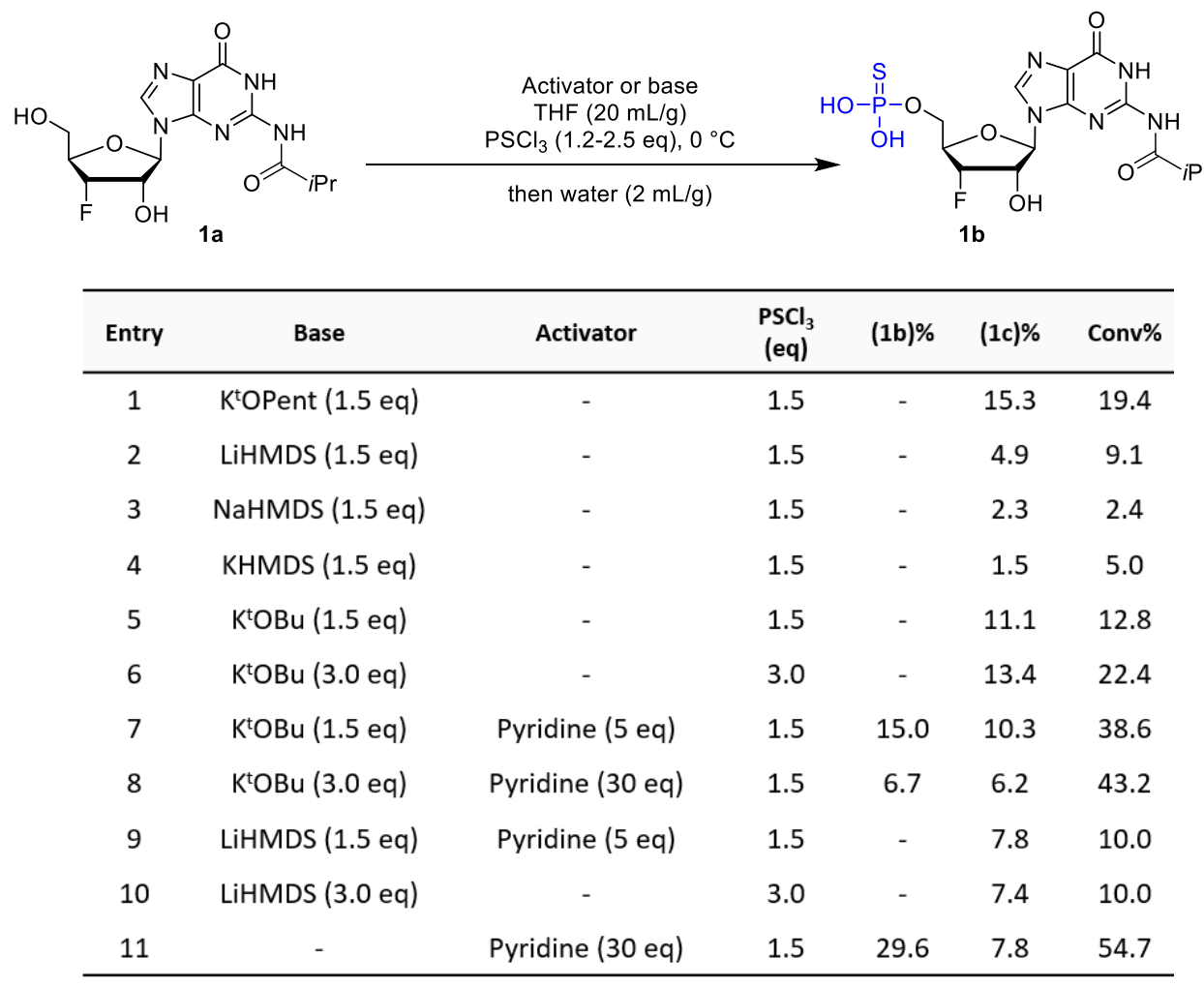

2.4 Screening of different nucleophilic activators. Next, various nucleophilic catalysts/additives were screened to promote the thiophosphorylation reaction in high reactivity and selectivity. As shown in the previous section, highly basic conditions resulted either in low reactivity or the undesired regioisomer's formation. Nucleophilic additives (such as pyridine) gave low selectivity and an unstable end of the reaction stream (EOR). Therefore, a new catalyst with the proper nucleophilicity toward the activation of $\mathrm{PSCl}_{3}$, combined with a mild base, was crucial.

First, N-methyl imidazole was screened combined with 2,6-lutidine as a mild base, in different equivalents and various solvents. Substrate 1a' was utilized in this screening (lengthy chain protecting group) to minimize the solubility risk (Table S3). Unfortunately, the reaction was very messy or provided low yields. Other bases, such as $\mathrm{KO}^{\mathrm{t}} \mathrm{Bu}$ and Proton Sponge, were screened in place of 2,6-lutidine and showed no yield improvement. 
Table S3. Screening of N-methyl imidazole for thiophosphorylation of 1a'.

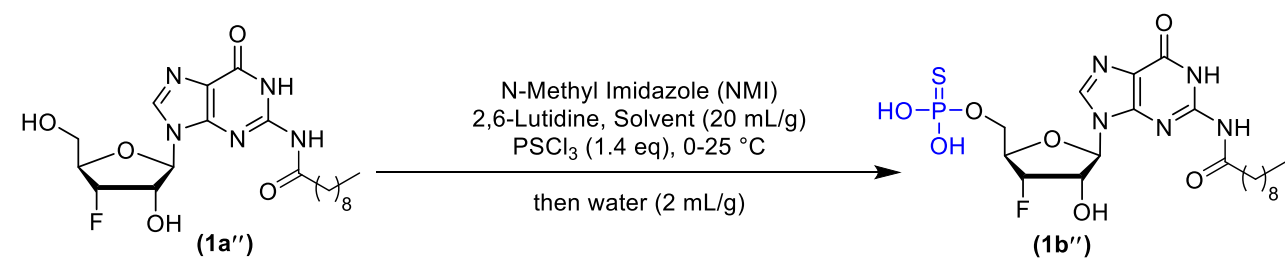

\begin{tabular}{cccccc}
\hline Entry & Solvent & NMI (eq) & $(\mathbf{1 b}$ ")\% & $(\mathbf{1 c}$ ")\% & Conv\% \\
\hline 1 & THF & 0 & 27.1 & 8.1 & 45.9 \\
2 & MeCN & 0.25 & 6.2 & 17.0 & 27.1 \\
3 & MeCN & 3.0 & 6.4 & - & 26.0 \\
4 & MeCN & 20.0 & - & - & messy \\
5 & THF & 0.25 & 13.5 & 8.3 & 33.9 \\
9 & THF & 3.0 & - & - & messy \\
10 & THF & 20.0 & - & - & messy \\
\hline
\end{tabular}

Next, a broader number of nucleophilic activators were screened, as shown in Table S4. The highest conversion was achieved with cinchonidine (15) as the activator and pyridine as a base (96.6\% conversion); however, selectivity was very low, and only $44.4 \%$ desired product was formed (entry 20). The highest selectivity was achieved with quinine (entries 17-19). In the absence of any base and using 2.5 equivalents of quinine, the desired monothiophosphate product was formed with $42.3 \%$ conversion and $38.7 \%$ yield. The use of Proton Sponge helped improve the reactivity to $76.7 \%$ while maintaining good selectivity (entry 19). The pyridine N-oxide family, especially 4-methyl pyridine N-oxide, was discovered to be a good activator for $\mathrm{PSCl}_{3}$, and $95.1 \%$ conversion was obtained; however, a dimerized impurity was found to be the major side product for this reaction (entries 13-16). 
Table S4. Activator screening for thiophosphorylation reaction.

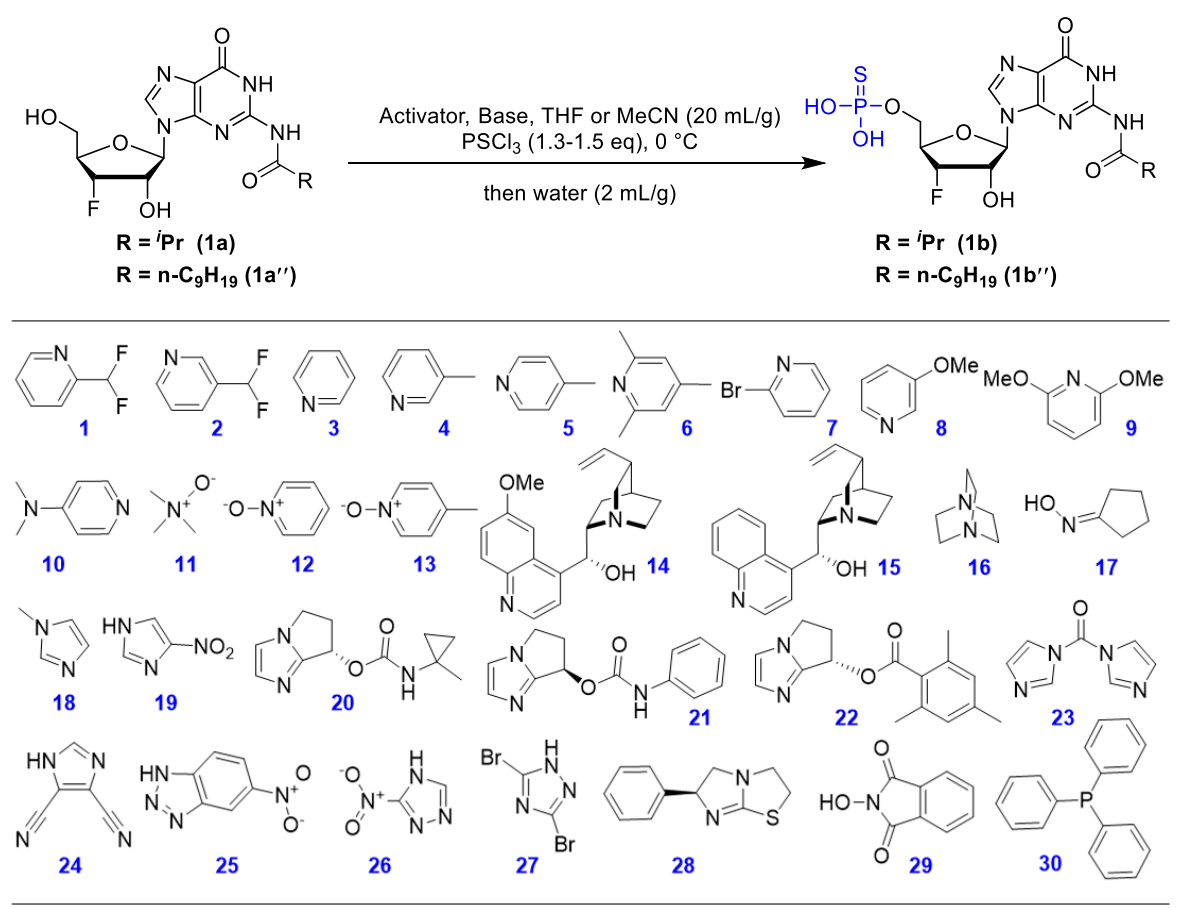

\begin{tabular}{|c|c|c|c|c|c|c|c|}
\hline Entry & Substrate & Activator & $\begin{array}{c}\text { Activator } \\
\text { (equiv) }\end{array}$ & Base & Solvent & (1b or $1 b ") \%$ & Conv\% \\
\hline 1 & $1 a^{\prime \prime}$ & 1 & 10.0 & - & THF & 1.6 & 12.2 \\
\hline 2 & $1 a^{\prime \prime}$ & 2 & 10.0 & - & THF & 15.6 & 33.6 \\
\hline 3 & $1 a^{\prime \prime}$ & 3 & 10.0 & - & THF & 28.3 & 47.0 \\
\hline 4 & 1a" & 4 & 10.0 & - & THF & 31.2 & 47.0 \\
\hline 5 & $1 a^{\prime \prime}$ & 5 & 10.0 & - & THF & 33.6 & 51.3 \\
\hline 6 & $1 a^{\prime \prime}$ & 6 & 10.0 & - & THF & 12.2 & 15.0 \\
\hline 7 & $1 a^{\prime \prime}$ & 7 & 10.0 & - & THF & 6.5 & 9.7 \\
\hline 8 & $1 a^{\prime \prime}$ & 8 & 10.0 & - & THF & 11.7 & 44.5 \\
\hline 9 & $1 a^{\prime \prime}$ & 9 & 10.0 & - & THF & 1.6 & 4.1 \\
\hline 10 & $1 a$ & 10 & 1.0 & - & THF & 7.1 & 23.3 \\
\hline 11 & $1 a^{\prime \prime}$ & 11 & 10.0 & - & THF & 2.1 & 9.0 \\
\hline 12 & $1 a^{\prime \prime}$ & 12 & 10.0 & - & THF & 19.4 & 23.7 \\
\hline 13 & 1a & 13 & 0.25 & - & THF & 25.6 & 82.1 \\
\hline 14 & 1a & 13 & 0.5 & - & THF & 35.8 & 95.1 \\
\hline 15 & 1a & 13 & 0.5 & - & $\mathrm{MeCN}$ & 44.7 & 68.2 \\
\hline 16 & $1 a$ & 13 & 1.5 & pyridine & THF & 4.9 & 73.2 \\
\hline 17 & $1 a^{\prime \prime}$ & 14 & 2.5 & - & THF & 38.7 & 42.3 \\
\hline 18 & $1 a$ & 14 & 2.5 & pyridine & THF & 49.5 & 64.1 \\
\hline 19 & 1a & 14 & 1.0 & proton sponge & THF & 73.1 & 76.7 \\
\hline 20 & 1a & 15 & 1.0 & pyridine & THF & 44.4 & 96.6 \\
\hline 21 & $1 a$ & 15 & 1.0 & proton sponge & THF & 34.9 & 37.1 \\
\hline
\end{tabular}




\begin{tabular}{|c|c|c|c|c|c|c|c|}
\hline Entry & Substrate & Activator & $\begin{array}{c}\text { Activator } \\
\text { (equiv) }\end{array}$ & Base & Solvent & (1b or $\left.1 b^{\prime \prime}\right) \%$ & Conv\% \\
\hline 22 & 1a" & 16 & 1.0 & - & THF & 8.0 & 24.1 \\
\hline 23 & $1 a$ & 16 & 1.0 & pyridine & THF & 17.9 & 30.3 \\
\hline 24 & 1a" & 16 & 1.0 & 2,6-Lutidine & THF & 8.0 & 24.1 \\
\hline 25 & $1 a$ & 17 & 1.0 & pyridine & THF & 2.7 & 13.4 \\
\hline 26 & 1a" & 18 & 1.0 & 2,6-Lutidine & THF & 23.5 & 58.4 \\
\hline 27 & 1a" & 19 & 1.0 & 2,6-Lutidine & THF & 8.0 & 19.0 \\
\hline 28 & 1a" & 20 & 1.0 & 2,6-Lutidine & $\mathrm{MeCN}$ & 27.3 & 56.0 \\
\hline 29 & 1a" & 20 & 1.0 & 2,6-Lutidine & THF & 32.4 & 53.2 \\
\hline 30 & $1 a$ & 20 & 1.0 & proton sponge & THF & 11.2 & 35.9 \\
\hline 31 & $1 a^{\prime \prime}$ & 21 & 1.0 & 2,6-Lutidine & THF & 20.4 & 33.0 \\
\hline 32 & 1a & 22 & 1.0 & pyridine & THF & 35.5 & 78.4 \\
\hline 33 & 1a & 22 & 1.0 & proton sponge & THF & 25.2 & 42.1 \\
\hline 34 & $1 a$ & 23 & 1.0 & proton sponge & THF & 3.2 & 57.5 \\
\hline 35 & 1a & 24 & 1.0 & proton sponge & THF & 24.9 & 53.2 \\
\hline 36 & 1a" & 25 & 1.0 & 2,6-Lutidine & THF & 6.9 & 17.0 \\
\hline 37 & 1a" & 26 & 1.0 & 2,6-Lutidine & THF & 8.4 & 22.0 \\
\hline 38 & $1 a$ & 26 & 1.0 & proton sponge & THF & 18.6 & 28.2 \\
\hline 39 & 1a" & 27 & 1.0 & 2,6-Lutidine & THF & 9.2 & 21.0 \\
\hline 40 & $1 a$ & 28 & 1.0 & proton sponge & THF & 11.6 & 21.1 \\
\hline 41 & $1 a$ & 29 & 1.0 & proton sponge & THF & 0 & 4.2 \\
\hline 42 & $1 a$ & 30 & 1.0 & proton sponge & THF & 0 & 52.6 \\
\hline
\end{tabular}

Thiophosphorylation reaction was less sensitive to the solvent, protecting group, or the base than the activator. The high-throughput fashion (HTE) result of the thiophosphorylation has been summarized from each family of activators in Figure S1. In most cases, reactivity and selectivity are at opposite ends. The pyridine and pyridine N-oxide family showed great reactivity; however, they suffered from selectivity. Quinine showed low reactivity during the first screening but displayed excellent selectivity. In summary, quinine was found to be a unique activator in terms of selectivity toward the desired product. The equivalents of quinine, base, and solvent were screened (next section) to improve the reaction's reactivity. 


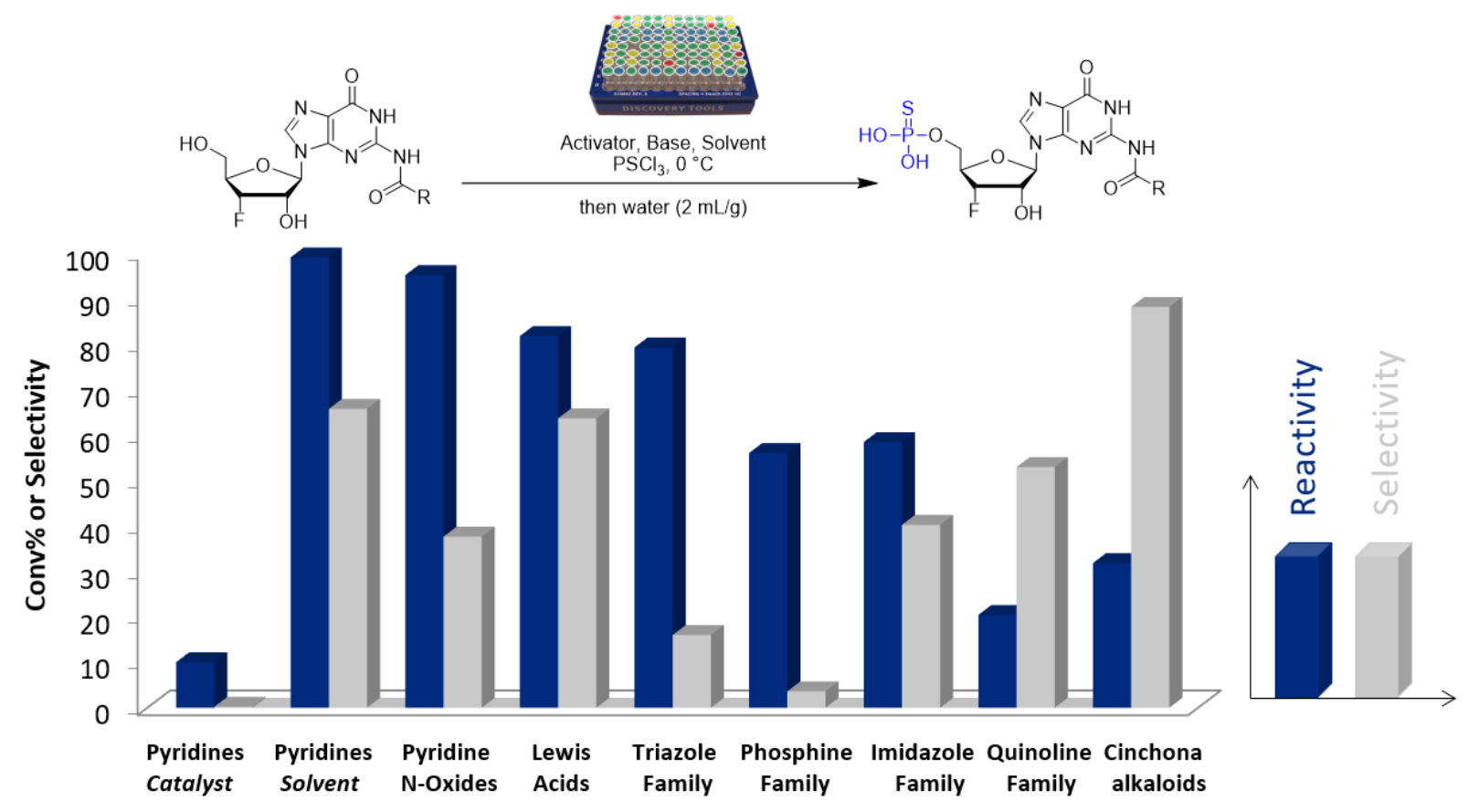

Figure S1. Summary of HTE screenings.

\subsection{Optimization using a stoichiometric amount of quinine}

2.5.1 Effect of solvent and temperature. Different stoichiometric amounts of quinine activator were utilized in combination with various solvents and temperatures in the absence of any external bases to improve the overall reaction performance, as shown in Table S5. Increasing the amount of quinine to 2.0 and 5.0 equivalents did not result in any improvements. THF was found to be the best candidate for the thiophosphorylation reaction using quinine among all solvents screened. Increasing the temperature to above $10{ }^{\circ} \mathrm{C}$ resulted in the formation of chlorinated side products over time. Compound $\mathbf{1 b}$ was formed with $61.8 \%$ yield, $79.2 \%$ conversion using THF as the solvent, and one equivalent of quinine at $0{ }^{\circ} \mathrm{C}$, with $4.9 \%$ overphosphorylated impurity (1d) and 1.6\% dimerized impurity $1 \mathbf{1 e}($ entry 13 ). 
Table S5. Solvent and temperature screening using a stoichiometric amount of quinine.

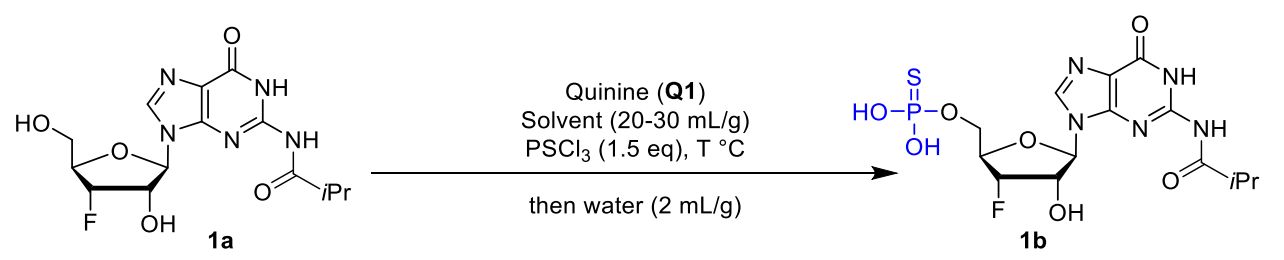

\begin{tabular}{ccccccccc}
\hline Entry & Quinine (eq) & Solvent & $\mathbf{T}^{\circ} \mathrm{C}$ & Time & $\mathbf{( 1 \mathbf { b } ) \%}$ & $\mathbf{( 1 \mathbf { d } ) \%}$ & $\mathbf{( 1 \mathbf { e } ) \%}$ & Conv\% \\
\hline 1 & 1.0 & HFIP & 10 & $20 \mathrm{~h}$ & 1.1 & - & - & 1.1 \\
2 & 1.0 & DMPU & 10 & $20 \mathrm{~h}$ & 0.9 & - & - & 9.2 \\
3 & 1.0 & Acetone & 10 & $20 \mathrm{~h}$ & 19.6 & - & - & 20.9 \\
4 & 1.0 & DMAc & 10 & $20 \mathrm{~h}$ & 3.9 & - & 9.7 & 35.3 \\
5 & 1.0 & THF & 25 & $3 \mathrm{~h}$ & 79.5 & 1.6 & 1.5 & 93.5 \\
6 & 1.0 & THF & 45 & $2 \mathrm{~h}$ & 44.5 & 2.4 & 2.6 & 100 \\
7 & 1.0 & MeCN & 25 & $3 \mathrm{~h}$ & 41.7 & 1.6 & 0.6 & 44.8 \\
8 & 1.0 & Glyme & 45 & $2 \mathrm{~h}$ & 44.8 & 1.9 & 5.6 & 79.1 \\
9 & 1.0 & DME & 45 & $2 \mathrm{~h}$ & 49.6 & 2.5 & 4.9 & 81.8 \\
10 & 1.0 & DME & 25 & $2 \mathrm{~h}$ & 25.0 & 4.9 & 1.1 & 38.1 \\
11 & 2.0 & DME & 25 & $2 \mathrm{~h}$ & 44.3 & 4.7 & 1.7 & 58.3 \\
12 & 5.0 & DME & 25 & $2 \mathrm{~h}$ & 45.9 & 4.0 & 2.5 & 72.7 \\
13 & 1.0 & THF & 0 & $8 \mathrm{~h}$ & 61.8 & 4.9 & 1.6 & 79.2 \\
14 & 2.0 & THF & 10 & $1 \mathrm{~d}$ & 11.1 & - & 28.1 & 55.7 \\
\hline
\end{tabular}

2.5.2 Effect of bases and acid additives. Different bases and acid additives were screened with one equivalent of quinine to improve the overall reaction profile (Table S6). Acid additives decreased the reactivity significantly (entries 1-2). Basic additives were found to help with reactivity; however, due to a high background reaction with pyridine, selectivity was lower (entries 4-7). Hunig's base and quinuclidine were not effective bases in this transformation (entries 9-11). The best reactivity and selectivity were obtained with 2,6-lutidine and Proton Sponge (entries 8, 16-18). Product $\mathbf{1 b}$ was synthesized in $91.7 \%$ using five equivalents of 2,6-lutidine and one equivalent of quinine in THF at $0{ }^{\circ} \mathrm{C}$ as the best reaction condition using a stoichiometric amount of quinine as an activator (entry 18). 
Table S6. Base screening using a stoichiometric amount of quinine activator.

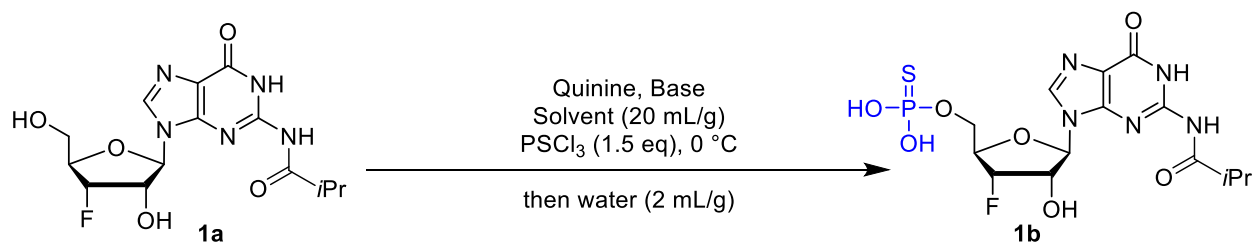

\begin{tabular}{cccccccccc}
\hline Entry & Quinine (eq) & Base/additive & Solvent & T $^{\circ} \mathbf{C}$ & Time & (1b)\% & (1d)\% & (1e)\% & Conv\% \\
\hline 1 & 1.0 & Benzoic acid ( 1 eq) & THF & 10 & $20 \mathrm{~h}$ & 49.6 & - & 5.1 & 62.3 \\
2 & 1.0 & Picolinic acid ( 1 eq) & THF & 10 & $20 \mathrm{~h}$ & 6.9 & - & 6.3 & 24.9 \\
3 & 1.0 & pyridine (5 eq) & DME & 0 & $7 \mathrm{~h}$ & 16.6 & 2.8 & 4.5 & 32.4 \\
4 & 1.0 & pyridine (5 eq) & THF & 0 & $7 \mathrm{~h}$ & 64.3 & 4.3 & 3.7 & 79.8 \\
5 & 1.0 & pyridine (5 eq) & THF & 10 & $1 \mathrm{~d}$ & 21.8 & - & 25.9 & 68.7 \\
6 & 1.0 & pyridine (5 eq) & MeCN & 0 & $7 \mathrm{~h}$ & 56.3 & 10.2 & 6.5 & 80.2 \\
7 & 1.0 & pyridine (5 eq) & EtOAc & 0 & $7 \mathrm{~h}$ & 29.8 & 2.3 & 1.0 & 33.1 \\
8 & 1.0 & proton sponge (1.5 eq) & THF & 0 & $6 \mathrm{~h}$ & 73.1 & 1.6 & 0.9 & 76.7 \\
9 & 1.0 & Hunig's base (5 eq) & THF & 10 & $1 \mathrm{~d}$ & 3.4 & - & 8.4 & 34.5 \\
10 & 1.0 & Hunig's base (2 eq) & THF & 25 & $17 \mathrm{~h}$ & 42.8 & - & 6.3 & 80.9 \\
11 & 1.0 & Quinuclidine (2 eq) & THF & 10 & $1 \mathrm{~d}$ & 4.1 & - & 6.1 & 33.1 \\
12 & 1.0 & 6-OMe-quinoline (5 eq) & THF & 10 & $1 \mathrm{~d}$ & 14.1 & - & 22.5 & 49.7 \\
13 & 1.0 & Trimethyl pyridine (2 eq) & THF & -15 & $21 \mathrm{~h}$ & 73.8 & - & - & 89.5 \\
14 & 1.0 & 4-methyl pyridine (2 eq) & THF & -15 & $21 \mathrm{~h}$ & 66.3 & - & - & 85.3 \\
15 & 1.0 & 3-OMe pyridine (2 eq) & THF & -15 & $21 \mathrm{~h}$ & 64.1 & - & - & 84.7 \\
16 & 1.0 & 2,4-Lutidine (5 eq) & THF & 10 & $20 \mathrm{~h}$ & 69.8 & 4.4 & 8.1 & 97.8 \\
17 & 1.0 & 2,4-Lutidine (2 eq) & THF & 25 & $17 \mathrm{~h}$ & 28.9 & - & 18.9 & 99.9 \\
18 & 1.0 & 2,6-Lutidine (5 eq) & THF & 0 & $21 \mathrm{~h}$ & 91.7 & 2.5 & 2.3 & 98.6 \\
\hline
\end{tabular}

\subsection{Optimization using a catalytic amount of quinine}

2.6.1 Effects of Base. The reaction was further optimized to reduce the level of quinine from stoichiometric to catalytic amounts. Various bases such as pyridine derivatives were screened using 50 mol\% quinine in THF at $0{ }^{\circ} \mathrm{C}$, as shown in Table S7. Quinine (50 mol\%) and 2,6-lutidine (1.5 equiv) were the best candidates among all the pyridine derivatives tested. The plot shows the reaction profile and relative rates of pyridine derivatives as bases. The fastest reaction rate and highest conversion were obtained with trimethyl pyridine; however, the final yield for the desired product was higher using 2,6-lutidine. Ortho substituted, and sterically hindered pyridines showed the lowest rates and yields (entries F and G). 
Table S7. Reaction optimization using a sub-stoichiometric amount of quinine and various bases.
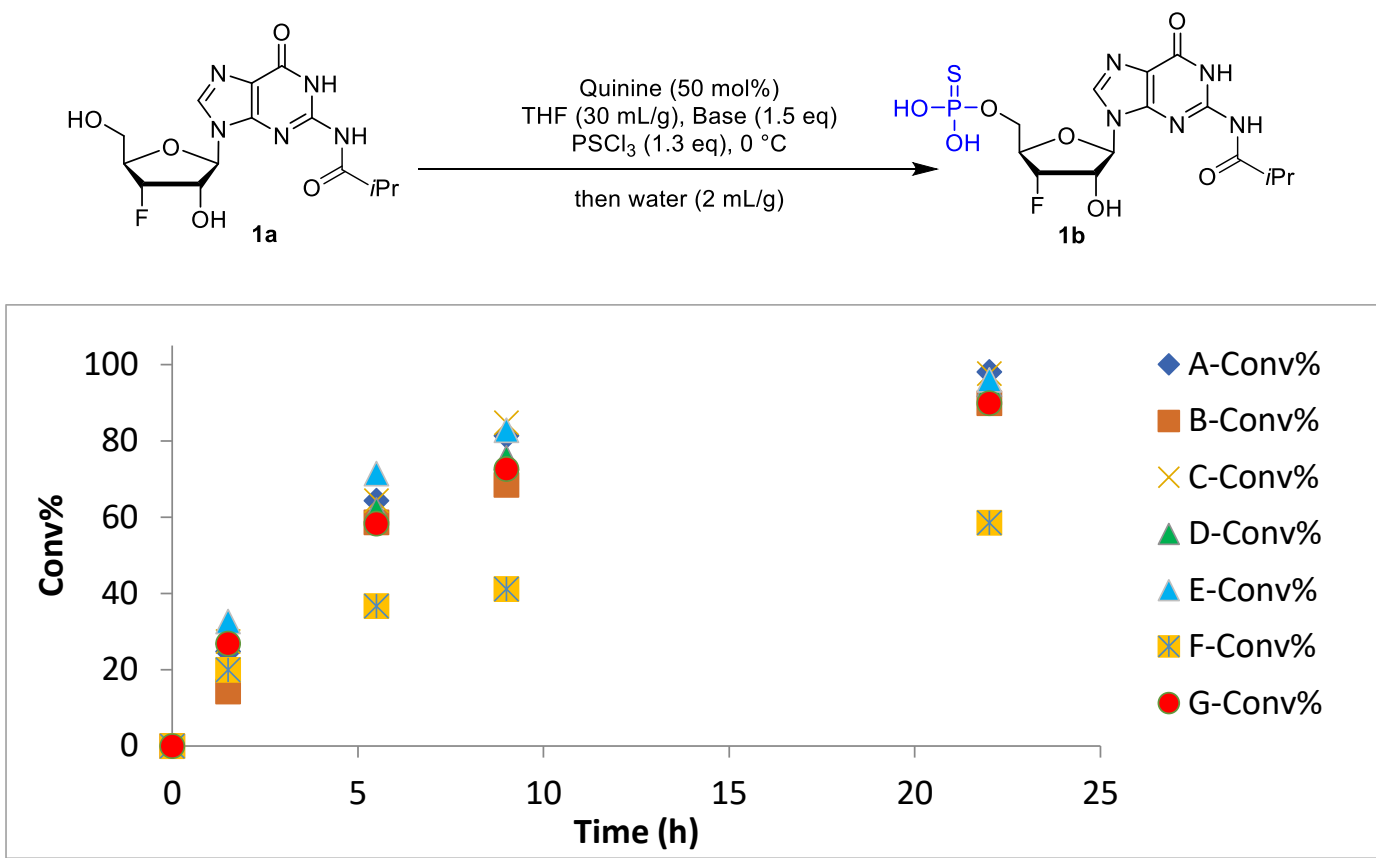

\begin{tabular}{ccc}
\hline Entry & Base & (1b)\% \\
\hline A & 2,6-lutidine & 92.7 \\
B & 2,4-lutidine & 79.0 \\
C & 2,4,6-trimethyl pyridine & 89.6 \\
D & 3-methyl pyridine & 78.7 \\
E & 4-methyl pyridine & 75.0 \\
F & 2,6-di-tert Butyl 4-methyl pyridine & 52.1 \\
G & 2-methyl pyridine & 76.8 \\
\hline
\end{tabular}

2.6.2 Effects of solvent. Different organic solvents than THF were screened after the discovery of quinine and 2,6-lutidine as the best catalyst and base, respectively (Table S8). Solvents such as acetone, 2-Me-THF, EtOAc, and MIBK showed poor performance with the quinine-catalyzed thiophosphorylation reaction, mainly due to low reactivity. The desired product (1b) was obtained at $83.8 \%$ (96.9\% conversion) using $\mathrm{MeCN}$ as the solvent, slightly lower than the THF system. Therefore, THF was chosen as the solvent of choice for the thiophosphorylation reaction. 
Table S8. Optimization of the reaction solvent using a catalytic amount of quinine.

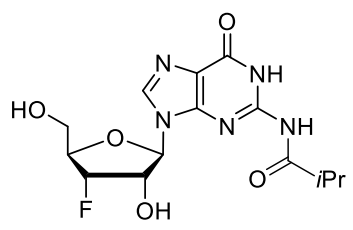

$1 \mathrm{a}$

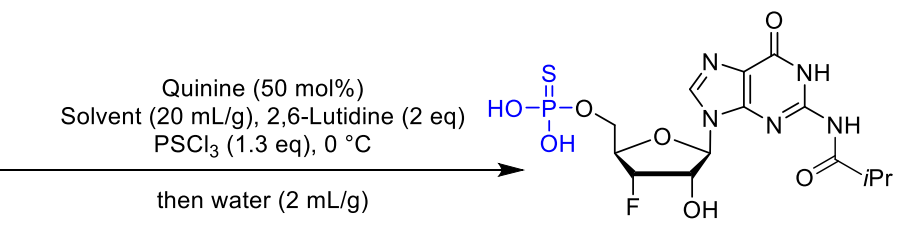

$1 \mathrm{~b}$

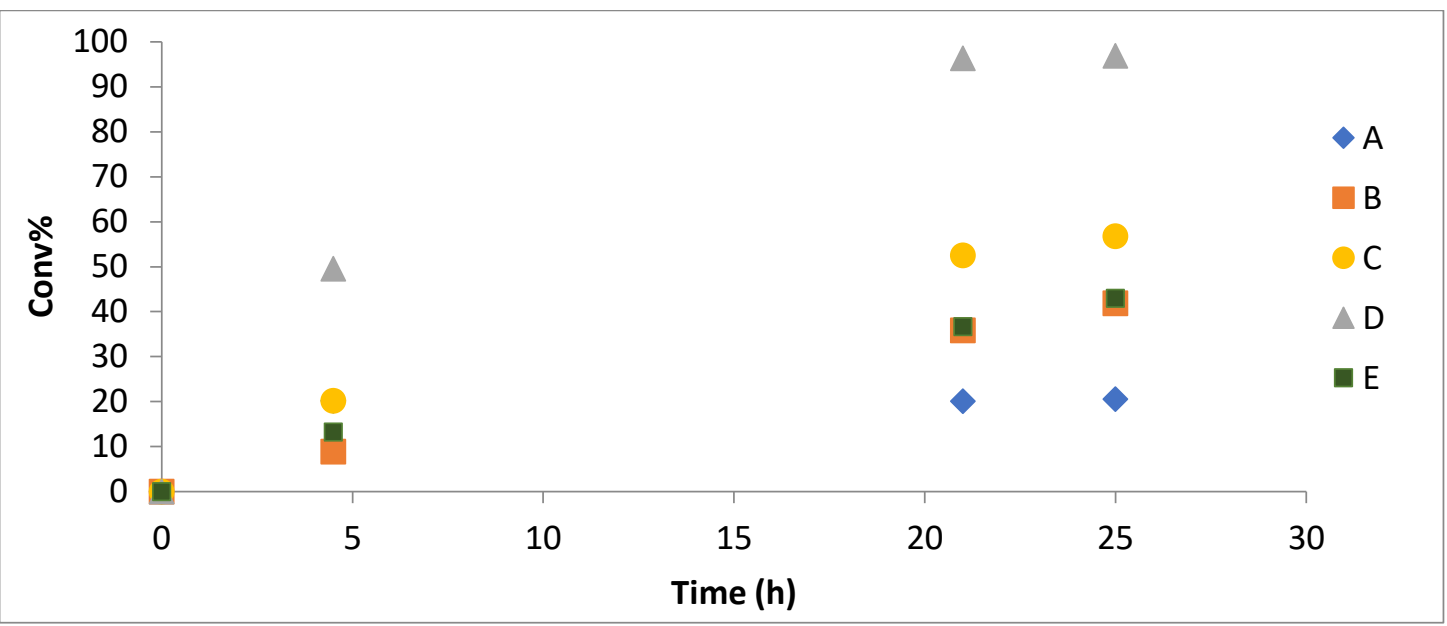

\begin{tabular}{cccc}
\hline Entry & Solvent & $\mathbf{( 1 b \% )}$ & Conv\% \\
\hline 1 & Acetone & 16.3 & 20.6 \\
2 & 2Me-THF & 33.0 & 41.9 \\
3 & EtOAc & 50.8 & 56.8 \\
4 & MeCN & 83.8 & 96.9 \\
5 & MIBK & 32.5 & 43.0 \\
\hline
\end{tabular}

2.6.3 Effects of salt additives. The role of various salt additives was investigated, such as $\mathrm{LiCl}, \mathrm{Na}_{2} \mathrm{CO}_{3}$, $\mathrm{NaOAc}, \mathrm{Li}_{2} \mathrm{CO}_{3}$, and $\mathrm{KOCOCF}_{3}$, to see the effect of counteranion on the quinine-catalyzed thiophosphorylation reaction, as shown in Table S9. The goal was to scavenge $\mathrm{HCl}$ when generated during the reaction by using various mild basic salt additives and see if the counteranion of any of the salts was important and gave better results. All these additives showed a worse performance, mainly due to poor reactivity and lower conversions. 
Table S9. Screening of salt additives using a catalytic amount of quinine.
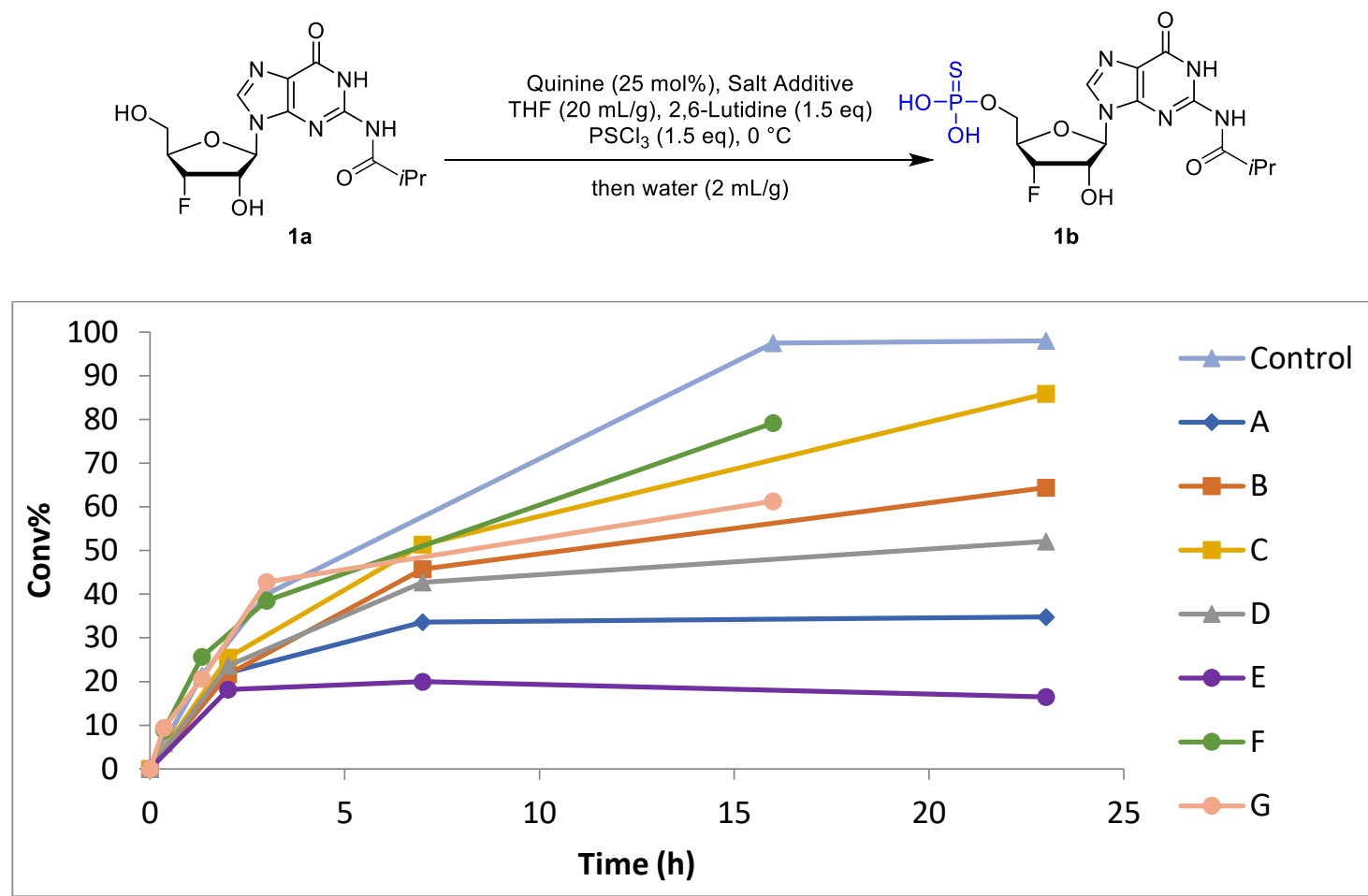

\begin{tabular}{cccc}
\hline Entry & Salt Additive & Salt additive (eq) & (1b\%) \\
\hline A & $\mathrm{Na}_{2} \mathrm{CO}_{3}$ & 1.0 & 22.4 \\
B & $\mathrm{NaOAc}$ & 1.0 & 58.6 \\
$\mathrm{C}$ & $\mathrm{Li}_{2} \mathrm{CO}_{3}$ & 1.0 & 78.8 \\
D & $\mathrm{LiOAC}$ & 1.0 & 43.2 \\
E & $\mathrm{KOCOCF}_{3}$ & 1.0 & 11 \\
F & $\mathrm{LiCl}_{6}$ & 0.5 & 70.2 \\
G & $\mathrm{LiCl}$ & 1.0 & 56.9 \\
\hline
\end{tabular}

\subsection{Role of quinine catalyst versus quinoline derivatives}

Various quinoline derivatives were tested to understand the role of quinine better. Table S10 shows a summary of this screening and highlights the importance of quinine as a multifunctional catalyst. Combination of 6-methoxyquinoline (2.0 equiv) and 2,6-lutidine led to $70.9 \% \mathbf{1 b}$, around $20 \%$ lower than the quinine-catalyzed thiophosphorylation reaction (entry 10). 
Table S10. Screening of quinolines for thiophosphorylation reaction.
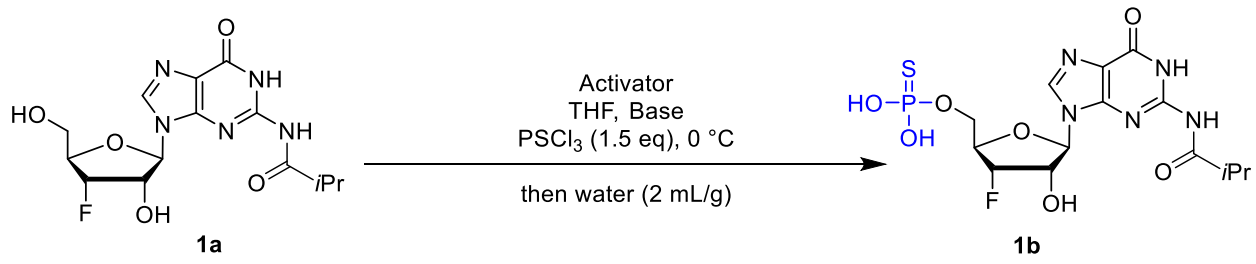

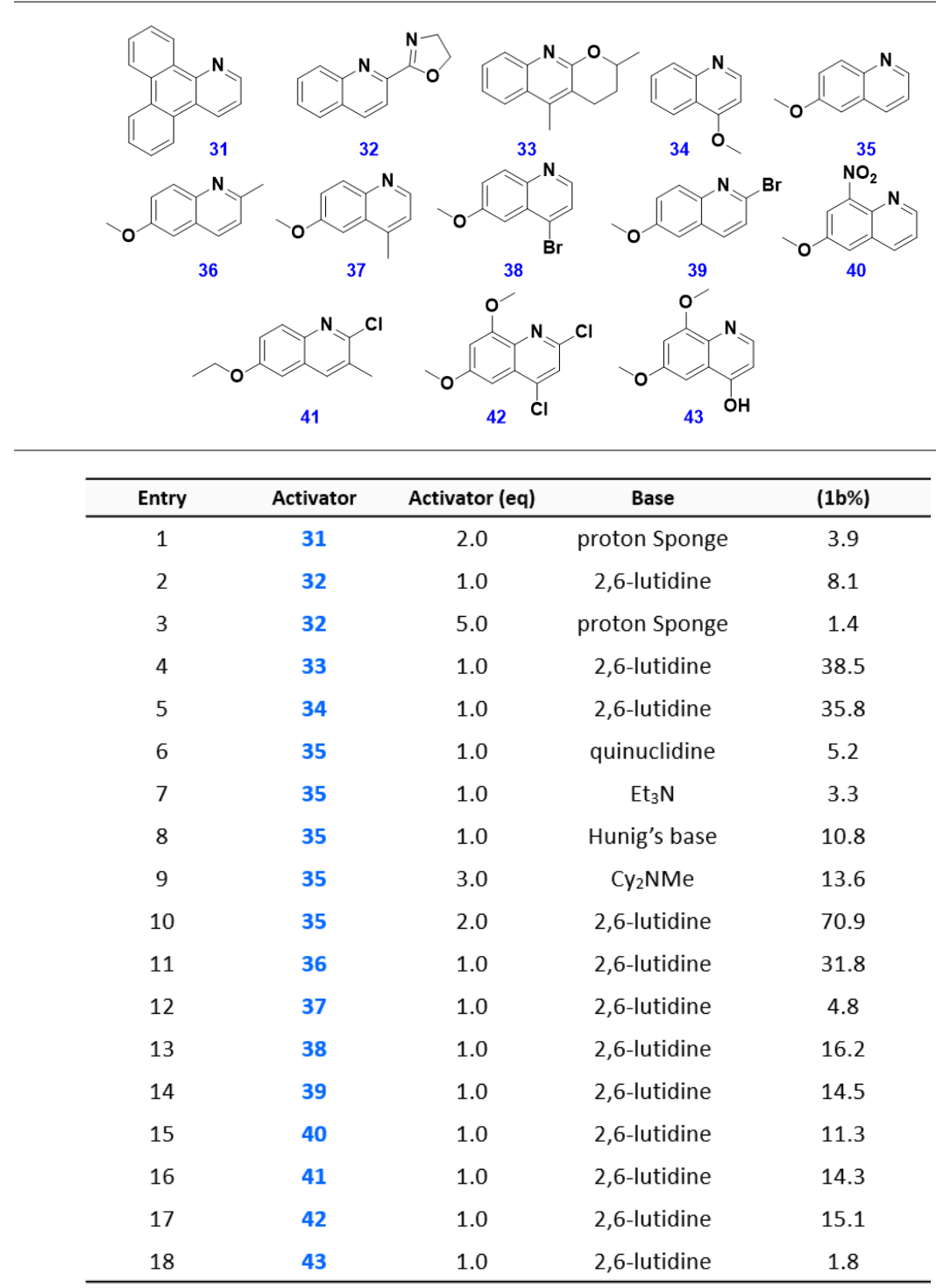

Various loadings of 6-methoxyquinoline were tested in combination with 2,6-lutidine, as shown in Table S11. Reaction conversion was improved upon increasing the equivalents of 6-methoxyquinoline to 2.0, but only $70 \%$ of the desired product $\mathbf{1 b}$ was formed. 
Table S11. Screening of different loadings of 6-methoxyquinoline for thiophosphorylation of $\mathbf{1 a}$.

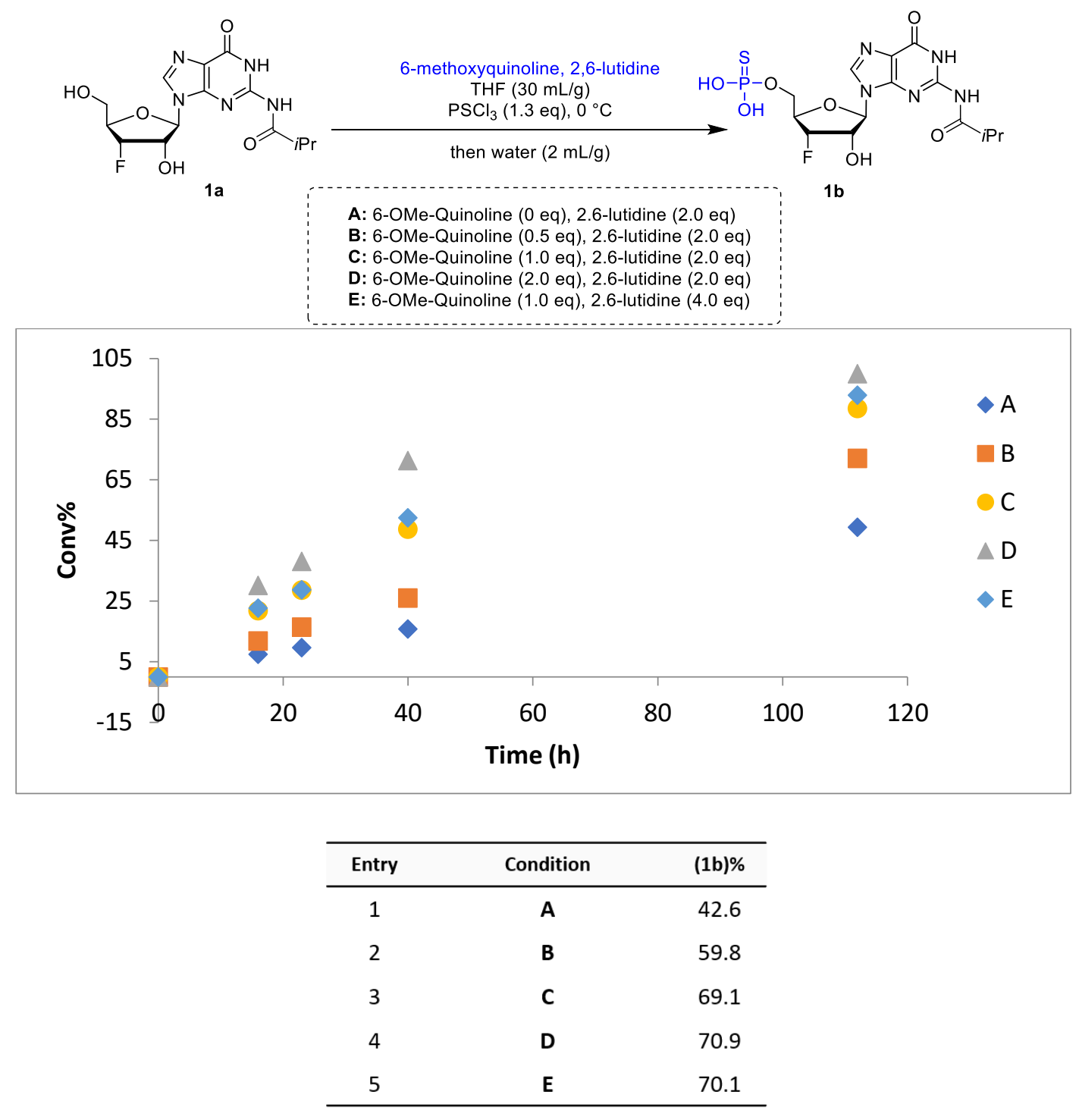

\subsection{Reaction performance and the importance of the chiral pocket}

Five experiments were performed in parallel to understand the significance of the quinine's chiral pocket (Table S12). The reactivity of quinine, 6-methoxyquinoline, and its pseudoenantiomer (quinidine) were significantly different. This data suggested a match-mismatch scenario with the quinidine/quinine pair with respect to the nucleoside, further supporting a specific recognition in the thiophosphorylation reaction. 
Table S12. Screening of different activators to understand the role of the chiral pocket.
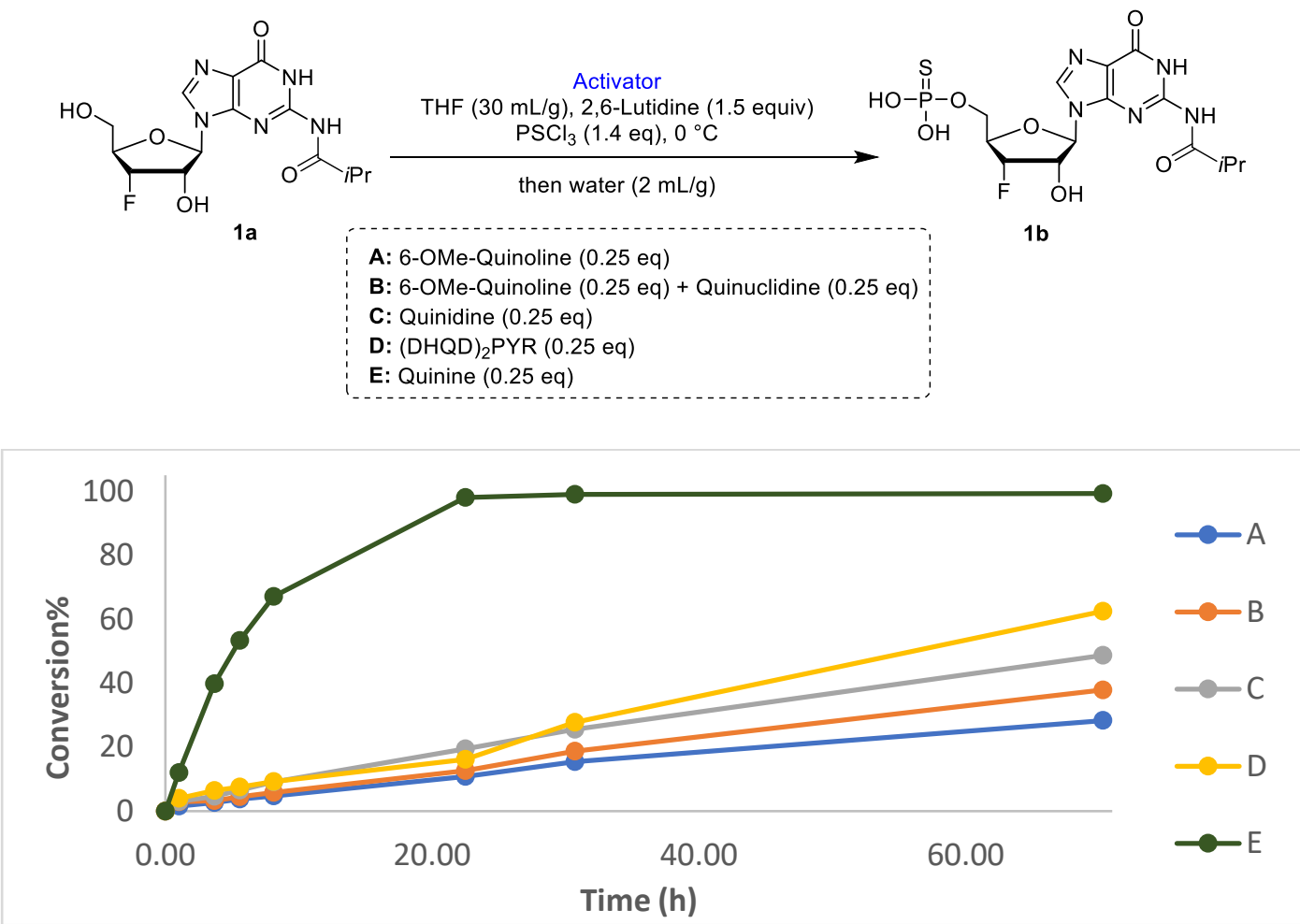

\begin{tabular}{cccccc}
\hline Entry & Condition & Age time (h) & $\mathbf{1 b} \%$ & $\mathbf{1 d \%}$ & $\mathbf{1 e} \%$ \\
\hline 1 & A & 6 & 2 & 0.2 & 0 \\
2 & B & 6 & 2 & 0.3 & 0.9 \\
3 & C & 6 & 5 & 0.2 & 0.1 \\
4 & D & 6 & 2 & 0.1 & 1.5 \\
5 & E & 6 & 52 & 0.1 & 0.8 \\
\hline 6 & A & 23 & 9 & 0.2 & 0.2 \\
7 & B & 23 & 10 & 0.4 & 1.1 \\
8 & C & 23 & 17 & 0.4 & 0.7 \\
9 & D & 23 & 13 & 0.1 & 2.0 \\
10 & E & 23 & 93 & 0.7 & 2.0 \\
\hline 11 & A & 70 & 26 & 1.7 & 0.8 \\
12 & B & 70 & 32 & 1.9 & 2.0 \\
13 & C & 70 & 40 & 1.4 & 2.1 \\
14 & D & 70 & 47 & 0.9 & 5.6 \\
15 & E & 70 & 92 & 0.9 & 3.0 \\
\hline
\end{tabular}




\section{Mechanistic studies}

\subsection{Reaction kinetic profiles}

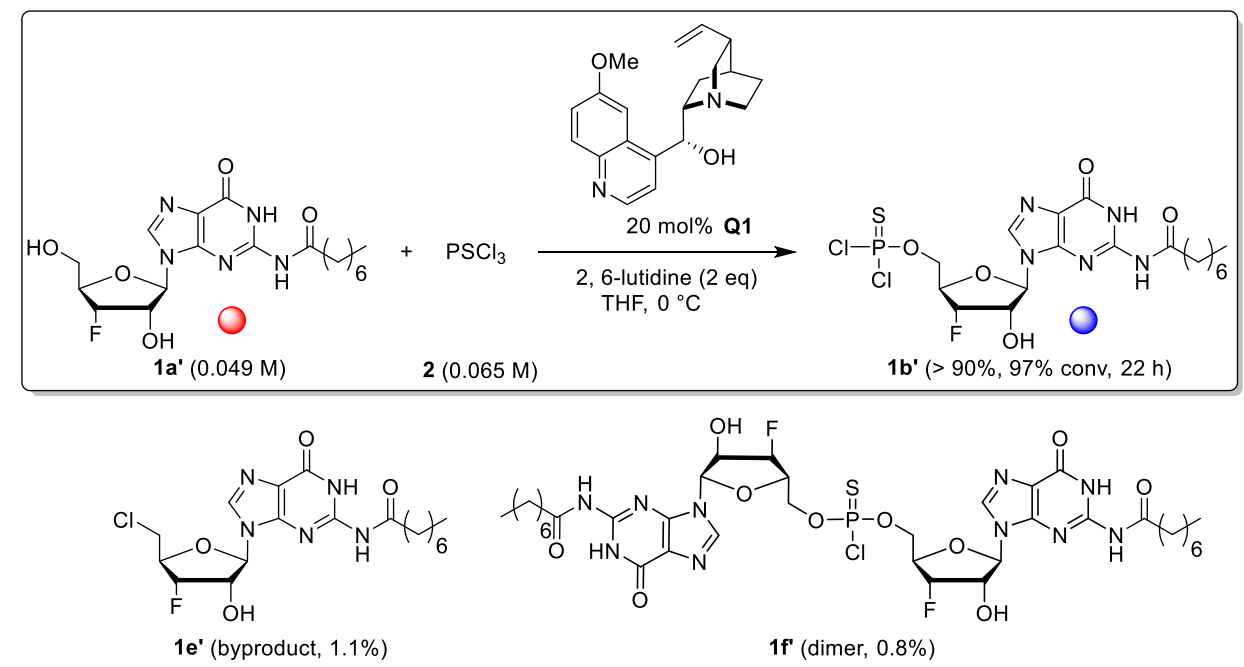

Scheme S4. Reaction scheme for mechanistic studies.

General procedure. Inside an $\mathrm{N}_{2}$-filled glovebox, a solution of nucleoside 1a' (200 mg), quinine (33 $\mathrm{mg}$ ), and 2,6-lutidine (115 $\mu \mathrm{L})$ in THF- $\mathrm{d}_{8}$ were prepared in a $10 \mathrm{~mL}$ volumetric flask. A $600 \mu \mathrm{L}$ aliquot from this solution was transferred into a $5 \mathrm{~mm}$ NMR tube that contained 2 to 3 beads of pre-activated molecular sieves ( $3 \AA$ ). The NMR tube was sealed with a screw cap and Parafilm ${ }^{\circledR} \mathrm{M}$ and the sample was brought out of the $\mathrm{N}_{2}$-filled glovebox. The reaction mixture was then cooled to $0{ }^{\circ} \mathrm{C}$ inside of the NMR spectrometer. The reaction was initiated by the addition of $4 \mu \mathrm{L}$ of neat $\mathrm{PSCl}_{3}$.

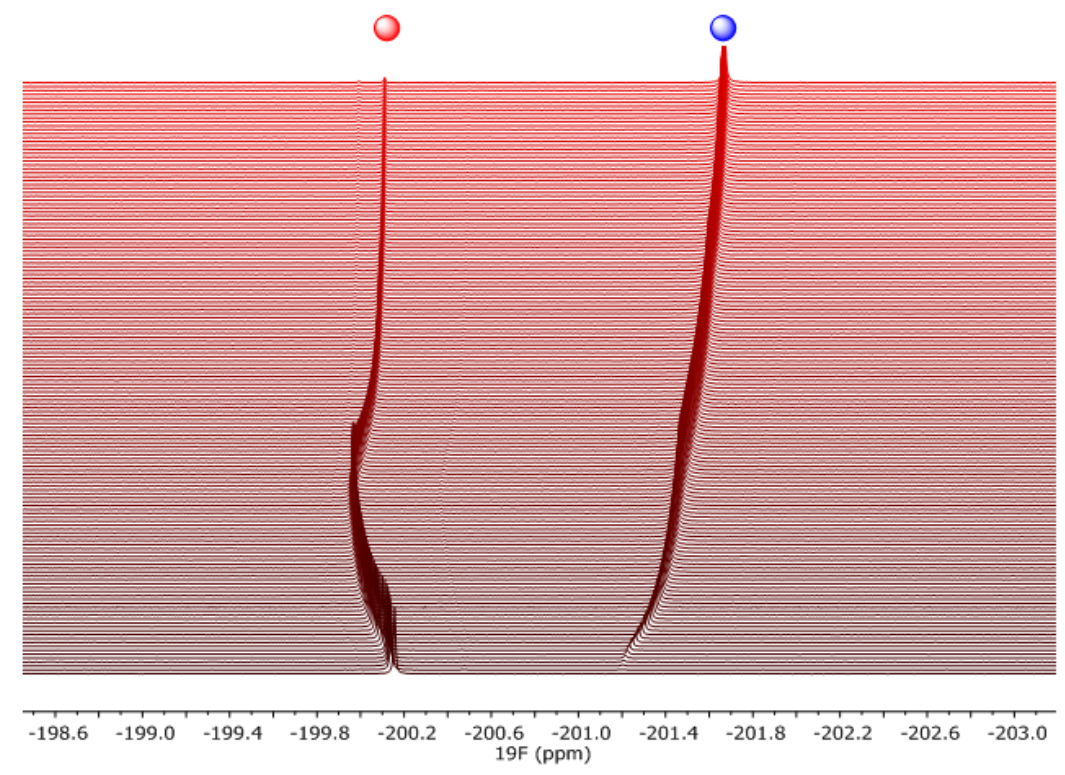


Figure S2. ${ }^{19} \mathrm{~F}$ NMR spectra overlaid in ca. 5 min intervals ( $T=0$ min on the bottom, $T=21.7 \mathrm{~h}$ at the top trace).

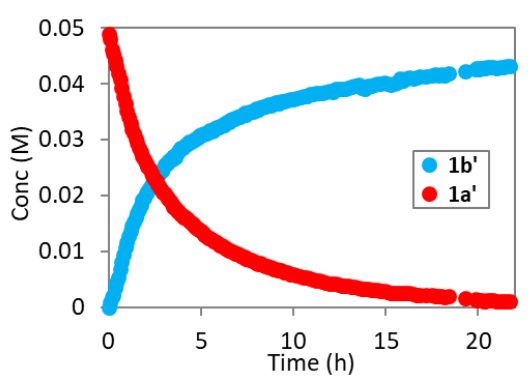

Figure S3. Temporal concentration profiles of $\mathbf{1 a}^{\prime}$ and $\mathbf{1} \mathbf{b}^{\prime}$ monitored by ${ }^{19} \mathrm{~F}$ NMR spectroscopy at $0{ }^{\circ} \mathrm{C}$ using $[1]_{\mathrm{o}}=0.049 \mathrm{M},\left[\mathrm{PSCl}_{3}\right]_{\mathrm{o}}=0.065 \mathrm{M},[2,6 \text {-lutidine }]_{\mathrm{o}}=0.098 \mathrm{M}$ and, $[\mathbf{Q 1}]_{\mathrm{T}}=0.0098 \mathrm{M}$ in anhydrous THF.

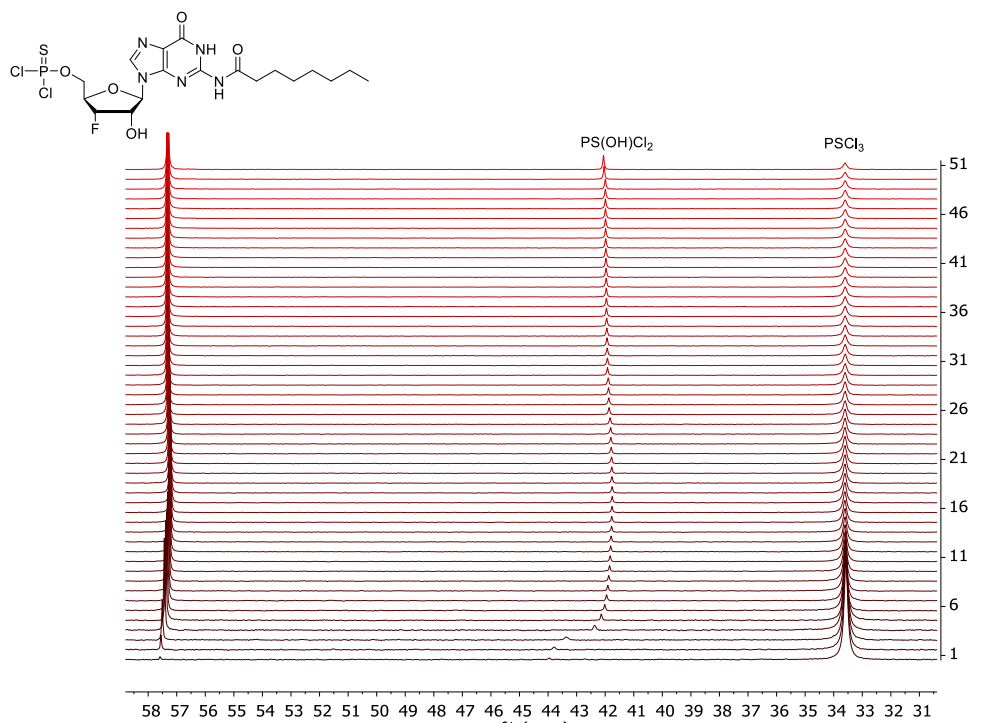

Figure S4. ${ }^{31} \mathrm{P}$ NMR spectra overlaid over the reaction course $(T=0 \mathrm{~min}$ on the bottom, $T=21.7 \mathrm{~h}$ at the top trace). 
By examining the reaction course via ${ }^{1} \mathrm{H}$ NMR spectroscopy, it was observed that the oxymethine proton at the $\mathrm{C}-9$ position of the quinine shifts rapidly from 5.5 to $6.6 \mathrm{ppm}$ upon the addition of $\mathrm{PSCl}_{3}$. This change in chemical shift was determined to result from a conformational change triggered by protonation of the quinuclidine moiety by $\mathrm{HCl}$ generated in situ as it was confirmed by overlaying the spectra with the quinine hydrochloride reference.
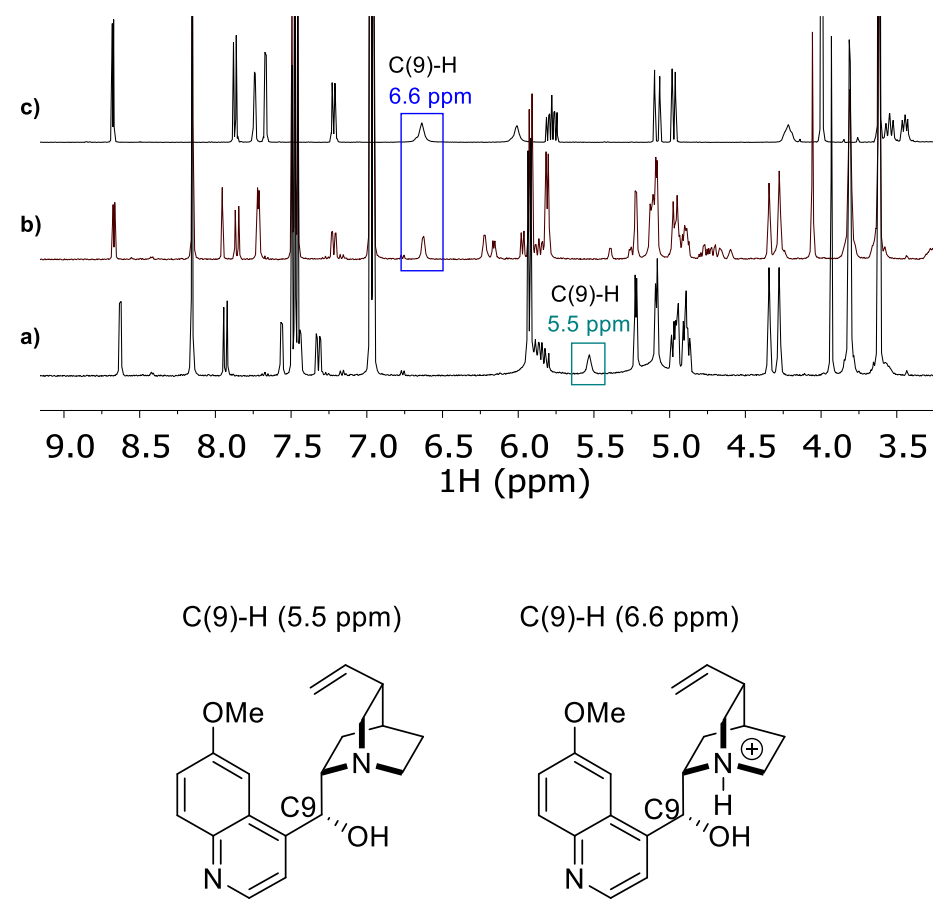

Figure S5. ${ }^{1} \mathrm{H}$ NMR spectroscopy of (a) the reaction mixture at $t=0 \mathrm{~min}$; (b) the reaction mixture after 10 minutes; c) quinine hydrochloride reference showing the $\mathrm{C}-9$ proton at $6.6 \mathrm{ppm}$. All spectra were recorded in THF- $d_{8}$ at $0{ }^{\circ} \mathrm{C}$. 


\subsection{Determination of the reaction orders of each reaction components}

Table S13. Experiments designed to extract reaction orders.

\begin{tabular}{|l|l|l|l|l|l|}
\cline { 2 - 6 } \multicolumn{1}{c|}{} & Exp a & Exp b & Exp c & Exp d & Exp e \\
\hline$[\mathbf{1}]_{\mathrm{O}}$ & 0.0490 & 0.0245 & 0.0245 & 0.0490 & 0.0490 \\
\hline$[\mathbf{2}]_{\mathrm{O}}$ & 0.0652 & 0.0652 & 0.0407 & 0.0652 & 0.0652 \\
\hline$[\mathbf{Q}]_{\mathrm{T}}$ & 0.0098 & 0.0098 & 0.0098 & 0.0049 & 0.0098 \\
\hline$[2,6-\text {-lutidine }]_{\mathrm{O}}$ & 0.0980 & 0.0980 & 0.0980 & 0.0980 & 0.0490 \\
\hline
\end{tabular}
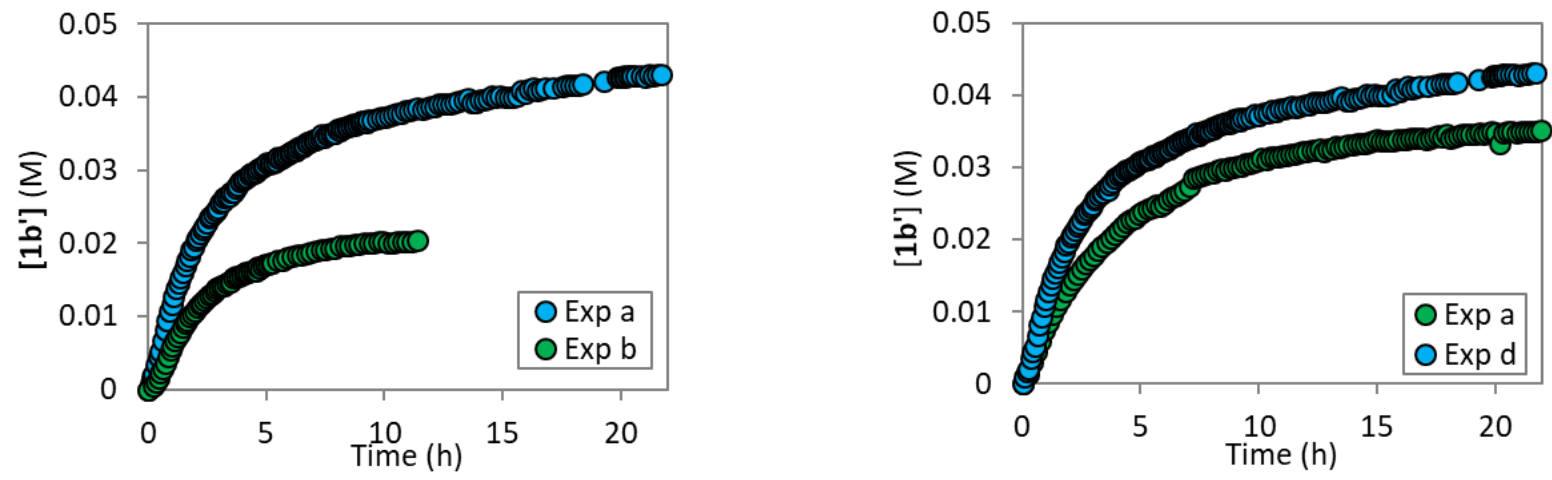

Figure S6. (Left) RPK illustrating positive order in the concentration of nucleoside starting material ([1a']). Reaction carried out using either $0.049 \mathrm{M}$ (exp a) or $0.0245 \mathrm{M}(\exp$ b) of 1a'. (Right) RPK illustrating positive order in $[\mathbf{Q 1}]_{\mathrm{T}}$. The reaction carried out using either $0.0098 \mathrm{M}(\exp$ a) or $0.0049 \mathrm{M}(\exp \mathrm{d})$ of quinine.
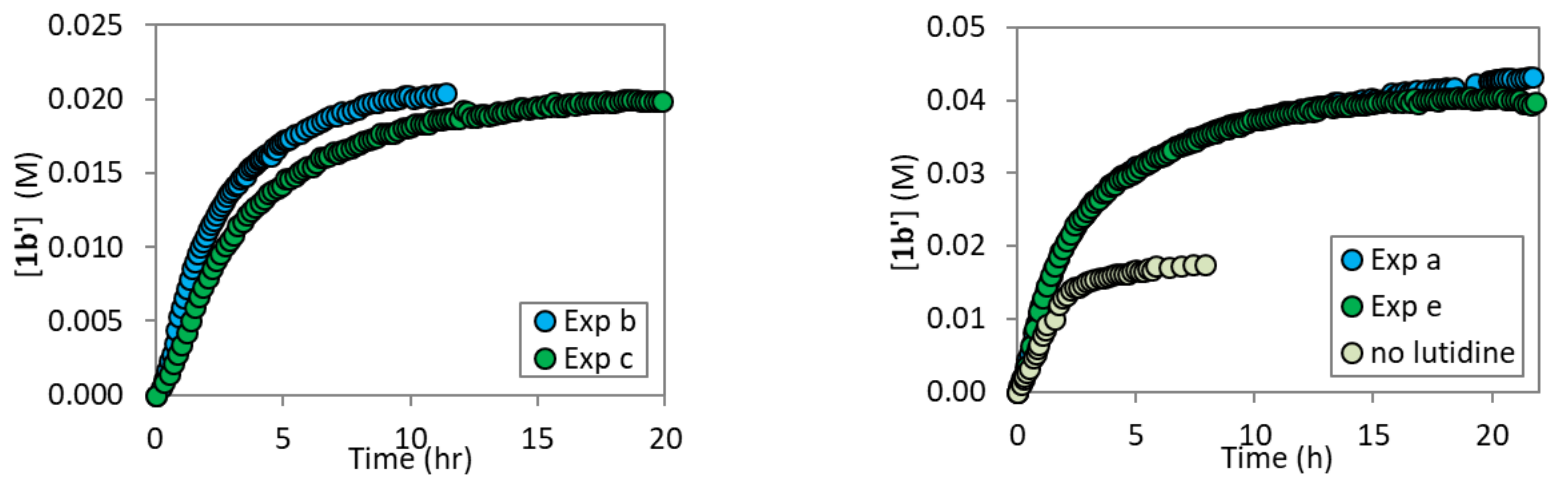

Figure S7. (Left) Graphical RPK illustrating positive order in [ $\left.\mathrm{PSCl}_{3}\right]$. Reaction carried out using either $0.0652 \mathrm{M}(\exp \mathrm{b})$ or $0.0407 \mathrm{M}$ (exp c) of $\mathrm{PSCl}_{3}$. (Right) Graphical RPK illustrating zero order in [2,6lutidine]. Reaction carried out using either $0.098 \mathrm{M}(\exp$ a), $0.049 \mathrm{M}$ (exp e), or $0 \mathrm{M}$ of 2,6-lutidine. 


\subsection{Kinetic profiles using different quinine derivatives}

$\mathrm{R}=\mathrm{H}, \mathrm{F}, \mathrm{Me}, \mathrm{OMe}$ (quinine)
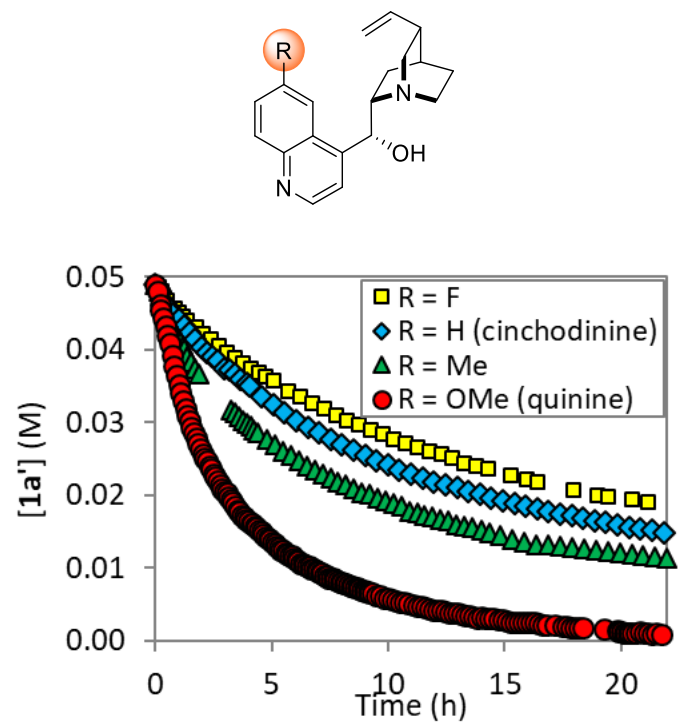
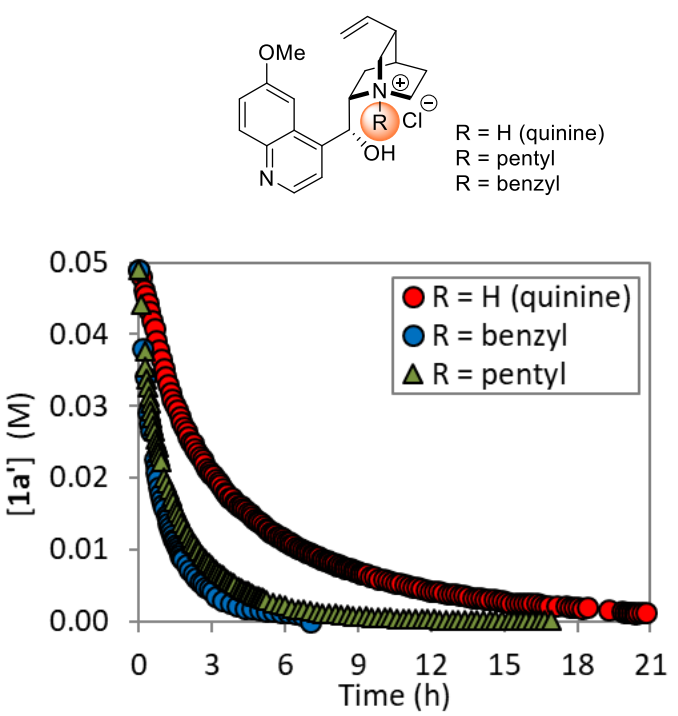

Figure S8. (Left) Graphical RPK illustrating the kinetic profiles when varying the aromatic substituent of the quinoline ring. (Right) Graphical RPK illustrating the rate comparison of quinine with its N-pentyl and benzyl derivatives.
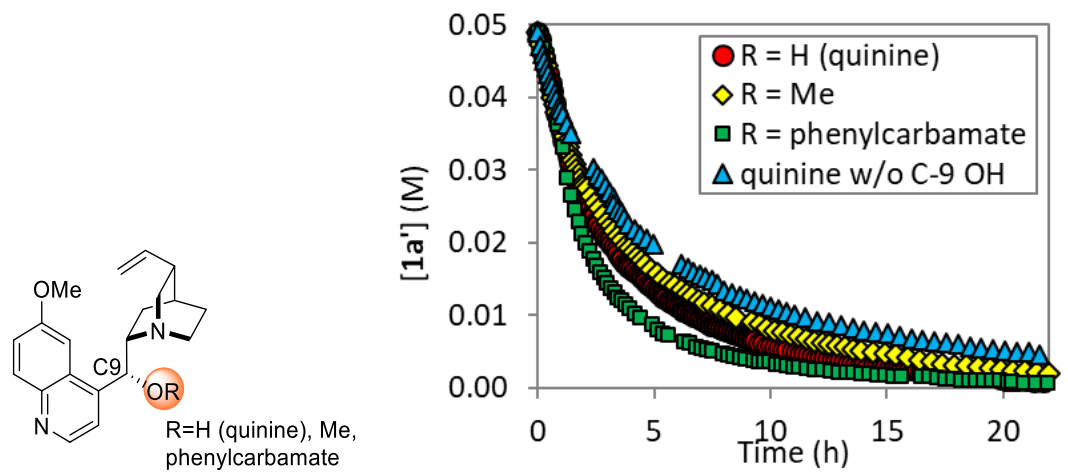

Figure S9. (Left) Graphical RPK illustrating the rate comparison of quinine with two C-9 alcohol protected derivatives and the analog in which C-9 alcohol is not present. 


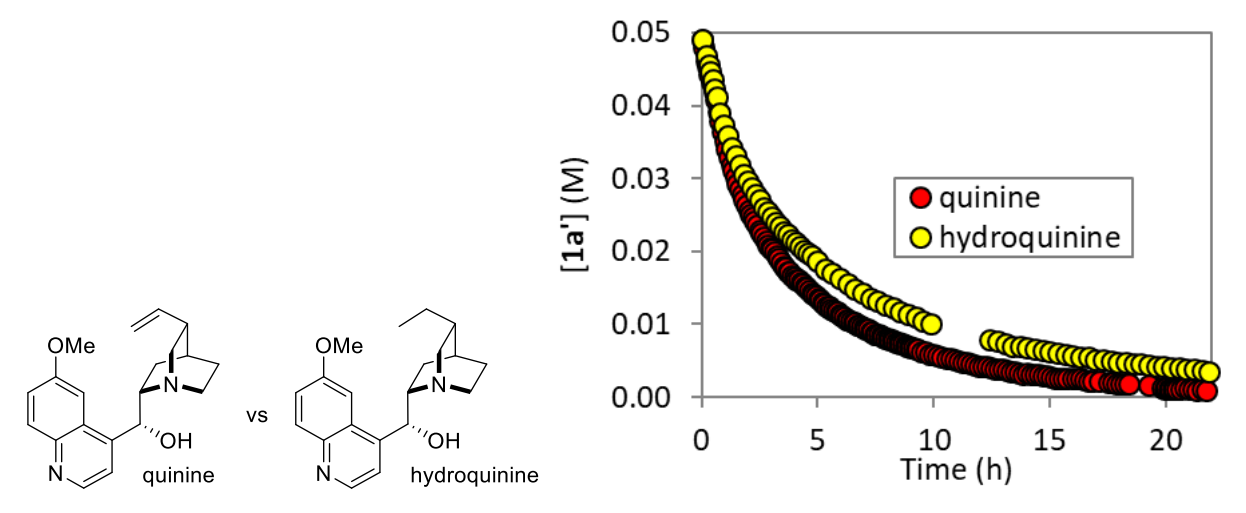

Figure S10. Graphical RPK illustrating the rate comparison of quinine with hydroquinine. (Right) Graphical RPK illustrating the rate comparison of quinine with 9-epi-quinine and quinuclidine.
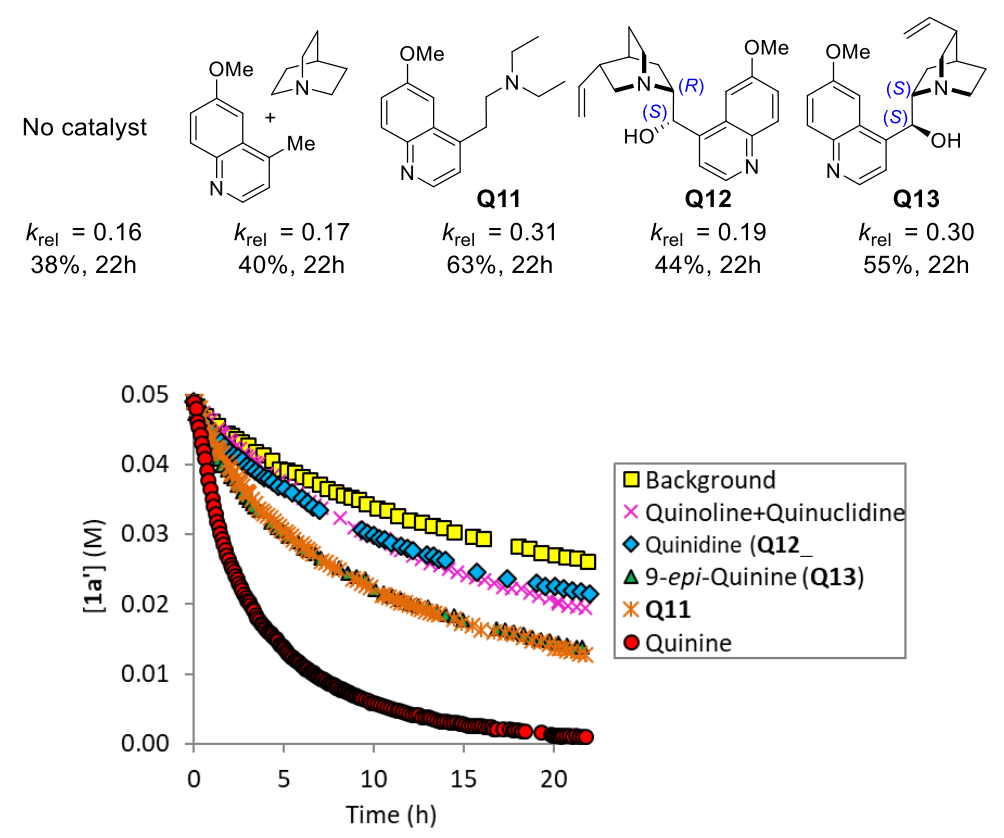

Figure S11. Temporal concentration profiles of 1a' monitored by 19F NMR spectroscopy using [1.' $]$ o = $0.049 \mathrm{M},[\mathrm{PSCl} 3] \mathrm{o}=0.065 \mathrm{M},[$ Lutidine $] \mathrm{o}=0.098 \mathrm{M}$, and [catalyst $] \mathrm{T}=0.0098$, where catalyst could be quinine, 9-epi-quinine, or quinuclidine. All reactions were carried out under standard conditions in anhydrous THF-d8 at $0{ }^{\circ} \mathrm{C}$.

3.4 Catalyst robustness. We also performed graphical manipulation of the two same excess experiments (experiments "a" and "c" from Table S13, excess $=0.0162 \mathrm{M}$ ) to examine the catalyst robustness (Figure S12). As shown by the green arrows, the concentration of nucleoside (1a') and thiophosphorylating agent (2) at the beginning of the experiment "c" (green circles) are identical to those of the experiment "a" (red circles) after ca. $2.2 \mathrm{~h}$ of reaction. A comparison of these two reactions' profiles is then possible by shifting the curve from reaction $\mathrm{c}$ to the appropriate time on the $\mathrm{x}$-axis. The perfect 
overlay of the "time adjusted" kinetic profiles suggests the high stability of the catalyst over the course of the reaction. Furthermore, since experiment "a" contains 50\% of the reaction product at the time adjusted point, the fact that it still proceeds at the same rate as experiment "c" from that point onward rules out the existence of product inhibition in the reaction.

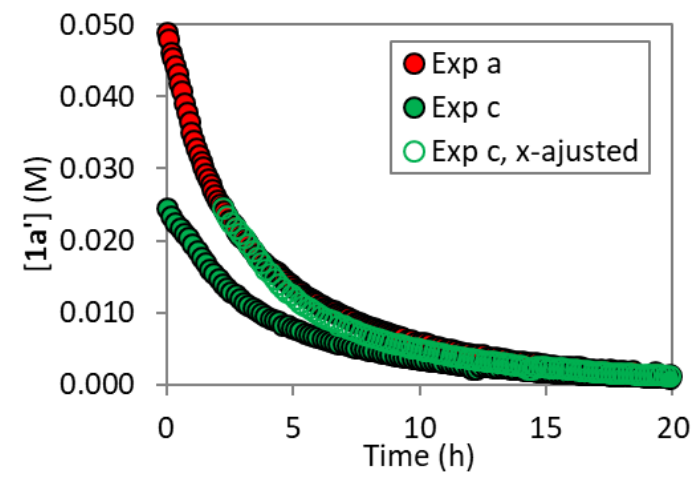

Figure S12. Temporal concentration profiles of 1a' for two same excess experiments (experiments "a" and "c" from Table S13, excess $=0.0162 \mathrm{M}$ ) monitored by ${ }^{19} \mathrm{~F}$ NMR spectroscopy to examine the catalyst robustness. All reactions were carried out in anhydrous THF at $0{ }^{\circ} \mathrm{C}$.

\subsection{KIE experiment}

A positive KIE of 1.7 was obtained using a substrate with deuterated hydroxyl groups at both the C5' and $\mathrm{C} 2$ ' positions of the nucleoside:

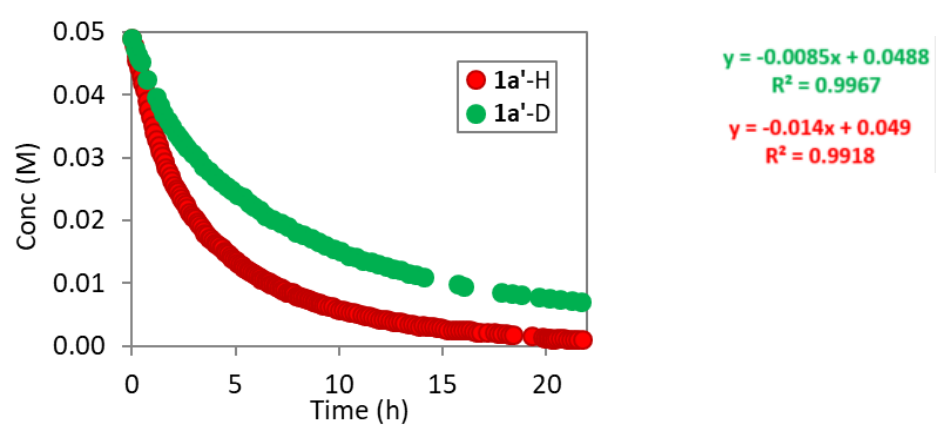

$$
\mathrm{KIE}=\frac{\text { Rate } 1 \cdot \mathrm{CH}_{2}}{\text { Rate } 1 \cdot \mathrm{CD}_{2}}=\frac{0.014}{0.0085}=1.7
$$

Figure S13. Temporal concentration profiles of $1 \mathbf{a}^{\prime}-\mathbf{H}$ and $\mathbf{1 a}^{\prime}-\mathbf{D}$ monitored by ${ }^{19} \mathrm{~F}$ NMR spectroscopy using $\left[\mathbf{1 a}^{\prime}-\mathbf{H}\right]_{\mathrm{o}}=0.049 \mathrm{M}$ or $\left[\mathbf{1 a}^{\prime}-\mathbf{D}\right]_{\mathrm{o}}=0.049 \mathrm{M},\left[\mathrm{PSCl}_{3}\right]_{\mathrm{o}}=0.065 \mathrm{M},[\text { Lutidine }]_{\mathrm{o}}=0.098 \mathrm{M}$, and [Quinine $]_{\mathrm{T}}$ $=0.0098 \mathrm{M}$. All reactions were carried out under standard conditions in anhydrous THF- $d_{8}$ at $0{ }^{\circ} \mathrm{C}$. 


\section{General UPLC methods}

4.1 Short UPLC method - used to monitor thiophosphorylation reaction of nucleosides

Column:

Ascentis Express C18 HPLC Column $10 \mathrm{~cm} \times 3.0 \mathrm{~mm}, 2.7 \mu \mathrm{m}$ (Cat\#53814-U)

Mobile phase A:

HPLC grade acetonitrile

Mobile phase B:

$10 \mathrm{mM} \mathrm{NH}_{4} \mathrm{HCO}_{3}$ in HPLC grade water

Gradient:

Time $\% \mathrm{~A} \quad \% \mathrm{~B}$

$0.0 \quad 5 \quad 95$

$5.0 \quad 95 \quad 5$

$5.1 \quad 5 \quad 95$

$\begin{array}{lll}6.5 & 5 & 95\end{array}$

Run time:

$6.50 \mathrm{~min}$

Post run

$1 \mathrm{~min}$

Flow rate:

$0.8 \mathrm{~mL} \mathrm{~min}^{-1}$

Detection:

$260 \mathrm{~nm}$

Temperature: $\quad 40{ }^{\circ} \mathrm{C}$

Injection: $\quad 0.5-1 \mu \mathrm{L}$

\begin{tabular}{ll} 
Identity & $\mathbf{R}_{\mathbf{t}}(\mathbf{m i n})$ \\
\hline 1a substrate & 2.45 \\
1b product & 1.01 \\
Impurity 1 (1d) & 0.45 \\
Impurity 2 (1e) & 2.78 \\
2,6-Lutidine & 3.01 \\
quinine (Q1) & 3.85
\end{tabular}

\subsection{Long UPLC method 1 used to monitor thiophosphorylation reaction of highly polar nucleosides}

Column:

Atlantis T3 column, $100 \AA$ A, $4.6 \mathrm{~mm} \times 150 \mathrm{~mm}($ Cat \# 50-781-992)

Mobile phase A:

HPLC grade acetonitrile

Mobile phase B:

$50 \mathrm{mM} \mathrm{NH} \mathrm{HCO}_{3}$ in HPLC grade water

Gradient:

Time \% $\%$ B

$\begin{array}{lll}0 & 0 & 100\end{array}$

$\begin{array}{lll}10 & 10 & 90\end{array}$

$\begin{array}{lll}12 & 90 & 10\end{array}$

$\begin{array}{lll}14 & 90 & 10\end{array}$

$\begin{array}{lll}14.1 & 0 & 100\end{array}$

$\begin{array}{lll}17 & 0 & 100\end{array}$

Run time: $\quad 17 \mathrm{~min}$

Post run -

Flow rate: $\quad 1.0 \mathrm{~mL} \mathrm{~min}^{-1}$

Detection: $\quad 260 \mathrm{~nm}$ and $280 \mathrm{~nm}$

Temperature: $\quad 25^{\circ} \mathrm{C}$

Injection: $\quad 1 \mu \mathrm{L}$ 


\subsection{Long HPLC method 2 for monitoring the thiophosphorylation of highly polar nucleosides}

$\underline{\text { Chromatographic Conditions }}$

\begin{tabular}{|c|c|c|}
\hline Column: & \multicolumn{2}{|c|}{ Atlantis T3 $(150 \times 4.6 \mathrm{~mm}, 3 \mu \mathrm{m})$ or equivalent } \\
\hline Detector: & \multicolumn{2}{|c|}{$\mathrm{UV}$ at $260 \mathrm{~nm}$} \\
\hline Temperature: & \multicolumn{2}{|l|}{$25^{\circ} \mathrm{C}$} \\
\hline Flow rate: & \multicolumn{2}{|l|}{$1 \mathrm{~mL} / \mathrm{min}$} \\
\hline Injection Volume: & \multicolumn{2}{|l|}{$3 \mu \mathrm{L}$} \\
\hline Sample Tray Temperature: & \multicolumn{2}{|l|}{ Ambient } \\
\hline \multirow[t]{2}{*}{ Stock Buffer Solution: } & \multicolumn{2}{|c|}{$\begin{array}{l}\text { Mobile Phase A: } 50 \mathrm{mM} \text { ammonium bicarbonate }(\mathrm{pH} \sim 8.2) \text {, } \\
\text { accurately transfer } 3.95 \mathrm{~g} \text { of ammonium bicarbonate into } 1 \mathrm{~L} \\
\text { purified HPLC water and mix well. }\end{array}$} \\
\hline & \multicolumn{2}{|c|}{ Mobile Phase B: MeCN } \\
\hline \multirow[t]{6}{*}{ Mobile Phase Program: } & Time (min) & $\% \mathrm{~B}$ \\
\hline & 0 & 0 \\
\hline & 10 & 10 \\
\hline & 15 & 90 \\
\hline & 20 & 90 \\
\hline & 20.1 & 0 \\
\hline
\end{tabular}

Post Time: $5 \mathrm{~min}$ 


\section{Quinine derivatives: Synthesis and characterization data}

(1S,2S,4S,5R)-2-((R)-methoxy(6-methoxyquinolin-4-yl)methyl)-5-vinylquinuclidine, Q3

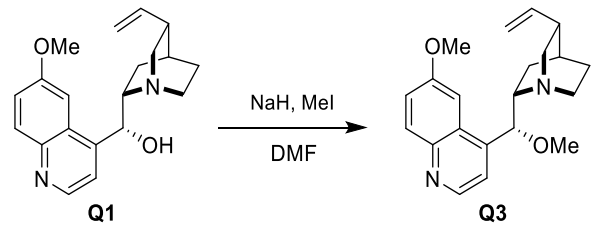

Quinine (Q1) (30 g, $90 \mathrm{mmol}, 1.0 \mathrm{eq}$ ) was added into the DMF (200 mL). The reaction solution was cooled to $0^{\circ} \mathrm{C}$, and $\mathrm{NaH}(2.7 \mathrm{~g}, 112 \mathrm{mmol}, 1.22 \mathrm{eq})$ was added into the reaction and stirred at $0{ }^{\circ} \mathrm{C}$ for $1 \mathrm{~h}$. Then to the reaction suspension was added MeI (14.4 g, $101 \mathrm{mmol}, 1.09 \mathrm{eq})$ in DMF (50 mL) dropwise and the mixture was stirred at $30^{\circ} \mathrm{C}$ for $2 \mathrm{~h}$. Analysis by LCMS indicated $\sim 0 \%$ of $\mathbf{Q 1}$ remained, and $\sim 99 \%$ of the desired mass $(\mathbf{Q 3})$ was detected. The reaction mixture was quenched with ice water $(1 \mathrm{~L})$ and extracted with AcOEt (500 mL x 3). The organic phase was dried $\left(\mathrm{Na}_{2} \mathrm{SO}_{4}\right)$, filtered, and concentrated in vacuum to give the crude. Compound Q3 was purified by reversed-phase flash chromatography (Column: Welch Ultimate XB_C18 32*210 mm 20/40 $\mu \mathrm{m} ; 120 \AA$ A. Mobile phase: [water( $\left(0.1 \% \mathrm{NH}_{3} \mathrm{H}_{2} 0\right)$ :acetonitrile]. Gradient B\%: 0\%-50\%, $15 \mathrm{~min}$; 50\%, 5 min. Instrument: TELEDYNE ISCO CombiFlashRf150). No enantiomeric erosions in final solid as confirmed by SFC method (Column: Chiralcel OD-3 50×4.6 mm I.D., $3 \mu \mathrm{m}$. Mobile phase: methanol (0.05\% DEA) in $\mathrm{CO}_{2}$ from $5 \%$ to $40 \%$. Flow rate: $3 \mathrm{~mL} / \mathrm{min}$. Wavelength: $220 \mathrm{~nm}$ ). Compound $\mathbf{Q 3}$ was obtained as a brown oil in 34\% isolated yield.

${ }^{1} \mathrm{H}$ NMR $\left(500 \mathrm{MHz}, \mathrm{CDCl}_{3}\right): \delta(\mathrm{ppm}) 8.76(\mathrm{~d}, J=4.5 \mathrm{~Hz}, 1 \mathrm{H}), 8.04(\mathrm{~d}, J=9.2 \mathrm{~Hz}, 1 \mathrm{H}), 7.42(\mathrm{~d}, J=4.5$ $\mathrm{Hz}, 1 \mathrm{H}), 7.37$ (dd, $J=9.2,2.7 \mathrm{~Hz}, 1 \mathrm{H}), 7.31(\mathrm{br}, 1 \mathrm{H}), 5.72(\mathrm{ddd}, J=17.6,10.3,7.7 \mathrm{~Hz}, 1 \mathrm{H}), 4.99-4.85$ (m, 3H), $3.93(\mathrm{~s}, 3 \mathrm{H}), 3.47-3.35(\mathrm{~m}, 1 \mathrm{H}), 3.30(\mathrm{~s}, 3 \mathrm{H}), 3.16-3.02(\mathrm{~m}, 2 \mathrm{H}), 2.74-2.65(\mathrm{~m}, 1 \mathrm{H}), 2.64-$ 2.59 (m, 1H), 2.25 (br, 1H), $1.80-1.69(\mathrm{~m}, 3 \mathrm{H}), 1.58-1.47(\mathrm{~m}, 2 \mathrm{H}) .{ }^{13} \mathrm{C} \mathrm{NMR}\left(126 \mathrm{MHz}, \mathrm{CDCl}_{3}\right): \delta$ (ppm) 157.7, 147.7, 144.7, 144.7, 142.1, 131.9, 127.5, 121.6, 118.8, 114.2, 101.3, 60.1, 57.3, 57.1, 55.7, 43.2, 40.2, 27.9, 27.8. HRMS(m/z): $[\mathrm{M}+\mathrm{H}]^{+}$calcd for $\left[\mathrm{C}_{21} \mathrm{H}_{27} \mathrm{~N}_{2} \mathrm{O}_{2}\right]$ 339.2067; found 339.2059.

(R)-(6-methoxyquinolin-4-yl)((1S,2S,4S,5R)-5-vinylquinuclidin-2-yl)methyl phenylcarbamate, $Q 4$

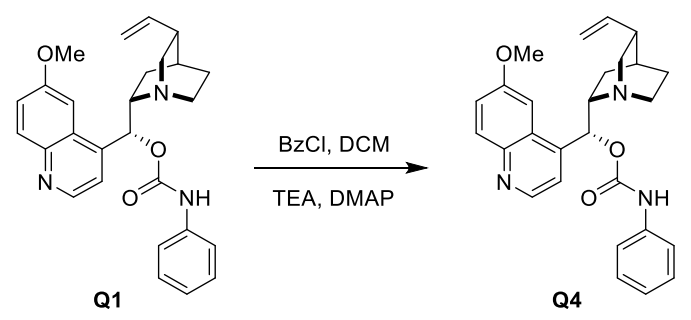


Quinine (Q1) (10 g, $1.2 \mathrm{~mol}, 1.0 \mathrm{eq})$ was added to the DCM (100 mL). Next, BzCl (4.48 g, $32 \mathrm{mmol}, 1.03$ eq), TEA (6.25 g, $64 \mathrm{mmol}, 2.0 \mathrm{eq})$, and DMAP (1.8 g, $15 \mathrm{mmol}, 0.48 \mathrm{eq})$ were added to the solution and stirred at $30{ }^{\circ} \mathrm{C}$ for $10 \mathrm{~h}$. Analysis by LCMS indicated $\sim 5.9 \%$ of Q1 was remained, and $~ 92.9 \%$ of the desired mass $\mathbf{Q 4}$ was detected. The reaction was diluted with $\mathrm{H}_{2} \mathrm{O}(100 \mathrm{~mL})$ and extracted with DCM (100 $\mathrm{mL})$. The organic phase was dried $\left(\mathrm{Na}_{2} \mathrm{SO}_{4}\right)$, filtered, and concentrated in vacuum to give the crude product. The crude was purified by silica gel chromatography (Petroleum ether/AcOEt $=50: 1$ to $0: 1$ ) to provide the product Q4 as a white solid in 83\% isolated yield. No erosions in ee were observed as confirmed by SFC method (Chiralcel OD-3 50×4.6 mm I.D., $3 \mu \mathrm{m}$. Mobile phase: methanol (0.05\% DEA) in $\mathrm{CO}_{2}$ from $5 \%$ to 40\%. Flow rate: $3 \mathrm{~mL} / \mathrm{min}$. Wavelength: $220 \mathrm{~nm}$ ).

${ }^{1} \mathrm{H}$ NMR (500 MHz, $\left.\mathrm{CDCl}_{3}\right): \delta(\mathrm{ppm}) 8.72(\mathrm{~s}, 1 \mathrm{H}), 8.01(\mathrm{~d}, J=9.2 \mathrm{~Hz}, 1 \mathrm{H}), 7.50(\mathrm{~s}, 2 \mathrm{H}), 7.42$ - $7.22(\mathrm{~m}$, 5H), $7.05(\mathrm{~s}, 1 \mathrm{H}), 6.57$ (d, $J=7.3 \mathrm{~Hz}, 1 \mathrm{H}), 5.83$ (dt, $J=17.5,8.6 \mathrm{~Hz}, 1 \mathrm{H}), 5.14-4.93(\mathrm{~m}, 2 \mathrm{H}), 3.95$ (s, $3 \mathrm{H}), 3.33-3.30(\mathrm{~m}, 1 \mathrm{H}), 3.20-2.98(\mathrm{~m}, 3 \mathrm{H}), 2.65(\mathrm{t}, J=12.3 \mathrm{~Hz}, 2 \mathrm{H}), 2.27$ (br, 1H), $1.95-1.45(\mathrm{~m}, 5 \mathrm{H})$. ${ }^{13} \mathrm{C}$ NMR (126 MHz, $\mathrm{CDCl}_{3}$ ): $\delta$ (ppm) 158.0, 152.7, 147.3, 144.6, 143.7, 141.6, 137.5, 131.6, 129.0, 127.2, 123.7, 121.9, 118.8, 118.6, 114.6, 101.5, 73.7, 59.0, 56.3, 55.7, 42.4, 39.5, 27.6, 27.4, 24.2. HRMS(m/z): $[\mathrm{M}+\mathrm{H}]^{+}$calcd for $\left[\mathrm{C}_{27} \mathrm{H}_{30} \mathrm{~N}_{3} \mathrm{O}_{3}\right]$ 444.2282; found 444.2270.

\section{(1S,2S,4S,5R)-2-((6-methoxyquinolin-4-yl)methyl)-5-vinylquinuclidine, Q5}

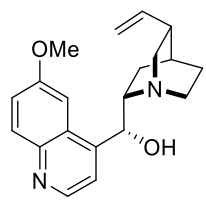

Q1

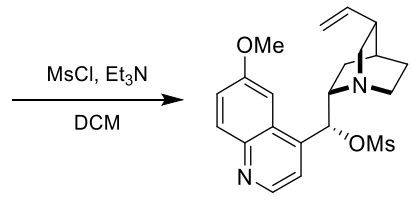

I

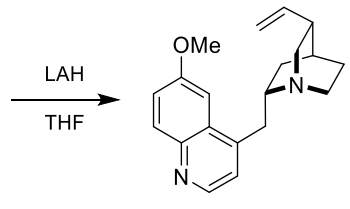

Q5

Quinine (Q1) (30 g, $93 \mathrm{mmol}, 1.0 \mathrm{eq})$ was added into the DCM $(400 \mathrm{~mL})$ and then cooled to $0^{\circ} \mathrm{C} . \mathrm{MsCl}$ $(21.16 \mathrm{~g}, 185 \mathrm{mmol}, 2 \mathrm{eq})$ and TEA $(23.26 \mathrm{~g}, 0.230 \mathrm{mmol}, 2.49 \mathrm{eq})$ were added into the solution at $0^{\circ} \mathrm{C}$ and stirred for $2 \mathrm{~h}$. Next, the reaction suspension was warmed to $30^{\circ} \mathrm{C}$ and stirred for $2 \mathrm{~h}$. TLC (Petroleum Ether/AcOEt = 1:1) indicated that $\mathbf{Q 1}$ was consumed, and a new major spot was detected. The reaction was diluted with $\mathrm{H}_{2} \mathrm{O}(200 \mathrm{~mL})$ and extracted with DCM $(100 \mathrm{~mL})$. The organic phase was dried $\left(\mathrm{MgSO}_{4}\right)$, filtered, and concentrated in vacuum to give the crude product I. The crude was purified by silica gel chromatography ( $\mathrm{DCM} / \mathrm{MeOH}=20: 1$ to $10: 1)$ to give the product $\mathbf{I}$ in $48 \%$ isolated yield as a yellow oil. ${ }^{1} \mathrm{HNMR}\left(400 \mathrm{MHz}, \mathrm{CDCl}_{3}\right)$ \&: $8.74(\mathrm{~d}, J=4.4 \mathrm{~Hz}, 1 \mathrm{H}), 8.00(\mathrm{~d}, J=7.2 \mathrm{~Hz}, 1 \mathrm{H}), 7.38-7.30$ (m, 3H), 6.09 (s, 1H), 5.79-5.72 (m, 1H), 4.97-4.92 (m, 2H), $3.90(\mathrm{~s}, 3 \mathrm{H}), 3.41(\mathrm{~s}, 1 \mathrm{H}), 3.35(\mathrm{~s}, 1 \mathrm{H}), 2.94-2.88(\mathrm{~m}, 1 \mathrm{H})$, 2.57-2.54 (m, 5H), $2.21(\mathrm{~s}, 1 \mathrm{H}), 1.97(\mathrm{~s}, 1 \mathrm{H}), 1.85-1.60(\mathrm{~m}, 5 \mathrm{H}), 1.50(\mathrm{t}, 1 \mathrm{H})$.

For step 2, LAH (1.5 g, $40 \mathrm{mmol}, 0.92 \mathrm{eq})$ was added into the THF (150 mL). The reaction was degassed with $\mathrm{N}_{2}$ for 3 times and cooled to $-78{ }^{\circ} \mathrm{C}$. Compound $\mathbf{I}(17.2 \mathrm{~g}, 43 \mathrm{mmol}, 1 \mathrm{eq})$ in THF $(100 \mathrm{~mL})$ was added 
to the LAH/THF mixture dropwise at $-78{ }^{\circ} \mathrm{C}$ and stirred for $1 \mathrm{~h}$. Then the reaction suspension was warmed to $10^{\circ} \mathrm{C}$ and stirred for $4 \mathrm{~h}$. LCMS analysis indicated compound I was consumed, and $\sim 44 \%$ of the desired mass was detected. The reaction solution was quenched with sat. aq. $\mathrm{NaHCO}_{3}(300 \mathrm{~mL})$, and a great amount of precipitate was formed. The mixture was filtered. The filtrate was extracted with AcOEt (300 mL x 2). The organic phase was dried $\left(\mathrm{Na}_{2} \mathrm{SO}_{4}\right)$, filtered, and concentrated in vacuum to give the crude product. The crude was purified by reverse phase (Column: Welch Ultimate XB_C18 32*210 mm 20/40 $\mu \mathrm{m} ; 120 \AA$ Å. Mobile phase: [water( $\left(0.1 \% \mathrm{NH}_{3} \mathrm{H}_{2} 0\right)$ :acetonitrile]. Gradient B\%: 0\%-50\%, $15 \mathrm{~min} ; 50 \%, 5 \mathrm{~min}$. Instrument: TELEDYNE ISCO CombiFlashRf150) to give the product in 17\% yield as a brown oil. Compound Q5 enantiopurity was confirmed by SFC Method (Column: Chiralcel OD-3 50×4.6 mm. I.D., $3 \mu \mathrm{m}$. Mobile phase: methanol $(0.05 \% \mathrm{DEA})$ in $\mathrm{CO}_{2}$ from $5 \%$ to $40 \%$. Flow rate: $3 \mathrm{~mL} / \mathrm{min}$. Wavelength: $\left.220 \mathrm{~nm}\right)$.

${ }^{1} \mathrm{H}$ NMR $\left(500 \mathrm{MHz}, \mathrm{THF}-d_{8}\right) \delta 8.55(\mathrm{~d}, J=4.4 \mathrm{~Hz}, 1 \mathrm{H}), 7.91(\mathrm{~d}, J=9.2 \mathrm{~Hz}, 1 \mathrm{H}), 7.39(\mathrm{~s}, 1 \mathrm{H}), 7.33-7.24$ (m, 2H), $5.86(\mathrm{ddd}, J=17.4,10.3,7.8 \mathrm{~Hz}, 1 \mathrm{H}), 4.98$ (dt, $J=17.4,1.4 \mathrm{~Hz}, 1 \mathrm{H}), 4.91$ (dt, $J=10.3,1.4 \mathrm{~Hz}$, $1 \mathrm{H}), 3.92(\mathrm{~s}, 3 \mathrm{H}), 3.46-3.17(\mathrm{~m}, 3 \mathrm{H}), 3.14(\mathrm{dd}, J=13.6,10.1 \mathrm{~Hz}, 1 \mathrm{H}), 3.03(\mathrm{dd}, J=14.1,7.6 \mathrm{~Hz}, 1 \mathrm{H})$, $2.76-2.60$ (m, 2H), 2.27 (brs, 1H), 1.89 (ddt, $J=13.1,9.7,3.3 \mathrm{~Hz}, 1 \mathrm{H}), 1.80-1.63$ (m, 2H), $1.63-1.50$ $(\mathrm{m}, 1 \mathrm{H}), 1.23(\mathrm{dd}, \mathrm{J}=12.4,6.4 \mathrm{~Hz}, 1 \mathrm{H}) .{ }^{13} \mathrm{C} \mathrm{NMR}(126 \mathrm{MHz}, \mathrm{THF}) \delta 158.9,148.3,146.0,144.7,143.3$, $132.9,129.8,122.8,121.8,114.4,102.7,57.1,57.0,56.0,41.8,41.1,38.7,30.0,29.6,29.1 . \mathrm{HRMS}(\mathrm{m} / \mathrm{z})$ : $[\mathrm{M}+\mathrm{H}]^{+}$calcd for $\left[\mathrm{C}_{20} \mathrm{H}_{25} \mathrm{~N}_{2} \mathrm{O}\right]$ 309.1961; found 309.1953.

(1R,2S,4S,5R)-2-((R)-hydroxy(6-methoxyquinolin-4-yl)methyl)-1-pentyl-5-vinylquinuclidin-1-ium, Q6
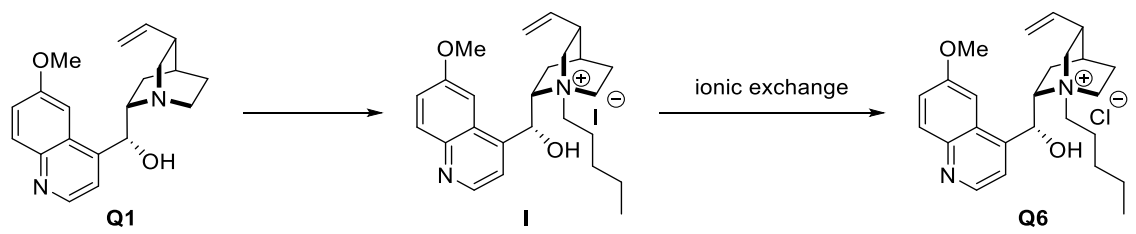

To a solution of quinine Q1 (2.74 g, $8.44 \mathrm{mmol}, 1.1 \mathrm{eq})$ in THF (15.2 mL) at ambient temperature was added 1-iodopentane $(1.00 \mathrm{~mL}, 7.68 \mathrm{mmol}, 1.0 \mathrm{eq})$. The resulting solution was stirred at $50{ }^{\circ} \mathrm{C}$ for $20 \mathrm{~h}$ in a vial capped with a Teflon-lined silicone septum. A nitrogen manifold needle was then connected, and the solution was cooled in an ice bath and seeded with a small amount of crystalline iodide salt $\mathbf{I}$. The resulting thick slurry was filtered, and the cake was washed with THF $(5 \mathrm{~mL})$. The filter cake was dissolved in dichloromethane and purified using a Teledyne ISCO CombiFlash system and an $80 \mathrm{~g}$ silica column, eluting with dichloromethane-methanol 1:0 to 5:1. The unreacted starting material quinine eluted first, followed by the bis-quaternary iodide salt, and then the desired $\mathbf{I}$. The fractions containing mainly the desired product were collected and concentrated. The resulting oil was dissolved in THF ( $5 \mathrm{~mL})$, seeded, then methyl tertbutyl ether $(5 \mathrm{~mL})$ was added to the stirred slurry. The slurry was filtered, and the cake was washed with MTBE and dried in the filter funnel with nitrogen flow-through to provide the $\mathbf{I}$ as a fluffy powder. The 
desired Q6 (chloride salt) was obtained after a subsequent ionic exchange of I based on the following procedure:

\section{Salt IEX Procedure (to Cl)}

For $1 \mathrm{~g}$ of material. Resin: $20 \mathrm{~g}(\sim 30 \mathrm{~mL})$ of macroporous anion exchange resin, chloride form (Bio-Rad AG MP-1M resin, 100-200 mesh, Lot \#64119715). 60 mL funnel.

1. The resin was washed with $5 \times 30 \mathrm{~mL}$ HPLC water and $5 \times 30 \mathrm{~mL}$ of the mixed solvent (MeCN:water).

2. The washed resin was transferred into the $250 \mathrm{~mL}$ round bottle flask with $1 \mathrm{~g}$ of material $\mathbf{I}$ in 80 $\mathrm{mL}$ of the mixed solvent (MeCN:water), and aged for $30 \mathrm{~min}$ at RT.

3. Transferred the slurry resin with material into funnel $(60 \mathrm{~mL})$.

4. Collected the filtrate 1 in $500 \mathrm{~mL}$ round bottle flask.

5. The resin was further washed with $3 \times 30 \mathrm{~mL}$ of the mixed solvent (MeCN:water) and collected the filtrate in $500 \mathrm{~mL}$ round bottle flask with Filtrate 1.

${ }^{1} \mathrm{H}$ NMR (500 MHz, DMSO- $\left.d_{6}\right): \delta(\mathrm{ppm}) 8.78(\mathrm{~d}, J=4.5 \mathrm{~Hz}, 1 \mathrm{H}), 8.00(\mathrm{~d}, J=9.0 \mathrm{~Hz}, 1 \mathrm{H}), 7.69(\mathrm{~d}, J=4.5$ $\mathrm{Hz}, 1 \mathrm{H}), 7.47(\mathrm{dd}, J=9.2,2.5 \mathrm{~Hz}, 1 \mathrm{H}), 7.28(\mathrm{~d}, J=2.8 \mathrm{~Hz}, 1 \mathrm{H}), 6.93(\mathrm{~s}, 1 \mathrm{H}), 6.22(\mathrm{~d}, J=4.8 \mathrm{~Hz}, 1 \mathrm{H}), 5.77$ $(\mathrm{ddd}, J=17.3,10.4,6.9 \mathrm{~Hz}, 1 \mathrm{H}), 5.13(\mathrm{~d}, J=17.1 \mathrm{~Hz}, 1 \mathrm{H}), 5.01(\mathrm{dd}, J=10.5,1.3 \mathrm{~Hz}, 1 \mathrm{H}), 4.16-4.06$ (m, $1 \mathrm{H}), 4.00(\mathrm{~s}, 3 \mathrm{H}), 3.86-3.63(\mathrm{~m}, 4 \mathrm{H}), 3.53-2.41(\mathrm{~m}, 2 \mathrm{H}), 2.83-2.73(\mathrm{~m}, 1 \mathrm{H}), 2.21-2.06(\mathrm{~m}, 2 \mathrm{H}), 2.00$ (br, 1H), $1.96-1.77(\mathrm{~m}, 3 \mathrm{H}), 1.53-1.27(\mathrm{~m}, 5 \mathrm{H}), 0.92(\mathrm{~s}, 3 \mathrm{H}) .{ }^{13} \mathrm{C}$ NMR (126 MHz, DMSO- $\left.d_{6}\right): \delta(\mathrm{ppm})$ 157.3, 147.5, 144.2, 143.7, 138.0, 131.5, 125.4, 121.3, 120.3, 116.5, 102.0, 66.1, 63.5, 59.8, 59.6, 55.5, 52.1, 37.5, 28.3, 25.9, 24.6, 21.7, 21.6, 20.2, 13.8. HRMS(m/z): $[\mathrm{M}+\mathrm{H}]^{+}$calcd for $\left[\mathrm{C}_{25} \mathrm{H}_{35} \mathrm{~N}_{2} \mathrm{O}_{2}\right] 395.2693$; found 395.2683 .

(1R,2S,4S,5R)-2-((R)-hydroxy(6-methoxy-1-pentylquinolin-1-ium-4-yl)methyl)-1-pentyl-5vinylquinuclidin-1-ium chloride, $Q 7$
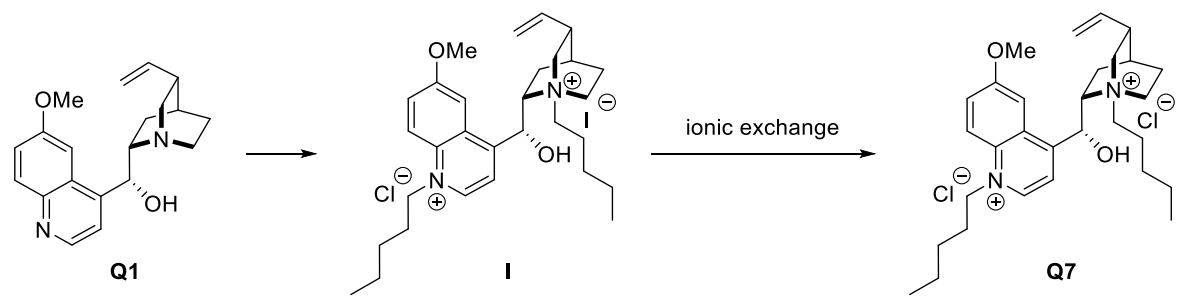

To a solution of quinine Q1 (1.00 g, $3.08 \mathrm{mmol}, 1.0 \mathrm{eq})$ in $N, N$-dimethylformamide (2 mL) and isopropanol $(0.5 \mathrm{~mL})$ at ambient temperature was added 1-iodopentane $(1.61 \mathrm{~mL}, 12.3 \mathrm{mmol}, 4.0 \mathrm{eq})$. The resulting solution was stirred at $90{ }^{\circ} \mathrm{C}$ for $5 \mathrm{~h}$ and then at $70{ }^{\circ} \mathrm{C}$ for 3 days in a vial capped with a Teflon-lined silicone 
septum. The reaction mixture was purified using a Teledyne ISCO CombiFlash system and a $120 \mathrm{~g}$ silica column, eluting with dichloromethane-methanol 1:0 to 4:1. The fractions containing mainly the desired bisiodide salt I were collected and concentrated. The resulting oil was briefly heated with THF (20 mL), then the biphasic system was cooled to room temperature. The solvent was decanted to provide the bis-iodide salt $\mathbf{I}$ as a viscous oil. The desired $\mathbf{Q 7}$ (chloride salt, light brown solid) was obtained after a subsequent ionic exchange of $\mathbf{I}$ based on the procedure described above.

${ }^{1} \mathrm{H}$ NMR (500 MHz, DMSO- $\left.d_{6}\right): \delta(\mathrm{ppm}) 9.47(\mathrm{~d}, J=6.1 \mathrm{~Hz}, 1 \mathrm{H}), 8.62(\mathrm{~d}, J=9.8 \mathrm{~Hz}, 1 \mathrm{H}), 8.30(\mathrm{~d}, J=6.1$ $\mathrm{Hz}, 1 \mathrm{H}), 7.95(\mathrm{dd}, J=9.7,2.6 \mathrm{~Hz}, 1 \mathrm{H}), 7.79-7.75(\mathrm{~m}, 1 \mathrm{H}), 7.66(\mathrm{~d}, J=2.8 \mathrm{~Hz}, 1 \mathrm{H}), 6.53(\mathrm{~d}, J=5.6 \mathrm{~Hz}$, $1 \mathrm{H}), 5.78$ (ddd, $J=17.4,10.4,7.1 \mathrm{~Hz}, 1 \mathrm{H}), 5.16(\mathrm{dt}, J=17.2,1.4 \mathrm{~Hz}, 1 \mathrm{H}), 5.10-4.98(\mathrm{~m}, 3 \mathrm{H}), 4.15$ (s, $3 \mathrm{H}), 4.23-4.12(\mathrm{~m}, 1 \mathrm{H}), 3.98-3.86(\mathrm{~m}, 2 \mathrm{H}), 3.84-3.69(\mathrm{~m}, 2 \mathrm{H}), 3.56-3.46(\mathrm{~m}, 2 \mathrm{H}), 2.83-2.75(\mathrm{~m}, 1 \mathrm{H})$, $2.23-2.03(\mathrm{~m}, 2 \mathrm{H}), 2.03-1.79(\mathrm{~m}, 6 \mathrm{H}), 1.55-1.25(\mathrm{~m}, 8 \mathrm{H}), 0.96-0.90(\mathrm{~m}, 3 \mathrm{H}), 0.86$ (t, $J=7.0 \mathrm{~Hz}$, $3 \mathrm{H}) .{ }^{13} \mathrm{C}$ NMR (126 MHz, DMSO- $\left.d_{6}\right): \delta$ (ppm) 159.1, 155.7, 145.7, 138.1, 132.7, 128.1, 126.8, 121.7, 121.6, 116.6, 104.8, 66.00, 64.0, 59.8, 59.8, 57.5, 56.4, 51.8, 37.5, 29.4, 28.3, 27.8, 25.9, 24.5, 21.7, 21.6, 21.6, 20.4, 13.8, 13.7. $\mathrm{HRMS}(\mathrm{m} / \mathrm{z}):[\mathrm{M}+2 \mathrm{H}]^{+}$calcd for $\left[\mathrm{C}_{30} \mathrm{H}_{46} \mathrm{~N}_{2} \mathrm{O}_{2}\right] 466.3548$; found 466.3542 .

\section{(R)-(6-fluoroquinolin-4-yl)((1S,2S,4S,5R)-5-vinylquinuclidin-2-yl)methanol, Q8}

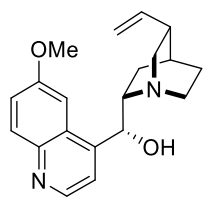

Q1

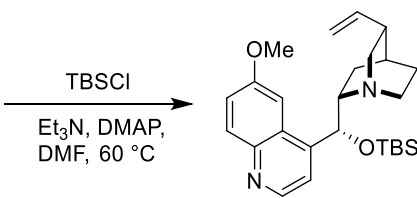

I

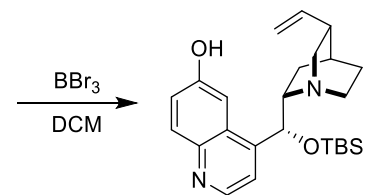

II

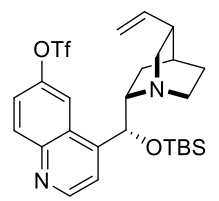

III

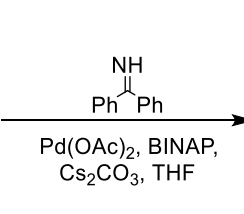

$\mathrm{S}_{2} \mathrm{CO}_{3}, \mathrm{THF}$

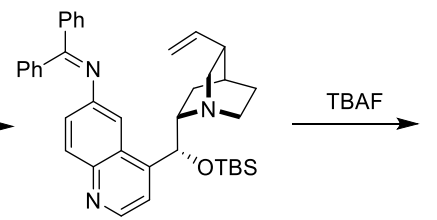

IV

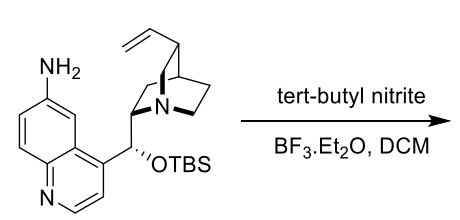

v
$\mathrm{PhN}(\mathrm{Tf})_{2}, 2,6$-Lutidine,

DMAP, DCM

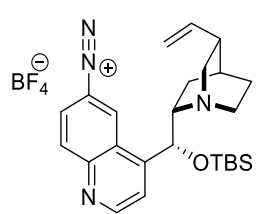

VI
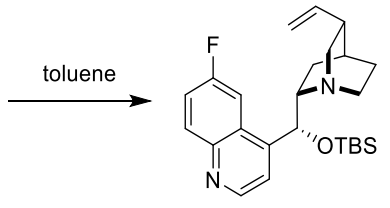

VII

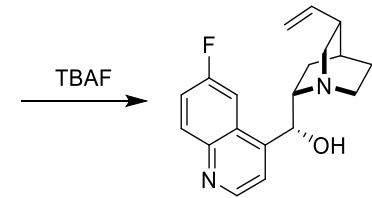

Q8

Quinine (Q1) (200 g, 616.49 mmol, 1 eq) was added to a solution of DMAP (8 g, $65.48 \mathrm{mmol}, 0.106 \mathrm{eq})$ and TEA $(254.45 \mathrm{~g}, 2.51 \mathrm{~mol}, 350 \mathrm{~mL}, 4.08 \mathrm{eq})$ in dry DMF $(1300 \mathrm{~mL})$ at $0{ }^{\circ} \mathrm{C}$. TBSCl $(150 \mathrm{~g}, 995.22$ mmol, $121.95 \mathrm{~mL}, 1.61 \mathrm{eq}$ ) was added next at $0^{\circ} \mathrm{C}$. The mixture was stirred at $50{ }^{\circ} \mathrm{C}$ for $24 \mathrm{~h}$. TLC (DCM:MeOH = 10:1) indicated 50\% of Q1 and one major new spot with larger polarity. The solution was concentrated under reduced pressure. The residue was dissolved with AcOEt (2000 mL), washed with sat. 
$\mathrm{NaHCO}_{3}(1000 \mathrm{~mL})$, brine $(1000 \mathrm{~mL})$, dried with anhydrous $\mathrm{Na}_{2} \mathrm{SO}_{4}$, and filtered. The combined organic layer was concentrated to give the crude product. The desired compound I was purified by silica gel chromatography (Petroleum ether/AcOEt/Et ${ }_{3} \mathrm{~N}=2 / 1 / 0.005$ ). Compound $\mathbf{I}$ was obtained in $55.5 \%$ yield as a yellow solid.

Compound I (210 g, $478.7 \mathrm{mmol}, 1.0 \mathrm{eq})$ was added into the DCM (2 L). The mixture was then cooled to $-40{ }^{\circ} \mathrm{C} . \mathrm{BBr}_{3}(600 \mathrm{~g}, 2390 \mathrm{mmol}, 5.0 \mathrm{eq})$ was added dropwise into the mixture at $-40{ }^{\circ} \mathrm{C}$ for $30 \mathrm{~min}$. Next, the mixture was warmed to $25^{\circ} \mathrm{C}$ and stirred at this temperature for $3 \mathrm{~h}$ until completion as confirmed by LCMS. To the mixture sat. aq. $\mathrm{NaHCO}_{3}(3 \mathrm{~L})$ was added and then was extracted with DCM $(1 \mathrm{~L} x 2)$. Then the combined organic layer was concentrated to give compound II. Compound II was obtained in $93.5 \%$ yield as a yellow solid.

Compound II (190 g, 447.43 mmol, 1.0 eq), 2,6-lutidine (167.83 g, $1570 \mathrm{mmol}, 3.5 \mathrm{eq})$ and DMAP (60.17 $\mathrm{g}, 492.49 \mathrm{mmol}, 1.1 \mathrm{eq})$ were added into the $\mathrm{DCM}(2 \mathrm{~L})$. Then the mixture was cooled to $0{ }^{\circ} \mathrm{C}$. $\mathrm{PhN}(\mathrm{Tf})_{2}$ (191.58 g, $536.27 \mathrm{mmol}, 1.2 \mathrm{eq}$ ) was added dropwise into the mixture at $0{ }^{\circ} \mathrm{C}$ for over $15 \mathrm{~min}$ and then the mixture was stirred at $40{ }^{\circ} \mathrm{C}$ for $12 \mathrm{~h}$ until completion as confirmed by LCMS analysis. The mixture was concentrated to give the crude product. The crude product was purified by silica gel chromatography (Petroleum ether/AcOEt = 1:1, DCM:Methanol = 40:1). Compound III was obtained in $32.1 \%$ yield as a yellow solid.

Compound III, diphenylmethanimine (32 g, 176.57 mmol, $29.63 \mathrm{~mL}, 1.23 \mathrm{eq}), \mathrm{Pd}(\mathrm{OAc})_{2}(4.84 \mathrm{~g}, 21.56$ mmol, $0.15 \mathrm{eq}), \mathrm{Cs}_{2} \mathrm{CO}_{3}(70.23 \mathrm{~g}, 215.55 \mathrm{mmol}, 1.5 \mathrm{eq})$ and BINAP (17.90 g, $\left.28.74 \mathrm{mmol}, 0.2 \mathrm{eq}\right)$ were added into THF (1200 mL) at $25^{\circ} \mathrm{C}$ under $\mathrm{N}_{2}$. The mixture was stirred at $70{ }^{\circ} \mathrm{C}$ for $16 \mathrm{~h}$. Then it was cooled to $25{ }^{\circ} \mathrm{C}$ and filtrated. The solution was poured into $\mathrm{H}_{2} \mathrm{O}(150 \mathrm{~mL})$ and extracted with AcOEt $(300 \mathrm{~mL} \mathrm{x}$ 2), the combined organic phase was washed with brine $(150 \mathrm{~mL})$, dried with anhydrous $\mathrm{Na}_{2} \mathrm{SO}_{4}$, filtered, and concentrated in vacuum. Compound IV (100 g, crude) was obtained as a brown oil and was used directly for the next step without further purification.

Compound IV (100 g, 1 eq) and citric acid (10\% water solution, $1 \mathrm{~L})$ were added into THF (800 mL) at 25 ${ }^{\circ} \mathrm{C}$. The mixture was stirred at $25^{\circ} \mathrm{C}$ for $15 \mathrm{~min}$, as confirmed by LCMS analysis. Next, $\mathrm{HCl}(0.5 \mathrm{M}$ water solution, $300 \mathrm{~mL}$ ) was added and extracted with AcOEt (300 $\mathrm{mL}$ x 2). The $\mathrm{pH}$ of the aqueous phase was adjusted to 8 with aq. $\mathrm{Na}_{2} \mathrm{CO}_{3}$ solution ( $\mathrm{pH} 10$ ) and extracted with AcOEt (300 $\mathrm{mL}$ x 2); the organic phase was washed with brine $(200 \mathrm{~mL})$, dried with anhydrous $\mathrm{Na}_{2} \mathrm{SO}_{4}$, and filtered. Petroleum ether/ AcOEt (10/1, $300 \mathrm{~mL}$ ) was added, and the mixture was stirred for $15 \mathrm{mins}$ at $25^{\circ} \mathrm{C}$, then the suspension was filtered to give compound $\mathbf{V}$ as a yellow solid. The filtrate was concentrated in vacuum, then the residue was purified by silica gel chromatography (Petroleum ether/AcOEt $=1: 1$ ) to give compound $\mathbf{V}$ as a yellow solid $\left[{ }^{1} \mathrm{H}\right.$ NMR (400 MHz, $\mathrm{CDCl}_{3}-d$ ) $\delta$ ppm 0.39 (s, $\left.3 \mathrm{H}\right), 0.15$ (s, $\left.3 \mathrm{H}\right), 0.98(\mathrm{~s}, 9 \mathrm{H}), 1.36$ (br d, J =,2.45 Hz, $1 \mathrm{H}$ ), 
1.52 (br s, 1 H), 1.75 (br s, 1 H), 1.82 (br s, 1 H), 1.90 - 2.00 (m, 3 H) 2.74 (br d, J = 11.49 Hz, 2 H), 2.88 (br s, 1 H), 3.11 (br d, $J=10.76$ Hz, 1 H), 3.47 - 3.62 (m, 1 H), 4.82 - 4.97 (m, 2 H), 5.64 (br s, 2 H), 7.14 (br d, $J=6.60 \mathrm{~Hz}, 2 \mathrm{H}), 7.41(\mathrm{~d}, J=4.40 \mathrm{~Hz}, 1 \mathrm{H}), 7.92$ (br d, $J=9.66 \mathrm{~Hz}, 1 \mathrm{H}), 8.60$ (d, $J=4.52 \mathrm{~Hz}, 1$ $\mathrm{H})]$.

Compound V (35 g, $70.22 \mathrm{mmol}, 1 \mathrm{eq})$ was added into DCM $(400 \mathrm{~mL})$ and then cooled to $0{ }^{\circ} \mathrm{C} . \mathrm{BF}_{3} \cdot \mathrm{Et}_{2} \mathrm{O}$ (25.22 g, $85.30 \mathrm{mmol}, 21.93 \mathrm{~mL}, 1.21 \mathrm{eq})$ and tert-butyl nitrite $(8.00 \mathrm{~g}, 77.55 \mathrm{mmol}, 9.22 \mathrm{~mL}, 1.10 \mathrm{eq})$ in $\operatorname{DCM}(20 \mathrm{~mL})$ was added to the mixture at $0{ }^{\circ} \mathrm{C}$ and stirred for $30 \mathrm{~min}$. LCMS analysis indicated compound $\mathbf{V}$ was consumed, then petroleum ether $(500 \mathrm{~mL})$ was added. The reaction mixture was decanted. Compound VI was obtained at $98.1 \%$ yield as a yellow solid.

Compound VI $\left(60 \mathrm{~g}, 87.28 \mathrm{mmol}, 1 \mathrm{eq}, \mathrm{BF}_{4}\right)$ was added into toluene $(500 \mathrm{~mL})$ at $25^{\circ} \mathrm{C}$, then heated to 100 ${ }^{\circ} \mathrm{C}$, and stirred for $5 \mathrm{~h}$. LCMS analysis indicated the desired MS and reaction completion. Next, the reaction was concentrated and purified by silica gel chromatography (Petroleum ether/AcOEt/Et $3 \mathrm{~N}=2 / 1 / 0.005$ ). Compound VII was obtained in $31.2 \%$ yield as a yellow oil.

The final step was addition of TBAF $(1 \mathrm{M}, 120 \mathrm{~mL}, 4.40 \mathrm{eq})$ in THF into compound VII (15.3 g, 27.25 $\mathrm{mmol}, 1 \mathrm{eq}$ ) at $0{ }^{\circ} \mathrm{C}$. The mixture was stirred at $25^{\circ} \mathrm{C}$ for $2 \mathrm{~h}$. Analysis by LCMS indicated the desired MS and reaction completion. Next, water $(100 \mathrm{~mL})$ was poured into the solution. The solution was extracted with AcOEt (300 mL x 2), the combined organic phase was washed with brine $(100 \mathrm{~mL})$, dried with anhydrous $\mathrm{Na}_{2} \mathrm{SO}_{4}$, filtered, and concentrated in vacuum. Then it was purified by prep HPLC (1/1000 $\mathrm{HCl} / \mathrm{MeCN}$ ) to give the residue, then purified by silica gel chromatography (Petroleum ether/AcOEt= 2/1, 1/1, 5/1000 $\mathrm{Et}_{3} \mathrm{~N}$ ). The desired compound $\mathbf{Q 8}$ was obtained in $95.9 \%$ yield, $98.5 \%$ purity as a white solid. Enantiopurity was confirmed by the SFC method (Column: Cellucoat 50×4.6 mm I.D., $3 \mu \mathrm{m}$; Mobile phase: Phase $\mathrm{A}$ for $\mathrm{CO}_{2}$, and Phase $\mathrm{B}$ for $\mathrm{MeOH}\left(0.05 \%\right.$ DEA). Gradient elution: $\mathrm{MeOH}(0.05 \% \mathrm{DEA})$ in $\mathrm{CO}_{2}$ from 5\% to 40\%. Flow rate: $3 \mathrm{~mL} / \mathrm{min}$. Wavelength: $220 \mathrm{~nm}$. Column Temp: $35{ }^{\circ} \mathrm{C}$. Back Pressure: 100 Bar.

${ }^{1} \mathrm{H}$ NMR (500 MHz, $\left.\mathrm{CDCl}_{3}\right): \delta(\mathrm{ppm}) 8.81(\mathrm{~d}, J=4.4 \mathrm{~Hz}, 1 \mathrm{H}, \mathrm{CH}), 8.10(\mathrm{dd}, J=9.3,5.6 \mathrm{~Hz}, 1 \mathrm{H}, \mathrm{CH})$, $7.73(\mathrm{dd}, J=10.3,2.8 \mathrm{~Hz}, 1 \mathrm{H}), 7.55(\mathrm{~d}, J=4.5 \mathrm{~Hz}, 1 \mathrm{H}), 7.46(\mathrm{td}, J=8.4,2.7 \mathrm{~Hz}, 1 \mathrm{H}), 5.79$ (ddd, $J=17.5$, $10.3,7.5 \mathrm{~Hz}, 1 \mathrm{H}), 5.44$ (d, J=5.3 Hz, 1H), $5.04-4.88$ (m, 2H), $3.36-3.26$ (m, 1H), 3.27 (br, 1H), 3.14 $(\mathrm{td}, J=8.7,5.3 \mathrm{~Hz}, 1 \mathrm{H}), 3.04(\mathrm{dd}, J=13.7,10.0 \mathrm{~Hz}, 1 \mathrm{H}), 2.74-2.52(\mathrm{~m}, 2 \mathrm{H}), 2.32-2.25(\mathrm{~m}, 1 \mathrm{H}), 1.87-$ $1.82(\mathrm{~m}, 1 \mathrm{H}), 1.76-1.67(\mathrm{~m}, 3 \mathrm{H}), 1.57-1.47(\mathrm{~m}, 1 \mathrm{H}) .{ }^{13} \mathrm{C} \mathrm{NMR}\left(126 \mathrm{MHz}, \mathrm{CDCl}_{3}\right): \delta(\mathrm{ppm}) 160.5(\mathrm{~d}, J$ $=248.2 \mathrm{~Hz}), 149.4(\mathrm{~d}, J=2.7 \mathrm{~Hz}), 148.5(\mathrm{~d}, J=5.9 \mathrm{~Hz}), 145.5,141.8,132.8(\mathrm{~d}, J=9.4 \mathrm{~Hz}), 126.6(\mathrm{~d}, J=$ $9.6 \mathrm{~Hz}), 119.3(\mathrm{~d}, J=25.6 \mathrm{~Hz}), 119.0,114.4,107.0$ (d, $J=23.0 \mathrm{~Hz}), 72.4,60.3,56.9,43.0,39.9,27.8,27.7$, 22.7. ${ }^{19} \mathrm{~F}$ NMR $\left(471 \mathrm{MHz}, \mathrm{CDCl}_{3}\right) \delta(\mathrm{ppm})-111.60$. $\mathrm{HRMS}(\mathrm{m} / \mathrm{z}):[\mathrm{M}+\mathrm{H}]^{+}$calcd for $\left[\mathrm{C}_{19} \mathrm{H}_{22} \mathrm{FN}_{2} \mathrm{O}\right]$ 313.1711; found 313.1703. 
(R)-(6-methylquinolin-4-yl)((1S,2S,4S,5R)-5-vinylquinuclidin-2-yl)methanol, Q10

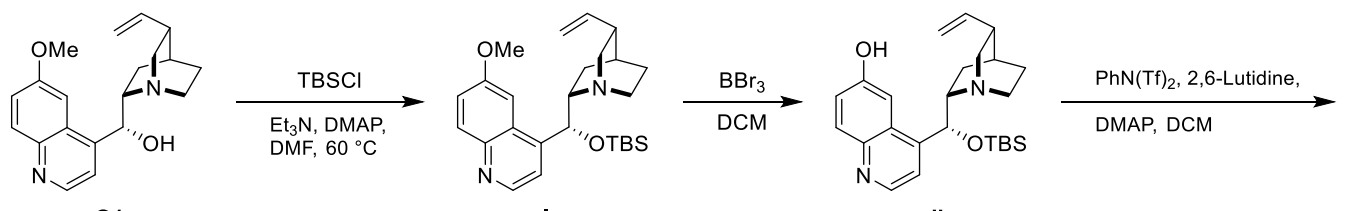

Q1

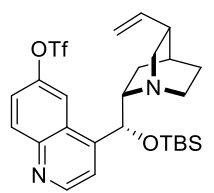

III

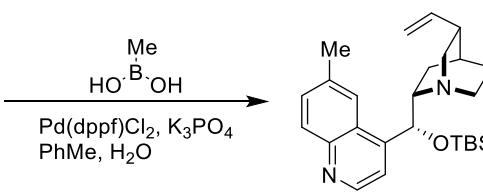

IV

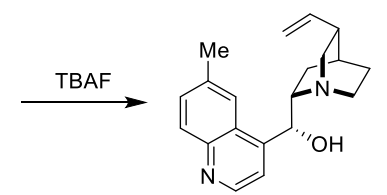

Q10

Quinine (Q1) (200 g, 616.49 mmol, 1 eq) was added to a solution of DMAP (8 g, 65.48 mmol, 0.106 eq) and TEA $(254.45 \mathrm{~g}, 2.51 \mathrm{~mol}, 350 \mathrm{~mL}, 4.08 \mathrm{eq})$ in dry DMF $(1.3 \mathrm{~L})$ at $0{ }^{\circ} \mathrm{C}$. TBSCl $(150 \mathrm{~g}, 995.22 \mathrm{mmol}$, $121.95 \mathrm{~mL}, 1.61 \mathrm{eq}$ ) was added next at $0^{\circ} \mathrm{C}$. The mixture was stirred at $50{ }^{\circ} \mathrm{C}$ for $24 \mathrm{~h}$. TLC (DCM:MeOH $=10: 1$ ) indicated 50\% of $\mathbf{Q 1}$ and one major new spot with larger polarity. The solution was concentrated under reduced pressure. The residue was dissolved with $\operatorname{AcOEt}(2 \mathrm{~L})$, washed with sat $\mathrm{NaHCO}_{3}(1 \mathrm{~L})$, brine $(1 \mathrm{~L})$, dried with anhydrous $\mathrm{Na}_{2} \mathrm{SO}_{4}$, and filtered. The combined organic layer was concentrated to give the crude product. The desired compound I was purified by silica gel chromatography (Petroleum ether/AcOEt/Et $\left.{ }_{3} \mathrm{~N}=2 / 1 / 0.005\right)$. Compound I was obtained in $55.5 \%$ yield as a yellow solid.

Compound I (210 g, 478.7 mmol, $1.0 \mathrm{eq})$ was dissolved in DCM (2 L). The mixture was then cooled to $40{ }^{\circ} \mathrm{C} . \mathrm{BBr}_{3}(600 \mathrm{~g}, 2390 \mathrm{mmol}, 5.0 \mathrm{eq})$ was added drop-wise into the mixture at $-40{ }^{\circ} \mathrm{C}$ for $30 \mathrm{~min}$. Next, the mixture was warmed to $25{ }^{\circ} \mathrm{C}$ and stirred at $25^{\circ} \mathrm{C}$ for $3 \mathrm{~h}$ to completion as confirmed by LCMS. Sat aq $\mathrm{NaHCO}_{3}(3 \mathrm{~L})$ was added to the mixture, extracted with DCM $(1 \mathrm{~L}$ x 2), then the combined organic layer was concentrated to give compound II. Compound II was obtained in $93.5 \%$ yield as a yellow solid.

Compound II (190 g, 447.43 mmol, 1.0 eq), 2,6-lutidine (167.83 g, 1570 mmol, 3.5 eq) and DMAP (60.17 $\mathrm{g}, 492.49 \mathrm{mmol}, 1.1 \mathrm{eq})$ were added into DCM $(2000 \mathrm{~mL})$. Then the mixture was cooled to $0{ }^{\circ} \mathrm{C}$. $\mathrm{PhN}(\mathrm{Tf})_{2}$ (191.58 g, $536.27 \mathrm{mmol}, 1.2 \mathrm{eq}$ ) was added drop-wise into the mixture at $0{ }^{\circ} \mathrm{C}$ over $15 \mathrm{~min}$, and then the mixture was stirred at $40{ }^{\circ} \mathrm{C}$ for $12 \mathrm{~h}$ to completion as confirmed by LCMS analysis. The mixture was concentrated to give the crude product. The crude product was purified by silica gel chromatography (Petroleum ether/AcOEt $=1: 1, \mathrm{DCM} /$ Methanol $=40: 1)$. Compound III was obtained in $32.1 \%$ yield as a yellow solid.

Compound III (20 g, 35.93 mmol, 1 eq), methylboronic acid (5.5 g, $91.88 \mathrm{mmol}, 2.56 \mathrm{eq}), \mathrm{K}_{3} \mathrm{PO}_{4}(19 \mathrm{~g}$, $89.51 \mathrm{mmol}, 2.49 \mathrm{eq})$ and $\mathrm{Pd}(\mathrm{dppf}) \mathrm{Cl}_{2}(2 \mathrm{~g}, 2.73 \mathrm{mmol}, 0.0761 \mathrm{eq})$ were added into the toluene/ $\mathrm{H}_{2} \mathrm{O}(3 / 1$, $400 \mathrm{~mL}$ ). The mixture was purged and degassed with $\mathrm{N}_{2} 3$ times and then heated to $80^{\circ} \mathrm{C}$. The mixture was 
stirred at $80^{\circ} \mathrm{C}$ for $16 \mathrm{~h}$ until completion, as confirmed by LCMS analysis. Next, water $(100 \mathrm{~mL})$ was added and extracted with AcOEt (200 mL x 2). The combined organic phase was washed with brine (100 mL) and dried with anhydrous $\mathrm{Na}_{2} \mathrm{SO}_{4}$. The organic layer was combined to give the crude product. The crude product was purified by silica gel chromatography (Petroleum ether/AcOEt/Et $3 \mathrm{~N}=1: 1: 0.05$ ) to obtain compound IV in $52.7 \%$ yield as a brown oil.

Compound IV (15.1 g, $35.7 \mathrm{mmol}, 1.0 \mathrm{eq})$ was added into TBAF (1 M in THF, $120 \mathrm{~mL}, 120 \mathrm{mmol}, 3.36$ eq) at $25^{\circ} \mathrm{C}$ and the mixture was stirred at $25^{\circ} \mathrm{C}$ for $12 \mathrm{~h}$, as completion of the reaction was confirmed by LCMS analysis. Water $(100 \mathrm{~mL})$ was added and extracted with AcOEt $(300 \mathrm{~mL}$ x 2). The organic layer was combined to give the crude product. Compound Q10 was purified by recrystallization with AcOEt (100 $\mathrm{mL})$. The crude product was added into $\mathrm{AcOEt} / \mathrm{DCM}(10 / 1,25 \mathrm{~mL})$, and the mixture was stirred at $25^{\circ} \mathrm{C}$ for $15 \mathrm{~min}$. Next, it was filtered, concentrated, and purified by prep HPLC (1/1000 $\mathrm{HCl} / \mathrm{MeCN})$ to give Compound Q10 as off-white solid. The solid's enantiopurity was confirmed by the SFC Method (Column: Chiralcel OD-3 50×4.6 mm I.D., $3 \mu \mathrm{m}$. Mobile phase: Phase A for $\mathrm{CO}_{2}$, and Phase B for $\mathrm{MeOH}(0.05 \%$ DEA). Gradient elution: $\mathrm{MeOH}\left(0.05 \%\right.$ DEA) in $\mathrm{CO}_{2}$ from $5 \%$ to $40 \%$. Flow rate: $3 \mathrm{~mL} / \mathrm{min}$. Wavelength: 220 nm; Column Temp: $35^{\circ} \mathrm{C}$. Back Pressure: 100 Bar).

${ }^{1} \mathrm{H}$ NMR (500 MHz, $\left.\mathrm{CDCl}_{3}\right): \delta(\mathrm{ppm}) 8.76(\mathrm{~d}, J=4.5 \mathrm{~Hz}, 1 \mathrm{H}), 7.98(\mathrm{~d}, J=8.6 \mathrm{~Hz}, 1 \mathrm{H}), 7.78(\mathrm{~s}, 1 \mathrm{H}), 7.62$ $-7.45(\mathrm{~m}, 2 \mathrm{H}), 5.76(\mathrm{ddd}, J=17.6,10.3,7.7 \mathrm{~Hz}, 1 \mathrm{H}), 5.60(\mathrm{~d}, J=4.4 \mathrm{~Hz}, 1 \mathrm{H}), 5.07-4.84(\mathrm{~m}, 2 \mathrm{H}), 3.44$ - 3.35 (m, 1H), $3.15-3.05(\mathrm{~m}, 2 \mathrm{H}), 3.00(\mathrm{~s}, 1 \mathrm{H}), 2.72-2.59$ (m, 2H), 2.54 (s, 3H), 2.27 (br, 1H), 1.83 $1.79(\mathrm{~m}, 1 \mathrm{H}), 1.79-1.65(\mathrm{~m}, 2 \mathrm{H}), 1.62-1.54(\mathrm{~m}, 1 \mathrm{H}), 1.53-1.44(\mathrm{~m}, 1 \mathrm{H}) .{ }^{13} \mathrm{C} \mathrm{NMR}\left(126 \mathrm{MHz}, \mathrm{CDCl}_{3}\right)$ : $\delta$ (ppm) 149.3, 148.1, 146.8, 142.0, 131.3, 130.0, 125.7, 121.8, 118.1, 114.3, 72.0, 60.2, 57.2, 43.2, 40.0, 27.9, 27.7, 21.98, 21.96. HRMS(m/z): $[\mathrm{M}+\mathrm{H}]^{+}$calcd for $\left[\mathrm{C}_{20} \mathrm{H}_{25} \mathrm{~N}_{2} \mathrm{O}\right]$ 309.1961; found 309.1952.

\section{N,N-diethyl-2-(6-methoxyquinolin-4-yl)ethan-1-amine, $Q 11$}

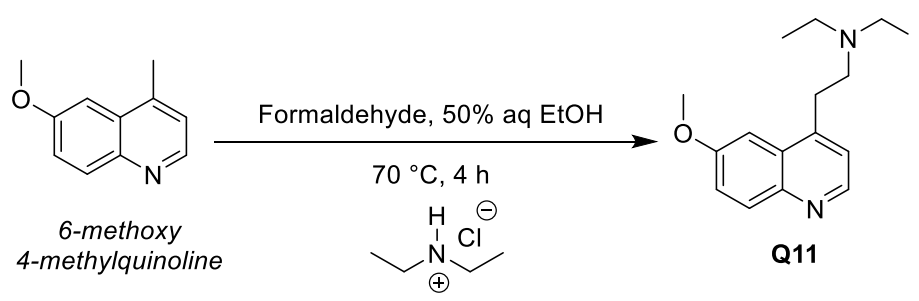

Catalyst (Q11) was synthesized by heating a mixture of 6-methoxy-4-methylquinoline (2 g, $11.55 \mathrm{mmol}, 1$ eq), diethylamine hydrochloride (1.26 g, $11.55 \mathrm{mmol}, 1 \mathrm{eq})$, and formaldehyde (37 wt $\%, 0.95 \mathrm{~mL}, 1.1 \mathrm{eq})$ in $50 \%$ aq $\mathrm{EtOH}(8 \mathrm{~mL})$ at $70{ }^{\circ} \mathrm{C}$ for 4 hours. Next, the reaction was concentrated under pressure to remove the alcohol and then diluted with water. The unreacted starting material was then extracted with tert-butyl methyl ether. The aqueous layer containing the protonated Q11 was treated with $\mathrm{Na}_{2} \mathrm{CO}_{3}(3.2 \mathrm{~g}, 2.6 \mathrm{eq})$ to generate this compound's free base. Then it was extracted with tert-butyl methyl ether, followed by removal 
of this solvent to generate a crude oil. The mixture was purified by normal-phase column chromatography $\left(2 \% \mathrm{Et}_{3} \mathrm{~N}\right.$ in $\left.\mathrm{MeOH} / \mathrm{DCM}\right)$ to generate $\mathbf{Q 1 1}$ in $20 \%$ yield and high purity.

${ }^{1} \mathrm{H}$ NMR (500 MHz, CDCl $)$ ): $\delta(\mathrm{ppm}) 8.57(\mathrm{~d}, J=5.0 \mathrm{~Hz}, 1 \mathrm{H}), 7.91(\mathrm{~d}, J=10 \mathrm{~Hz}, 1 \mathrm{H}), 7.31-7.33(\mathrm{~m}, 2 \mathrm{H})$, $7.23(\mathrm{~d}, J=5.0 \mathrm{~Hz}, 1 \mathrm{H}), 3.91(\mathrm{~s}, 3 \mathrm{H}), 3.11(\mathrm{t}, J=5 \mathrm{~Hz}, 2 \mathrm{H}), 2.76(\mathrm{t}, J=5 \mathrm{~Hz}, 2 \mathrm{H}), 2.57$ (dd, $J=15 \mathrm{~Hz}, J$ $=5 \mathrm{~Hz}, 4 \mathrm{H}), 0.98(\mathrm{t}, J=5 \mathrm{~Hz}, 6 \mathrm{H}) .{ }^{13} \mathrm{C} \mathrm{NMR}\left(126 \mathrm{MHz}, \mathrm{CDCl}_{3}\right): \delta(\mathrm{ppm}) 158.6,148.6,146.6,145.4$, 132.4, 129.5, 122.8, 122.2, 102.8, 56.2, 53.6, 47.7, 30.6, 12.6. HRMS(m/z): $[\mathrm{M}+\mathrm{H}]^{+}$calcd for $\left[\mathrm{C}_{16} \mathrm{H}_{23} \mathrm{~N}_{2} \mathrm{O}\right]$ 259.1805; found 259.1800. 


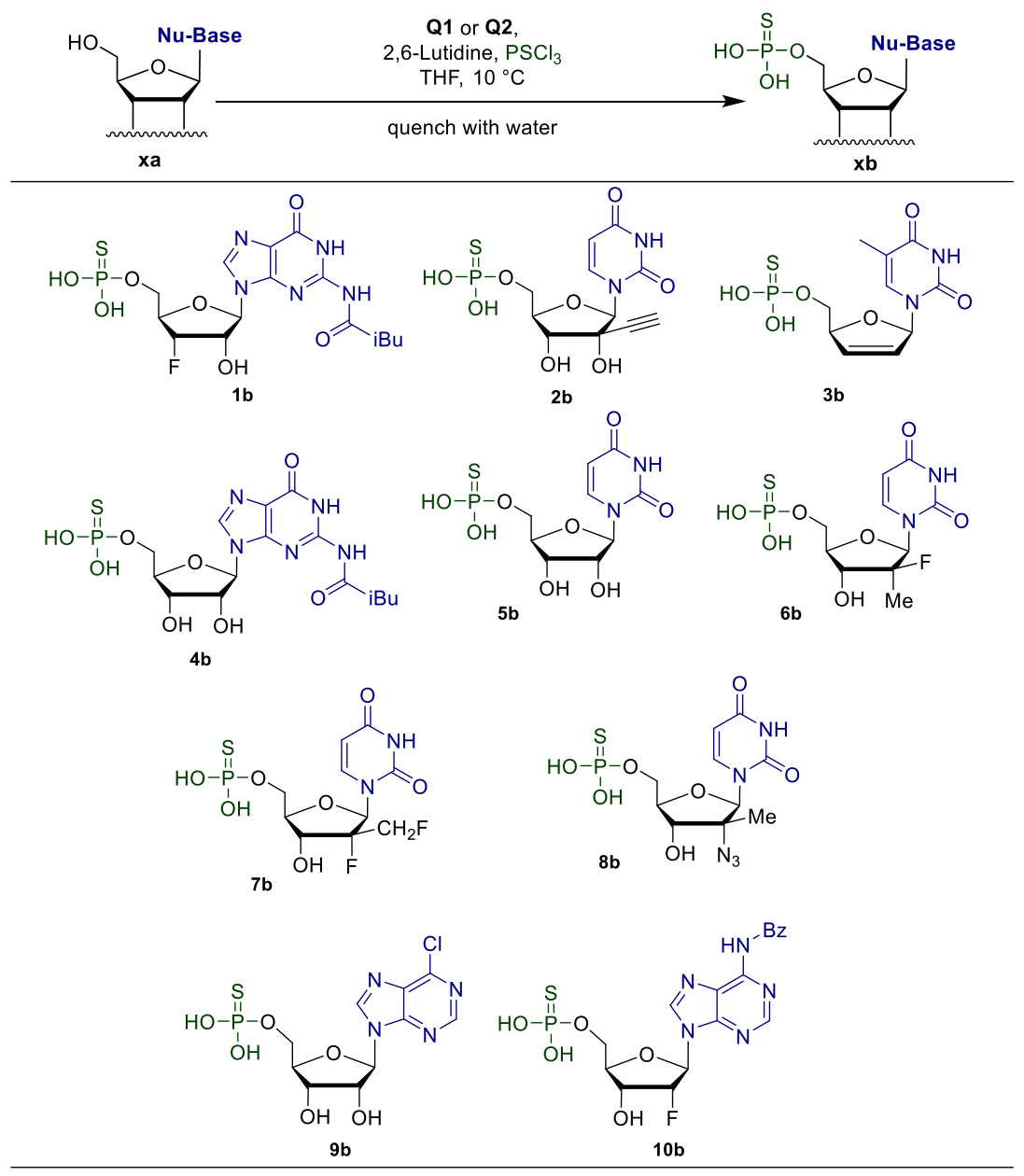

\subsection{General procedure for the synthesis of thiophosphate esters $1 \mathrm{~b}-10 \mathrm{~b}$}

The starting material (1 eq), quinine (Q1, 0.25 eq) or N-benzyl quinine chloride (Q2, 0.25 eq), and 2,6lutidine (3 eq) were dissolved in THF (20 v or $20 \mathrm{~mL} / \mathrm{g}$ ) and stirred at $0{ }^{\circ} \mathrm{C}$. Phosphorothioyl trichloride (2 eq) was dissolved in THF (10 v or $10 \mathrm{~mL} / \mathrm{g})$ and added slowly to the reaction at $0{ }^{\circ} \mathrm{C}$. The reaction mixture was stirred at $0{ }^{\circ} \mathrm{C}-10{ }^{\circ} \mathrm{C}$ until completion. The mixture was cooled to $0{ }^{\circ} \mathrm{C}$, quenched with water or $0.5 \mathrm{M}$ $\mathrm{NH}_{4} \mathrm{HCO}_{3}(30 \mathrm{v}$ or $30 \mathrm{~mL} / \mathrm{g}$ ), then the solvent was evaporated under reduced pressure. The residue was purified by reversed-phased combi-flash chromatography on an AQ - C18 column, Ascentis Express C18 HPLC Column, or Atlantic T3 column, eluting with acetonitrile/water $+0.1 \% \mathrm{NH}_{4} \mathrm{HCO}_{3}$, phase B: 0 0\% $5 \mathrm{~min}$ to $0 \sim 10 \% 10 \mathrm{~min}$ to $70 \sim 70 \% 5 \mathrm{~min}$, followed by lyophilization to yield the product. 


\subsection{Characterization data}

O-(((2R,3S,4S,5R)-3-fluoro-4-hydroxy-5-(2-isobutyramido-6-oxo-1,6-dihydro-9H-purin-9yl)tetrahydrofuran-2-yl)methyl) 0,0 -dihydrogen phosphorothioate, $1 \mathrm{~b}$

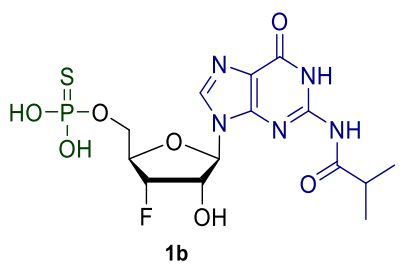

1b was synthesized using the general method with 0.25 eq of quinine. Assay yield was $92 \%$, isolated yield was $89 \%$.

${ }^{1} \mathrm{H}$ NMR (500 MHz, D $\left.2 \mathrm{O}\right): \delta(\mathrm{ppm}) 8.36(\mathrm{~s}, 1 \mathrm{H}), 6.09$ (d, $\left.J=8.1 \mathrm{~Hz}, 1 \mathrm{H}\right), 5.37(\mathrm{dd}, J=53.9,4.3 \mathrm{~Hz}, 1 \mathrm{H})$, 5.12 (ddd, $J=25.4,8.1,4.3 \mathrm{~Hz}, 1 \mathrm{H}), 4.72$ (d, $J=25 \mathrm{~Hz}, 1 \mathrm{H}), 4.33-4.09$ (m, 2H), $2.91-2.64$ (m, 1H), $1.25(\mathrm{~d}, J=7.5 \mathrm{~Hz}, 6 \mathrm{H}) .{ }^{13} \mathrm{C} \mathrm{NMR}\left(126 \mathrm{MHz}, \mathrm{D}_{2} \mathrm{O}\right): \delta(\mathrm{ppm}) 182.2,157.2,149.8,147.9,140.2,120.0,92.8$ $(\mathrm{d}, J=181.3 \mathrm{~Hz}), 86.6,82.7(\mathrm{dd}, J=23.7,9.8 \mathrm{~Hz}), 72.9(\mathrm{~d}, J=16.2 \mathrm{~Hz}), 64.4(\mathrm{dd}, J=12.0,5.2 \mathrm{~Hz}), 35.8$, 18.2. ${ }^{19} \mathrm{~F}$ NMR (471 MHz, $\left.\mathrm{D}_{2} \mathrm{O}\right): \delta(\mathrm{ppm})-198.3 .{ }^{31} \mathrm{P}$ NMR $\left(203 \mathrm{MHz}, \mathrm{D}_{2} \mathrm{O}\right): \delta(\mathrm{ppm}) 50.63 . \mathrm{HRMS}(\mathrm{m} / \mathrm{z})$ : $[\mathrm{M}+\mathrm{H}]^{+}$calcd for $\left[\mathrm{C}_{14} \mathrm{H}_{20} \mathrm{FN}_{5} \mathrm{O}_{7} \mathrm{PS}\right]$ 452.0800; found 452.0791 .

$O-((2 R, 3 R, 4 R, 5 R)-5-(2,4-d i o x o-3,4-d i h y d r o p y r i m i d i n-1(2 H)-y l)-4-e t h y n y l-3,4-d i h y d r o x y-$ tetrahydrofuran-2-yl)methyl 0,0 -dihydrogen phosphorothioate, $2 b$

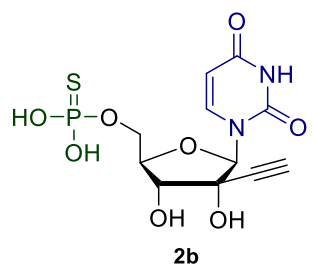

2b was synthesized using the general method with 0.25 eq of N-benzyl quinine chloride. Assay yield was $49 \%$, isolated yield was $41 \%$ using commercially available starting material.

${ }^{1} \mathrm{H}$ NMR (400 MHz, DMSO): $\delta$ (ppm) 11.33 (s, 1H), 7.96 (d, J=8.1 Hz, 1H), 6.20 (s, 1H), 5.88 (s, 1H), $5.75(\mathrm{~s}, 1 \mathrm{H}), 5.63(\mathrm{~d}, J=8.1 \mathrm{~Hz}, 1 \mathrm{H}), 5.25(\mathrm{~s}, 1 \mathrm{H}), 4.02(\mathrm{~d}, J=9.2 \mathrm{~Hz}, 1 \mathrm{H}), 3.85-3.70(\mathrm{~m}, 2 \mathrm{H}), 3.66-$ $3.54(\mathrm{~m}, 1 \mathrm{H}), 3.47$ (s, 1H). ${ }^{13} \mathrm{C}$ NMR (101 MHz , DMSO): $\delta$ (ppm) 163.1, 150.4, 140.3, 101.4, 90.4, 82.1, 77.2, 75.6, 73.6, 58.6, 48.7. ${ }^{31} \mathrm{P}$ NMR (203 MHz, DMSO): $\delta(\mathrm{ppm}) 49.70 . \mathrm{HRMS}(\mathrm{m} / \mathrm{z}):[\mathrm{M}+\mathrm{H}]^{+}$calcd for $\left[\mathrm{C}_{11} \mathrm{H}_{14} \mathrm{~N}_{2} \mathrm{O}_{8} \mathrm{PS} \mathrm{H}\right]$ 365.0208; found 365.0213.

$O-((2 S, 5 R)-5-(5-m e t h y l-2,4-d i o x o-3,4-d i h y d r o p y r i m i d i n-1(2 H)-y l)-2,5-d i h y d r o f u r a n-2-y l) m e t h y l ~ O, O-$ dihydrogen phosphorothioate, $3 b$ 


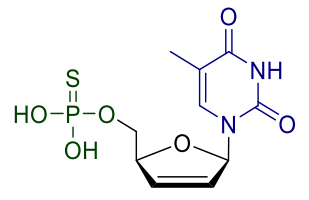

$3 \mathbf{b}$

3b was synthesized using the general method with 0.25 eq of quinine using commercially available starting material. Assay yield was $85 \%$, isolated yield was $57 \%$.

${ }^{1} \mathrm{H}$ NMR (400 MHz, DMSO): $\delta$ (ppm) 7.65 (s, 1H), 6.80 (s, 1H), 6.47 (s, 1H), $5.82(\mathrm{~s}, 1 \mathrm{H}), 4.90$ (s, 1H), 4.04 (s, 1H), 3.85 (s, 1H), 1.83 (s, 3H). ${ }^{13} \mathrm{C}$ NMR (101 MHz, DMSO): $\delta$ (ppm) 164.1, 150.8, 136.8, 135.2, 125.5, 109.9, 88.7, 86.0, 85.9, 64.7, 12.2. ${ }^{31} \mathrm{P}$ NMR (203 MHz, DMSO): $\delta$ (ppm) 47.50. HRMS(m/z): [M $+\mathrm{H}]^{+}$calcd for $\left[\mathrm{C}_{10} \mathrm{H}_{14} \mathrm{~N}_{2} \mathrm{O}_{6} \mathrm{PS} \mathrm{H}\right] 321.0310$; found 321.0325 .

O-((2R,3S,4R,5R)-3,4-dihydroxy-5-(2-isobutyramido-6-oxo-1,6-dihydropurin-9-yl)-tetrahydrofuran-2yl)methyl O,O-dihydrogen phosphorothioate, $4 b$

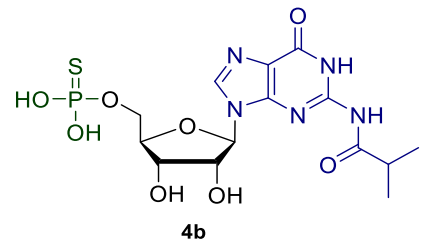

4b was synthesized using the general method with 0.5 eq of $\mathrm{N}$-benzyl quinine chloride using commercially available starting material. Assay yield was $46 \%$, isolated yield was $30 \%$.

${ }^{1} \mathrm{H}$ NMR (300 MHz, DMSO): $\delta(\mathrm{ppm}) 8.18(\mathrm{~s}, 1 \mathrm{H}), 5.72(\mathrm{~d}, J=7.4 \mathrm{~Hz}, 1 \mathrm{H}), 5.36-5.20(\mathrm{~m}, 1 \mathrm{H}), 5.06-$ 4.92 (brs, 1H), 4.17 (brd, $J=4.7 \mathrm{~Hz}, 1 \mathrm{H}), 4.04$ (s, 1H), 3.90 (dd, $J=6.2,2.9 \mathrm{~Hz}, 1 \mathrm{H}$ ), 2.95 (p, J= 7.2 Hz, $1 \mathrm{H}), 1.12(\mathrm{dd}, J=6.8,3.1 \mathrm{~Hz}, 6 \mathrm{H}) .{ }^{13} \mathrm{C}$ NMR (75 MHz, DMSO) $\delta(\mathrm{ppm}) 180.2,155.1,149.0,148.4,137.6$, 120.1, 86.6, 85.4, 74.1, 70.3, 61.2, 34.8, 18.92, 18.90. ${ }^{31} \mathrm{P}$ NMR (162 MHz, DMSO): $\delta$ (ppm) 50.3. $\operatorname{HRMS}(\mathrm{m} / \mathrm{z}):[\mathrm{M}+\mathrm{H}]^{+}$calcd for $\left[\mathrm{C}_{14} \mathrm{H}_{21} \mathrm{~N}_{5} \mathrm{O}_{8} \mathrm{PS} \mathrm{H}\right] 450.0843$; found 450.0833 .

$O-((2 R, 3 S, 4 R, 5 R)-5-(2,4-d i o x o-3,4-d i h y d r o p y r i m i d i n-1(2 H)-y l)-3,4-d i h y d r o x y-t e t r a h y d r o f u r a n-2-$ yl)methyl O,O-dihydrogen phosphorothioate, $5 b$

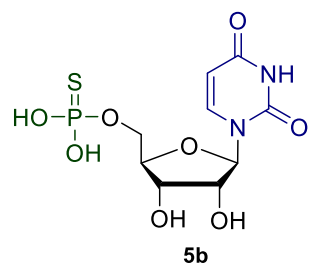


5b was synthesized using the general method with 0.25 eq of quinine using commercially available starting material. Assay yield was $87 \%$, isolated yield was $45 \%$.

${ }^{1} \mathrm{H}$ NMR (400 MHz, DMSO): $\delta(\mathrm{ppm}) 8.07(\mathrm{~m}, 1 \mathrm{H}), 5.80(\mathrm{~d}, J=5.2 \mathrm{~Hz}, 1 \mathrm{H}), 5.62(\mathrm{~d}, J=8.0 \mathrm{~Hz}, 1 \mathrm{H})$, 4.10 (brs, 2H), 3.96 (s, 1H), 3.82 (brs, 2H). ${ }^{13} \mathrm{C}$ NMR (101 MHz , DMSO): $\delta$ (ppm) 163.4, 156.8, 151.1, 141.6, 102.1, 87.3, 73.5, 70.8, 63.9. ${ }^{31} \mathrm{P}$ NMR (203 MHz, DMSO): $\delta$ (ppm) 47.97. HRMS(m/z): [M + H] calcd for $\left[\mathrm{C}_{9} \mathrm{H}_{14} \mathrm{~N}_{2} \mathrm{O}_{8} \mathrm{PS} \mathrm{H}\right] 341.0208$; found 341.0215 .

$O-(((2 R, 3 R, 4 S, 5 R)-5-(2,4-d i o x o-3,4-d i h y d r o p y r i m i d i n-1(2 H)-y l)-4-f l u o r o-3-h y d r o x y-4-$ methyltetrahydrofuran-2-yl)methyl) 0,0 -dihydrogen phosphorothioate, $6 \mathrm{~b}$

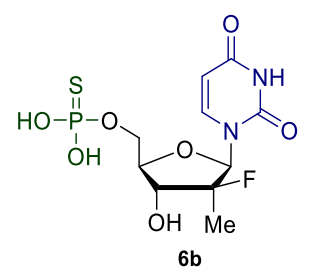

6b was synthesized using the general method with 0.25 eq of quinine using commercially available starting material. Assay yield was $68 \%$, isolated yield was $56 \%$.

${ }^{1} \mathrm{H}$ NMR (400 MHz, DMSO): $\delta$ (ppm) 8.17 (s, 1H), 5.98 (d, $\left.J=18.4 \mathrm{~Hz}, 1 \mathrm{H}\right), 5.63$ (d, $\left.J=7.9 \mathrm{~Hz}, 1 \mathrm{H}\right)$, $4.25-3.82(\mathrm{~m}, 4 \mathrm{H}), 1.24$ (d, $J=22.8 \mathrm{~Hz}, 3 \mathrm{H}) .{ }^{13} \mathrm{C} \mathrm{NMR}$ (101 MHz , DMSO): $\delta$ (ppm) 163.0, 150.7, 135.9, 102.4, 101.1 (d, $J=181.8 \mathrm{~Hz}), 80.7,70.6,60.9,16.6,16.2 .{ }^{31} \mathrm{P}$ NMR (203 MHz, DMSO): $\delta$ (ppm) 50.52. $\operatorname{HRMS}(\mathrm{m} / \mathrm{z}):[\mathrm{M}+\mathrm{H}]^{+}$calcd for $\left[\mathrm{C}_{10} \mathrm{H}_{15} \mathrm{FN}_{2} \mathrm{O}_{7} \mathrm{PS} \quad \mathrm{H}\right] 357.0316$; found 357.0331 .

$O-(((2 R, 3 R, 4 R, 5 R)-5-(2,4-d i o x o-3,4-d i h y d r o p y r i m i d i n-1(2 H)-y l)-4-f l u o r o-4-(f l u o r o m e t h y l)-3-$ hydroxytetrahydrofuran-2-yl)methyl) 0,0 -dihydrogen phosphorothioate, $7 b$

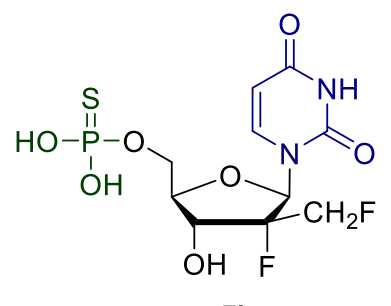

$7 \mathbf{b}$

7b was synthesized using the general method with 0.25 eq of quinine and 0.5 eq of N-benzyl quinine chloride using commercially available starting material. Assay yield was $68 \%$, and isolated yield was $49 \%$ using N-benzyl quinine chloride. Assay yield was 42\%, and isolated yield was $36 \%$ using quinine. 
${ }^{1} \mathrm{H}$ NMR (400 MHz, DMSO): $\delta$ (ppm) 8.00 (d, $\left.J=8.2 \mathrm{~Hz}, 1 \mathrm{H}\right), 6.14(\mathrm{~d}, J=18.7 \mathrm{~Hz}, 1 \mathrm{H}), 5.58(\mathrm{~d}, J=8.1$ $\mathrm{Hz}, 1 \mathrm{H}), 4.82-4.33(\mathrm{~m}, 2 \mathrm{H}), 4.29-3.88(\mathrm{~m}, 4 \mathrm{H}) .{ }^{13} \mathrm{C}$ NMR (101 MHz, DMSO) $\delta$ (ppm) 162.9, 150.3, 140.3, 102.1, 99.6 (dd, J = 185.9, 17.6 Hz), 87.1 (m), 81.6, 80.2 (dd, J = 172.5, 30.4 Hz), 66.9 (d, $J=15.7$ $\mathrm{Hz})$, 58.5. ${ }^{31} \mathrm{P}$ NMR (203 MHz, DMSO): $\delta(\mathrm{ppm})$ 50.16. $\left.\mathrm{HRMS}(\mathrm{m} / \mathrm{z}):[\mathrm{M}+\mathrm{H}]\right]^{+}$calcd for $\left[\mathrm{C}_{10} \mathrm{H}_{14} \mathrm{~F}_{2} \mathrm{~N}_{2} \mathrm{O}_{7} \mathrm{PS}\right.$ H] 375.0222; found 375.0217.

$O-((2 R, 3 S, 4 R, 5 R)-4-a z i d o-5-(2,4-d i o x o-3,4-d i h y d r o p y r i m i d i n-1(2 H)-y l)-3-h y d r o x y-4-m e t h y l-$ tetrahydrofuran-2-yl)methyl 0,0 -dihydrogen phosphorothioate, $8 b$

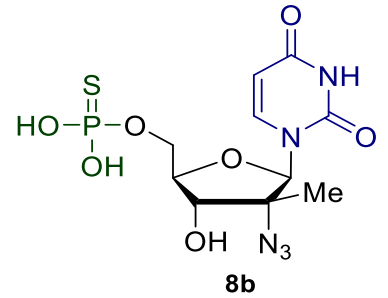

8b was synthesized using the general method with 0.25 eq of quinine and 0.5 eq of N-benzyl quinine chloride using commercially available starting material. Assay yield was $71 \%$, isolated yield was $50 \%$ using N-benzyl quinine chloride. Assay yield was $57 \%$, isolated yield was $45 \%$ using quinine as a catalyst.

${ }^{1} \mathrm{H}$ NMR (400 MHz, DMSO): $\delta$ (ppm) 8.16 (d, $\left.J=8.1 \mathrm{~Hz}, 1 \mathrm{H}\right), 5.66(\mathrm{~s}, 1 \mathrm{H}), 5.58(\mathrm{~d}, J=8.0 \mathrm{~Hz}, 1 \mathrm{H}), 4.19$ - $3.86(\mathrm{~m}, 4 \mathrm{H}), 1.25$ (s, 3H). ${ }^{13} \mathrm{C}$ NMR (101 MHz, DMSO) $\delta(\mathrm{ppm}) 162.9,150.6,139.8,101.8,88.5,82.2$, 73.0, 70.6, 58.2, 15.7. ${ }^{31} \mathrm{P}$ NMR (203 MHz, DMSO): $\delta(\mathrm{ppm})$ 50.27. HRMS(m/z): $[\mathrm{M}+\mathrm{H}]^{+}$calcd for $\left[\mathrm{C}_{10} \mathrm{H}_{15} \mathrm{~N}_{5} \mathrm{O}_{7} \mathrm{PS} \mathrm{H}\right]$ 380.0424; found 380.0430 .

$O-((2 R, 3 S, 4 R, 5 R)-5-(6-c h l o r o-9 H-p u r i n-9-y l)-3,4-d i h y d r o x y-t e t r a h y d r o f u r a n-2-y l) m e t h y l ~ O, O-$ dihydrogen phosphorothioate, $9 b$

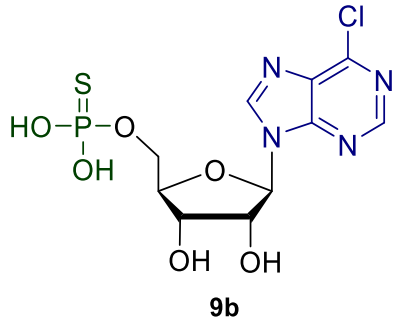

9b was synthesized using the general method with 0.25 eq of quinine using commercially available starting material. Assay yield was $85 \%$, isolated yield was $74 \%$.

${ }^{1} \mathrm{H}$ NMR (300 MHz , DMSO): $\delta$ (ppm) 8.94 (s, 1H), 8.76 (s, 1H), 6.05 (d, $\left.J=4.9 \mathrm{~Hz}, 1 \mathrm{H}\right), 4.59$ (t, $J=4.1$ $\mathrm{Hz}, 1 \mathrm{H}), 4.21(\mathrm{t}, J=4.3 \mathrm{~Hz}, 1 \mathrm{H}), 4.21(\mathrm{q}, J=4.1 \mathrm{~Hz}, 1 \mathrm{H}), 3.71(\mathrm{dd}, J=12.0,3.7 \mathrm{~Hz}, 1 \mathrm{H}), 3.60(\mathrm{dd}, J=$ 
12.0, 3.8 Hz, 1H). ${ }^{13} \mathrm{C}$ NMR (75 MHz, DMSO): $\delta$ (ppm) 151.9, 151.7, 149.5, 145.9, 131.5, 88.4, 85.9, 74.2, 70.2, 61.1. ${ }^{31} \mathrm{P}$ NMR (203 MHz, DMSO): $\delta(\mathrm{ppm})$ 48.52. $\mathrm{HRMS}(\mathrm{m} / \mathrm{z}):[\mathrm{M}+\mathrm{H}]^{+}$calcd for $\left[\mathrm{C}_{10} \mathrm{H}_{13} \mathrm{ClN}_{4} \mathrm{O}_{6} \mathrm{PS}\right.$ H] 382.9976; found 382.9543.

O-((2R,3R,4R,5R)-5-(6-benzamido-9H-purin-9-yl)-4-fluoro-3-hydroxy-tetrahydrofuran-2-yl)methyl O,O-dihydrogen phosphorothioate, $10 b$

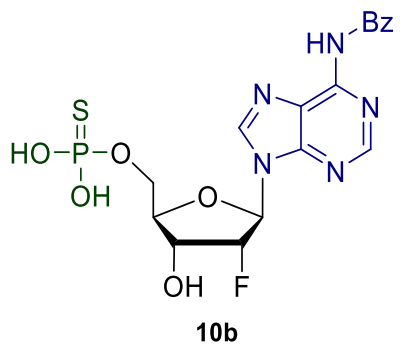

10b was synthesized using the general method with 0.25 eq of quinine using commercially available starting material. Assay yield is $50 \%$, isolated yield is $32 \%$.

${ }^{1} \mathrm{H}$ NMR (300 MHz, DMSO): $\delta$ (ppm) 9.09 - 8.61 (m, 2H), 8.06 (d, J= 7.2 Hz, 2H), $7.72-7.41$ (m, 3H), $6.40(\mathrm{dd}, J=15.5,2.5 \mathrm{~Hz}, 1 \mathrm{H}), 5.77-5.35(\mathrm{~m}, 1 \mathrm{H}), 4.82-4.46(\mathrm{~m}, 1 \mathrm{H}), 4.40-3.55(\mathrm{~m}, 3 \mathrm{H}), 1.541(\mathrm{br}, 1 \mathrm{H})$. ${ }^{13} \mathrm{C}$ NMR (75 MHz , DMSO): $\delta$ (ppm) 166.0, 152.0, 151.9, 150.3, 143.1, 133.5, 132.5, 128.6, 128.5, 125.1, $93.8(\mathrm{~d}, J=188.3 \mathrm{~Hz}), 85.5$ (d, $J=33.0 \mathrm{~Hz}), 83.9,69.1$ (d, $J=14.3 \mathrm{~Hz}), 63.3 .{ }^{31} \mathrm{P}$ NMR (203 MHz, DMSO): $\delta(\mathrm{ppm})$ 50.02. $\mathrm{HRMS}(\mathrm{m} / \mathrm{z}):[\mathrm{M}+\mathrm{H}]^{+}$calcd for $\left[\mathrm{C}_{17} \mathrm{H}_{18} \mathrm{FN}_{5} \mathrm{O}_{6} \mathrm{PS} \mathrm{H}\right]$ 470.0694; found 470.0712.

$N-(9-((2 R, 3 S, 4 S, 5 R)-4-f l u o r o-3-h y d r o x y-5-(h y d r o x y m e t h y l) t e t r a h y d r o f u r a n-2-y l)-6-o x o-6,9-d i h y d r o-$ 1H-purin-2-yl)octanamide, $1 a^{\text {, }}$

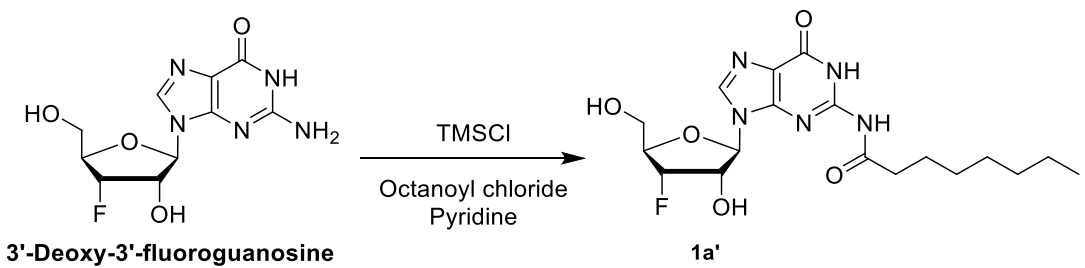

The starting material $(5.0 \mathrm{~g}, 17.53 \mathrm{mmol}, 1.0 \mathrm{eq})$ was added into pyridine (110 mL, $22 \mathrm{~mL} / \mathrm{g})$. Next, TMSCl (7.05 g, $8.29 \mathrm{~mL}, 64.9 \mathrm{mmol}, 3.7 \mathrm{eq}$ ) was added to the mixture at $25^{\circ} \mathrm{C}$. The reaction was aged at $25^{\circ} \mathrm{C}$ for $1 \mathrm{~h}$ then cooled down to $0{ }^{\circ} \mathrm{C}$, followed by the addition of octanoyl chloride $(3.71 \mathrm{~g}, 3.89 \mathrm{~mL}, 22.79$ $\mathrm{mmol}, 1.3 \mathrm{eq})$ at $0{ }^{\circ} \mathrm{C}$. The reaction was then aged at $25{ }^{\circ} \mathrm{C}$ for $5-6 \mathrm{~h}$ to complete. After confirming the reaction completion by UPLC analysis, the mixture was quenched with water $(4.5 \mathrm{~mL} / \mathrm{g}, 22.50 \mathrm{~mL})$, followed by the addition of ammonia in $\mathrm{EtOH}(5 \mathrm{~mL} / \mathrm{g}, 25.0 \mathrm{~mL})$. The solvent was then removed under 
reduced pressure to give the crude product. Compound 1a' was purified by normal phase column chromatography (ISCO) to obtain the desired product in high purity (>99\%) for mechanistic studies.

${ }^{1} \mathrm{H}$ NMR (500 MHz, THF- $\left.d 8\right): \delta(\mathrm{ppm}) 11.96$ (s, 1H), 10.83 (s, 1H), 8.05 (s, 1H), 5.88 (d, J= $\left.7.4 \mathrm{~Hz}, 1 \mathrm{H}\right)$, $5.48(\mathrm{~d}, J=5.9 \mathrm{~Hz}, 1 \mathrm{H}), 5.09(\mathrm{dd}, J=54.6,4.2 \mathrm{~Hz}, 1 \mathrm{H}), 4.85(\mathrm{dddd}, J=24.1,7.3,5.8,4.2 \mathrm{~Hz}, 1 \mathrm{H}), 4.75$ $(\mathrm{t}, J=5.1 \mathrm{~Hz}, 1 \mathrm{H}), 4.33-4.19(\mathrm{~m}, 1 \mathrm{H}), 3.83-3.67(\mathrm{~m}, 2 \mathrm{H}), 2.50(\mathrm{t}, J=7.5 \mathrm{~Hz}, 2 \mathrm{H}), 1.73-1.67(\mathrm{~m}, 2 \mathrm{H})$, $1.47-1.23(\mathrm{~m}, 8 \mathrm{H}), 0.89$ (t, $J=7.0 \mathrm{~Hz}, 3 \mathrm{H}) .{ }^{13} \mathrm{C}$ NMR (125 MHz, THF- $\left.d 8\right): \delta$ (ppm) 176.8, 155.7, 150.0, 149.4, 138.0, 121.4, 94.5 (d, $J=183.6 \mathrm{~Hz}), 88.3,85.4$ (d, $J=21.8 \mathrm{~Hz}), 75.9$ (d, $J=15.9 \mathrm{~Hz}), 62.6,62.5$, 37.5, 32.8, 30.2, 30.2, 25.8, 23.7, 14.6. ${ }^{19} \mathrm{~F}$ NMR (471 MHz, THF- $\left.d_{8}\right) \delta-200.99$. HRMS(m/z): $[\mathrm{M}+\mathrm{H}]^{+}$ calcd for $\left[\mathrm{C}_{18} \mathrm{H}_{27} \mathrm{FN}_{5} \mathrm{O}_{5}\right]$ 412.1991; found 412.1980.

O-(((2R,3S,4S,5R)-3-fluoro-4-hydroxy-5-(2-octanamido-6-oxo-1,6-dihydro-9H-purin-9-

yl)tetrahydrofuran-2-yl)methyl) 0,0 -dihydrogen phosphorothioate, $1 b^{\prime}$

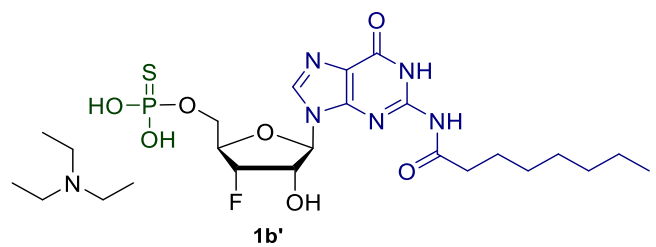

1b' was synthesized using the general method with 0.20 eq of quinine using commercially available starting material. Assay yield was 97\%, isolated yield for the triethylamine salt of 1b' compound was $83 \%$.

${ }^{1} \mathrm{H}$ NMR (600 MHz, D $\left.2 \mathrm{O}\right): \delta(\mathrm{ppm}) 8.37$ (s, 1H), $5.94(\mathrm{~d}, \mathrm{~J}=7.7 \mathrm{~Hz}, 1 \mathrm{H}), 5.28(\mathrm{~d}, J=56.5 \mathrm{~Hz}, 1 \mathrm{H}), 4.94$ (brd, $J=26.6 \mathrm{~Hz}, 1 \mathrm{H}), 4.48$ (d, $J=27.4 \mathrm{~Hz}, 1 \mathrm{H}), 4.05$ (brs, 1H), 3.97 (brs, 1H), 3.16 (q, $J=7.3 \mathrm{~Hz}, 12 \mathrm{H})$, 2.52 (brs, 2H), 1.59 (brs, 2H), $1.36-1.09$ (m, 26H), 0.80 (t, J = 6.3 Hz, 3H). ${ }^{13} \mathrm{C}$ NMR $\left(151 \mathrm{MHz}, \mathrm{D}_{2} \mathrm{O}\right) \delta$ (ppm) 177.2, 156.3, 149.7, 147.9, 139.6, 119.3, 93.3 (d, $J=181.3 \mathrm{~Hz}), 86.1,83.2(\mathrm{dd}, J=22.9,9.6 \mathrm{~Hz})$, $73.8(\mathrm{~d}, J=15.9 \mathrm{~Hz}), 63.8(\mathrm{~d}, J=8.7 \mathrm{~Hz}), 46.6,36.5,31.5,29.0,28.8,24.5,22.5,13.8,8.3 .{ }^{31} \mathrm{P}$ NMR $(243$ $\left.\mathrm{MHz}, \mathrm{D}_{2} \mathrm{O}\right): \delta(\mathrm{ppm})$ 45.8. HRMS(m/z): $[\mathrm{M}+\mathrm{H}]^{+}$calcd for $\left[\mathrm{C}_{18} \mathrm{H}_{28} \mathrm{FN}_{5} \mathrm{O}_{7} \mathrm{PS}\right]$ 508.1426; found 508.1416. 


\section{NMR spectra}

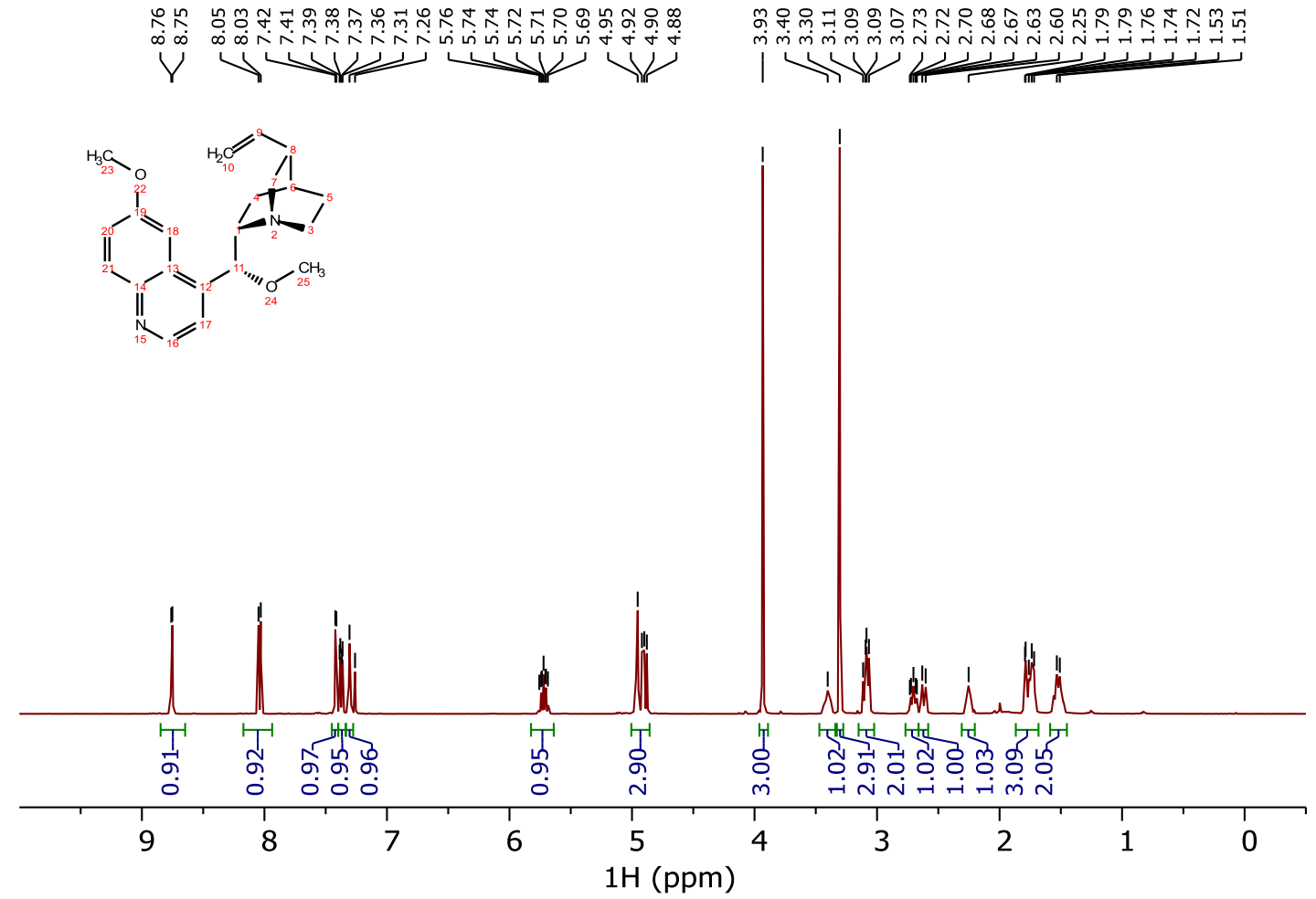

Figure S14. ${ }^{1} \mathrm{H}$ NMR (500 MHz) spectrum of $\mathbf{Q 3}$ in $\mathrm{CDCl}_{3}$.

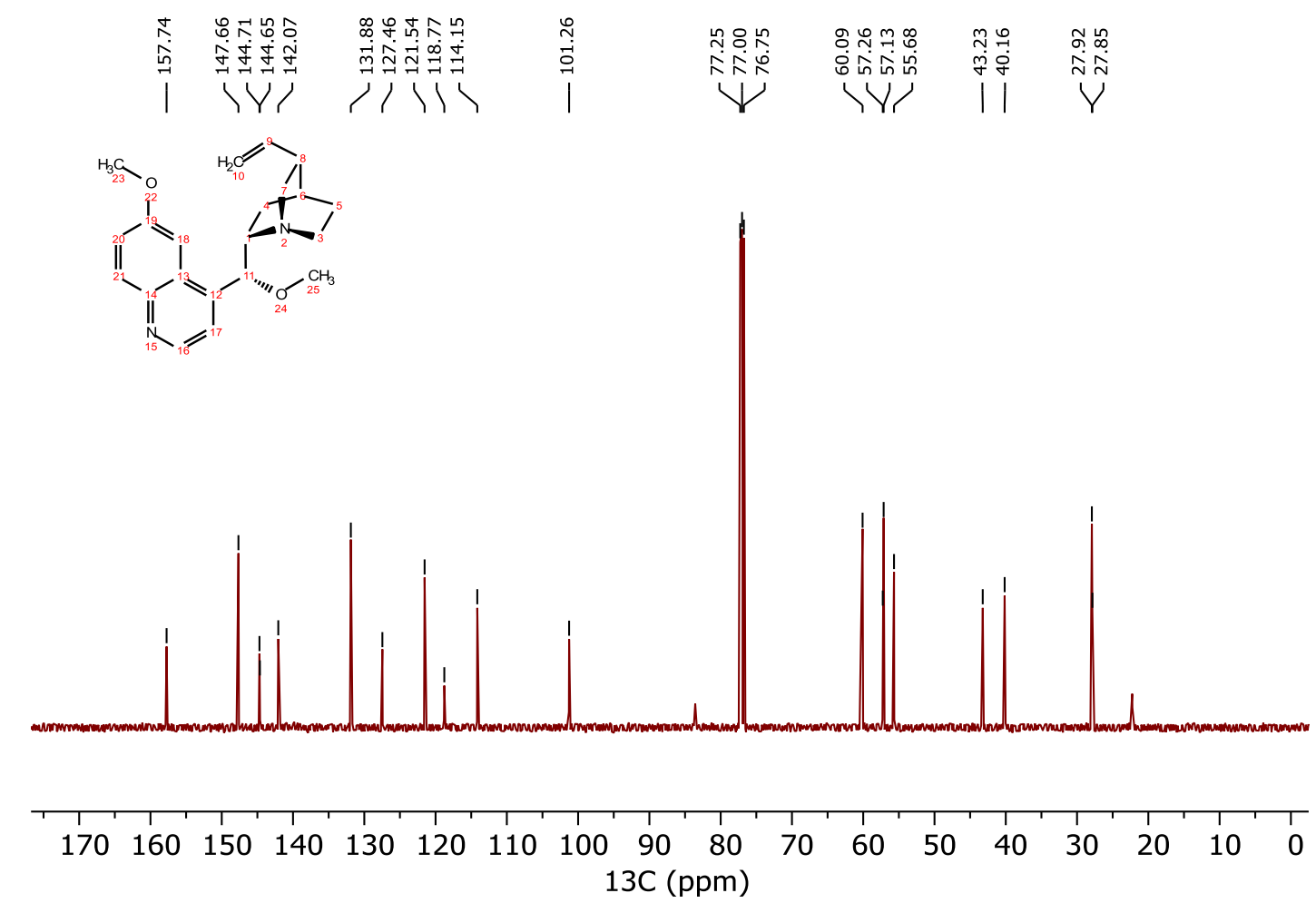

Figure S15. ${ }^{13} \mathrm{C}\left\{{ }^{1} \mathrm{H}\right\}$ NMR $(126 \mathrm{MHz})$ spectrum of $\mathbf{Q 3}$ in $\mathrm{CDCl}_{3}$. 


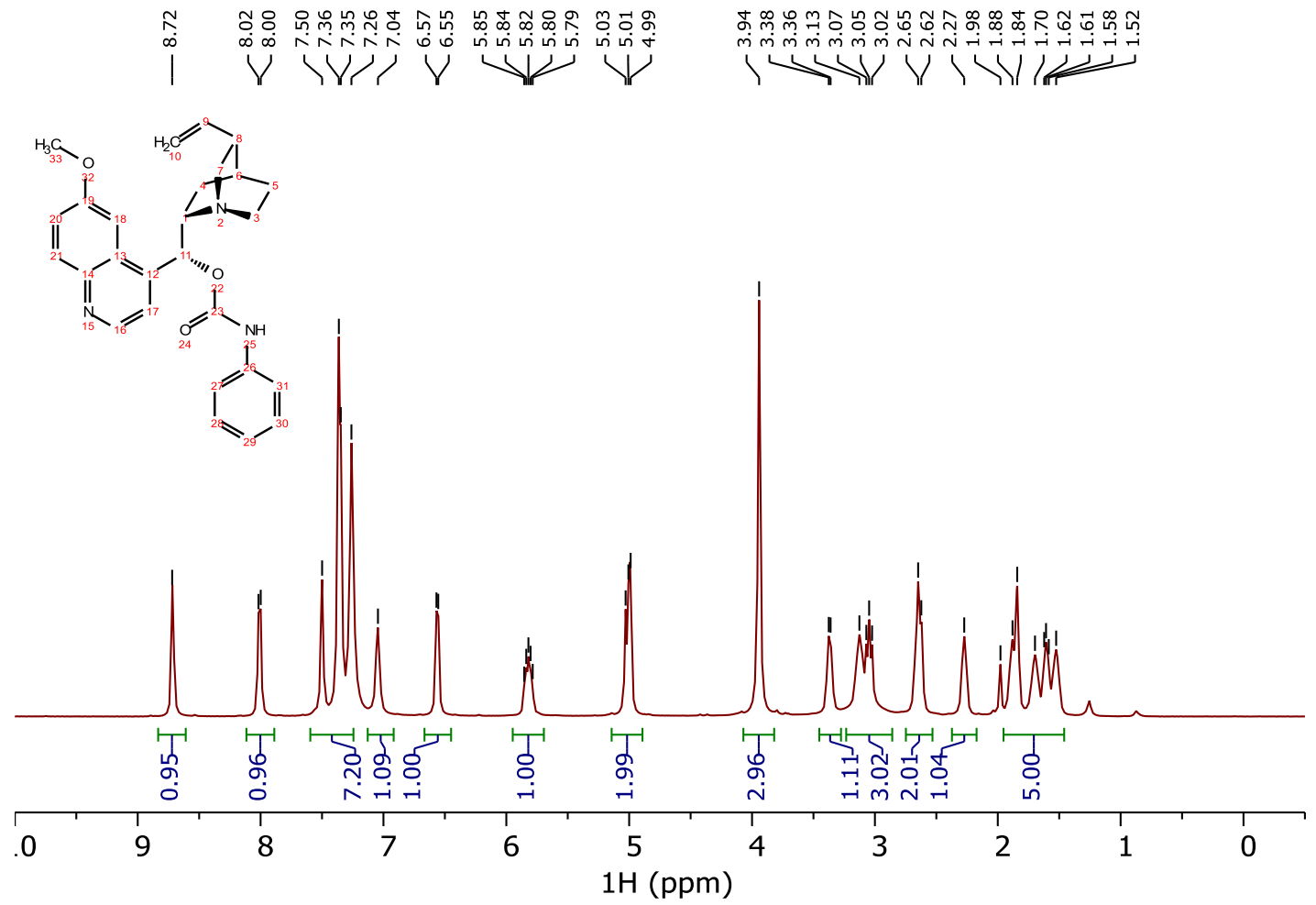

Figure S16. ${ }^{1} \mathrm{H}$ NMR (500 MHz) spectrum of $\mathbf{Q} 4$ in $\mathrm{CDCl}_{3}$.

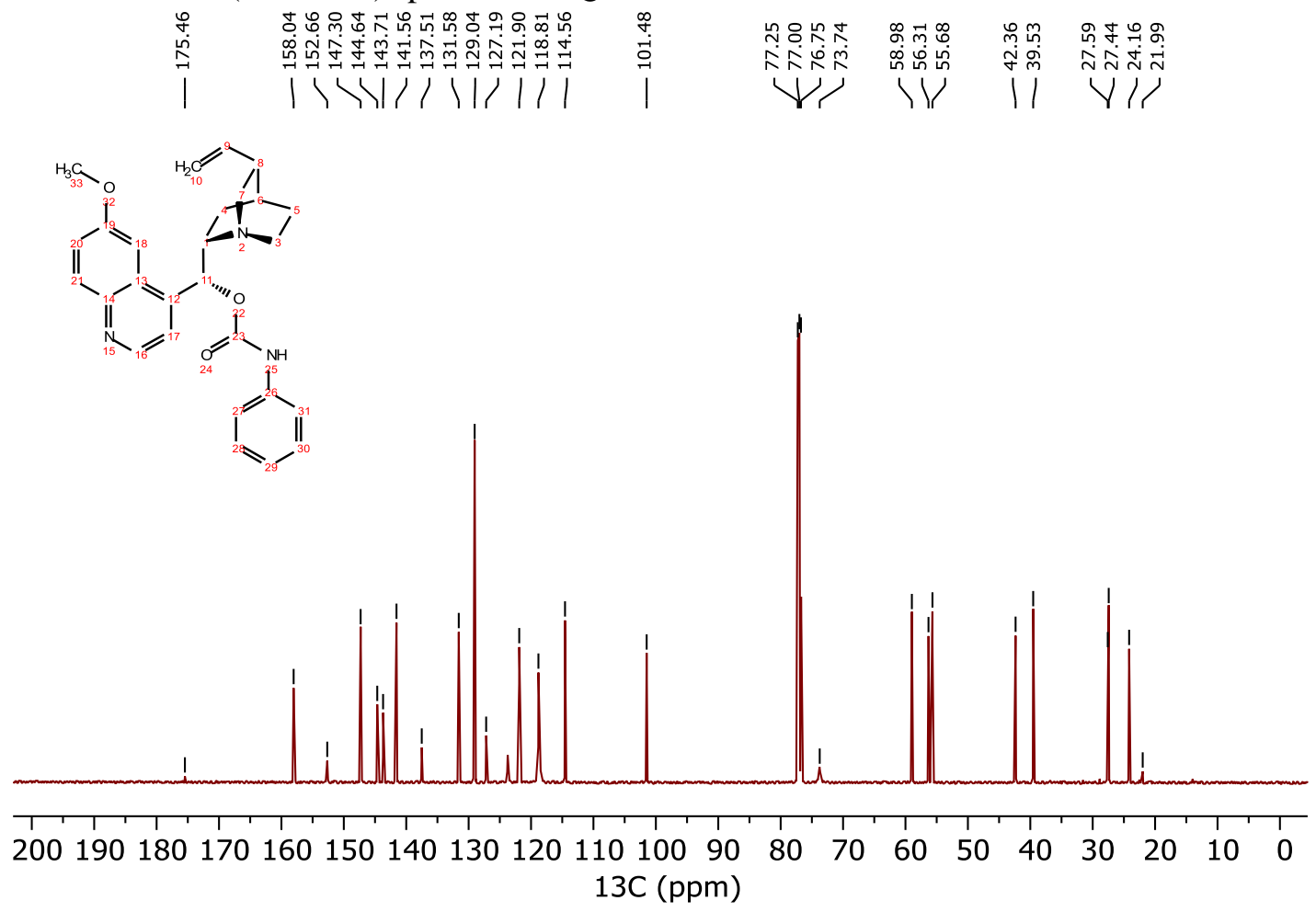

Figure S17. ${ }^{13} \mathrm{C}\left\{{ }^{1} \mathrm{H}\right\}$ NMR $(126 \mathrm{MHz})$ spectrum of $\mathbf{Q} 4$ in $\mathrm{CDCl}_{3}$. 


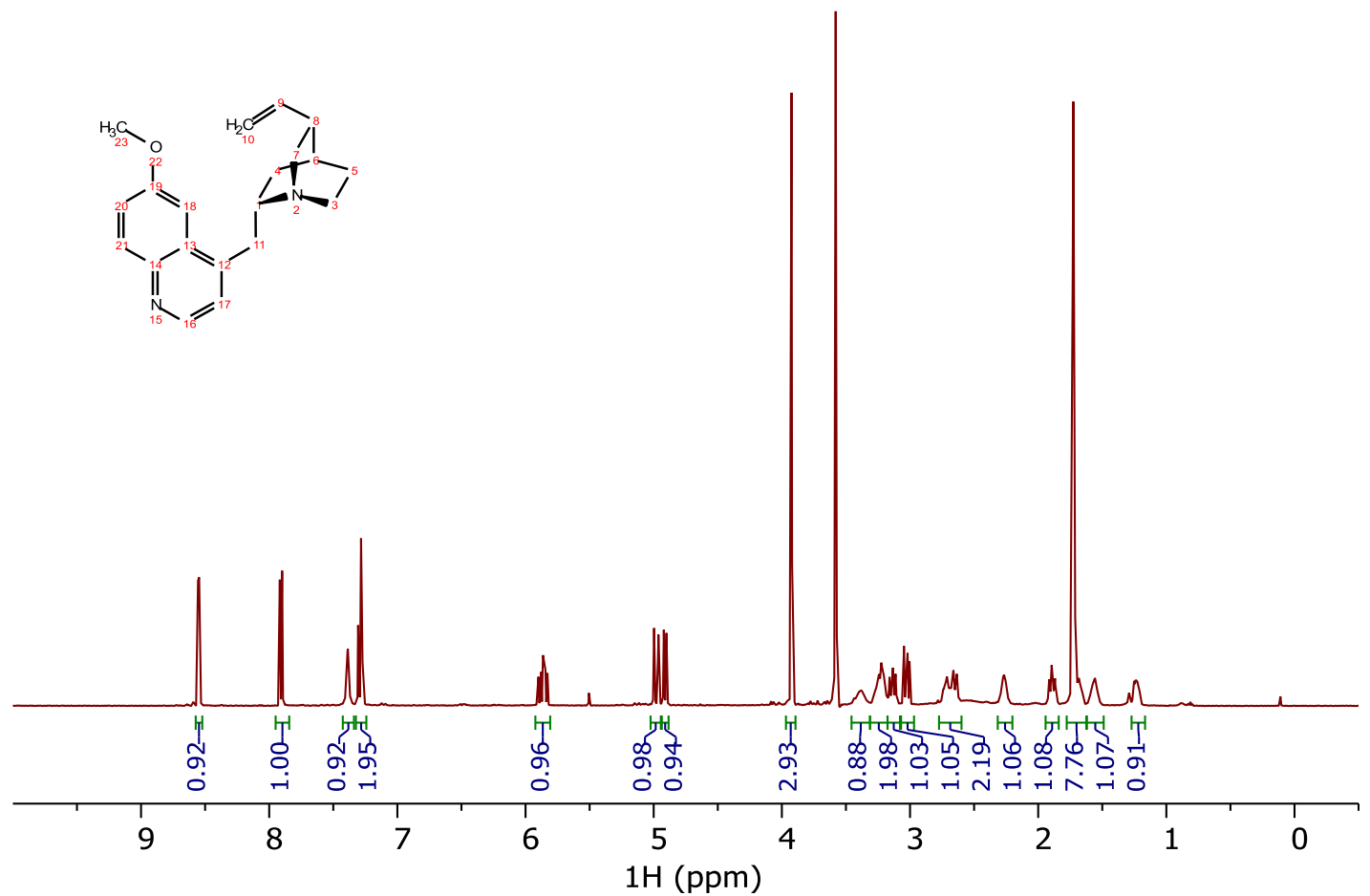

Figure S18. ${ }^{1} \mathrm{H}$ NMR $(500 \mathrm{MHz})$ spectrum of $\mathbf{Q 5}$ in $d_{8}$-THF.

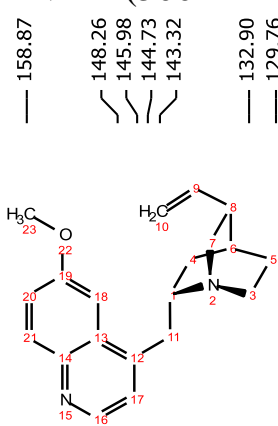
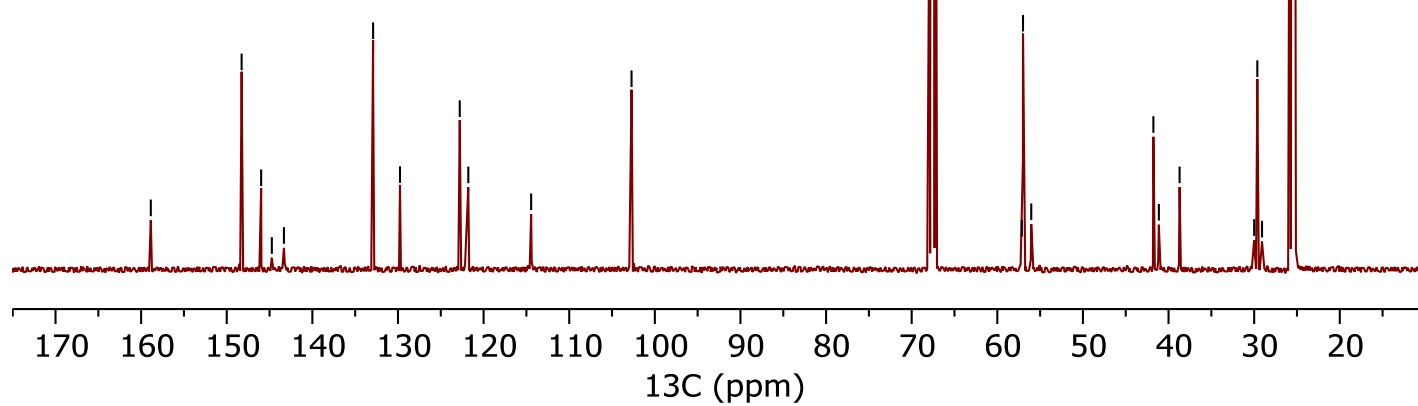

Figure S19. ${ }^{13} \mathrm{C}\left\{{ }^{1} \mathrm{H}\right\}$ NMR $(126 \mathrm{MHz})$ spectrum of $\mathbf{Q 5}$ in $d_{8}$-THF. 


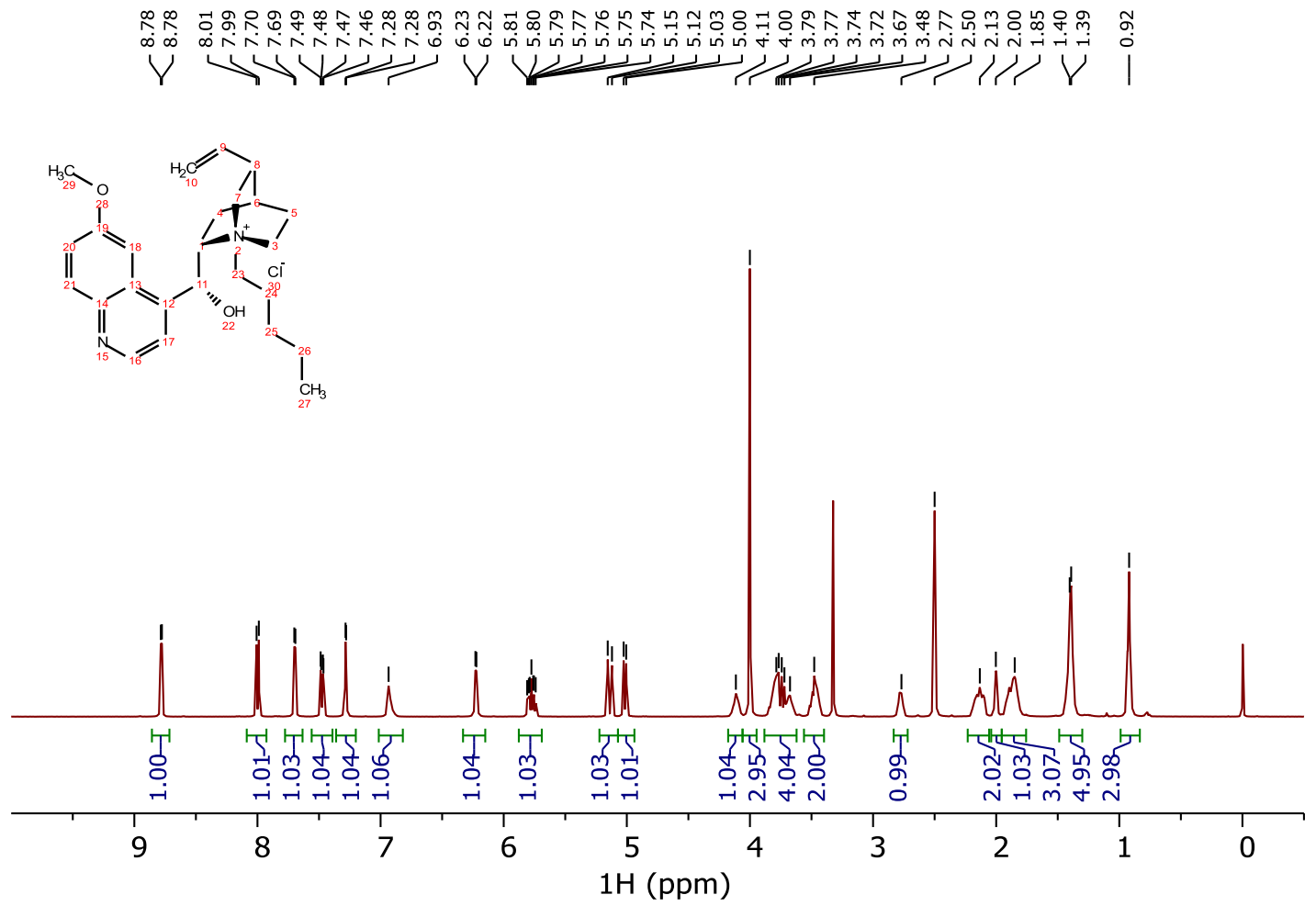

Figure S20. ${ }^{1} \mathrm{H}$ NMR $(500 \mathrm{MHz})$ spectrum of Q6 in DMSO- $d_{6}$.
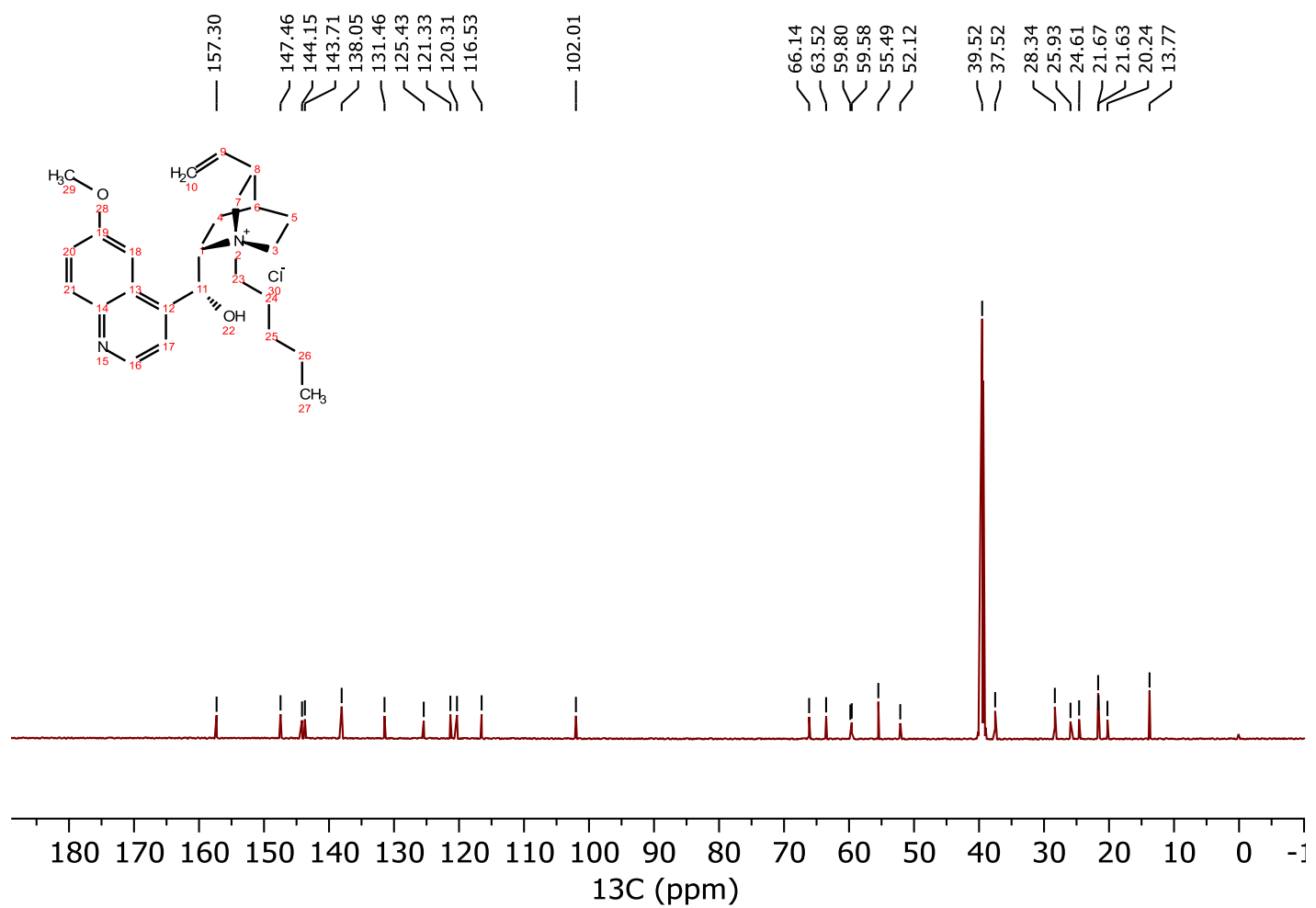

Figure S21. ${ }^{13} \mathrm{C}\left\{{ }^{1} \mathrm{H}\right\}$ NMR $(126 \mathrm{MHz})$ spectrum of Q6 in DMSO- $d_{6}$. 


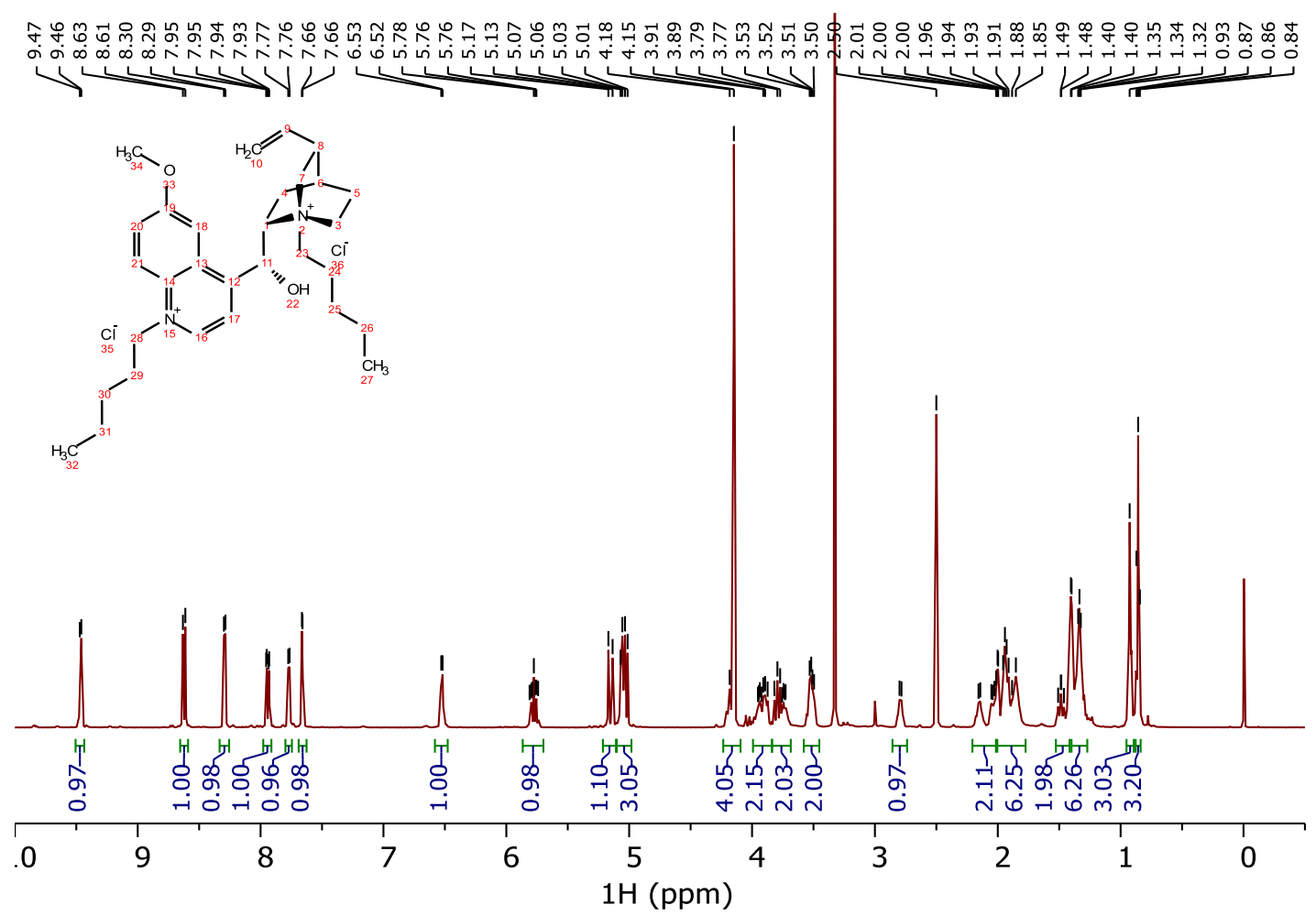

Figure S22. ${ }^{1} \mathrm{H}$ NMR $(500 \mathrm{MHz})$ spectrum of $\mathbf{Q} 7$ in DMSO- $d_{6}$.

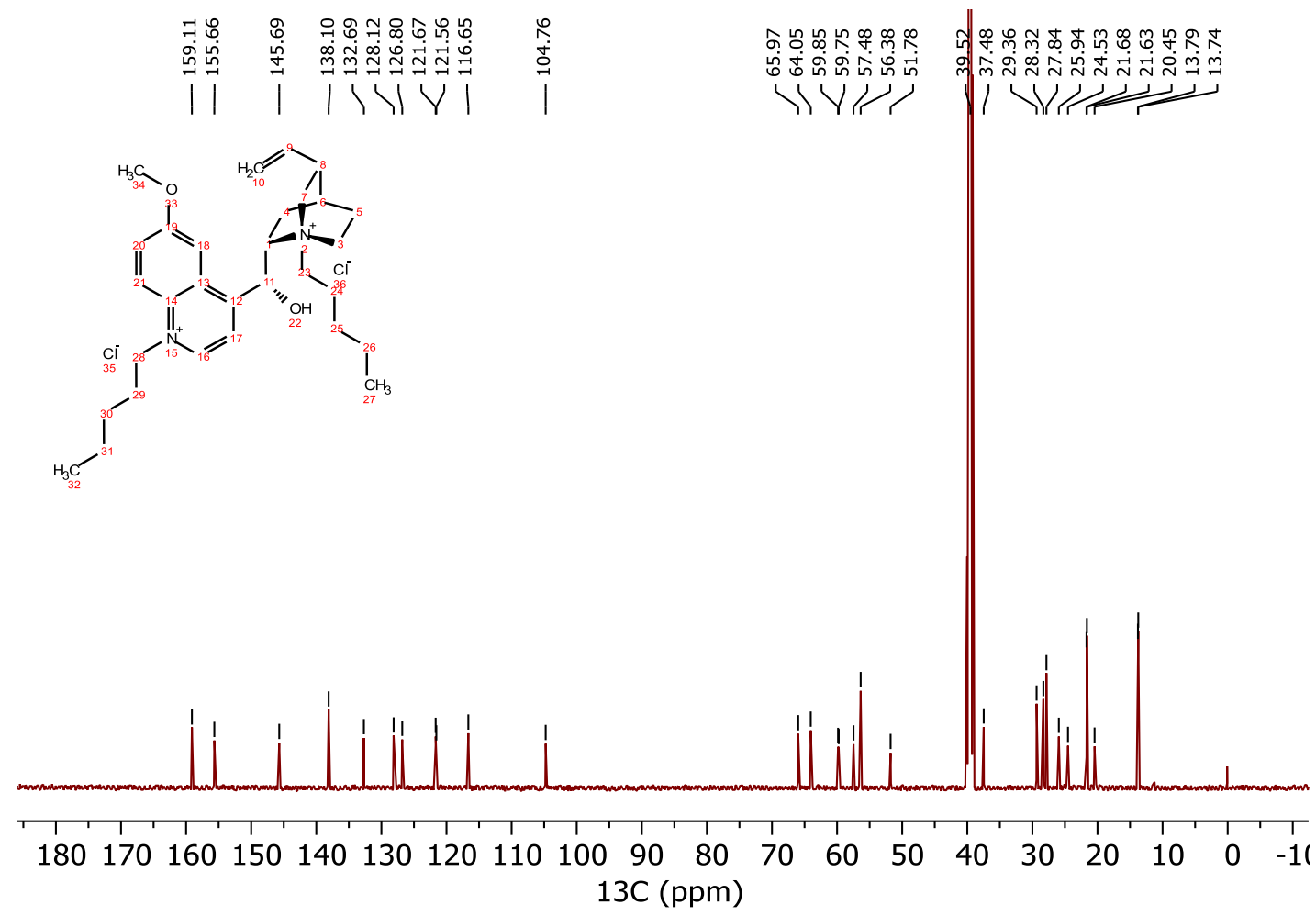

Figure S23. ${ }^{13} \mathrm{C}$ NMR $(125 \mathrm{MHz})$ spectrum of $\mathbf{Q 7}$ in DMSO- $d_{6}$. 


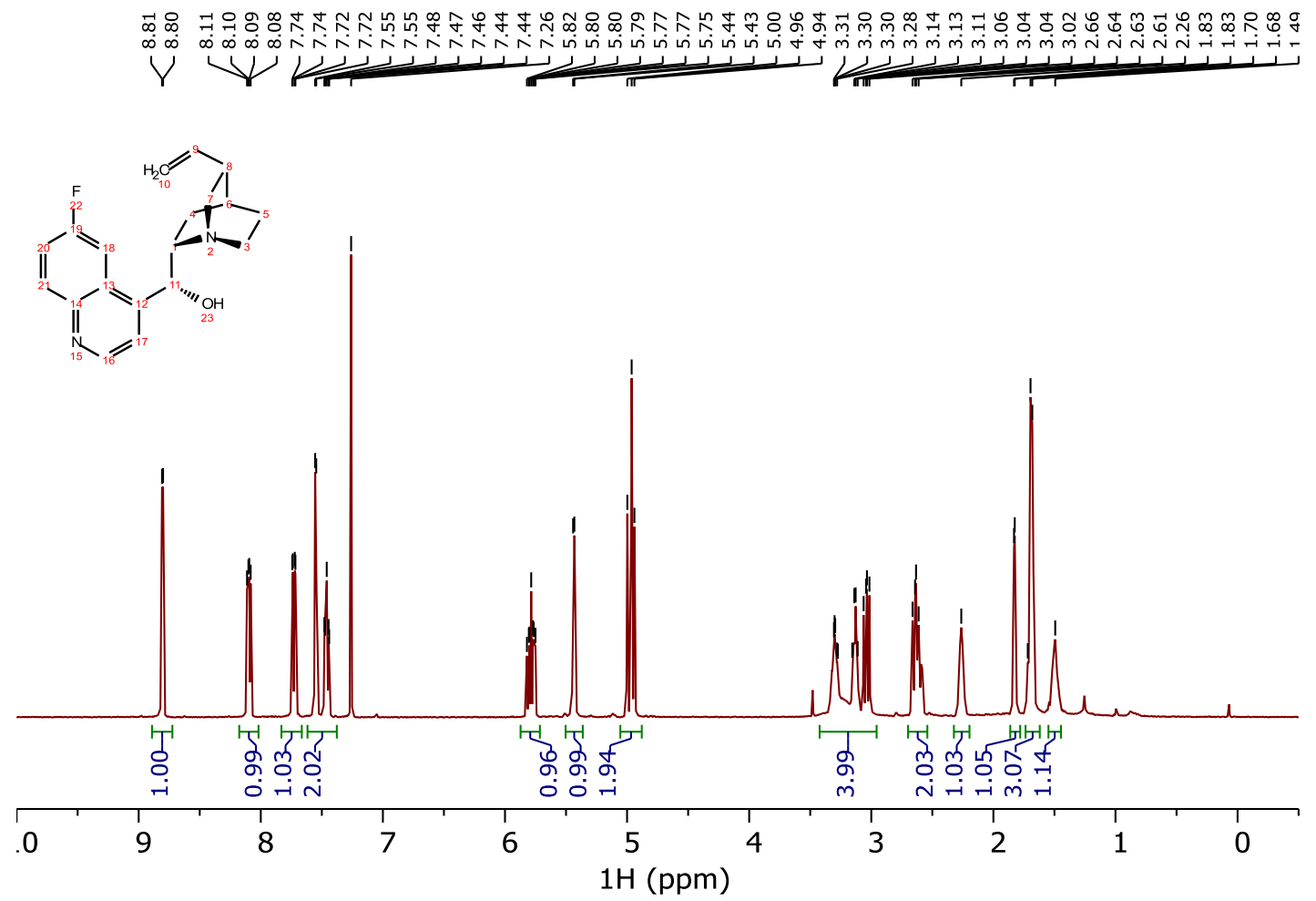

Figure S24. ${ }^{1} \mathrm{H}$ NMR (500 MHz) spectrum of $\mathbf{Q 8}$ in $\mathrm{CDCl}_{3}$.

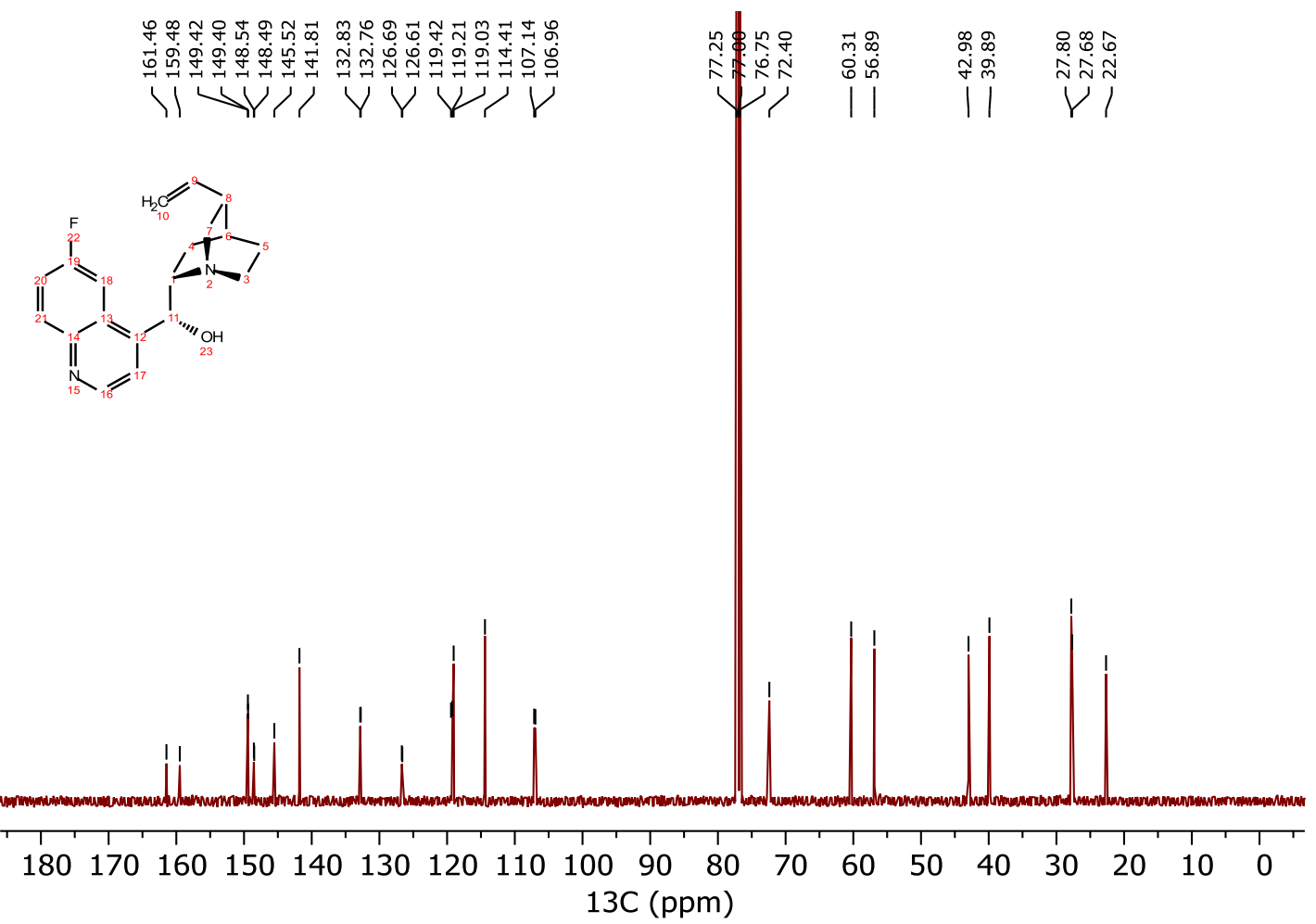

Figure S25. ${ }^{13} \mathrm{C}$ NMR (125 MHz) spectrum of $\mathbf{Q 8}$ in $\mathrm{CDCl}_{3}$. 


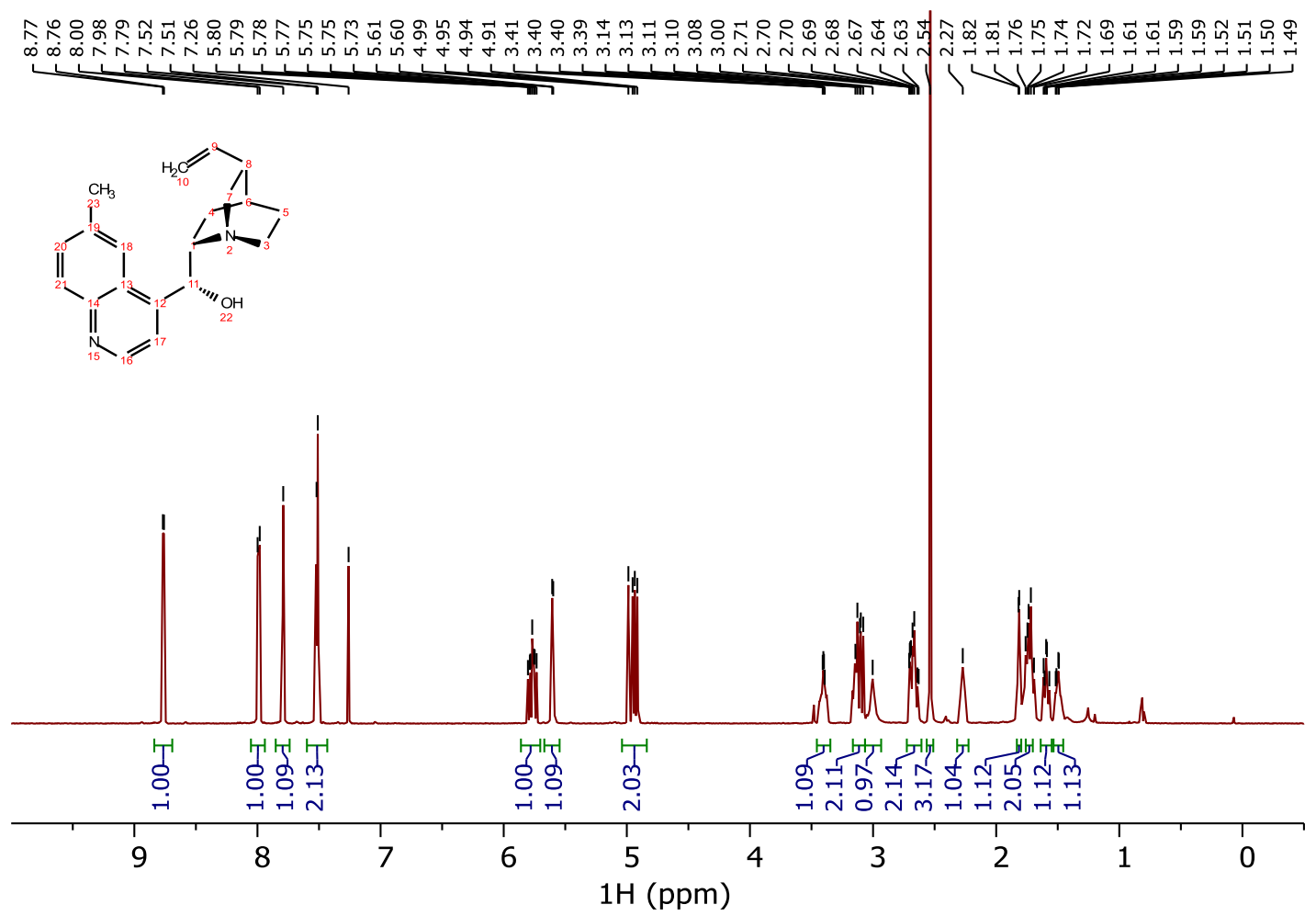

Figure S26. ${ }^{1} \mathrm{H}$ NMR $(500 \mathrm{MHz})$ spectrum of $\mathbf{Q 1 0}$ in $\mathrm{CDCl}_{3}$.
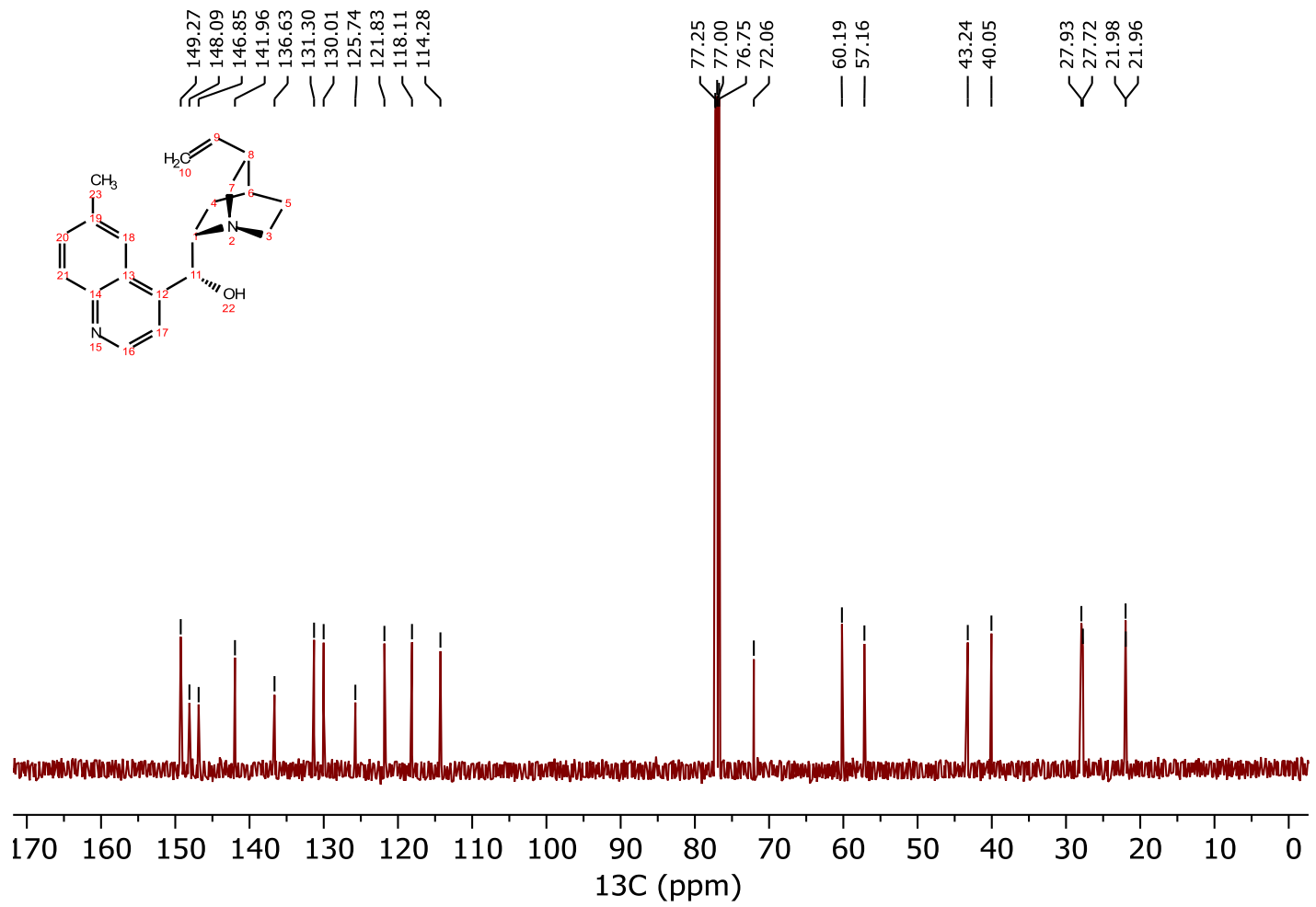

Figure S27. ${ }^{13} \mathrm{C}$ NMR $(125 \mathrm{MHz})$ spectrum of $\mathbf{Q 1 0}$ in $\mathrm{CDCl}_{3}$. 


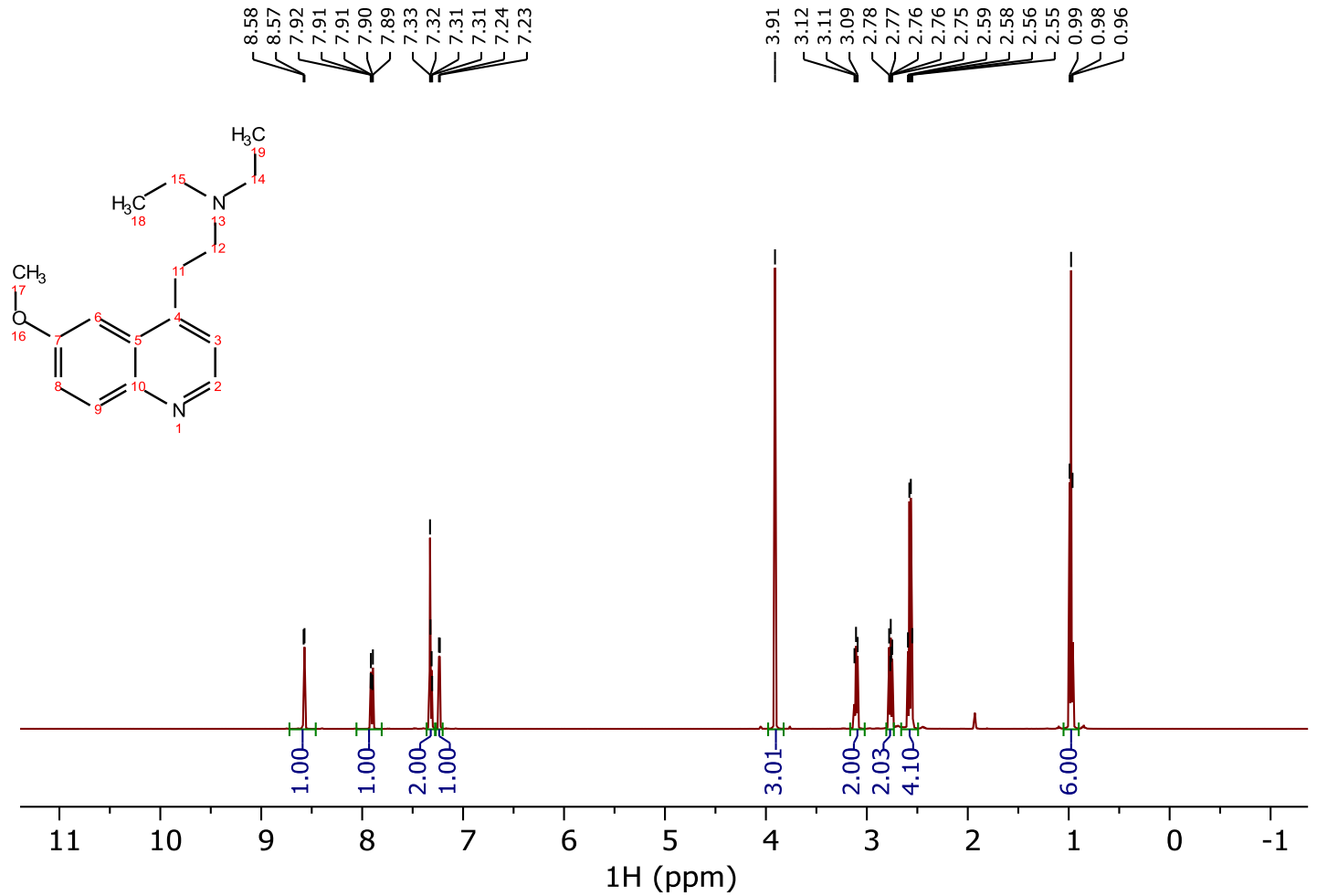

Figure S28. ${ }^{1} \mathrm{H}$ NMR $(500 \mathrm{MHz})$ spectrum of $\mathbf{Q 1 1}$ in $\mathrm{CD}_{3} \mathrm{CN}$.

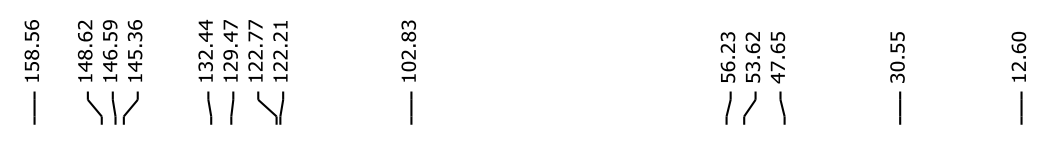<smiles>CCN(NCc1ccnc2ccc(OC)cc12)OC</smiles>

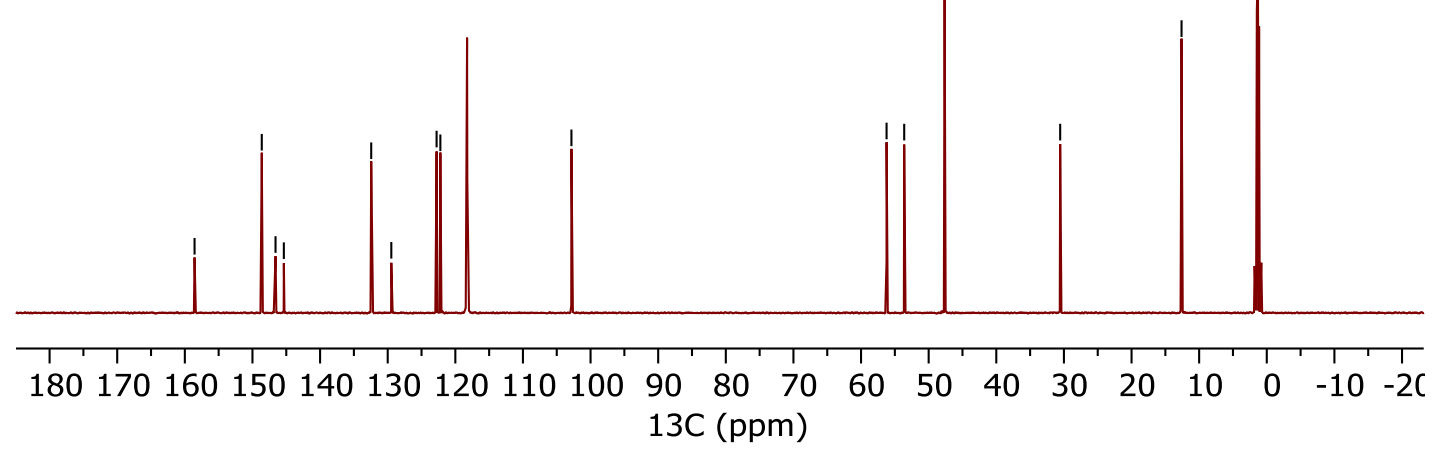

Figure S29. ${ }^{13} \mathrm{C}$ NMR (125 MHz) spectrum of $\mathbf{Q 1 1}$ in $\mathrm{CD}_{3} \mathrm{CN}$. 


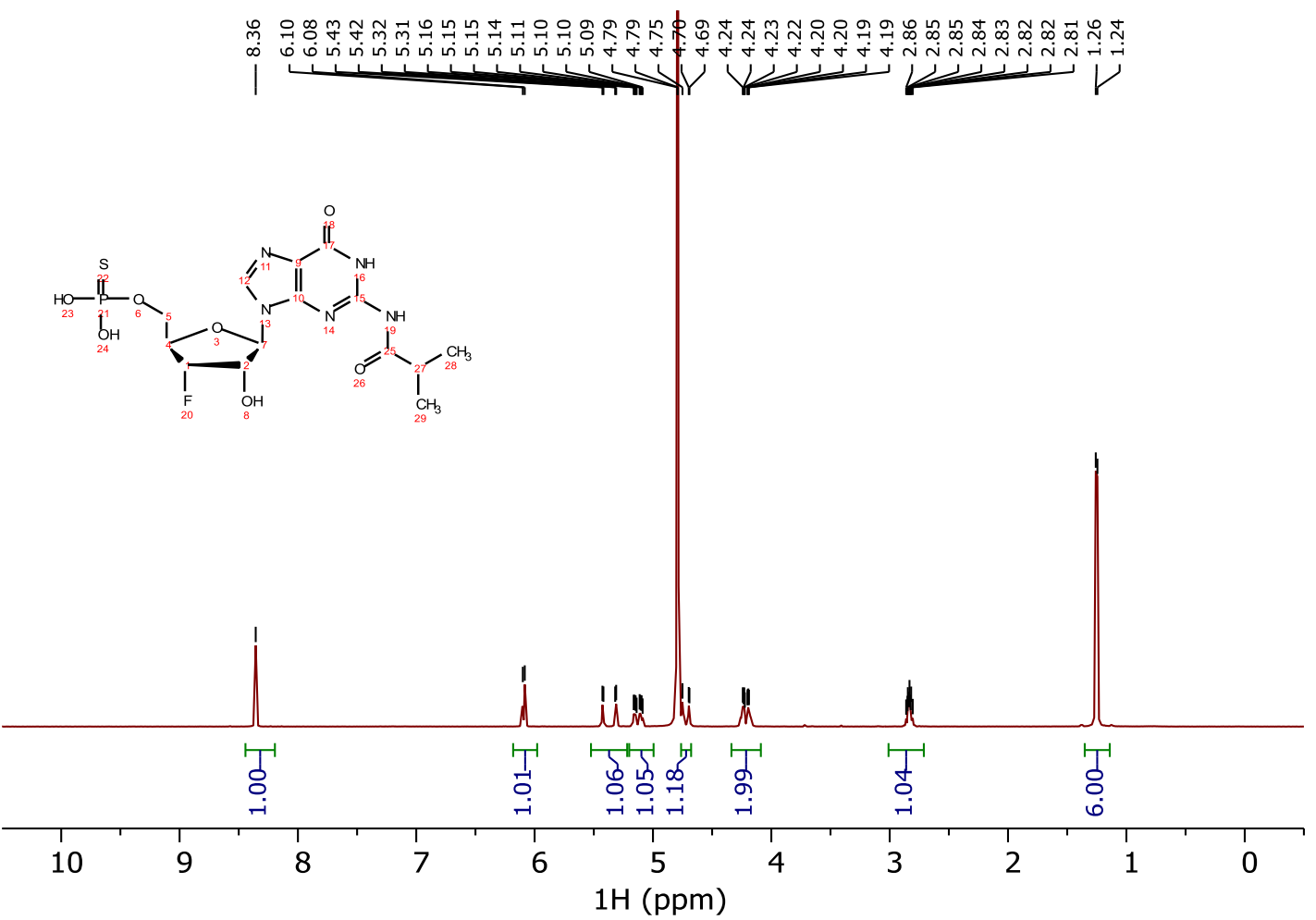

Figure S30. ${ }^{1} \mathrm{H}$ NMR $(500 \mathrm{MHz})$ spectrum of $\mathbf{1 b}$ in $\mathrm{D}_{2} \mathrm{O}$.
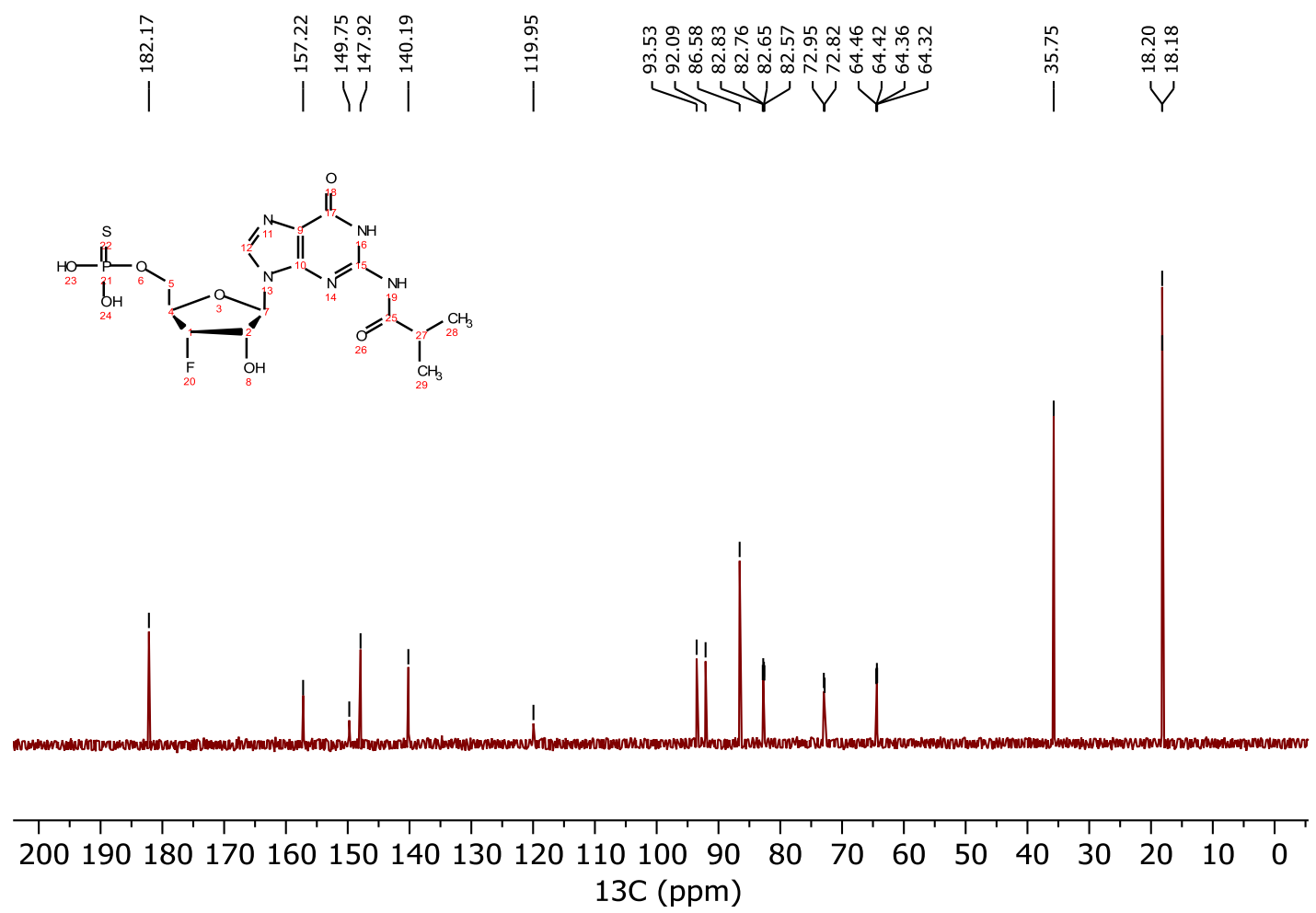

Figure S31. ${ }^{13} \mathrm{C}\left\{{ }^{1} \mathrm{H}\right\}$ NMR $(126 \mathrm{MHz})$ spectrum of $\mathbf{1 b}$ in $\mathrm{D}_{2} \mathrm{O}$. 


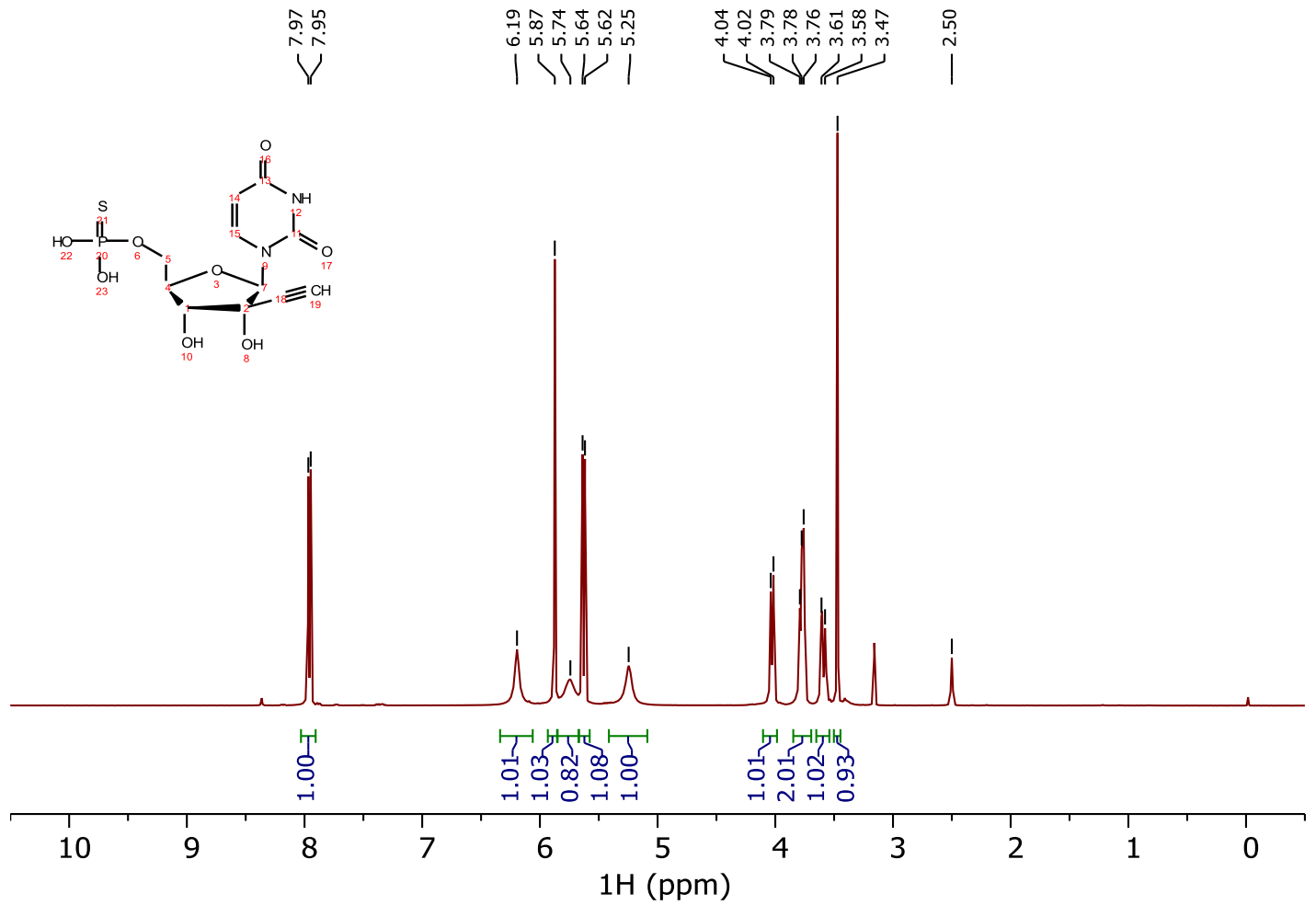

Figure S32. ${ }^{1} \mathrm{H}$ NMR $(400 \mathrm{MHz})$ spectrum of $\mathbf{2 b}$ in $d_{6}$-DMSO.

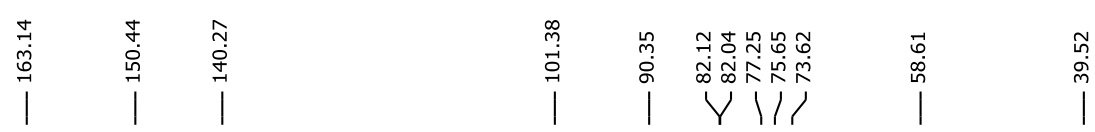

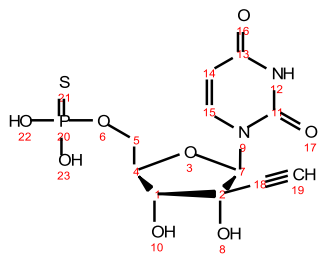
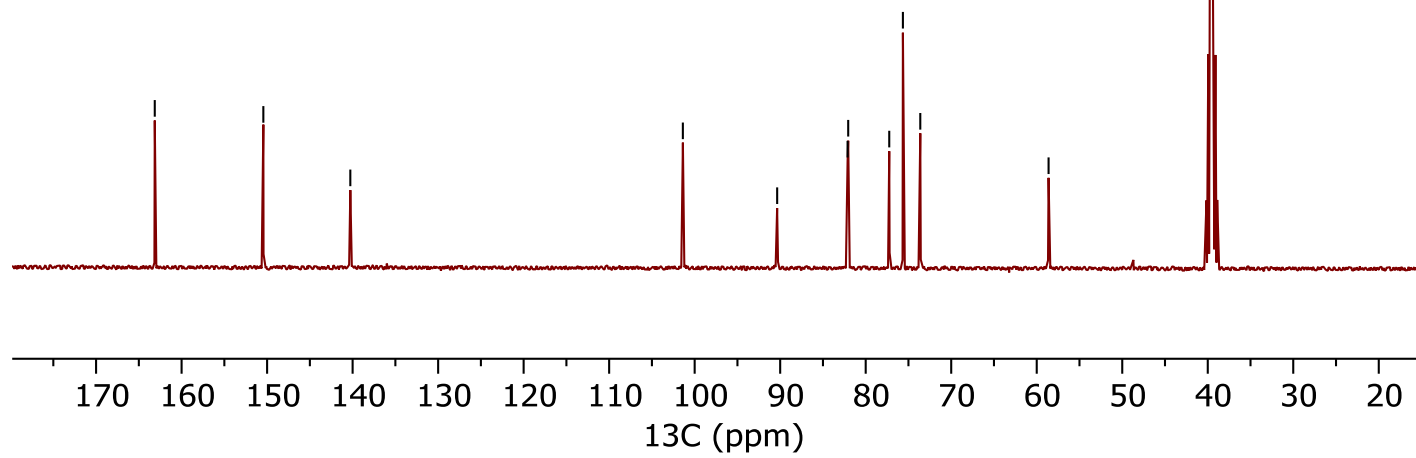

Figure S33. ${ }^{13} \mathrm{C}\left\{{ }^{1} \mathrm{H}\right\}$ NMR $(101 \mathrm{MHz})$ spectrum of $\mathbf{2 b}$ in $d_{6}$-DMSO. 


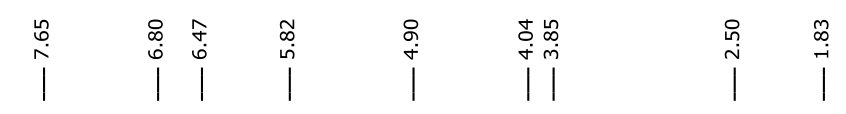
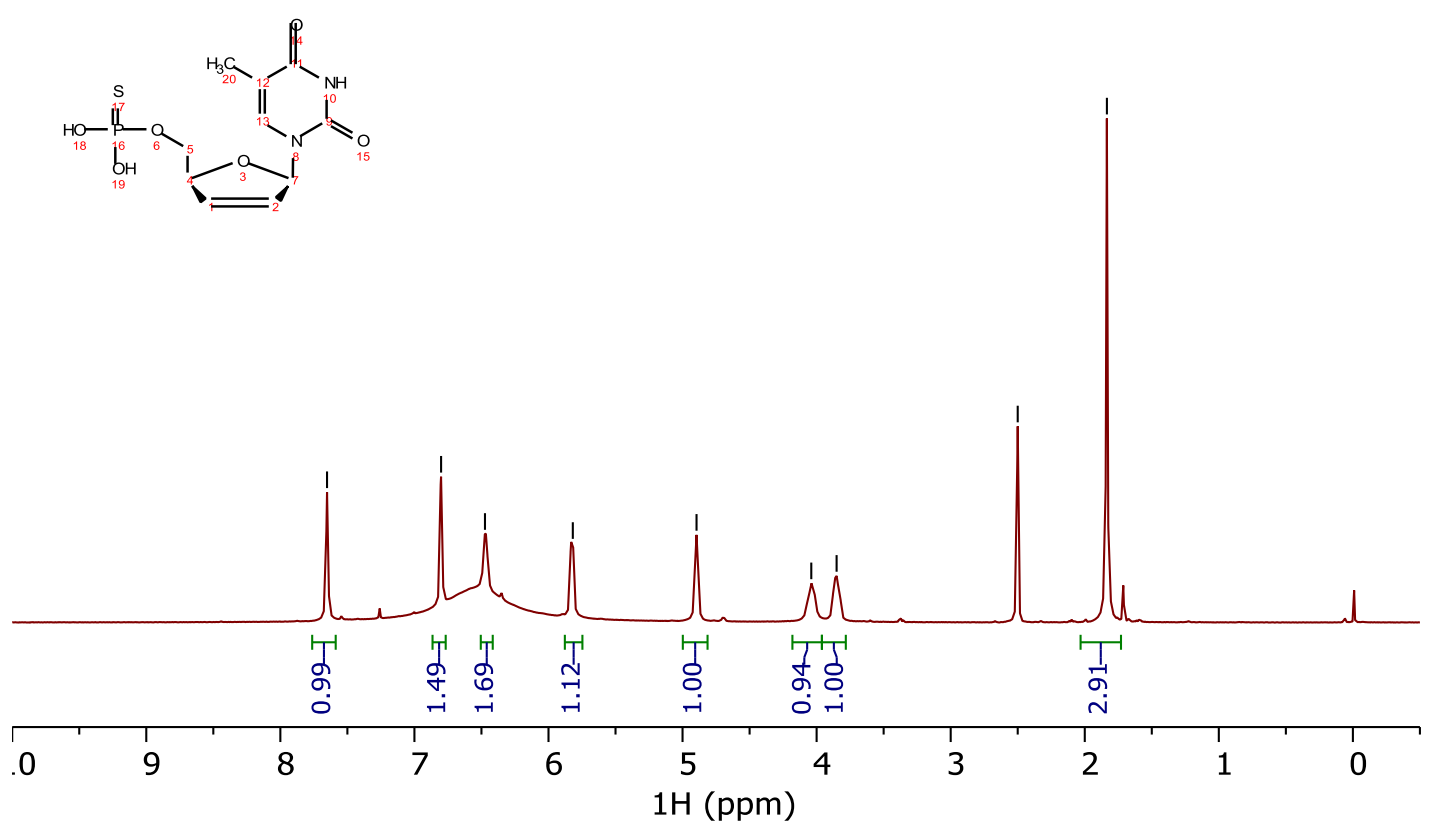

Figure S34. ${ }^{1} \mathrm{H}$ NMR $(400 \mathrm{MHz})$ spectrum of $\mathbf{3 b}$ in $d_{6}$-DMSO.

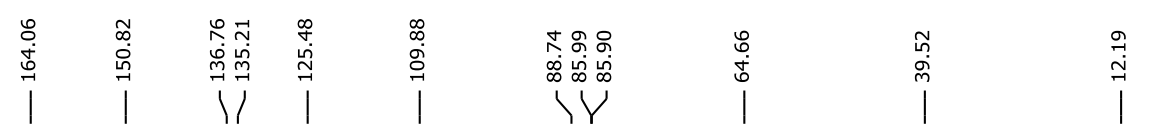
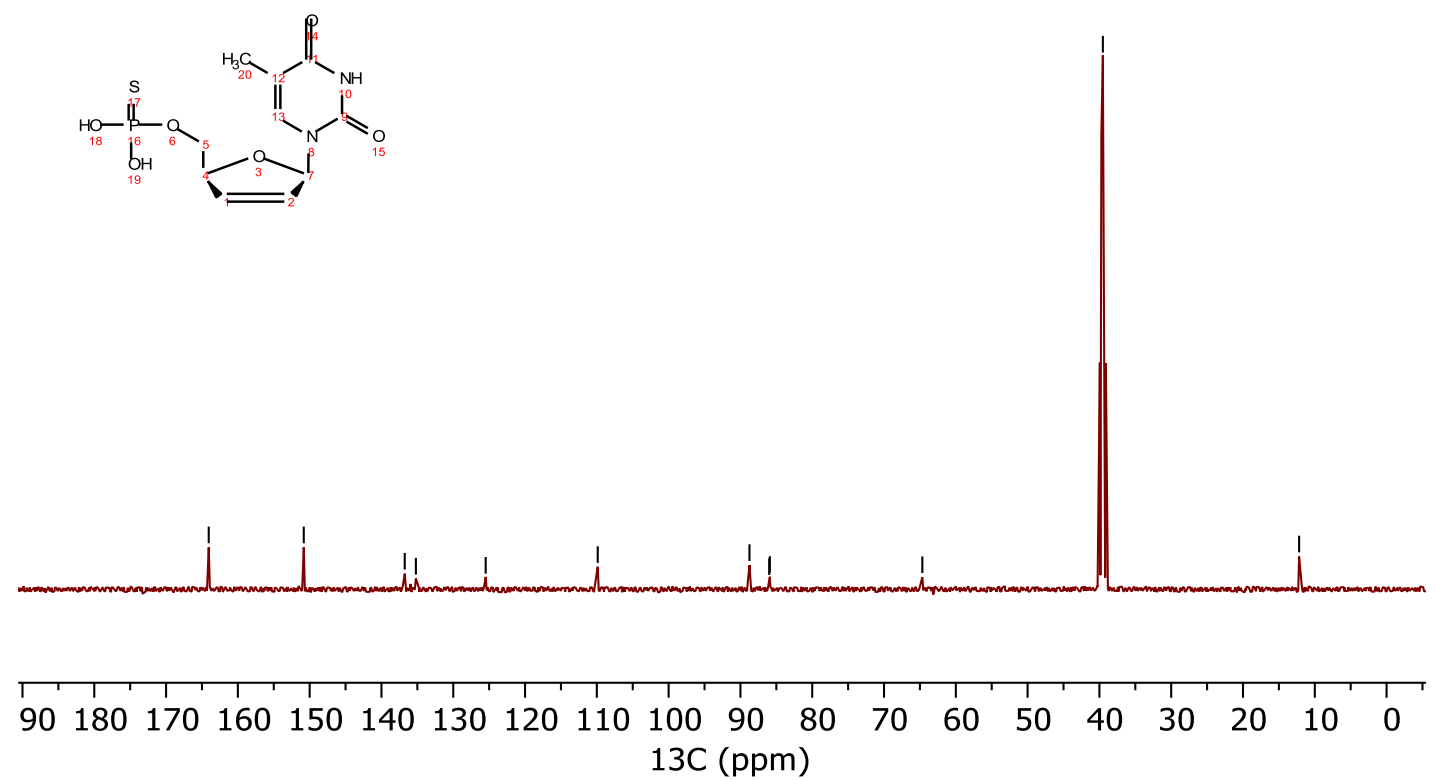

Figure S35. ${ }^{13} \mathrm{C}\left\{{ }^{1} \mathrm{H}\right\}$ NMR (101 MHz) spectrum of $\mathbf{3 b}$ in $d_{6}$-DMSO. 


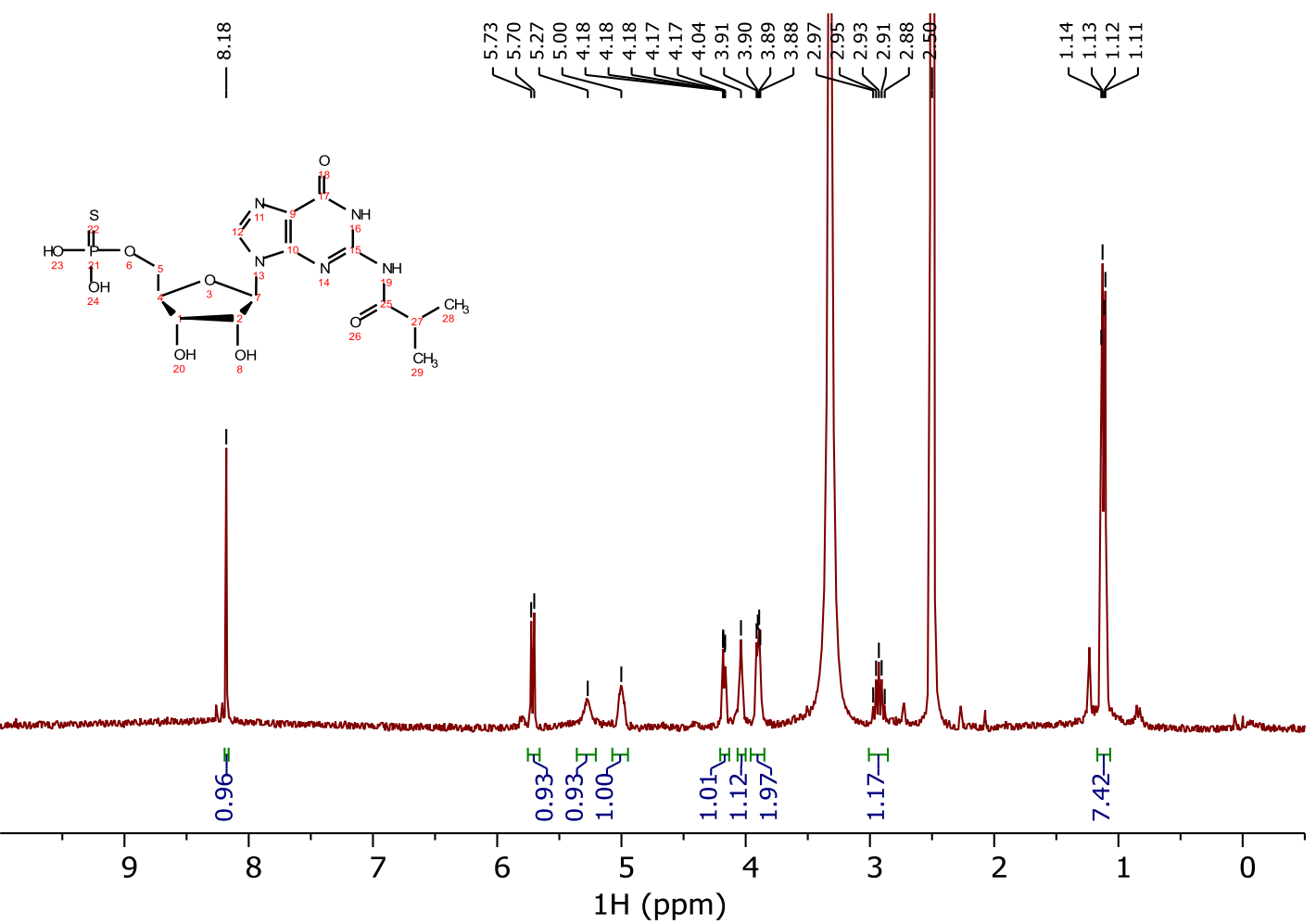

Figure S36. ${ }^{1} \mathrm{H}$ NMR $(300 \mathrm{MHz})$ spectrum of $\mathbf{4 b}$ in $d_{6}$-DMSO.

$\mid$

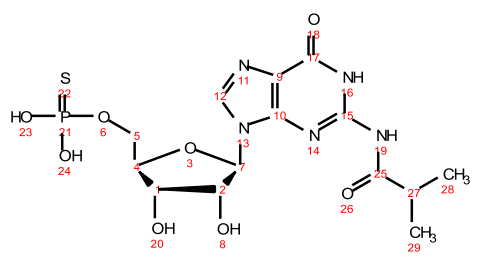

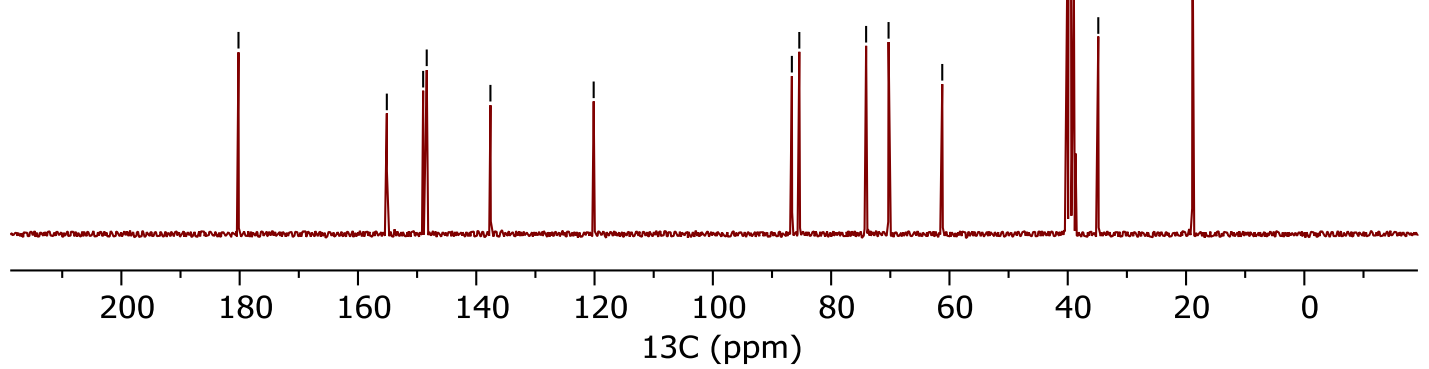

Figure S37. ${ }^{13} \mathrm{C}\left\{{ }^{1} \mathrm{H}\right\}$ NMR $(75 \mathrm{MHz})$ spectrum of $\mathbf{4 b}$ in $d_{6}$-DMSO. 


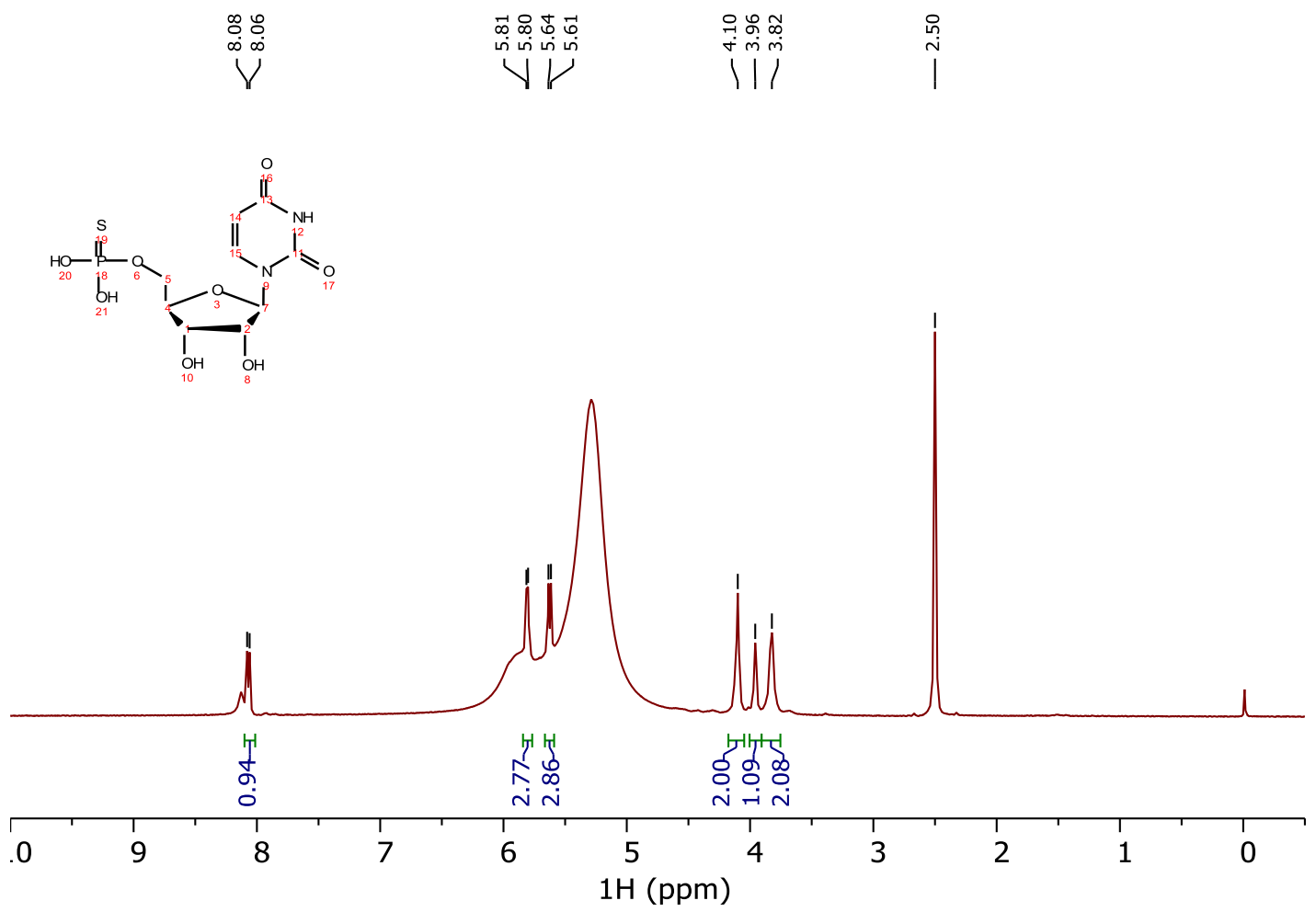

Figure S38. ${ }^{1} \mathrm{H}$ NMR (400 MHz) spectrum of $\mathbf{5 b}$ in $d_{6}$-DMSO.
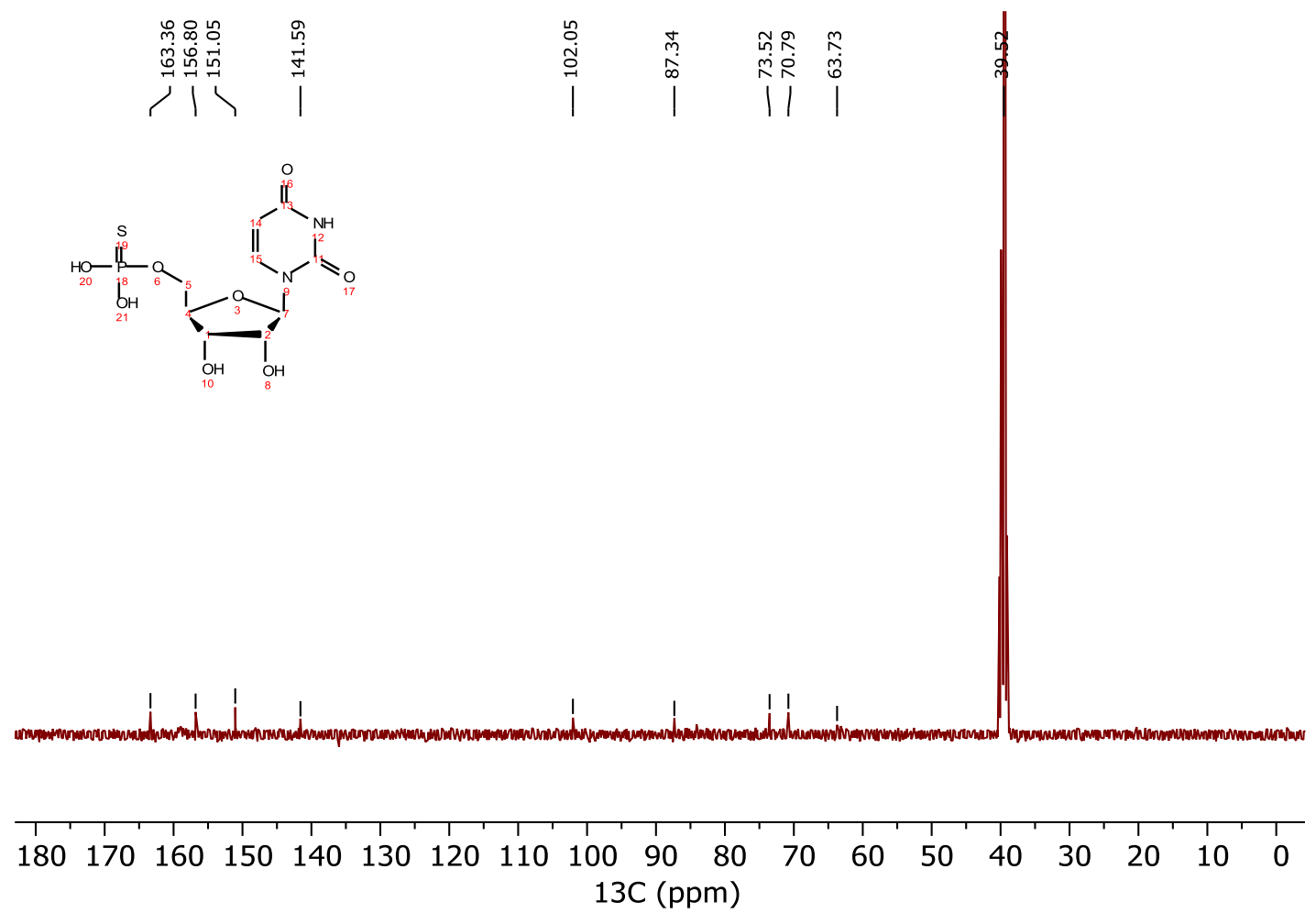

Figure S39. ${ }^{13} \mathrm{C}\left\{{ }^{1} \mathrm{H}\right\}$ NMR (101 MHz) spectrum of $\mathbf{5 b}$ in $d_{6}$-DMSO. 


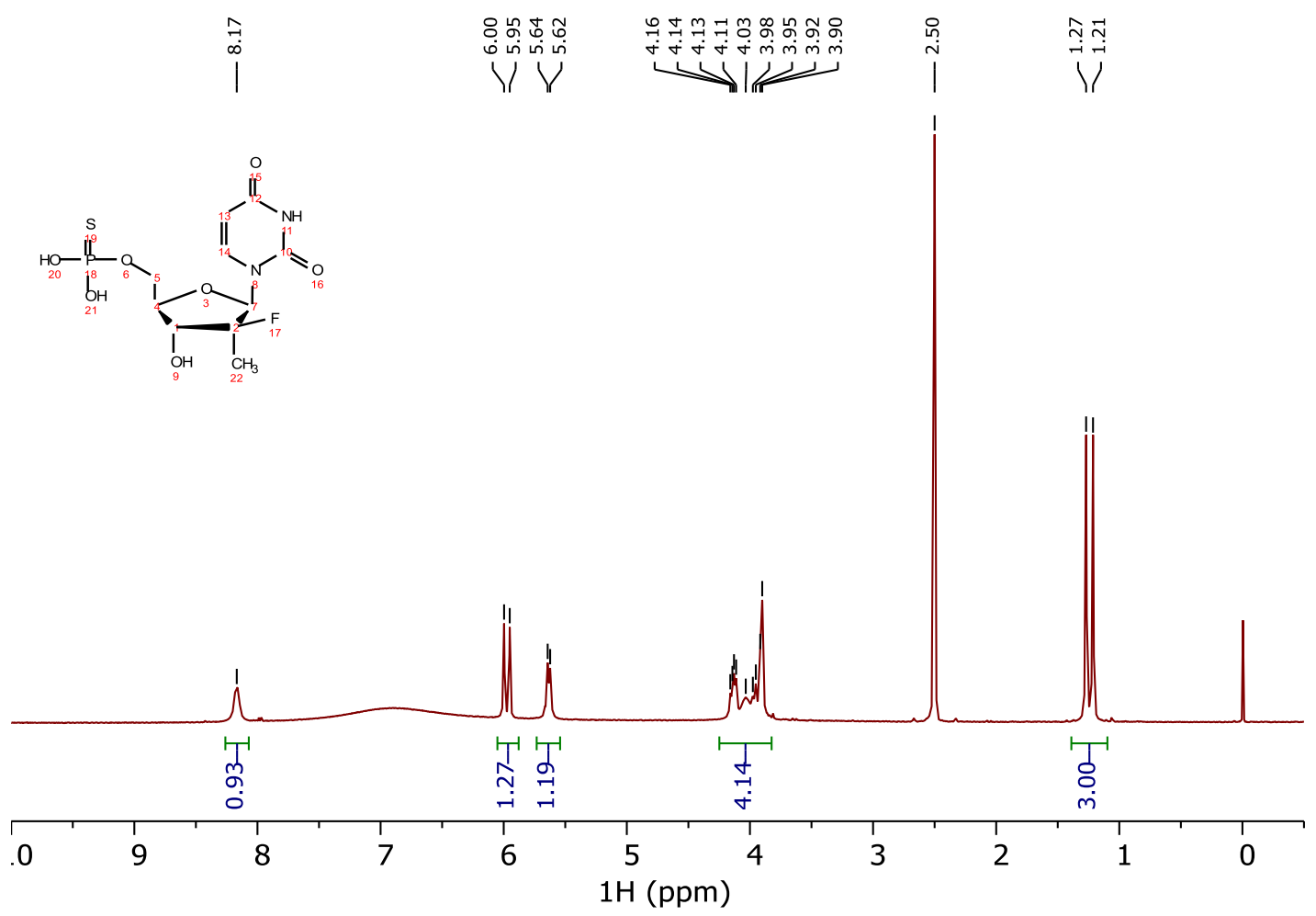

Figure S40. ${ }^{1} \mathrm{H}$ NMR (400 MHz) spectrum of $\mathbf{6 b}$ in $d_{6}$-DMSO.

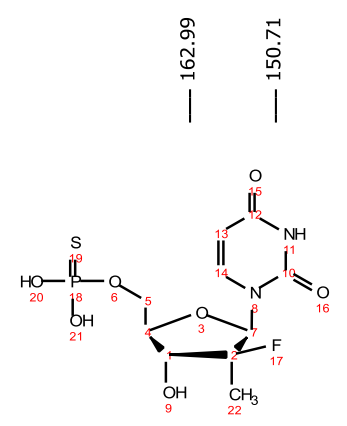

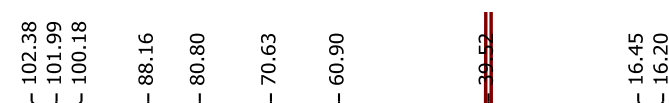

$$
\begin{aligned}
& \text { V) } 11111
\end{aligned}
$$
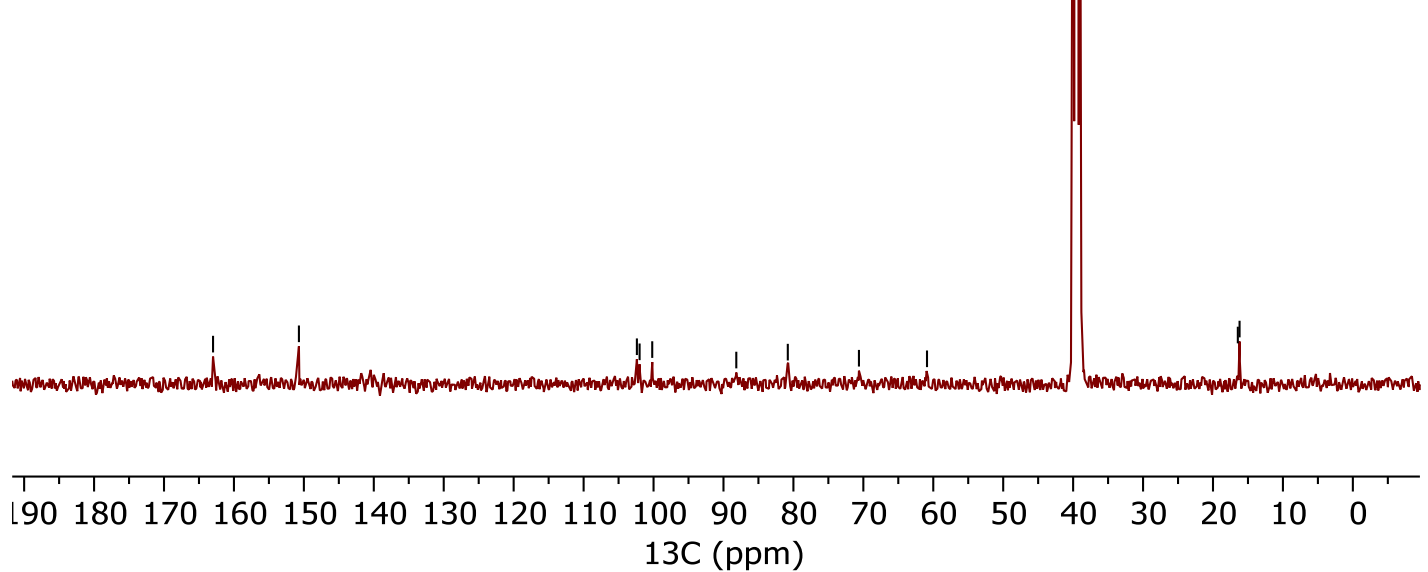

Figure S41. ${ }^{13} \mathrm{C}\left\{{ }^{1} \mathrm{H}\right\}$ NMR (101 MHz) spectrum of $\mathbf{6 b}$ in $d_{6}$-DMSO. 


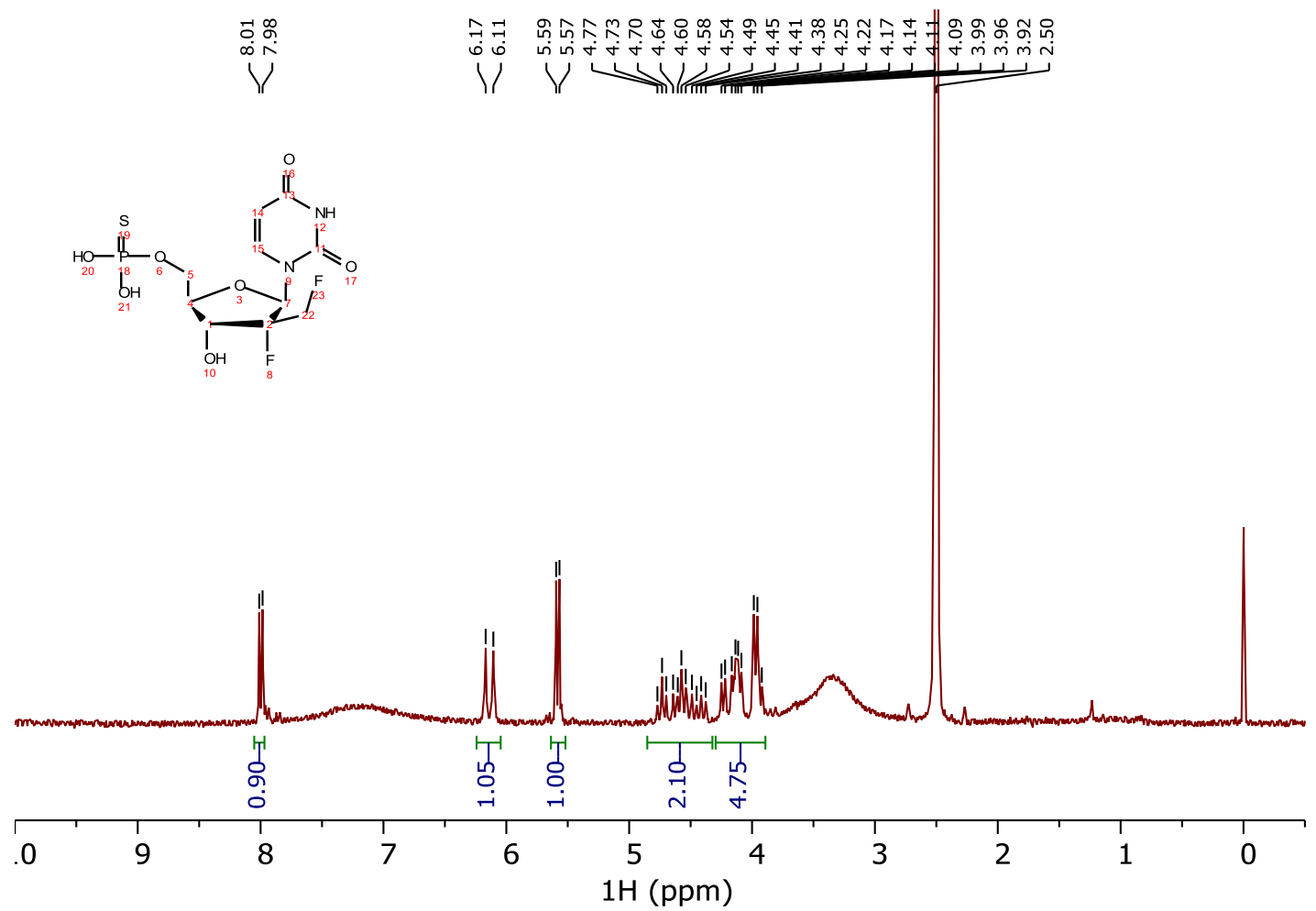

Figure S42. ${ }^{1} \mathrm{H}$ NMR $(300 \mathrm{MHz})$ spectrum of $\mathbf{7 b}$ in $d_{6}$-DMSO.

م
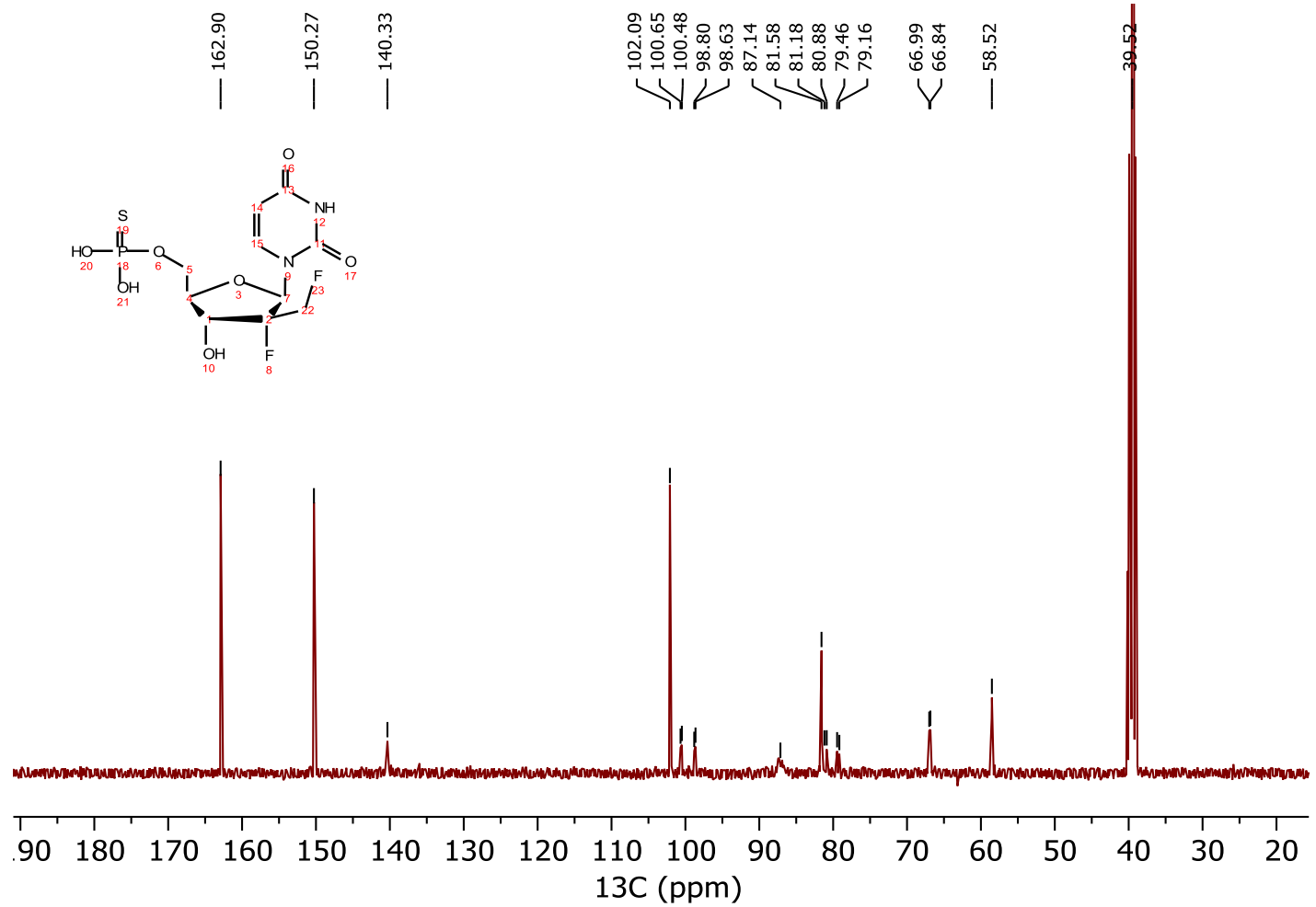

Figure S43. ${ }^{13} \mathrm{C}\left\{{ }^{1} \mathrm{H}\right\}$ NMR $(101 \mathrm{MHz})$ spectrum of $\mathbf{7 b}$ in $d_{6}$-DMSO. 


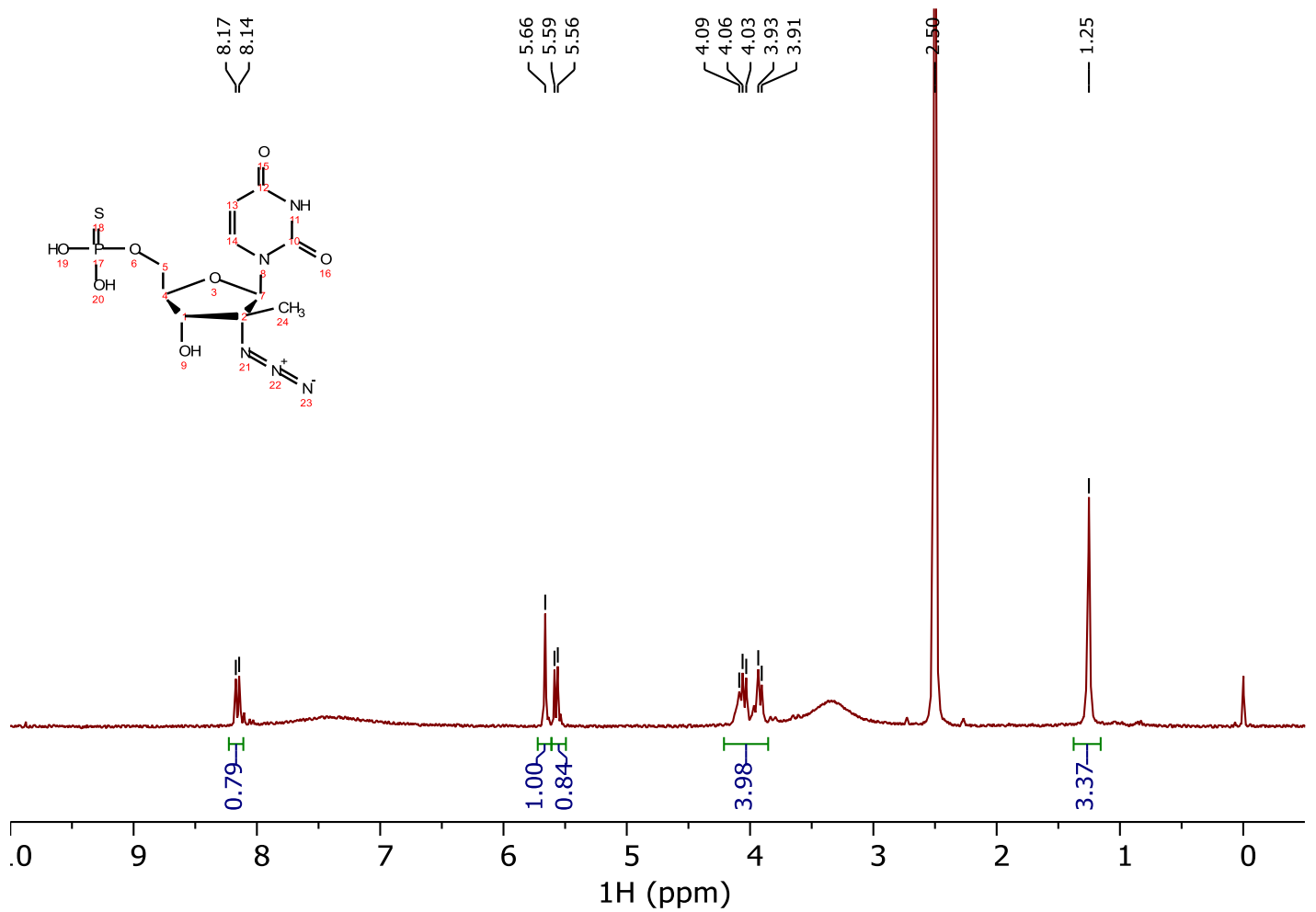

Figure S44. ${ }^{1} \mathrm{H}$ NMR $(300 \mathrm{MHz})$ spectrum of $8 \mathbf{b}$ in $d_{6}$-DMSO.

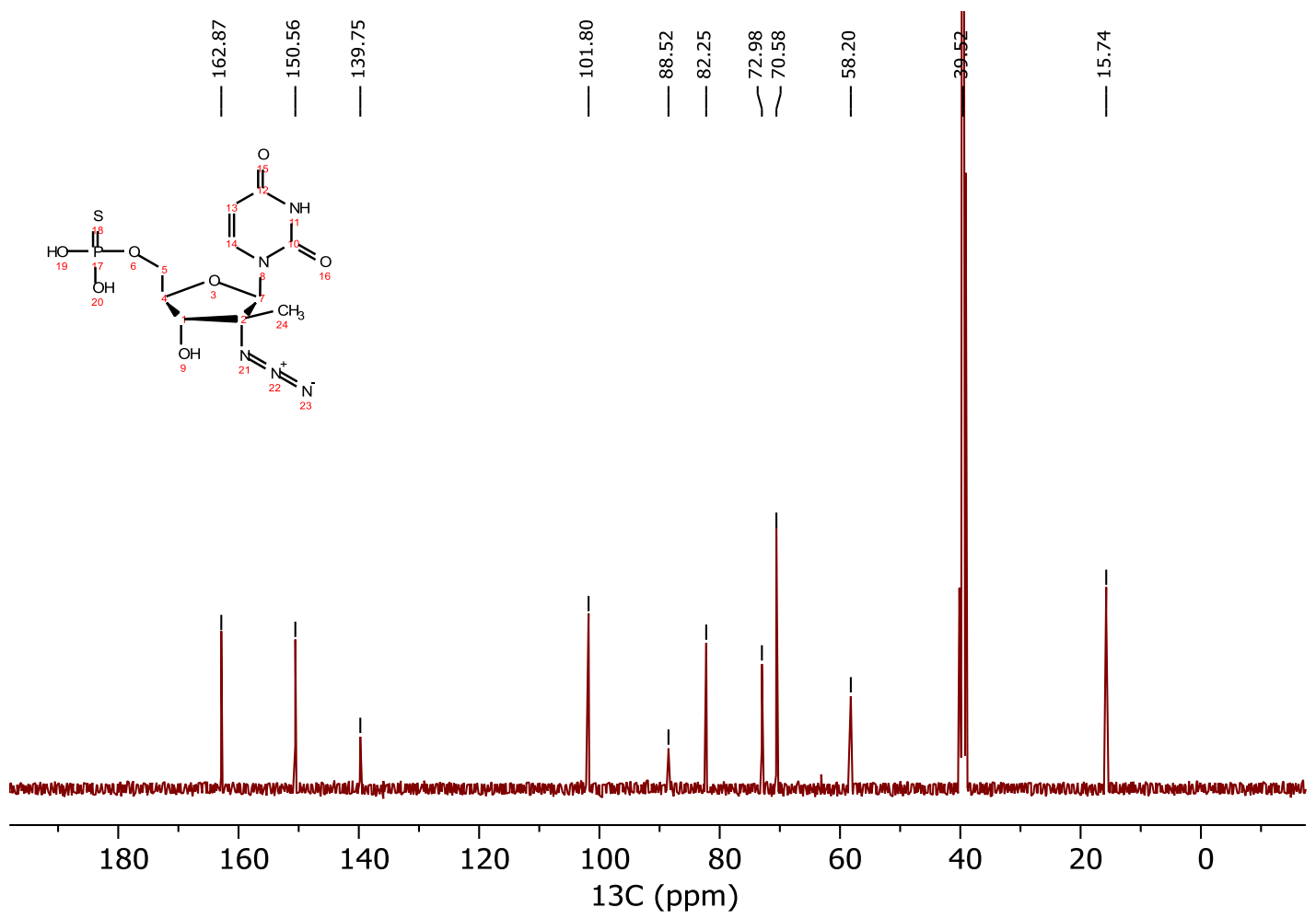

Figure $\mathbf{S 4 5} .{ }^{13} \mathrm{C}\left\{{ }^{1} \mathrm{H}\right\}$ NMR $(101 \mathrm{MHz})$ spectrum of $\mathbf{8 b}$ in $d_{6}$-DMSO. 


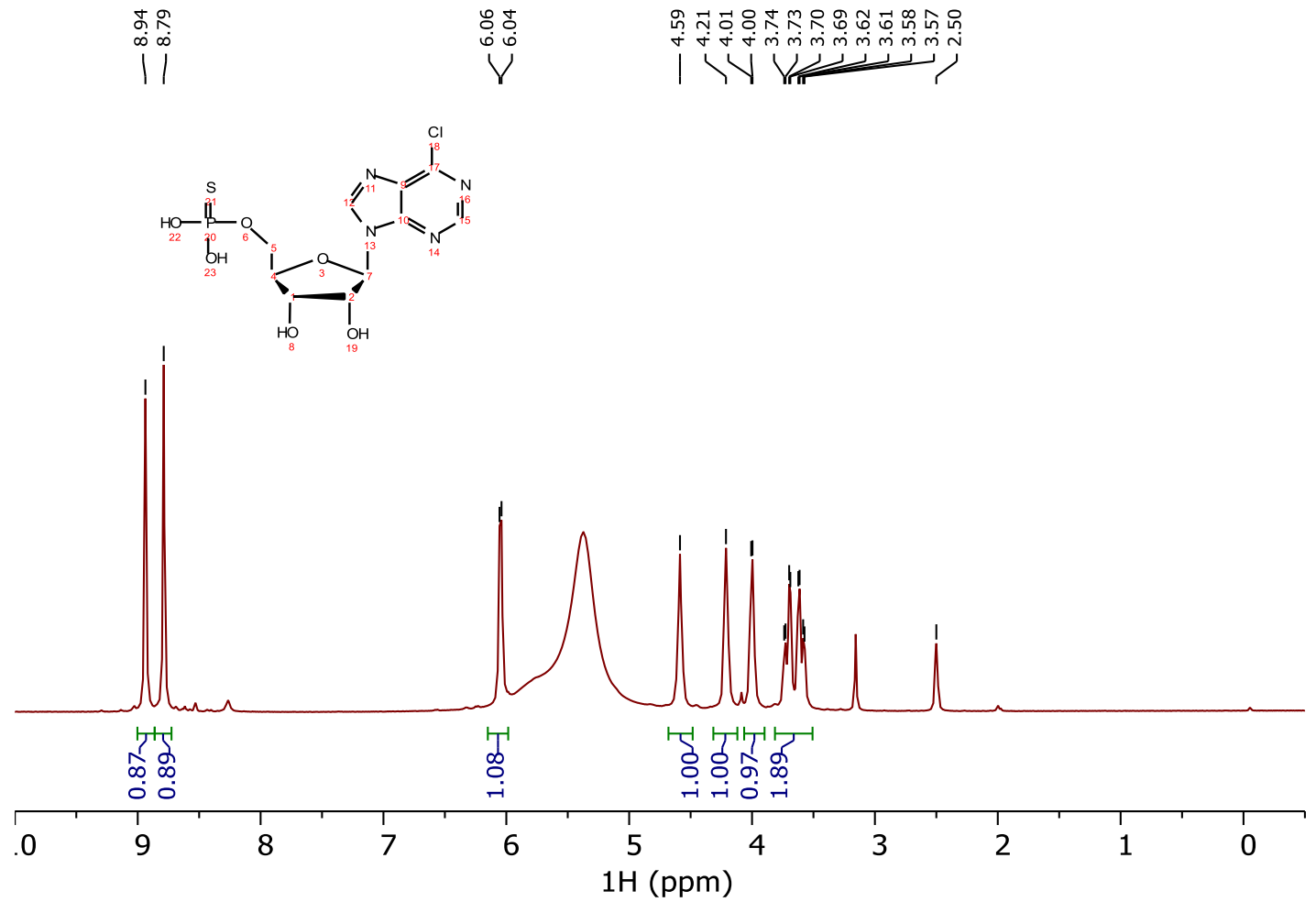

Figure S46. ${ }^{1} \mathrm{H}$ NMR $(300 \mathrm{MHz})$ spectrum of $\mathbf{9 b}$ in $d_{6}$-DMSO.
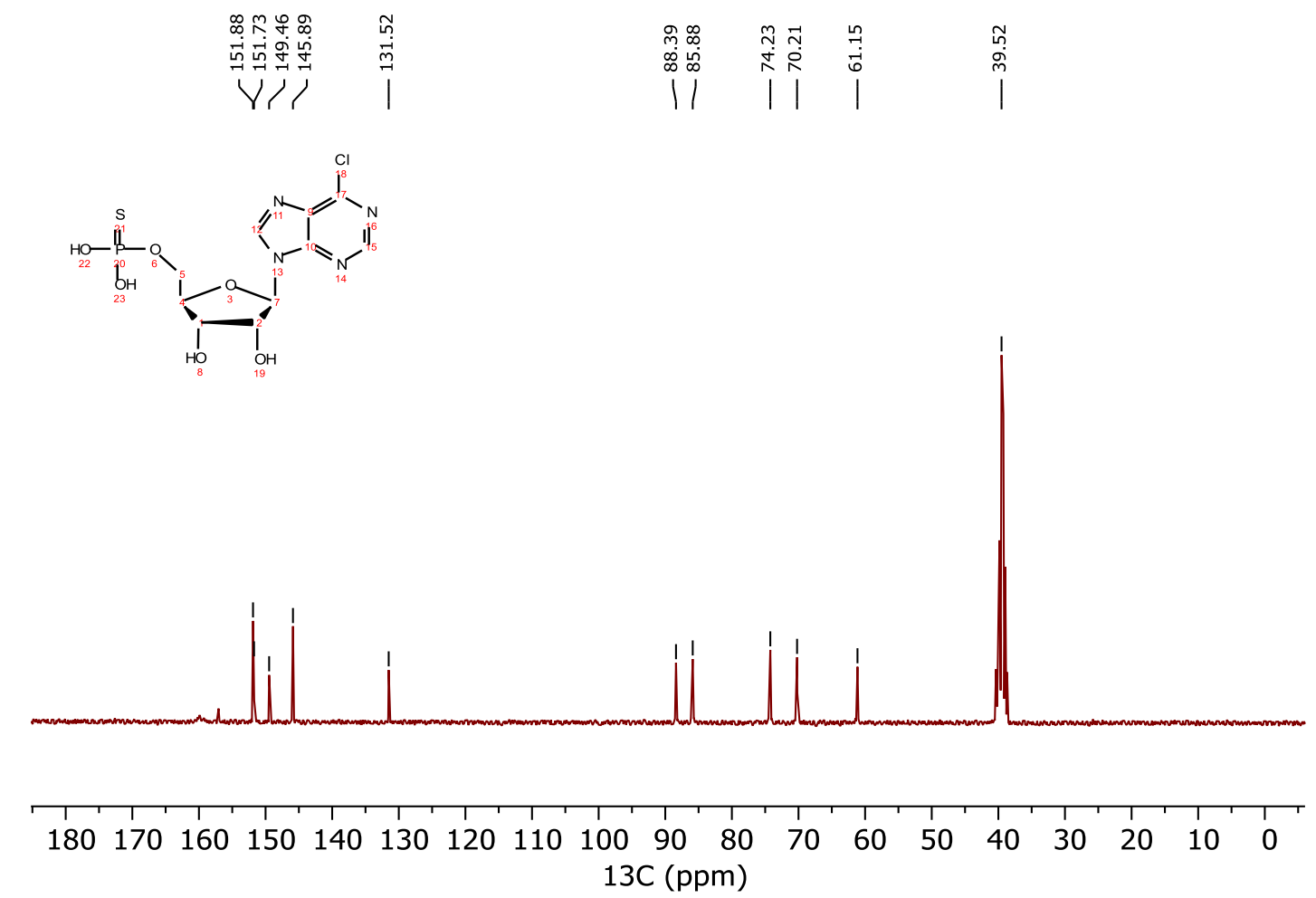

Figure S47. ${ }^{13} \mathrm{C}\left\{{ }^{1} \mathrm{H}\right\}$ NMR (75 MHz) spectrum of $\mathbf{9 b}$ in $d_{6}$-DMSO. 


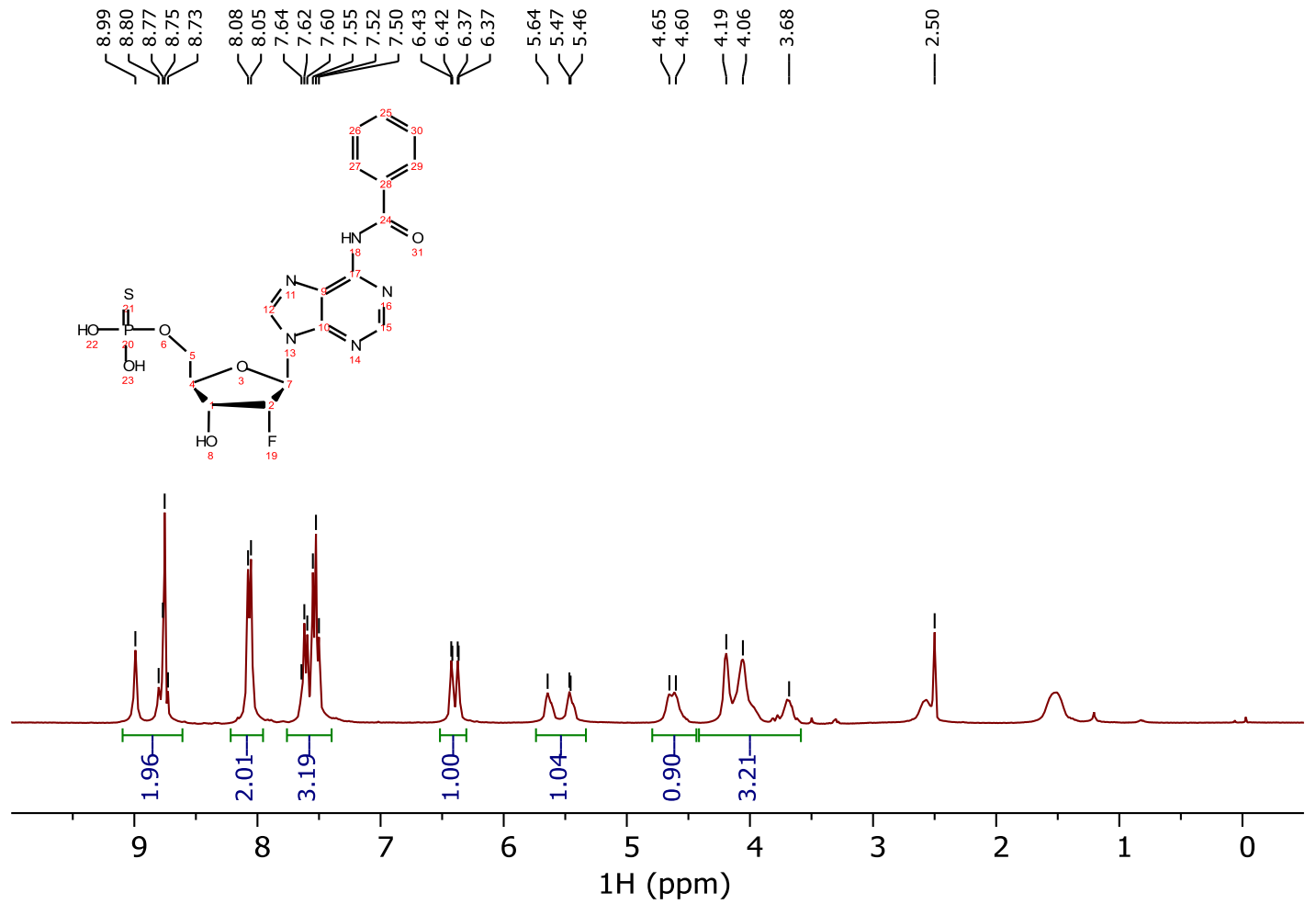

Figure S48. ${ }^{1} \mathrm{H}$ NMR (300 MHz) spectrum of $\mathbf{1 0 b}$ in $d_{6}$-DMSO.

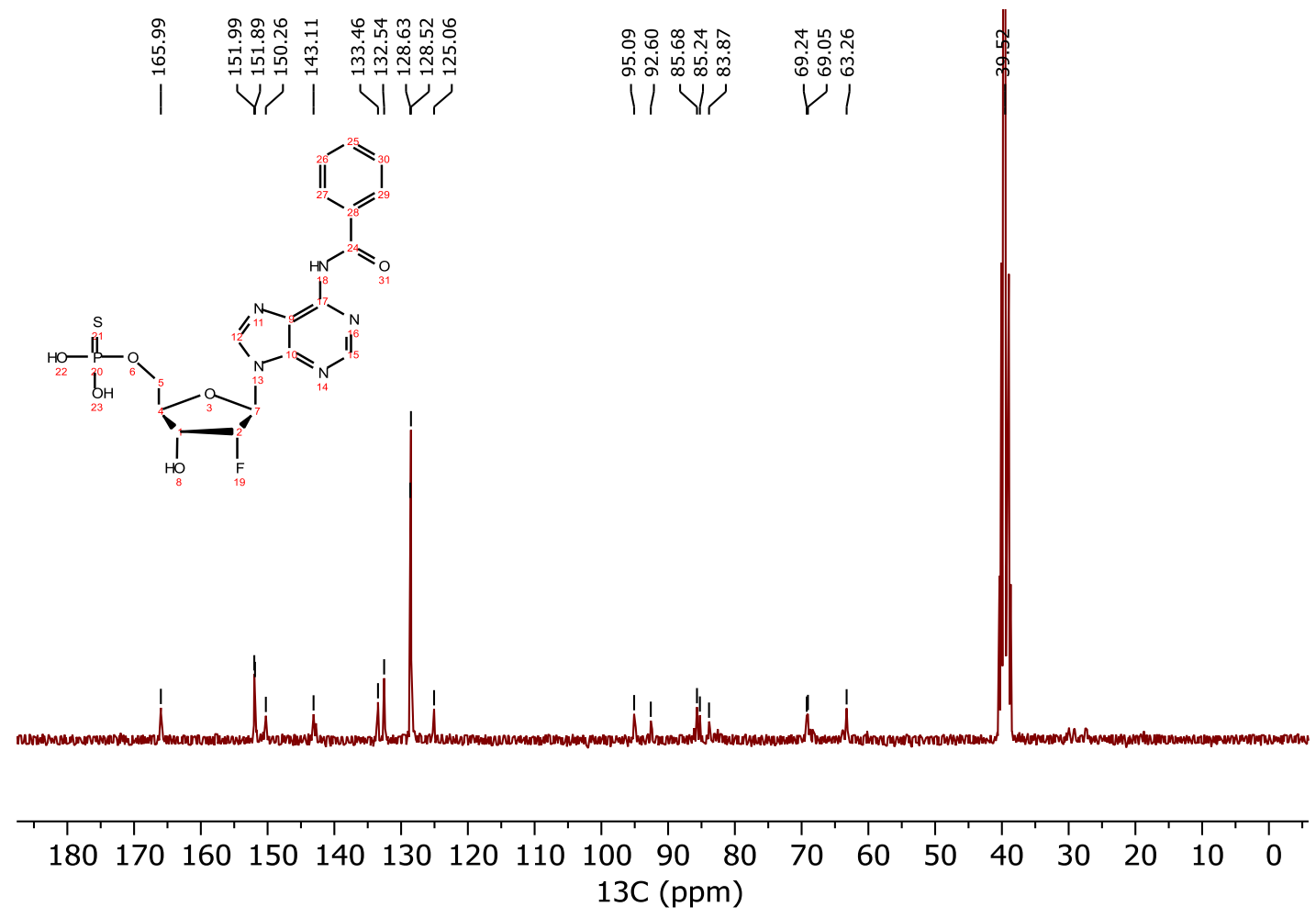

Figure S49. ${ }^{13} \mathrm{C}\left\{{ }^{1} \mathrm{H}\right\}$ NMR $(75 \mathrm{MHz})$ spectrum of $\mathbf{1 0 b}$ in $d_{6}$-DMSO. 


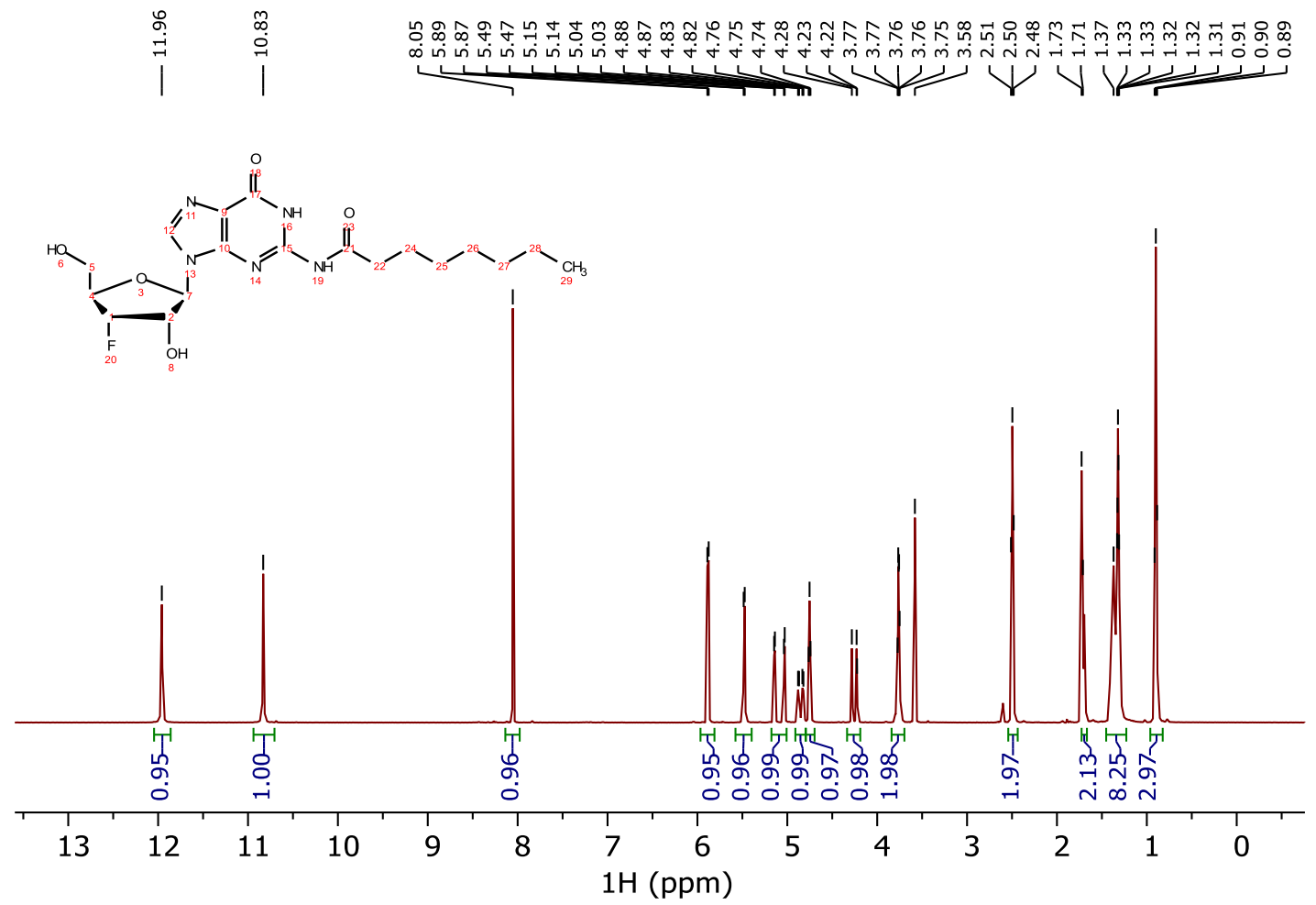

Figure S50. ${ }^{1} \mathrm{H}$ NMR $(300 \mathrm{MHz})$ spectrum of $\mathbf{1 a}$ ' in THF- $d_{8}$.

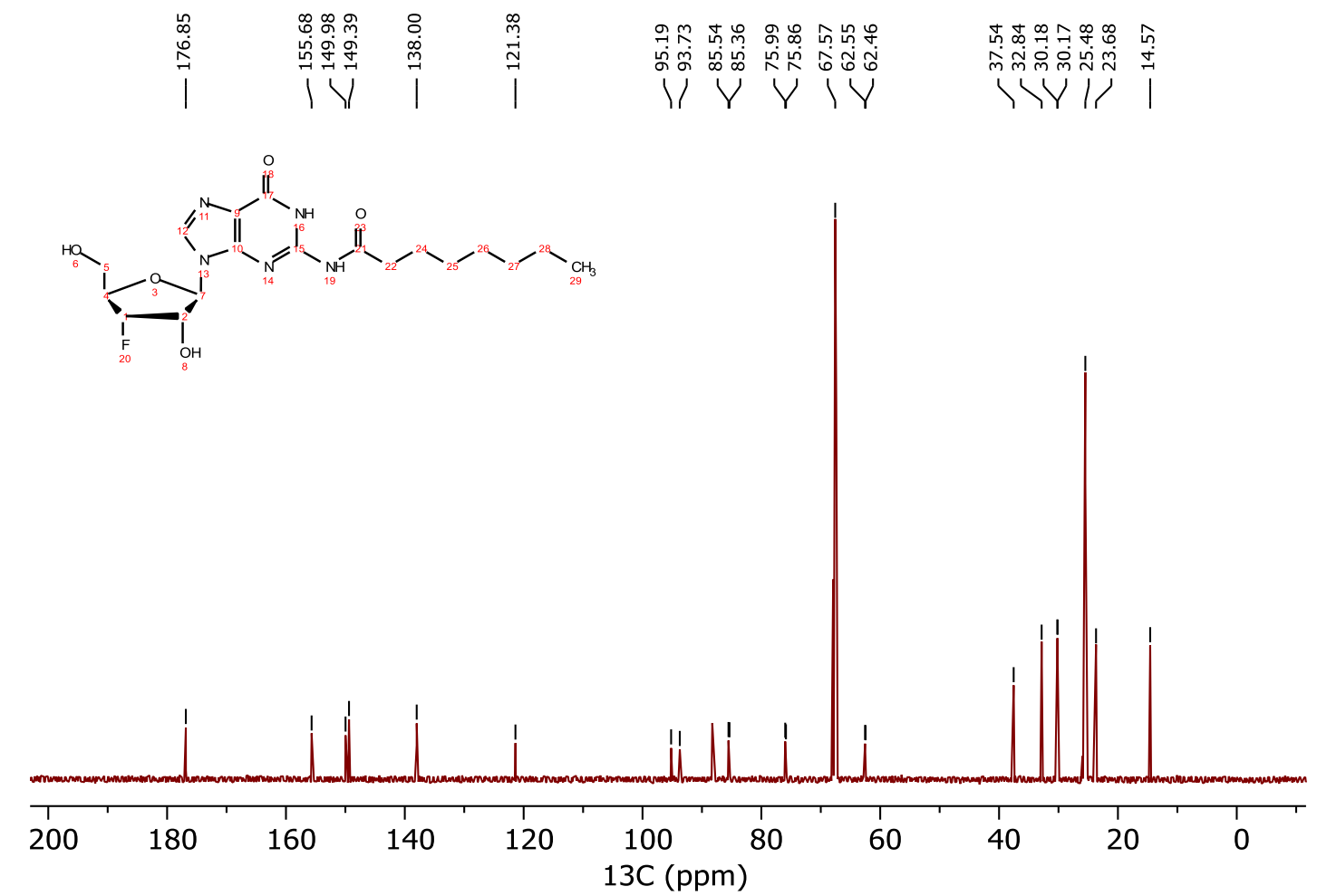

Figure S51. ${ }^{13} \mathrm{C}\left\{{ }^{1} \mathrm{H}\right\}$ NMR (75 MHz) spectrum of 1a' in THF- $d_{8}$. 


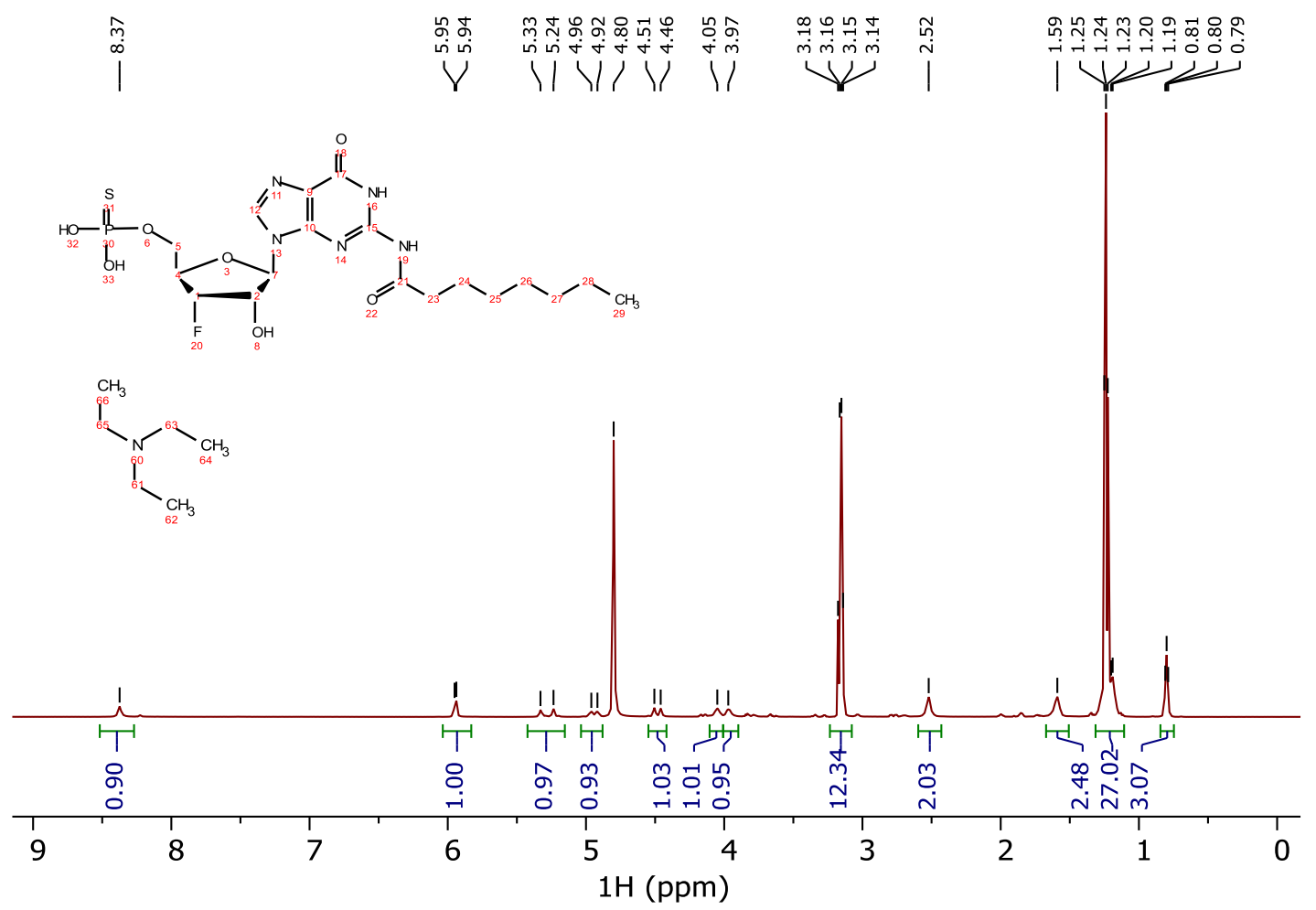

Figure S52. ' $\mathrm{H}$ NMR (600 MHz) spectrum of 1b' in $\mathrm{D}_{2} \mathrm{O}$.
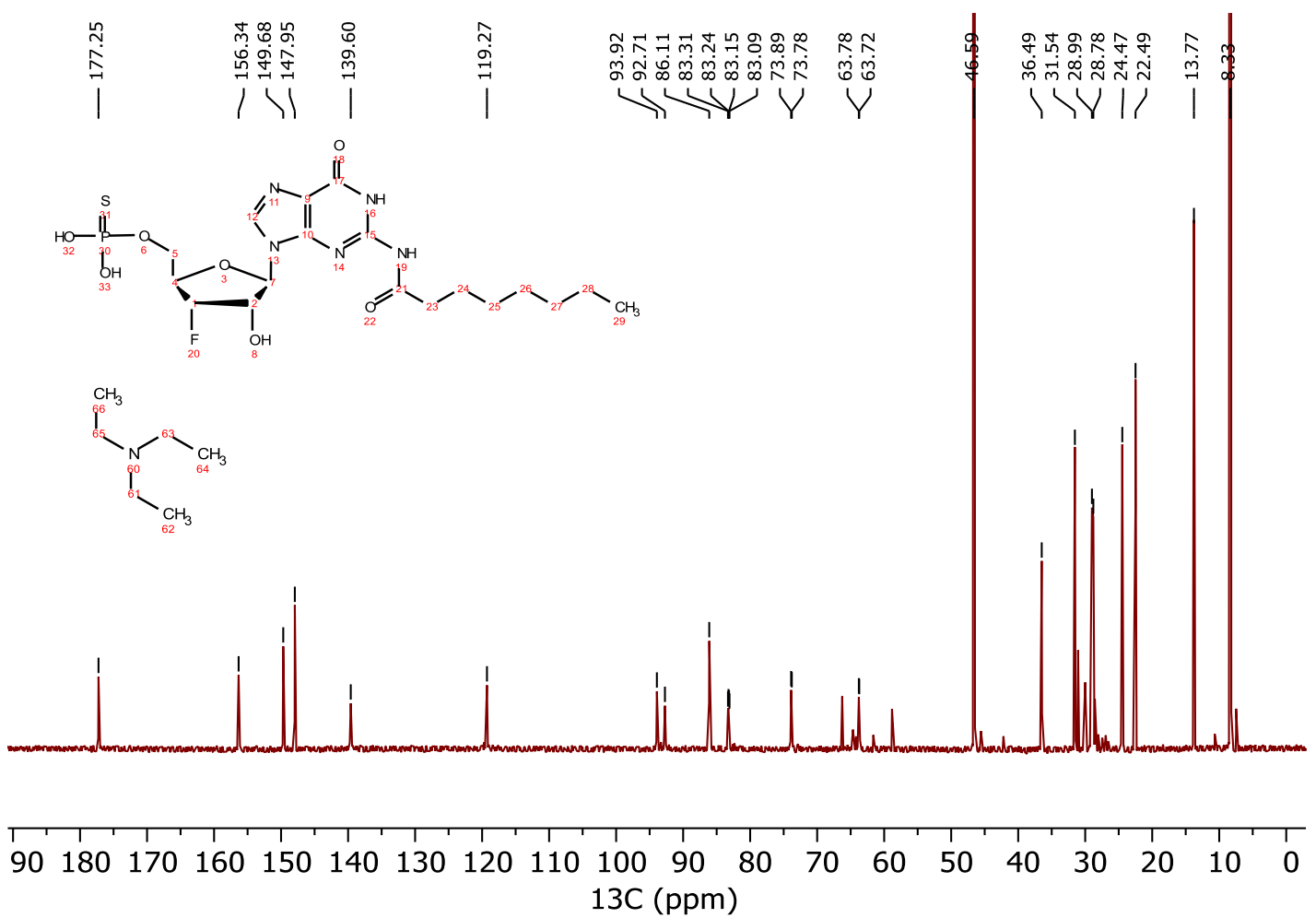

Figure S53. ${ }^{13} \mathrm{C}\left\{{ }^{1} \mathrm{H}\right\}$ NMR $(151 \mathrm{MHz})$ spectrum of $\mathbf{1 b}$ ' in $\mathrm{D}_{2} \mathrm{O}$. 


\section{Characterization of impurities}

O-((2R,3S,4R,5R)-2-(2-amino-6-oxo-1,6-dihydro-9H-purin-9-yl)-4-fluoro-5-

(hydroxymethyl)tetrahydrofuran-3-yl) O,O-dihydrogen phosphorothioate, 1c'

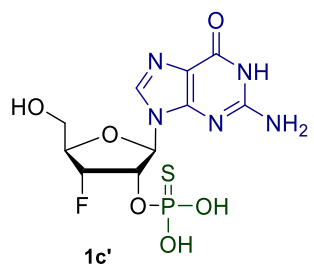

${ }^{1} \mathrm{H}$ NMR $\left(600 \mathrm{MHz}, \mathrm{D}_{2} \mathrm{O}\right): \delta(\mathrm{ppm}) 8.15(\mathrm{~s}, 1 \mathrm{H}), 6.05(\mathrm{~d}, J=7.4 \mathrm{~Hz}, 1 \mathrm{H}), 5.51-5.32(\mathrm{~m}, 2 \mathrm{H}), 4.56(\mathrm{~d}, J$ $=27.1 \mathrm{~Hz}, 1 \mathrm{H}), 4.00-3.80(\mathrm{~m}, 2 \mathrm{H}) .{ }^{13} \mathrm{C}$ NMR (151 MHz, $\mathrm{H}_{2} \mathrm{O} / 10 \%$ DMSO-d $)$ : $\delta$ (ppm) 160.3, 155.4, 153.2, 140.2, 118.2, $93.4(\mathrm{~d}, J=183.2 \mathrm{~Hz}), 87.5(\mathrm{~d}, J=8.0 \mathrm{~Hz}), 85.8(\mathrm{~d}, J=22.6 \mathrm{~Hz}), 75.6(\mathrm{~d}, J=15.5$ $\mathrm{Hz}), 62.8(\mathrm{~d}, J=11.4 \mathrm{~Hz}) .{ }^{31} \mathrm{P} \mathrm{NMR}\left(243 \mathrm{MHz}, \mathrm{D}_{2} \mathrm{O}\right): \delta(\mathrm{ppm}) 45.2$.

O-(((2R,3R,4S,5R)-5-(2-amino-6-oxo-1,6-dihydro-9H-purin-9-yl)-3-fluoro-4-

(thiophosphonooxy)tetrahydrofuran-2-yl)methyl) O,O-dihydrogen phosphorothioate, $1 d^{\prime}$

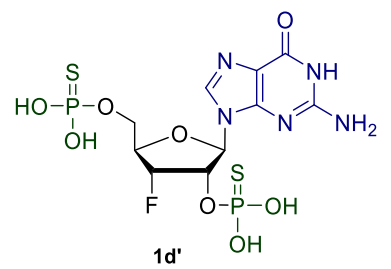

${ }^{1} \mathrm{H}$ NMR (600 MHz, D $\left.2 \mathrm{O}\right): \delta(\mathrm{ppm}) 8.27(\mathrm{~s}, 1 \mathrm{H}), 5.90(\mathrm{~d}, J=8.0 \mathrm{~Hz}, 1 \mathrm{H}), 5.35(\mathrm{dd}, J=53.5,3.9 \mathrm{~Hz}, 1 \mathrm{H})$, 5.18 (dddd, $J=23.9,11.8,8.1,4.2 \mathrm{~Hz}, 1 \mathrm{H}), 4.56(\mathrm{~d}, J=27.3 \mathrm{~Hz}, 1 \mathrm{H}), 4.08-3.90(\mathrm{~m}, 2 \mathrm{H}) .{ }^{13} \mathrm{C}$ NMR $(151$ $\left.\mathrm{MHz}, \mathrm{D}_{2} \mathrm{O}\right): \delta(\mathrm{ppm}) 158.6,153.8,152.0,138.0,115.7,92.3(\mathrm{~d}, J=182.6 \mathrm{~Hz}), 84.5$ (d, $\left.J=7.6 \mathrm{~Hz}\right), 83.0$ $(\mathrm{dd}, J=23.2,9.2 \mathrm{~Hz}), 75.3(\mathrm{~d}, J=13.7 \mathrm{~Hz}), 64.0 .{ }^{19} \mathrm{~F} \mathrm{NMR}\left(564 \mathrm{MHz}, \mathrm{D}_{2} \mathrm{O}\right): \delta(\mathrm{ppm})-195.42(\mathrm{dt}, J=52.9$, $25.8 \mathrm{~Hz}) .{ }^{31} \mathrm{P}$ NMR $\left(243 \mathrm{MHz}, \mathrm{D}_{2} \mathrm{O}\right): \delta(\mathrm{ppm}) 45.6(\mathrm{~d}, \mathrm{~J}=186.5 \mathrm{~Hz})$.

O,O-bis(((2R,3S,4S,5R)-5-(2-amino-6-oxo-1,6-dihydro-9H-purin-9-yl)-3-fluoro-4hydroxytetrahydrofuran-2-yl)methyl) O-hydrogen phosphorothioate, $1 e$

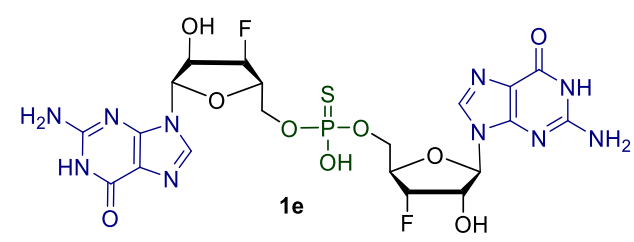

${ }^{1} \mathrm{H}$ NMR (500 MHz, DMSO- $\left.d_{6}\right): \delta(\mathrm{ppm}) 8.33$ (s, 1H), 8.30 (s, 1H), 5.82 (brs, 1H), 5.81 (brs, 1H), 5.33 $4.92(\mathrm{~m}, 4 \mathrm{H}), 4.37(\mathrm{brd}, J=27.6 \mathrm{~Hz}, 2 \mathrm{H}), 4.13-3.80(\mathrm{~m}, 4 \mathrm{H}), 2.89-2.75(\mathrm{~m}, 2 \mathrm{H}), 1.32-0.92(\mathrm{~m}, 12 \mathrm{H}) .{ }^{13} \mathrm{C}$ 
NMR (126 MHz, DMSO- $\left.d_{6}\right): \delta$ (ppm) 180.4, 180.4, 155.0, 154.8, 149.1, 149.1, 148.1, 148.0, 139.1, 138.8, 120.6, 120.4, 93.3 (d, $J=181.6 \mathrm{~Hz}$ ), 93.3 (d, $J=181.8 \mathrm{~Hz}), 86.4,86.1,82.3$ (dd, $J=23.4,8.5 \mathrm{~Hz}), 82.1$ $(\mathrm{dd}, J=23.2,8.6 \mathrm{~Hz}), 71.8(\mathrm{~d}, J=16.0 \mathrm{~Hz}), 71.3(\mathrm{~d}, J=15.8 \mathrm{~Hz}), 64.1(\mathrm{~m}), 63.9(\mathrm{~m}), 34.7,34.7,19.0$, 18.9, 18.8. ${ }^{31} \mathrm{P}$ NMR (243 MHz, DMSO- $\left.d_{6}\right): \delta(\mathrm{ppm}) 54.4$. 


\section{DFT computational studies}

All of the quantum chemical calculations were performed with Gaussian $16 .{ }^{1}$ Geometry optimizations and frequency calculations were performed at the $\omega \mathrm{B} 97 \mathrm{XD} / 6-31 \mathrm{G}(\mathrm{d}, \mathrm{p})$ level of theory. ${ }^{2}$ An "ultrafine" integration grid and a two-electron integral accuracy of $10^{-14}$ (int=(Acc2E $=14$, ultrafine $)$ ) were used. The stationary points were characterized as minima or transition structures by the presence of zero or one negative eigenvalue of the Hessian, respectively. The Gibbs energies were calculated for $298.15 \mathrm{~K}$ and 1 atm using the quasi-harmonic approximation proposed by Cramer and Truhlar, ${ }^{3}$ in which all of the real vibrational frequencies lower than $100 \mathrm{~cm}^{-1}$ were set to $100 \mathrm{~cm}^{-1}$ before the thermal corrections were computed with the usual harmonic oscillator model. The concerted nature of the nucleophilic displacement transition structures (TSs) was confirmed by visualization of the imaginary mode of vibration using AMPAC $10 \mathrm{AGUI}^{4}$ for all TSs. Additionally, an intrinsic reaction coordinate (IRC) analysis performed on TS-1a showed the TS to be connected to the reactant complex (a complex with a full $\mathrm{P}-\mathrm{N}^{+}$bond and no $\mathrm{P}-$ $\mathrm{O}$ bond) in one direction of the reaction coordinate and the product complex in the other direction. The illustrations of the computed geometries were prepared using CYLView. ${ }^{5}$

The conformations of all thiophosphorylation TSs involving either the cinchona alkaloid derivative or the model catalyst 6-methoxy-4-methylquinoline were diversified by molecular mechanics conformational searches. For each system, after importing a DFT-optimized thiophosphorylation TS into Maestro, ${ }^{6}$ the positions of the reactive atoms (the quinoline $\mathrm{N}$, the $\mathrm{PSCl}_{2}$ moiety, the reactive $\mathrm{OH}$ group, and the chloride) were frozen and conformational searches were then performed using Macromodel $^{6}$ (OPLS3e force field, ${ }^{6-}$ ${ }^{8}$ no solvent, mixed torsional/low-mode sampling, 10000 steps maximum using 1000 steps per rotatable bonds, energy window for saving structures $=42.0 \mathrm{~kJ} / \mathrm{mol}$, RMSD cutoff for eliminating redundant conformers $=0.5 \AA$ ). The resulting conformers were then submitted to DFT TS calculations. The geometries were first optimized with the $\mathrm{N}^{+} \ldots \mathrm{P}$, the $\mathrm{P} \ldots \mathrm{O}$ and the $\mathrm{Cl}^{-} \ldots \mathrm{H}$ distances fixed. Subsequently, all distance constraints were lifted, and full transition structure searches were performed.

Good correlations were found between the quinine derivatives' reaction rates with various substituents at the $\mathrm{C} 6$ position of the quinoline ring and the HOMO energies computed either for the same quinine derivatives (Figure S54A, left) or the corresponding 6-substituted quinoline derivatives (Figure S54B, right). This further corroborates the proposed role of the quinoline as the key nucleophilic activator in the reaction mechanism. 

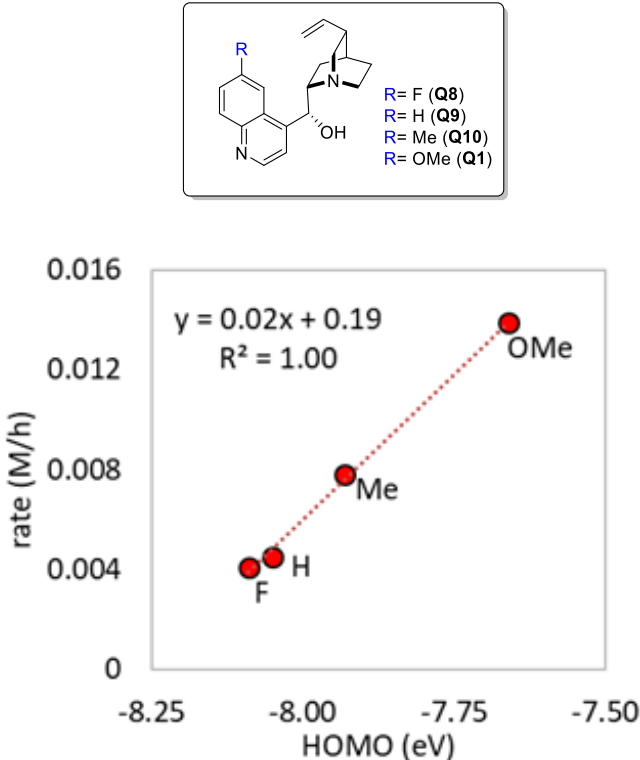
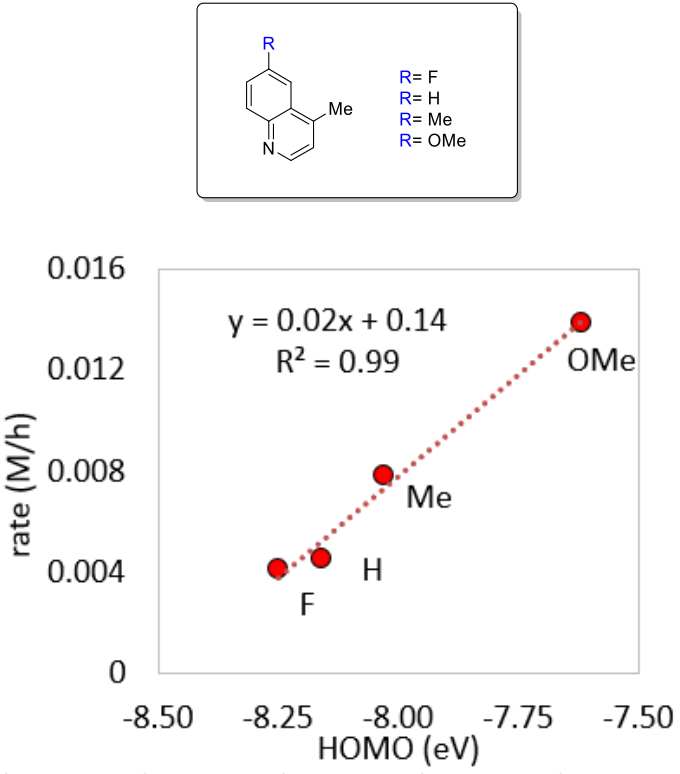

Figure S54. Correlation between DFT (wB97XD/6-31G**)-computed HOMO energies and reaction rates for (A) the different 6-substituted quinine derivatives (B) the various 6-substituted quinoline derivatives.

To explore whether the quinoline nitrogen could function as a general base rather than a nucleophilic catalyst, we used a series of proton-exchange reactions to compute the relative basicities of various substituted model quinolines (Table S14). The DFT calculations indicated an increasing basicity in the order of $\mathrm{R}=\mathrm{Me}>\mathrm{R}=\mathrm{OMe}>\mathrm{R}=\mathrm{H}>\mathrm{R}=\mathrm{F}$. Thus, the quinoline nitrogen atom was predicted to be more basic when $\mathrm{R}=\mathrm{Me}$ than when $\mathrm{R}=\mathrm{OMe}$. However, this is opposite to our experimental observations, as shown in the main text Figure 4c. On the other hand, we observed a clear trend between rates and HOMO energies of the quinolines, as shown in Figure 5. The correlation of the observed reactivity with nucleophilicity rather than basicity is in good agreement with our nucleophilic catalysis proposal.

Table S14. Gibbs energies for proton-exchange equations between I and IIa-c, and differences in basicity of IIa-c relative to I

\begin{tabular}{|c|c|c|c|}
\hline I & \multicolumn{3}{|c|}{} \\
\hline IIa & $\mathrm{Re}$ & $\Delta \mathrm{G}(\mathrm{kcal} / \mathrm{mol})$ & $\Delta \mathrm{pK}_{\mathrm{aH}}{ }^{[\mathrm{a}]}$ \\
\hline IIb & $\mathrm{OMe}$ & 0.61 & 0.44 \\
\hline $\mathbf{I}$ & $\mathrm{H}$ & 0.37 & 0.27 \\
\hline IIc & $\mathrm{F}$ & 0.00 & 0.00 \\
\hline
\end{tabular}

[a] For IIa, IIb and IIc, $\Delta \mathrm{pK}_{\mathrm{aH}}=\mathrm{pK}_{\mathrm{aH}}(\mathbf{I I a}-\mathbf{c})-\mathrm{pK}_{\mathrm{aH}}(\mathbf{I})$ 
ACD labs provided similar trend of basicity in the order of $\mathrm{R}=\mathrm{Me}>\mathrm{R}=\mathrm{H}>\mathrm{R}=\mathrm{OMe}>\mathrm{R}=\mathrm{F}$. Again, the quinoline nitrogen atom was calculated to be more basic when $\mathrm{R}=\mathrm{Me}$ than when $\mathrm{R}=\mathrm{OMe}$.

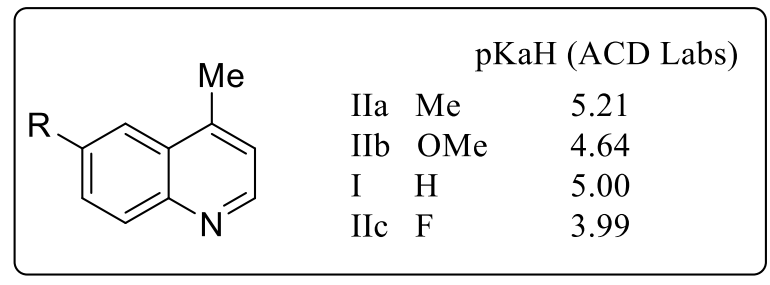

Figure S55. pKa values from ACD labs for I and Ia-c.

The transition structures TS-1a and TS-1b (Figure S63) calculated for the acetyl-protected analog 1a" were repeated for the $n$-octanoyl analog 1a' used in the kinetic studies (Figure S56). The energy difference of $12.4 \mathrm{kcal} / \mathrm{mol}$ in favor of reaction at $\mathrm{C}^{5}$ '-OH is congruent with the large energy difference observed with the acetyl analog 1a". In the optimized transition structures for 1a' or 1a", the methyl group or the $n$-heptyl chain points towards empty space, suggesting that the choice of protecting group should have minimal influence on the computed geometries and relative energies of the transition states.

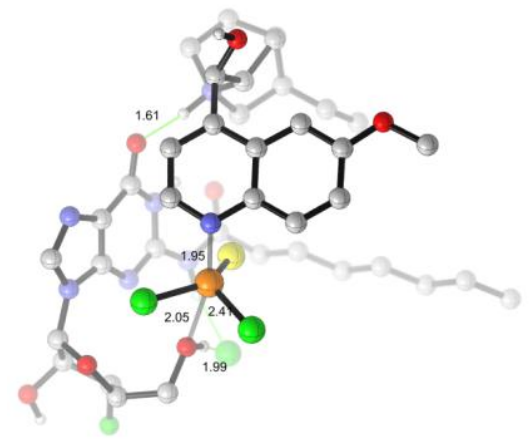

TS-a': $\Delta \mathrm{G}^{*}$ rel $=0 \mathrm{kcal} / \mathrm{mol}$

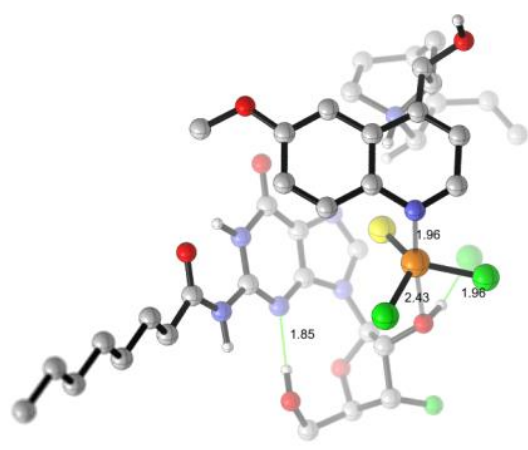

TS-b': $\Delta \mathrm{G}_{\text {rel }}^{\ddagger}=12.4 \mathrm{kcal} / \mathrm{mol}$

Figure S56. DFT $\left(\omega \mathrm{B} 97 \mathrm{XD} / 6-31 \mathrm{G}^{* *}\right)$-computed transition structures for the reaction of C5'-OH (TS-a') and $\mathrm{C}^{\prime}-\mathrm{OH}$ (TS-b') of 1a' with $\mathrm{PSCl}_{3}$ activated by quinine. The non-critical hydrogen atoms are omitted for clarity.

The regioisomeric transition structures for the thiophosphorylation catalyzed by quinine were also computed for substrates 5a and 9a. For 5a (Figure S57), thiophosphorylation at C5'-OH has a barrier at least $10.2 \mathrm{kcal} / \mathrm{mol}$ lower than at C2'-OH or C3'-OH. For 9a (Fig. S58), reaction at C5'-OH is also favored by at least $9.1 \mathrm{kcal} / \mathrm{mol}$. 


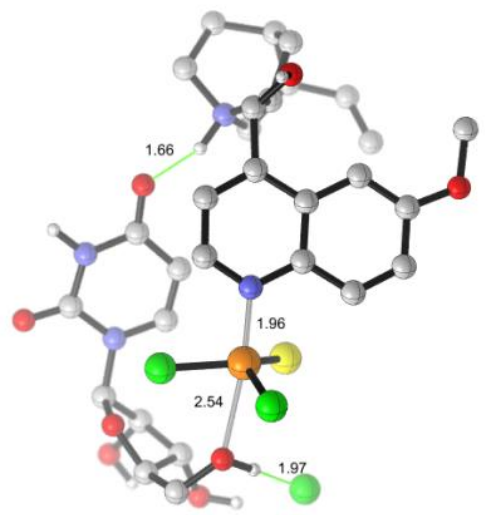

TS-a"

Reaction at $\mathrm{C}^{\prime}-\mathrm{OH}$

$\Delta \mathrm{G}_{\text {rel }}^{\ddagger}=0 \mathrm{kcal} / \mathrm{mol}$

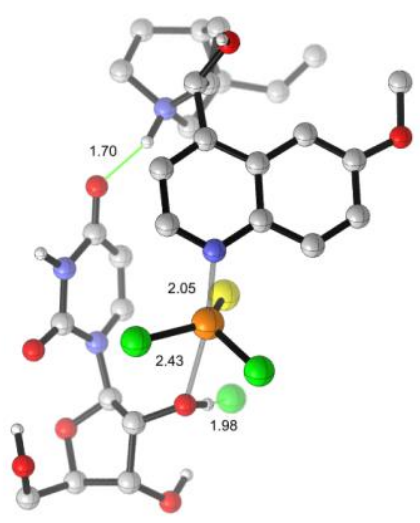

TS-b"

Reaction at $\mathrm{C}^{\prime}-\mathrm{OH}$

$\Delta \mathrm{G}_{\text {rel }}^{\ddagger}=10.2 \mathrm{kcal} / \mathrm{mol}$

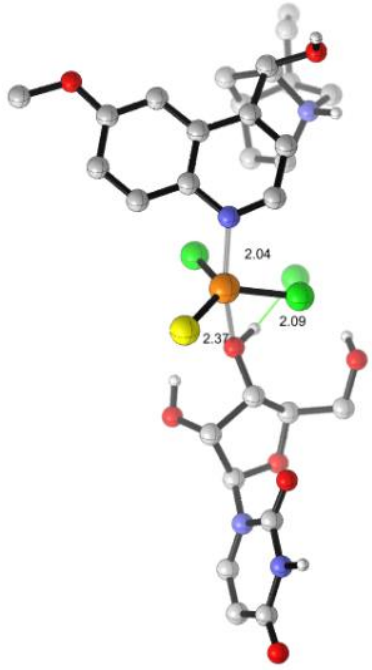

TS-c"

Reaction at C3'-OH

$\Delta \mathrm{G}^{\dagger}{ }_{\text {rel }}=15.9 \mathrm{kcal} / \mathrm{mol}$

Figure S57. DFT ( $\left.\omega \mathrm{B} 97 \mathrm{XD} / 6-31 \mathrm{G}^{* *}\right)$-computed regioisomeric transition structures for the thiophosphorylation of $\mathbf{5 a}$ catalyzed by quinine. The non-critical hydrogen atoms are omitted for clarity.

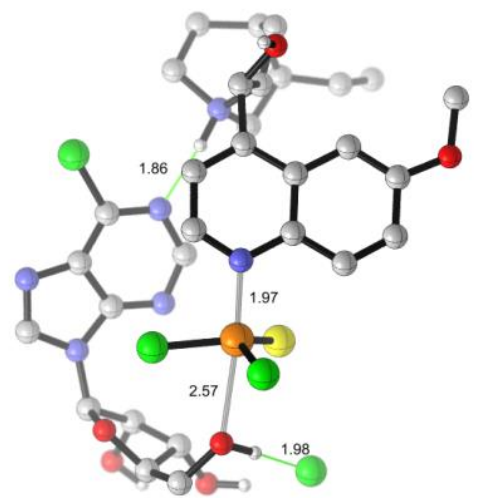

TS-2a

Reaction at $\mathrm{C}^{\prime}$ '-OH

$\Delta \mathrm{G}^{\ddagger}$ rel $=0 \mathrm{kcal} / \mathrm{mol}$

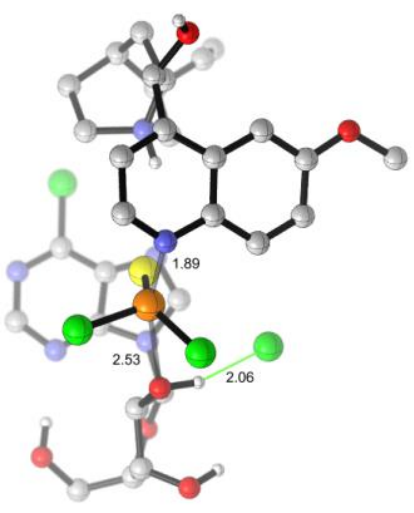

TS-2b

Reaction at $\mathrm{C}^{\prime}-\mathrm{OH}$

$\Delta \mathrm{G}^{\sharp}$ rel $=9.1 \mathrm{kcal} / \mathrm{mol}$

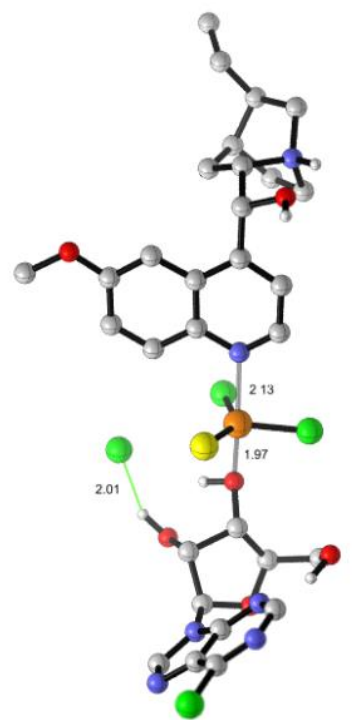

TS-2c

Reaction at $\mathrm{C} 3{ }^{\prime}-\mathrm{OH}$

$\Delta \mathrm{G}^{\ddagger}$ rel $=11.6 \mathrm{kcal} / \mathrm{mol}$

Figure S58. DFT $\left(\omega \mathrm{B} 97 \mathrm{XD} / 6-31 \mathrm{G}^{* *}\right)$-computed regioisomeric transition structures for the thiophosphorylation of 9 a catalyzed by quinine. The non-critical hydrogen atoms are omitted for clarity.

The regioisomeric TSs for the Q2-catalyzed thiophosphorylation of 1a" were also explored (Figure S59). The C5'-OH (TS-3a) was thiophosphorylated preferentially over C2'-OH (TS-3b) by a difference in barrier of $16.5 \mathrm{kcal} / \mathrm{mol}$. In TS-3a, the guanosine C6 carbonyl oxygen is engaged in non-classical hydrogen bonds with three $\mathrm{C}-\mathrm{H}$ groups adjacent to the quaternary ammonium $\mathrm{N}+$. By contrast, thiophosphorylation at $\mathrm{C} 2$ '- 
$\mathrm{OH}$ group is substantially less compatible with the cinchona alkaloid scaffold and displays a significantly twisted geometry at the phosphorus site as the guanosine C6 carbonyl oxy-gen maintains only two ammonium $\mathrm{N}+\mathrm{C}(\mathrm{sp} 3)-\mathrm{H} . . . \mathrm{O}$ interactions.

The 3- to 4-fold rate enhancement observed with the N-benzyl derivative $\mathbf{Q 2}$ is equivalent to a reduction in activation barrier by about $0.8 \mathrm{kcal} / \mathrm{mol}$ compared to quinine. This energy differential is highly challenging to capture by currently available quantum chemical computational methods, not least because of the large molecular size, high conformational flexibility, and the involvement of ion pairs, which brings further complications in ensuring exhaustive configurational sampling. Thus, detailed computational elucidation of the structural origin of the rate enhancement in the catalysis by $\mathbf{Q} 2$ relative to catalysis by quinine is considered to be out of the scope of this study.

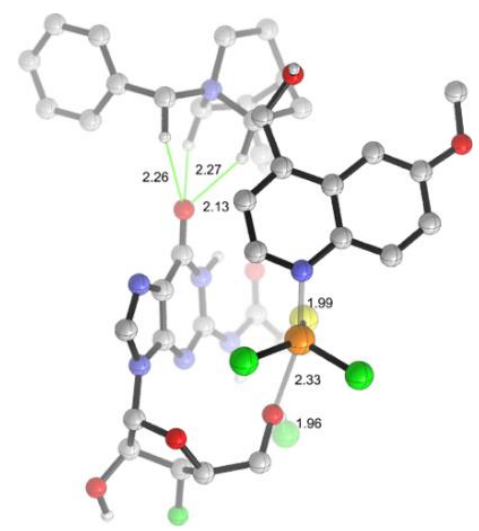

TS-3a

Reaction at $\mathrm{C}^{\prime}-\mathrm{OH}$ $\Delta \mathrm{G}_{\mathrm{rel}}^{\ddagger}=0 \mathrm{kcal} / \mathrm{mol}$

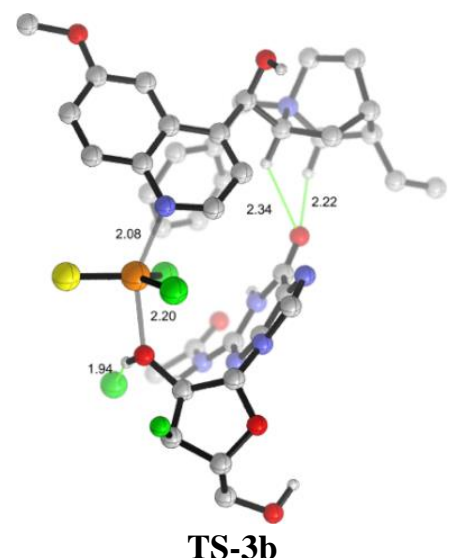

Reaction at $\mathrm{C}^{\prime}-\mathrm{OH}$ $\Delta \mathrm{G}_{\mathrm{rel}}^{\ddagger}=16.5 \mathrm{kcal} / \mathrm{mol}$

Figure S59. DFT $\left(\omega \mathrm{B} 97 \mathrm{XD} / 6-31 \mathrm{G}^{* *}\right)$-computed regioisomeric transition structures for the thiophosphorylation of 19" at C5'-OH (TS-3a) and C2'-OH (TS-3b) activated by Q2. The non-critical hydrogen atoms are omitted for clarity.

We furthermore explored the use of 6-methoxy-4-methylquinoline as a model catalyst devoid of the chiral pocket. The energy differences between the regioisomeric TSs are significantly diminished for all three substrates modeled. For 1a" (TS-4a-b, Figure S60), reaction at C5'-OH was found to be favored only by $4.6 \mathrm{kcal} / \mathrm{mol}$. For 5a (TS-5a-c, Figure S61) and 9a (TS-6a-c, Figure S62), the energy differences are smaller than $0.8 \mathrm{kcal} / \mathrm{mol}$ favoring a hydroxyl group other than the $\mathrm{C}^{2}$ '-OH that was experimentally found to react selectively. 


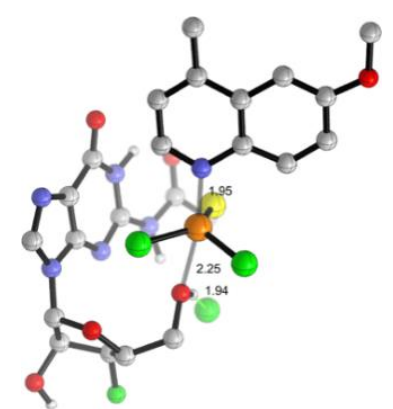

TS-4a

Reaction at $\mathrm{C}^{\prime}-\mathrm{OH}$ $\Delta \mathrm{G}^{\ddagger} \mathrm{rel}=0 \mathrm{kcal} / \mathrm{mol}$

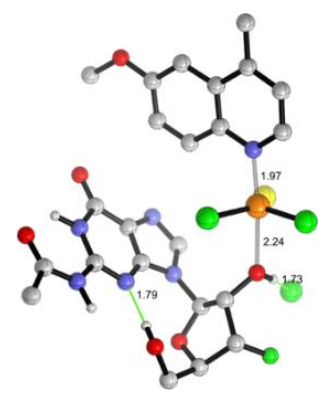

TS-4b

Reaction at $\mathrm{C} 2$ '-OH

$\Delta \mathrm{G}^{\ddagger}$ rel $=4.6 \mathrm{kcal} / \mathrm{mol}$

Figure S60. DFT $\left(\omega \mathrm{B} 97 \mathrm{XD} / 6-31 \mathrm{G}^{* *}\right)$-computed regioisomeric transition structures for the thiophosphorylation of 1a" catalyzed by model catalyst 6-methoxy-4-methylquinoline. The non-critical hydrogen atoms are omitted for clarity.

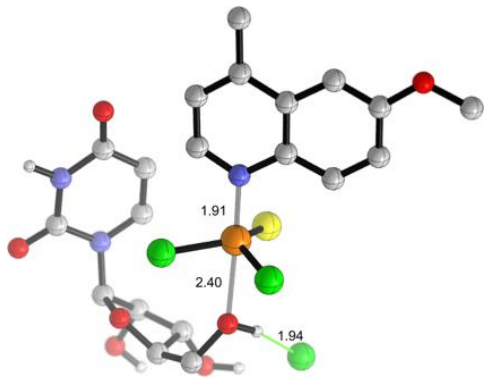

TS-5a

Reaction at $\mathrm{C}^{\prime}-\mathrm{OH}$ $\Delta \mathrm{G}_{\text {rel }}^{\ddagger}=0.8 \mathrm{kcal} / \mathrm{mol}$

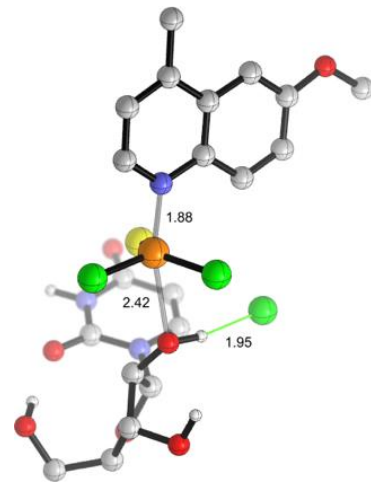

TS-5b

Reaction at $\mathrm{C} 2$ '- $\mathrm{OH}$ $\Delta \mathrm{G}_{\mathrm{rel}}^{\dagger}=0 \mathrm{kcal} / \mathrm{mol}$

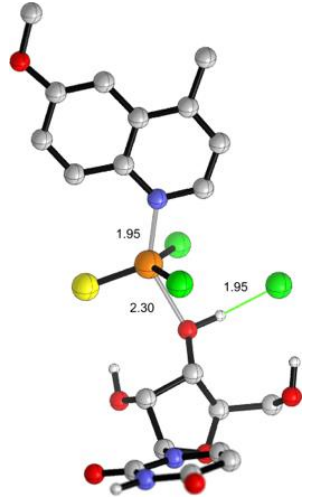

TS-5c

Reaction at $\mathrm{C}$ ' $-\mathrm{OH}$ $\Delta \mathrm{G}_{\mathrm{rel}}^{\ddagger}=3.7 \mathrm{kcal} / \mathrm{mol}$

Figure S61. DFT $\left(\omega \mathrm{B} 97 \mathrm{XD} / 6-31 \mathrm{G}^{* *}\right)$-computed regioisomeric transition structures for the thiophosphorylation of $\mathbf{5 a}$ catalyzed by model catalyst 6-methoxy-4-methylquinoline. The non-critical hydrogen atoms are omitted for clarity. 


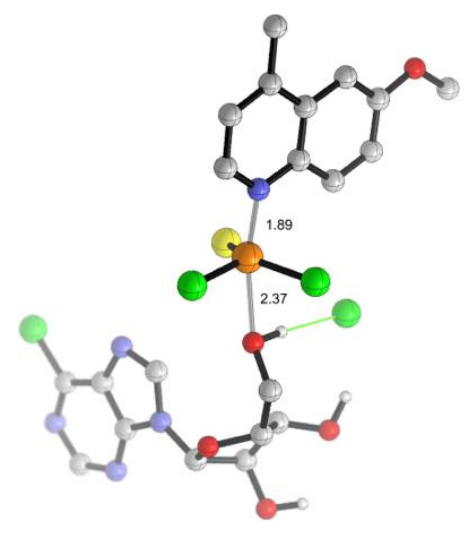

TS-6a

Reaction at $\mathrm{C}^{\prime}-\mathrm{OH}$ $\Delta \mathrm{G}^{\dagger}$ rel $=1.6 \mathrm{kcal} / \mathrm{mol}$

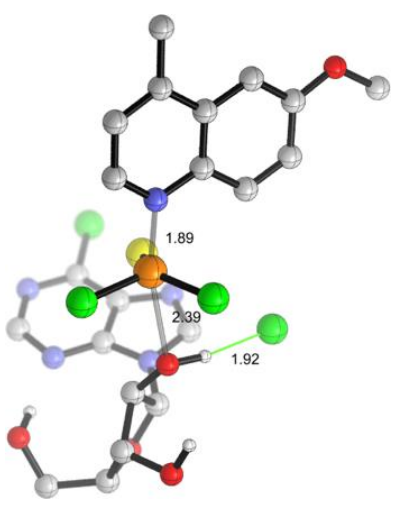

TS-6b

Reaction at $\mathrm{C}^{\prime}$ '-OH $\Delta \mathrm{G}^{\ddagger}$ rel $=0 \mathrm{kcal} / \mathrm{mol}$

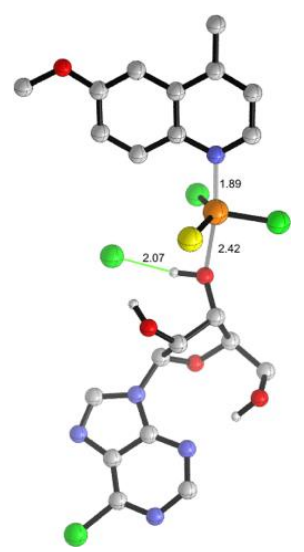

TS-6c

Reaction at $\mathrm{C}^{2}$ '-OH $\Delta \mathrm{G}_{\text {rel }}^{\ddagger}=0.5 \mathrm{kcal} / \mathrm{mol}$

Figure S62. DFT ( $\left.\omega \mathrm{B} 97 \mathrm{XD} / 6-31 \mathrm{G}^{* *}\right)$-computed regioisomeric transition structures for the thiophosphorylation of 9a catalyzed by model catalyst 6-methoxy-4-methylquinoline. The non-critical hydrogen atoms are omitted for clarity.

Figure S63 shows the transition state structures for quinine-catalyzed thiophosphorylation of 1a". TS-b is $13.1 \mathrm{kcal} / \mathrm{mol}$ higher in energy than TS-a, agreeing with the exclusive C5'-OH selectivity experimentally observed. In TS-a, the protonated quinuclidine donates a hydrogen bond to guanosine ring carbonyl oxygen. In contrast, the guanosine $\mathrm{C} 2-\mathrm{NH}$ hydrogen bonds with the chloride anion, which serves for activation of the nucleoside via deprotonation of the primary hydroxyl group as the $\mathrm{O}-\mathrm{P}$ bond is formed. The geometry of TS-a is also consistent with the structure-reactivity correlations with quinine derivatives.

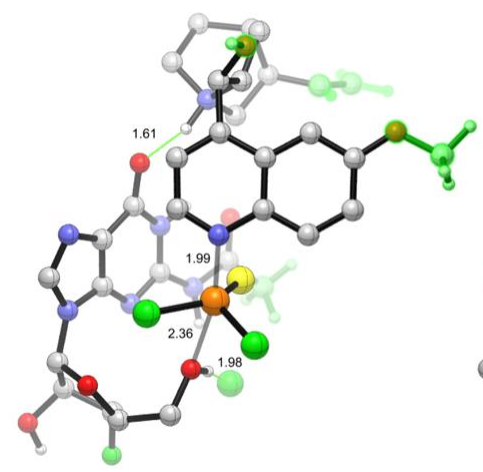

TS-1a

Reaction at $\mathrm{C}^{\prime}$ '-OH $\Delta \mathrm{G}_{\text {rel }}^{\ddagger}=0 \mathrm{kcal} / \mathrm{mol}$

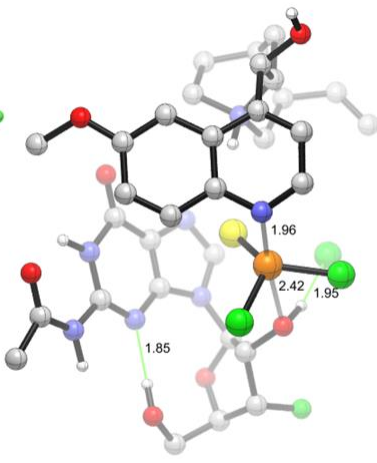

TS-1b

Reaction at $\mathrm{C}^{\prime}$ '-OH

$\Delta \mathrm{G}^{*}{ }_{\mathrm{rel}}=13.1 \mathrm{kcal} / \mathrm{mol}$

Figure S63. DFT (wB97XD/6-31G**)-computed transition structures for the reactions of C5'-OH (TS-1a) and $\mathrm{C}^{\prime}-\mathrm{OH}$ (TS-1b) of 1a" with $\mathrm{PSCl}_{3}$ activated by quinine. In TS-a, the hydroxyl, methoxy, and vinyl 
groups of quinine and the methyl group of 1a" are highlighted. The non-critical hydrogen atoms are omitted for clarity.

\subsection{Intrinsic reaction coordinate}

Intrinsic reaction coordinate (IRC) calculations were performed by following the path in Cartesian coordinates without mass weighting. The Hessian-based Predictor-Corrector (HPC) algorithm and the default step size along the reaction path of 0.1 bohr were used. The Hessian was analytically recomputed every six predictor steps. The forward and the reverse directions were followed in separate computational jobs. The maximum number of points along the reaction path to be examined was set to be 333 . The keywords used in setting up the calculation of the forward IRC path in Gaussian 16 are given as follows: IRC $=($ HPC,Cartesian,calcfc,forward,maxpoint=333, recalc=6). For TS-1a, an energy minimum was detected at point 104 on the reactant side of the pathway and at point 92 on the product side of the pathway.

The IRC path in Fig. S64-A shows TS-1a to be connected to a reactant complex (Figure S64-C) with a full $\mathrm{P}-\mathrm{N}$ bond and a product complex (Figure S64-C) with a full $\mathrm{P}-\mathrm{O}$ bond. No intervening minima were detected, verifying the concerted nature of the nucleophilic substitution at phosphorus. Figure S64-B traces the evolution of bond distances along the IRC path. The formation of the P...O bond (yellow) is accompanied by the cleavage of the $\mathrm{P} \ldots \mathrm{N}^{+}$bond (gray). The $\mathrm{O} \ldots \mathrm{H}$ bond (blue) is also broken as the $\mathrm{H}$...Cl bond (green) is formed. These changes in bond distance support our proposal that $\mathrm{P}$... $\mathrm{O}$ bond formation is accompanied by proton abstraction by the chloride ion in the same mechanistic step.

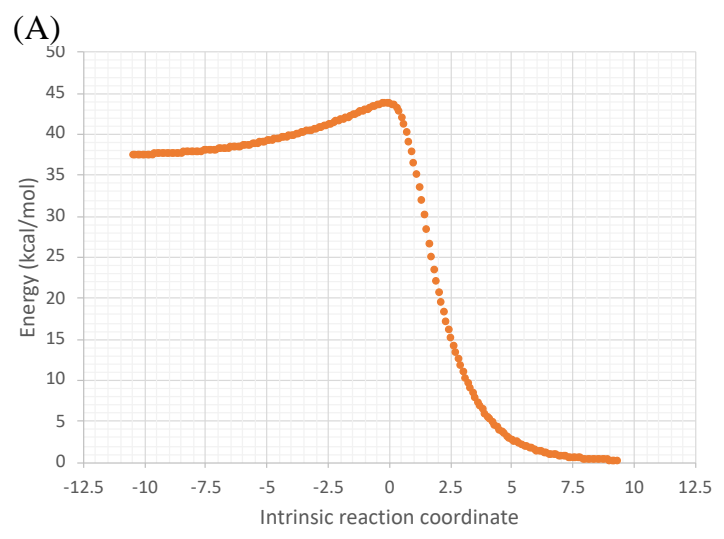

(B)

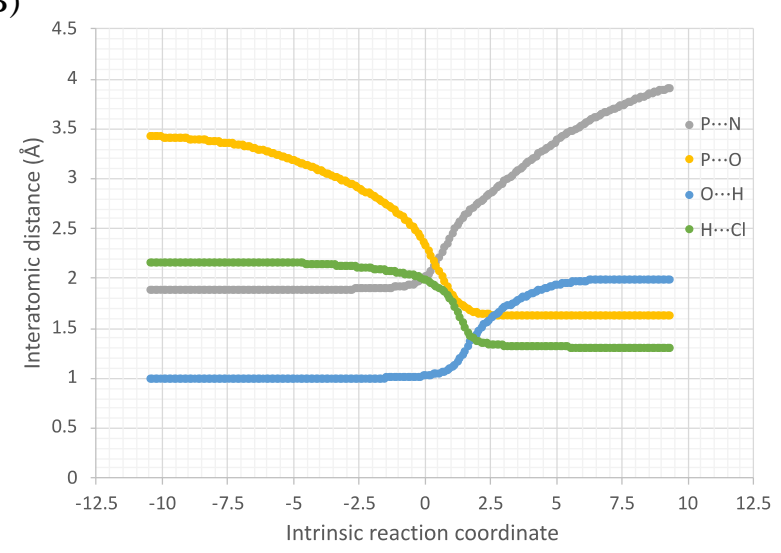


(C)

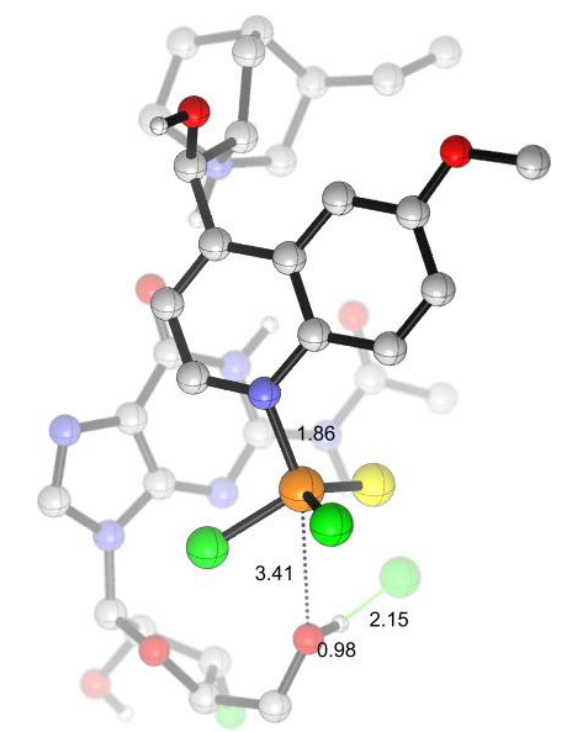

Complex at reactant end of reaction path $(\mathrm{IRC}=-10.4)$

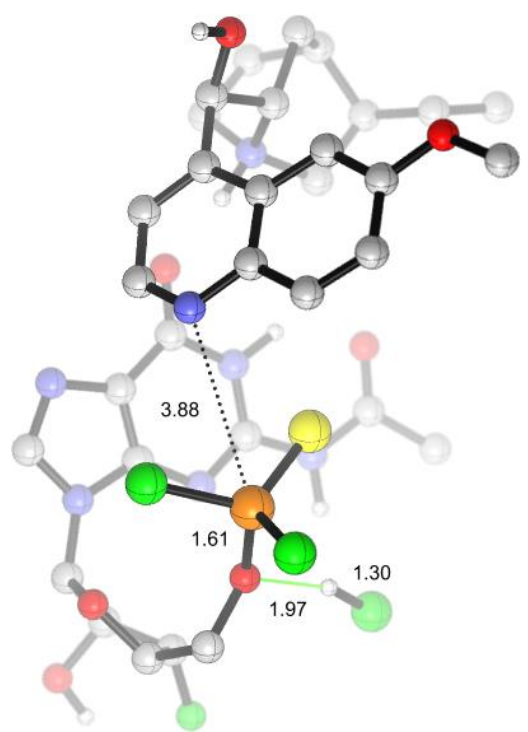

Complex at product end of reaction path $(\mathrm{IRC}=9.4)$

Figure S64. IRC calculations for TS-1a. (A) Energy along the IRC. (B) Evolution of key bond distances pertinent to the reactive moiety along the IRC. (C) Structures of the reactant complex and product complex at the termini of the reaction path. The noncritical hydrogens are omitted for clarity. 


\subsection{Cartesian coordinates of DFT optimized structures}

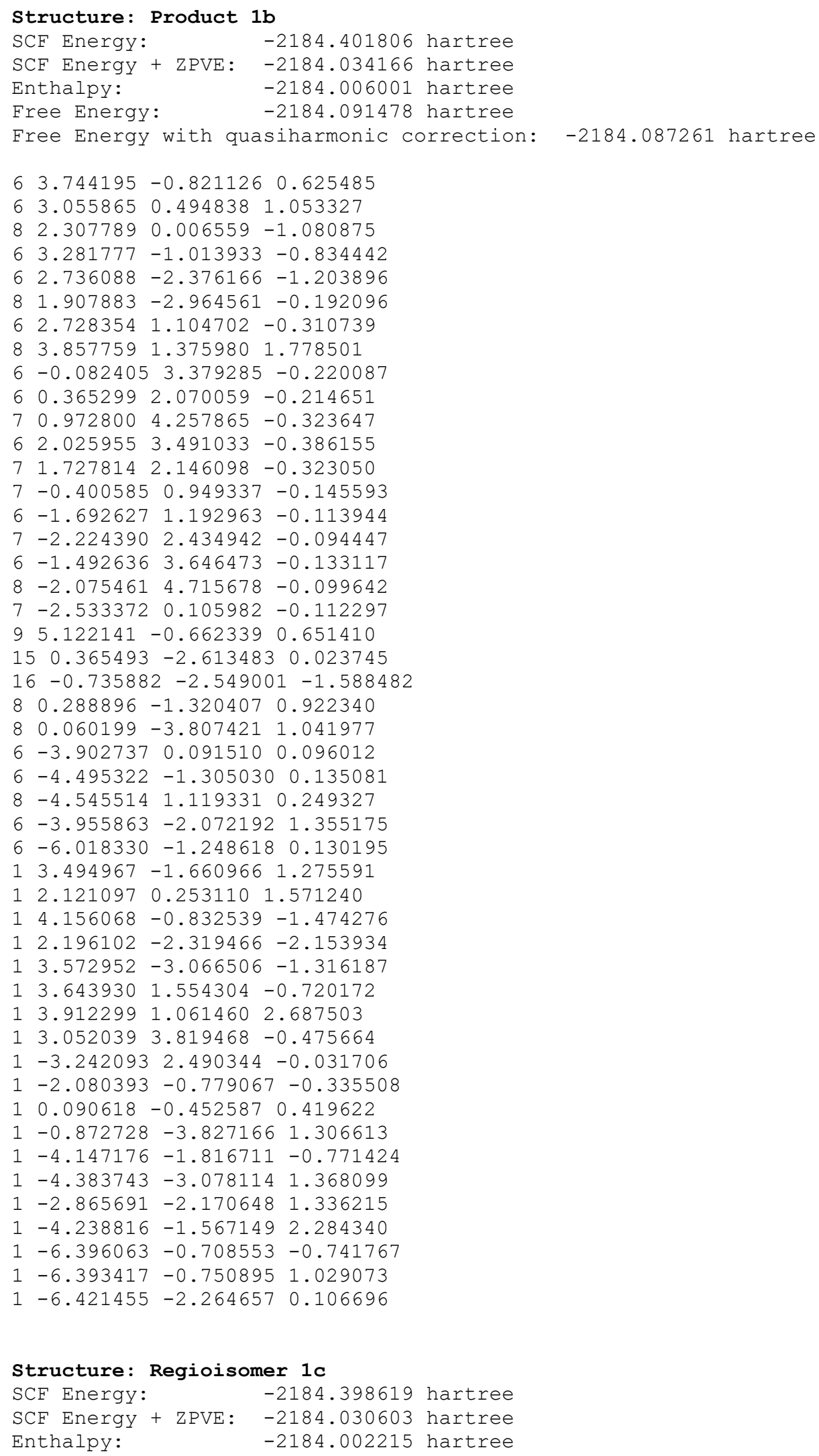




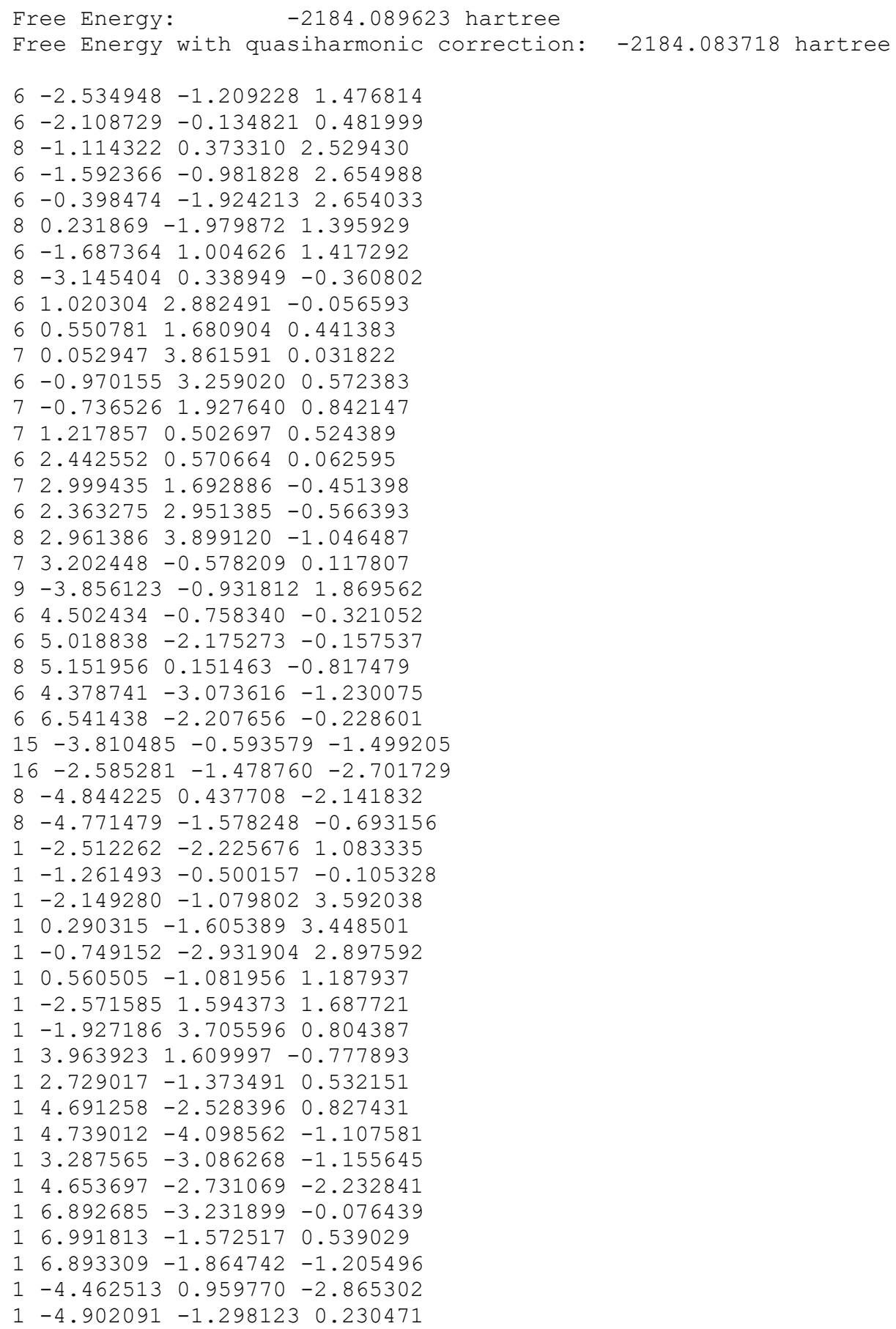

\author{
Structure: Reactant complex in Scheme $\mathrm{S3}$ \\ SCF Energy: $\quad-2368.341525$ hartree \\ SCF Energy + ZPVE: -2368.243341 hartree \\ Enthalpy: $\quad-2368.229764$ hartree \\ Free Energy: $\quad-2368.286750$ hartree \\ Free Energy with quasiharmonic correction: -2368.282842 hartree \\ $\begin{array}{llll}15 & 1.493142 & 0.161092 & -0.003587\end{array}$ \\ $\begin{array}{llll}16 & 1.398648 & 1.985332 & 0.543429\end{array}$ \\ $17 \quad 0.183118-0.415560-1.439647$
}




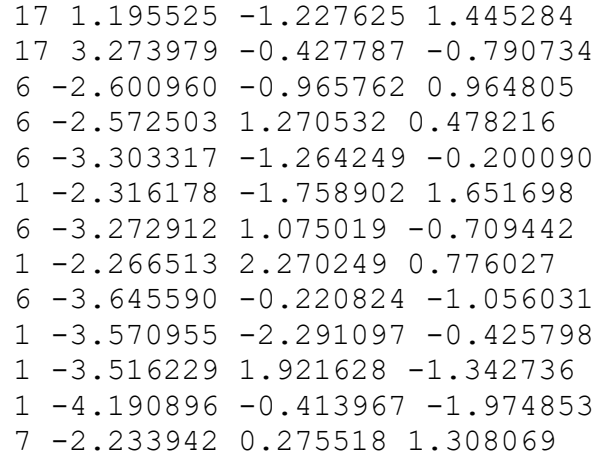

\section{Structure: TS1 in Scheme S3}

SCF Energy: $\quad-2368.328742$ hartree

SCF Energy + ZPVE: -2368.229502 hartree

Enthalpy: $\quad-2368.217416$ hartree

Free Energy: $\quad-2368.268265$ hartree

Free Energy with quasiharmonic correction: -2368.267341 hartree

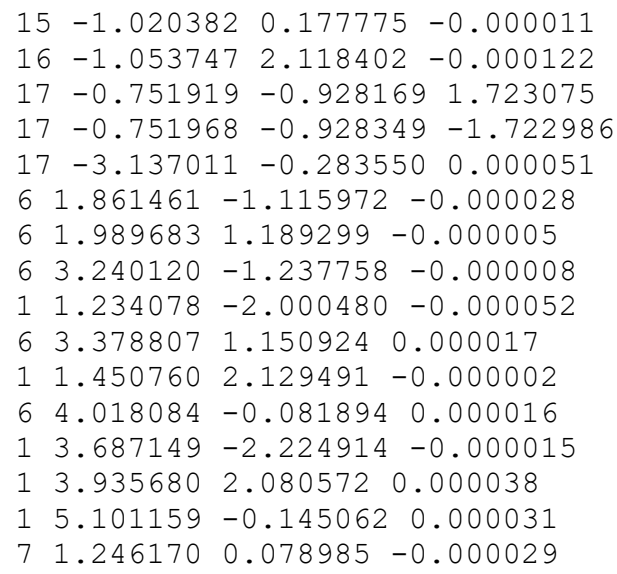

\section{Structure: Adduct in Scheme s3}

SCF Energy: $\quad-2368.328783$ hartree

SCF Energy + ZPVE: -2368.229440 hartree

Enthalpy: $\quad-2368.216567$ hartree

Free Energy: $\quad-2368.269326$ hartree

Free Energy with quasiharmonic correction: -2368.268030 hartree

$\begin{array}{lllll}15 & -0.952655 & 0.179967 & -0.000007 \\ 16 & -1.064080 & 2.123176 & -0.000076 \\ 17 & -0.734822 & -0.916598 & 1.746783 \\ 17 & -0.734841 & -0.916719 & -1.746723 \\ 17 & -3.098505 & -0.310263 & 0.000023 \\ 6 & 1.808756 & -1.117725 & 0.000015 \\ 6 & 1.944648 & 1.193548 & -0.000027 \\ 6 & 3.185208 & -1.240933 & 0.000023 \\ 1 & 1.180058 & -2.000268 & 0.000030 \\ 6 & 3.332274 & 1.146895 & -0.000020 \\ 1 & 1.409364 & 2.134708 & -0.000047 \\ 6 & 3.967075 & -0.087567 & 0.000006 \\ 1 & 3.627872 & -2.229790 & 0.000043 \\ 1 & 3.891193 & 2.075039 & -0.000033 \\ 1 & 5.049752 & -0.154540 & 0.000012 \\ 7 & 1.198280 & 0.082867 & -0.000011\end{array}$ 


\section{Structure: TS2 in Scheme S3}

-2368.325147 hartree SCF Energy + ZPVE: -2368.225763 hartree Enthalpy: $\quad-2368.213610$ hartree Free Energy: $\quad-2368.264670$ hartree

Free Energy with quasiharmonic correction:

$\begin{array}{llll}15 & -0.701144 & 0.215361 & 0.000012\end{array}$

$16-1.0255472 .113533-0.000007$

$17-0.770325-0.916002 \quad 1.700998$

$17-0.770413-0.916045-1.700941$

$17-3.327059-0.2793890 .000083$

$61.810335-1.139052-0.000044$

$\begin{array}{llll}6 & 1.982415 & 1.191997-0.000045\end{array}$

$63.181150-1.273173-0.000070$

$11.168918-2.010902-0.000032$

$\begin{array}{llll}6 & 3.363699 & 1.115685 & -0.000073\end{array}$

$11.4620782 .140309-0.000035$

$63.977766-0.129627-0.000085$

$13.609502-2.267726-0.000079$

$\begin{array}{llll}1 & 3.936603 & 2.034601 & -0.000084\end{array}$

$15.058961-0.212590-0.000106$

$\begin{array}{lllll}7 & 1.221459 & 0.081259 & -0.000032\end{array}$
-2368.263710 hartree

\section{Structure: Product complex in Scheme_s3 \\ SCF Energy: $\quad-2368.338298$ harẼree \\ SCF Energy + ZPVE: -2368.238597 hartree \\ Enthalpy: $\quad-2368.225395$ hartree \\ Free Energy: $\quad-2368.280968$ hartree}

Free Energy with quasiharmonic correction: -2368.277829 hartree

$\begin{array}{llll}15 & -0.237603 & 0.337108 & 0.000104\end{array}$

$\begin{array}{llll}16 & -0.730550 & 2.170315 & 0.000230\end{array}$

$\begin{array}{llll}17 & -0.788654 & -0.768664 & 1.590649\end{array}$

$17-0.788362-0.768284-1.590807$

$17-4.704980-0.348014-0.000144$

$62.017059-1.2428830 .000070$

$\begin{array}{llll}6 & 2.380871 & 1.094825-0.000007\end{array}$

$\begin{array}{llll}6 & 3.371587-1.475294 & 0.000000\end{array}$

$\begin{array}{llll}1 & 1.303464 & -2.058125 & 0.000147\end{array}$

$\begin{array}{llll}6 & 3.745160 & 0.901601 & -0.000066\end{array}$

$11.937600 \quad 2.0822960 .000005$

$64.252229-0.393736-0.000062$

$13.724564-2.498670-0.000004$

$14.3936251 .768516-0.000099$

$15.323166-0.563027-0.000117$

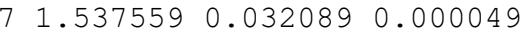

\section{Structure: TS-1a in Figure 6 and S63}

SCF Energy: $\quad-4371.848143$ hartree

SCF Energy + ZPVE: -4371.119790 hartree

Enthalpy: $\quad-4371.070744$ hartree

Free Energy: $\quad-4371.201232$ hartree

Free Energy with quasiharmonic correction: -4371.191651 hartree

$15-1.217365 \quad 2.058791-0.051341$

$\begin{array}{lllll}16 & -0.506131 & 0.815070 & 1.210749\end{array}$

$17-1.621774 \quad 3.959922 \quad 0.505443$

$17-2.384221 \quad 1.916856-1.689495$ 


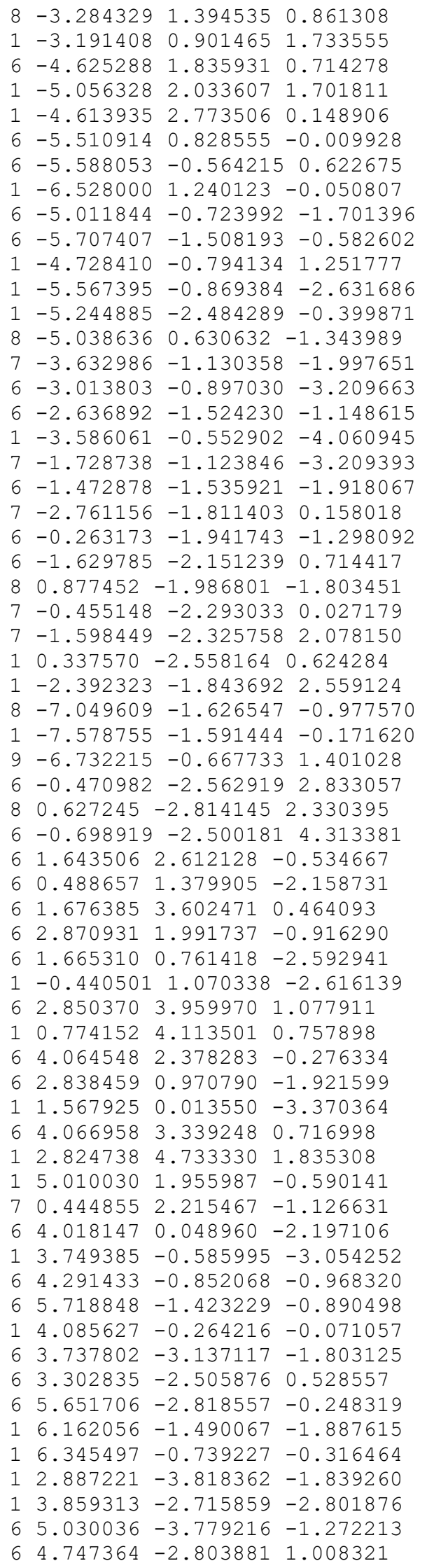




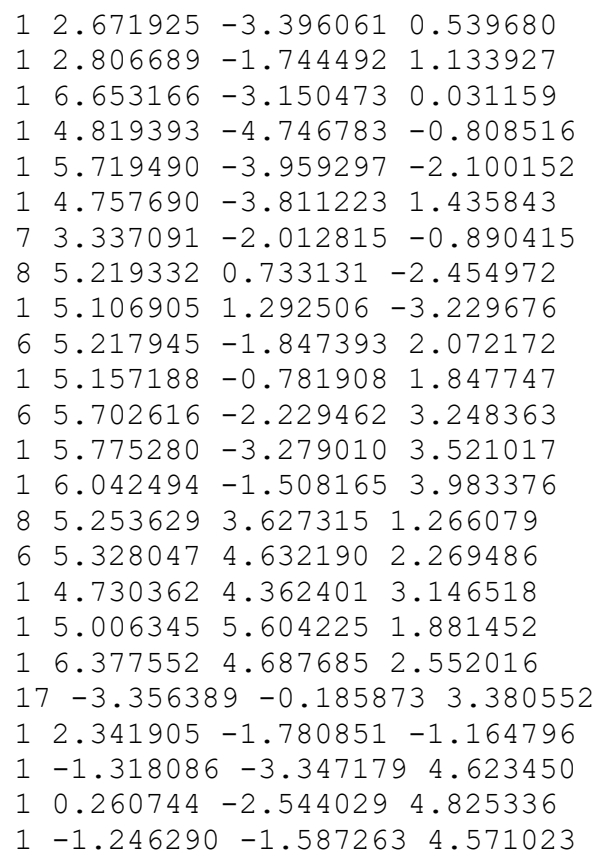

Structure: TS-1b in Figure S63

SCF Energy: $\quad-4371.829046$ hartree SCF Energy + ZPVE: -4371.099126 hartree Enthalpy: $\quad-4371.050265$ hartree Free Energy: $\quad-4371.178860$ hartree

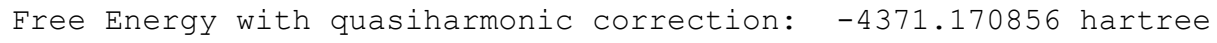

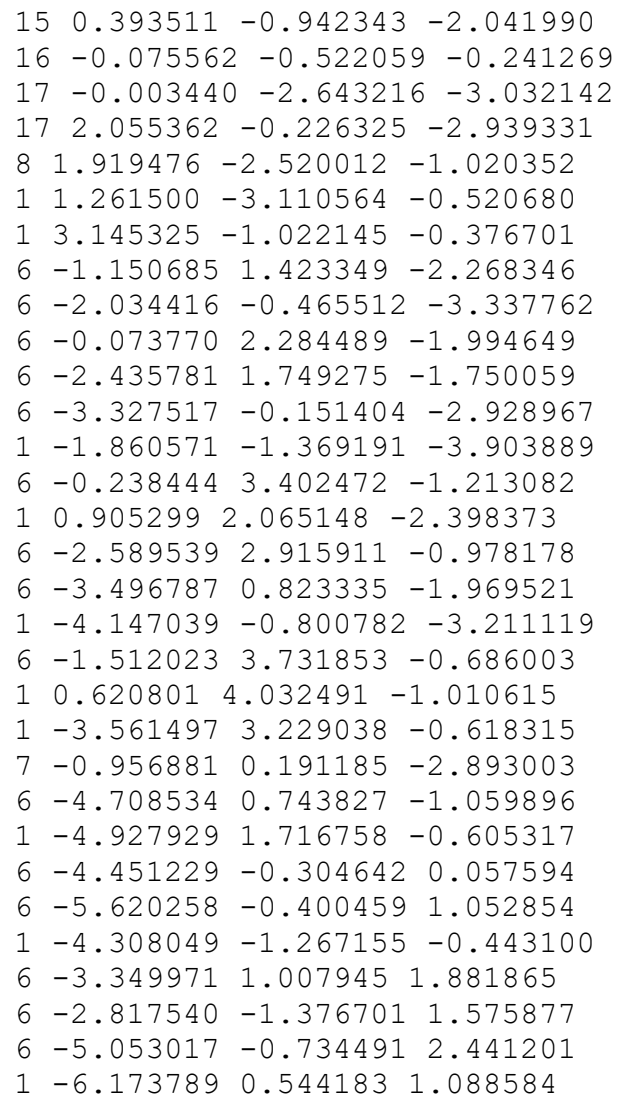


$\begin{array}{llll}1 & -6.311815 & -1.166943 & 0.702907\end{array}$

$\begin{array}{llll}1 & -2.350945 & 1.257798 & 2.249279\end{array}$

$\begin{array}{llll}1 & -3.741673 & 1.882595 & 1.360943\end{array}$

$\begin{array}{llll}6 & -4.303713 & 0.496303 & 2.975719\end{array}$

$\begin{array}{llll}6 & -4.056051 & -1.909759 & 2.317550\end{array}$

$\begin{array}{lllll}1 & -2.007054 & -1.098434 & 2.252919\end{array}$

$\begin{array}{llll}1 & -2.402639 & -2.063932 & 0.835384\end{array}$

$1-5.866649-1.005518 \quad 3.117803$

$\begin{array}{llll}1 & -3.739888 & 0.234916 & 3.874881\end{array}$

$\begin{array}{llll}1 & -5.004873 & 1.288520 & 3.248365\end{array}$

$\begin{array}{lllll}1 & -3.737365 & -2.177426 & 3.332212\end{array}$

$\begin{array}{lllll}7 & -3.194840 & -0.088999 & 0.861086\end{array}$

$\begin{array}{lllll}8 & -5.831720 & 0.227814 & -1.724393\end{array}$

$1-6.2519890 .924049-2.237692$

$\begin{array}{llll}6 & -4.696359 & -3.134065 & 1.700753\end{array}$

$\begin{array}{lllll}1 & -5.720351 & -3.314023 & 2.028955\end{array}$

$\begin{array}{lllll}6 & -4.124125 & -4.009741 & 0.878386\end{array}$

$\begin{array}{lllll}1 & -3.086783 & -3.949704 & 0.551848\end{array}$

$\begin{array}{lllll}1 & -4.682228 & -4.876173 & 0.538752\end{array}$

$\begin{array}{lllll}8 & -1.774837 & 4.817705 & 0.040647\end{array}$

$\begin{array}{llll}6 & -0.704115 & 5.514372 & 0.676502\end{array}$

$\begin{array}{lllll}1 & -0.234321 & 4.856944 & 1.412431\end{array}$

$\begin{array}{llll}1 & -1.169839 & 6.356246 & 1.185071\end{array}$

$10.0276165 .888900-0.044420$

$\begin{array}{llll}17 & -0.279481 & -3.878205 & 0.400845\end{array}$

$\begin{array}{lllll}1 & -2.402058 & 0.134134 & 0.247804\end{array}$

$\begin{array}{lllll}6 & 2.966385 & -2.086104 & -0.195066\end{array}$

$\begin{array}{lllll}6 & 4.277109 & -2.818857 & -0.457594\end{array}$

$\begin{array}{lllll}6 & 5.099998 & -2.512063 & 0.792654\end{array}$

$\begin{array}{lllll}8 & 4.142795 & -2.176016 & 1.816265\end{array}$

$\begin{array}{llll}6 & 2.829349 & -2.301221 & 1.335515\end{array}$

$14.761807-2.516227-1.388850$

$94.014015-4.173860-0.512531$

$15.640475-3.4151921 .095532$

$\begin{array}{lllll}6 & 6.075397 & -1.350480 & 0.641536\end{array}$

$\begin{array}{lllll}1 & 2.389957 & -3.284023 & 1.545119\end{array}$

$\begin{array}{lllll}6 & 0.773379 & -1.567527 & 2.598477\end{array}$

$\begin{array}{lllll}7 & 0.098143 & -0.477207 & 2.862961\end{array}$

$\begin{array}{lllll}7 & 1.999073 & -1.322837 & 2.021016\end{array}$

$\begin{array}{lllll}1 & 0.417351 & -2.580553 & 2.726521\end{array}$

$\begin{array}{lllll}6 & 0.921541 & 0.547325 & 2.445606\end{array}$

$\begin{array}{llll}6 & 2.103022 & 0.035604 & 1.936304\end{array}$

$\begin{array}{lllll}7 & 3.112560 & 0.723439 & 1.349241\end{array}$

$\begin{array}{llll}6 & 2.856829 & 1.989566 & 1.196102\end{array}$

$\begin{array}{llll}7 & 1.709427 & 2.588824 & 1.597057\end{array}$

$\begin{array}{lllll}1 & 1.603067 & 3.569150 & 1.343290\end{array}$

$\begin{array}{llll}6 & 3.695362 & 4.037982 & 0.082292\end{array}$

$\begin{array}{lllll}7 & 3.832387 & 2.754640 & 0.568289\end{array}$

$\begin{array}{lllll}8 & 2.650262 & 4.667371 & 0.193138\end{array}$

$\begin{array}{lllll}1 & 4.684875 & 2.238633 & 0.376177\end{array}$

$6 \quad 4.931888 \quad 4.602433-0.561895$

$14.652326 \quad 5.467158-1.161406$

$\begin{array}{lllll}1 & 5.625745 & 4.927890 & 0.219435\end{array}$

$\begin{array}{lllll}1 & 5.444144 & 3.864776 & -1.184349\end{array}$

$\begin{array}{llll}6 & 0.608644 & 1.924423 & 2.191871\end{array}$

$\begin{array}{lllll}8 & -0.442840 & 2.530048 & 2.351782\end{array}$

$16.859430-1.631086-0.068499$

$\begin{array}{lllll}8 & 5.446162 & -0.188044 & 0.148587\end{array}$

$16.550867-1.172240 \quad 1.615705$

$14.703802 \quad 0.007618 \quad 0.749278$

Structure: TS-a' in Fig. S56

SCF Energy: $\quad-4607.685194$ hartree 


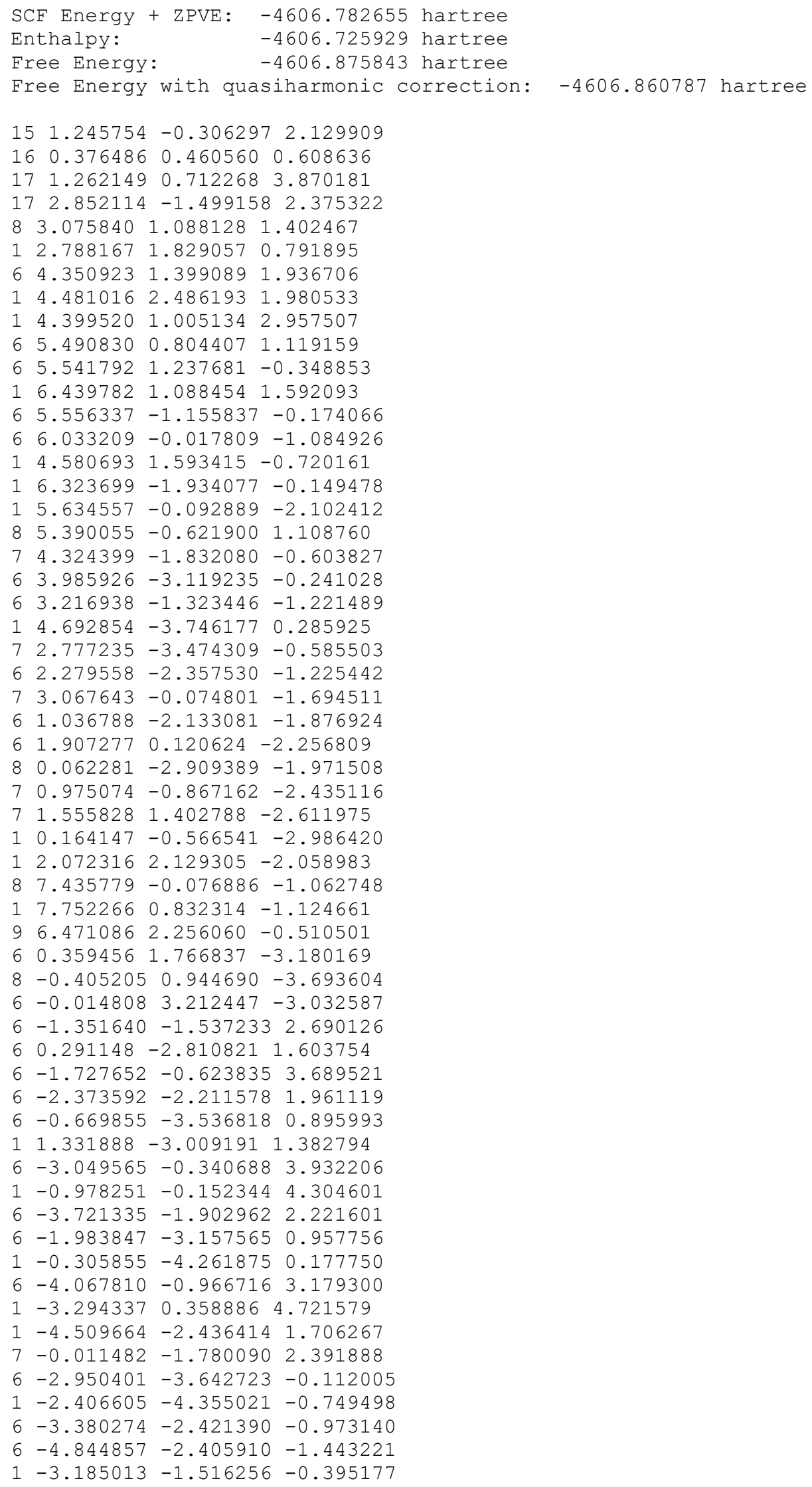




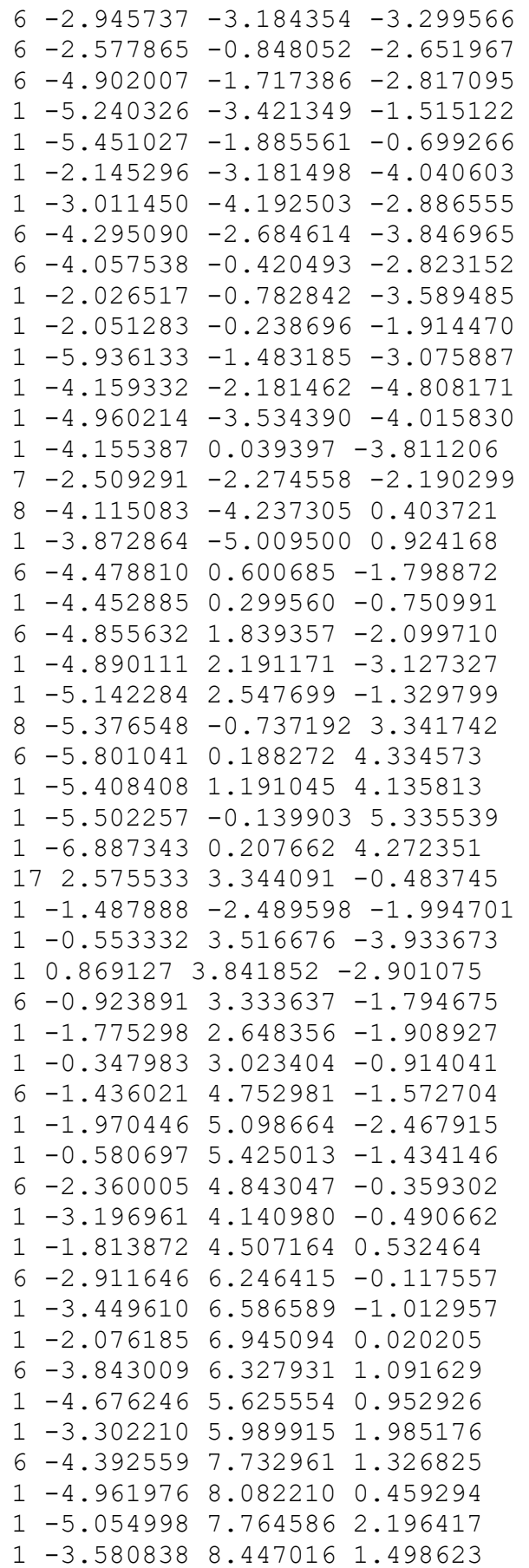

\section{Structure: TS-b' in Fig. S56}

SCF Energy: $\quad-4607.664839$ hartree SCF Energy + ZPVE: $\quad-4606.762667$ hartree Enthalpy: $\quad-4606.706436$ hartree Free Energy: $\quad-4606.853068$ hartree Free Energy with quasiharmonic correction: -4606.840963 hartree

$\begin{array}{llll}15 & -0.870239 & 0.825871 & 2.108917\end{array}$

$\begin{array}{lllll}16 & -1.391336 & 0.466698 & 0.309427\end{array}$

$17-2.0069361 .6124353 .565195$

$\begin{array}{llll}17 & 1.013683 & 1.341550 & 2.623032\end{array}$ 


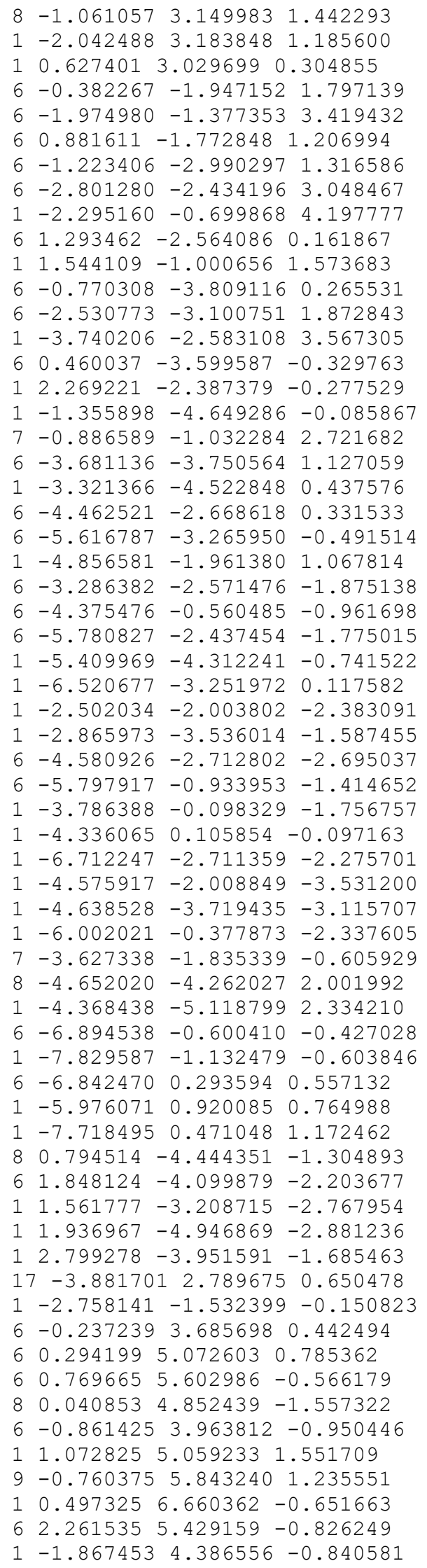




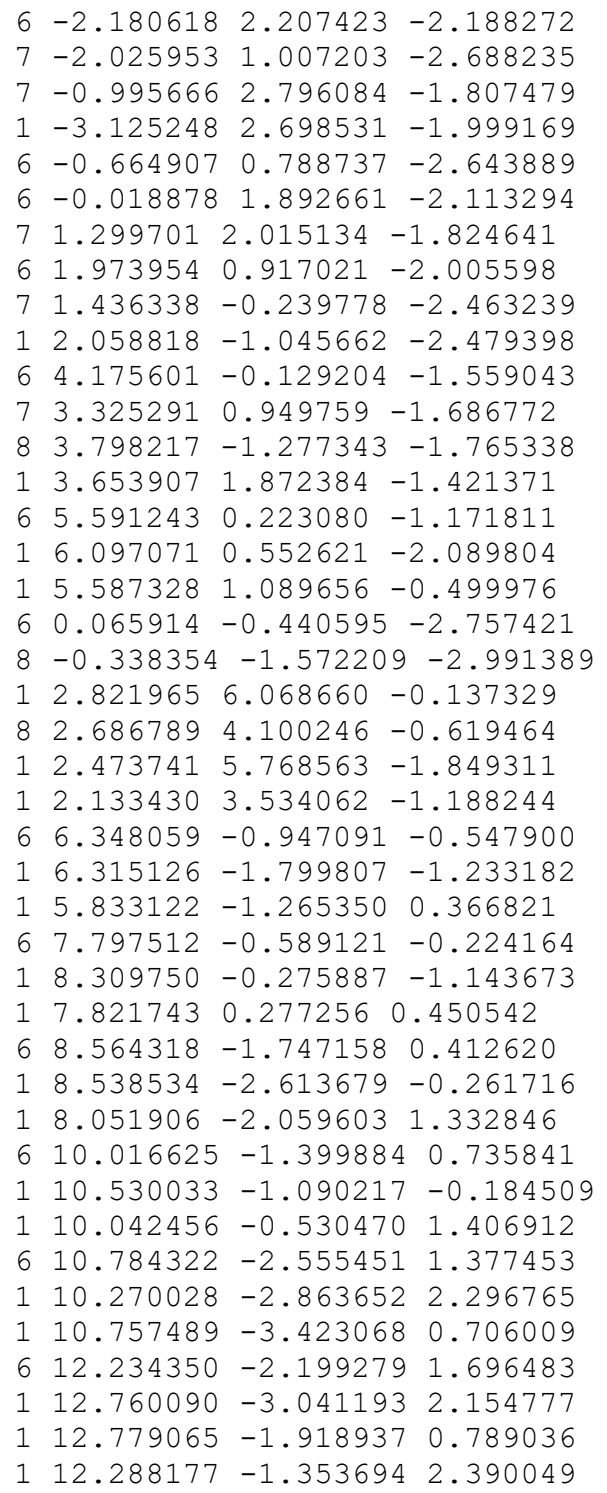

\section{Structure: TS-a" in Fig. S57}

-4067.486402 hartree SCF Energy + ZPVE: $\quad-4066.813361$ hartree Enthalpy: $\quad-4066.769392$ hartree Free Energy: $\quad-4066.889726$ hartree Free Energy with quasiharmonic correction: -4066.880401 hartree
$15 \quad 1.612895-1.691851-0.932754$
$\begin{array}{llll}16 & 1.393750 & -1.601582 & 0.947863\end{array}$
$\begin{array}{llll}17 & 2.036537 & -3.413525 & -1.874837\end{array}$
$\begin{array}{llll}17 & 2.453454 & -0.286073 & -2.100421\end{array}$
$84.077355-1.784793-0.317753$
$\begin{array}{llll}1 & 4.141606 & -2.168253 & 0.608464\end{array}$
$65.279410-1.084711-0.574591$
$16.118063-1.661762-0.167913$
$15.413390-1.015577-1.658969$
$\begin{array}{llll}6 & 5.368969 & 0.312740 & 0.025834\end{array}$
$\begin{array}{lllll}6 & 4.886218 & 0.465433 & 1.471054\end{array}$
$16.4180610 .633386-0.026122$
$\begin{array}{llll}6 & 4.227247 & 2.336013 & 0.117813\end{array}$ 
$\begin{array}{llll}6 & 4.647223 & 1.980205 & 1.555684\end{array}$

$\begin{array}{lllll}1 & 3.946861 & -0.091906 & 1.586730\end{array}$

$\begin{array}{lllll}1 & 4.719135 & 3.252580 & -0.210020\end{array}$

$\begin{array}{lllll}1 & 3.877778 & 2.254061 & 2.293543\end{array}$

$\begin{array}{lllll}8 & 4.557224 & 1.247533 & -0.704837\end{array}$

$\begin{array}{llll}8 & 5.850553 & 2.642108 & 1.822595\end{array}$

$\begin{array}{llll}1 & 6.346482 & 2.047285 & 2.405159\end{array}$

$\begin{array}{llll}8 & 5.816477 & 0.068458 & 2.421096\end{array}$

$6-1.250631-2.172231-0.984862$

$\begin{array}{lllll}6 & -0.507524 & -0.412046 & -2.347654\end{array}$

$6-1.015925-3.400534-0.316972$

$6-2.575111-1.643155-1.000112$

$\begin{array}{lllll}6 & -1.791713 & 0.119549 & -2.438571\end{array}$

$\begin{array}{lllll}1 & 0.310623 & 0.080747 & -2.847797\end{array}$

$\begin{array}{lllll}6 & -2.022811 & -4.029027 & 0.354397\end{array}$

$1-0.042069-3.866353-0.330619$

$6-3.603222-2.318550-0.294139$

$\begin{array}{llll}6 & -2.816259 & -0.426547 & -1.706995\end{array}$

$\begin{array}{lllll}1 & -1.924821 & 1.027010 & -3.015070\end{array}$

$\begin{array}{llll}6 & -3.329147 & -3.477532 & 0.398527\end{array}$

$\begin{array}{lllll}1 & -1.843122 & -4.967786 & 0.865698\end{array}$

$1-4.610185-1.933206-0.355881$

$7-0.220234-1.473579-1.601255$

$6-4.127005 \quad 0.342368-1.605169$

$\begin{array}{lllll}1 & -4.077386 & 1.184357 & -2.312316\end{array}$

$6-4.293833 \quad 0.891406-0.172181$

$\begin{array}{lllll}6 & -5.734641 & 1.235130 & 0.237253\end{array}$

$\begin{array}{lllll}1 & -3.907201 & 0.144843 & 0.522724\end{array}$

$\begin{array}{lllll}6 & -4.119357 & 3.367033 & -0.431389\end{array}$

$\begin{array}{lllll}6 & -3.211035 & 2.237876 & 1.546655\end{array}$

$\begin{array}{llll}6 & -5.676942 & 2.397054 & 1.242272\end{array}$

$1-6.337847 \quad 1.510679-0.632066$

$1-6.1918170 .346006 \quad 0.673780$

$1-3.356949 \quad 4.146235-0.432514$

$1-4.407682 \quad 3.185463-1.467805$

$\begin{array}{lllll}6 & -5.326412 & 3.676165 & 0.468872\end{array}$

$\begin{array}{llll}6 & -4.561178 & 2.134805 & 2.288095\end{array}$

$1-2.724546 \quad 3.201410 \quad 1.705453$

$\begin{array}{llll}1 & -2.502913 & 1.458098 & 1.829285\end{array}$

$\begin{array}{lllll}1 & -6.638473 & 2.508454 & 1.747640\end{array}$

$\begin{array}{llll}1 & -5.097752 & 4.492355 & 1.159712\end{array}$

$1-6.169845 \quad 3.998712-0.145357$

$\begin{array}{lllll}1 & -4.601833 & 2.950561 & 3.019113\end{array}$

$\begin{array}{lllll}7 & -3.449548 & 2.116178 & 0.068491\end{array}$

$8-5.268094-0.437863-1.856954$

$\begin{array}{lllll}1 & -5.223722 & -0.791586 & -2.750852\end{array}$

$\begin{array}{llll}6 & -4.810334 & 0.853015 & 3.049685\end{array}$

$\begin{array}{lllll}1 & -5.760449 & 0.852475 & 3.582394\end{array}$

$6-4.034853-0.2233013 .150479$

$\begin{array}{llll}1 & -3.060680 & -0.315077 & 2.676738\end{array}$

$1-4.340502-1.068590 \quad 3.757322$

$8-4.214131-4.1704341 .117715$

$\begin{array}{llll}6 & -5.536177 & -3.665901 & 1.234512\end{array}$

$\begin{array}{lllll}1 & -6.036484 & -3.642476 & 0.260511\end{array}$

$\begin{array}{lllll}1 & -5.531074 & -2.660994 & 1.674125\end{array}$

$1-6.059620-4.353570 \quad 1.895598$

$\begin{array}{lllll}17 & 4.376258 & -2.613896 & 2.511760\end{array}$

$\begin{array}{llll}1 & -2.502720 & 2.101026 & -0.396943\end{array}$

$\begin{array}{lllll}7 & 0.991830 & 3.507789 & -1.257893\end{array}$

$\begin{array}{lllll}7 & 2.769919 & 2.583329 & -0.042146\end{array}$

$\begin{array}{llll}6 & 1.864262 & 1.779489 & 0.563041\end{array}$

$\begin{array}{lllll}6 & 0.528802 & 1.813169 & 0.310473\end{array}$

$\begin{array}{llll}1 & 2.273092 & 1.063358 & 1.264961\end{array}$ 


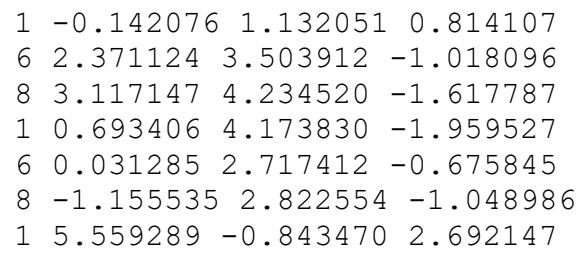


$\begin{array}{llll}1 & -6.121852 & -0.213385 & 3.530554 \\ 8 & -4.709298 & -3.856037 & 1.076125 \\ 6 & -5.979229 & -3.222043 & 1.075087 \\ 1 & -6.423890 & -3.230751 & 0.074105 \\ 1 & -5.899197 & -2.189464 & 1.437006 \\ 1 & -6.601759 & -3.801813 & 1.753667 \\ 17 & 3.023887 & -0.643194 & 3.435264 \\ 1 & -2.228202 & 2.045508 & -0.602108 \\ 6 & 4.451836 & -0.257697 & 0.282556 \\ 6 & 5.892057 & -0.480004 & 0.768766 \\ 6 & 6.457863 & 0.959395 & 0.646654 \\ 8 & 5.322970 & 1.866903 & 0.664432 \\ 6 & 4.173547 & 1.125069 & 0.906282 \\ 1 & 4.508592 & -0.150140 & -0.799479 \\ 1 & 6.424501 & -1.148787 & 0.087405 \\ 8 & 6.005181 & -1.022644 & 2.050230 \\ 1 & 7.084794 & 1.166350 & 1.519899 \\ 6 & 7.218602 & 1.228157 & -0.642424 \\ 1 & 3.973410 & 1.005435 & 1.975953 \\ 7 & 1.525344 & 2.392881 & -1.339553 \\ 7 & 2.976163 & 1.814104 & 0.387548 \\ 6 & 1.965418 & 2.087123 & 1.262627 \\ 6 & 0.728191 & 2.488711 & 0.873347 \\ 1 & 2.199605 & 1.880433 & 2.303389 \\ 1 & -0.047338 & 2.654657 & 1.606023 \\ 8 & 6.449958 & 0.926331 & -1.783866 \\ 1 & 7.553211 & 2.275067 & -0.644355 \\ 1 & 8.109008 & 0.592918 & -0.672115 \\ 1 & 5.690075 & 1.524165 & -1.786257 \\ 1 & 5.246580 & -0.800894 & 2.617425 \\ 6 & 2.829144 & 2.070845 & -0.969766 \\ 8 & 3.703130 & 1.980217 & -1.804276 \\ 1 & 1.392580 & 2.526908 & -2.333551 \\ 6 & 0.422626 & 2.529861 & -0.521794 \\ 8 & -0.700571 & 2.651240 & -1.047376\end{array}$

Structure: TS-c" in Fig. S57

SCF Energy: $\quad-4067.460225$ hartree SCF Energy + ZPVE: -4066.787168 hartree Enthalpy: $\quad-4066.742398$ hartree Free Energy: $\quad-4066.866580$ hartree

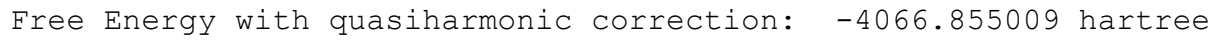
$\begin{array}{lllll}15 & 0.480845 & 1.126461 & -0.553440\end{array}$
$\begin{array}{llll}16 & 1.593974 & 2.664385 & -0.617701\end{array}$
$\begin{array}{llll}17 & -0.573567 & 0.650056 & 1.113435\end{array}$
$170.831148-0.409725-1.789256$
$8 \quad 1.941139-0.2130320 .744186$
$\begin{array}{llll}1 & 1.437870 & -1.073064 & 0.840185\end{array}$
$6-2.261500 \quad 2.292890-0.730164$
$6-1.690297 \quad 0.883165-2.490841$
$\begin{array}{lllll}6 & -1.898396 & 3.337786 & 0.139786\end{array}$
$6-3.6363191 .938258-0.855838$
$6-3.0308790 .558992-2.724343$
$\begin{array}{lllll}1 & -0.922664 & 0.442812 & -3.109098\end{array}$
$\begin{array}{lllll}6 & -2.849793 & 3.999650 & 0.873866\end{array}$
$\begin{array}{lllll}1 & -0.860700 & 3.639328 & 0.210939\end{array}$
$\begin{array}{llll}6 & -4.589680 & 2.613678 & -0.069940\end{array}$
$\begin{array}{lllll}6 & -3.978363 & 0.918943 & -1.796834\end{array}$
$1-3.266995-0.112578-3.539465$
$\begin{array}{llll}6 & -4.214938 & 3.631951 & 0.788117\end{array}$
$\begin{array}{llll}1 & -2.538670 & 4.816521 & 1.512916\end{array}$
$1-5.6463852 .389443-0.149670$ 


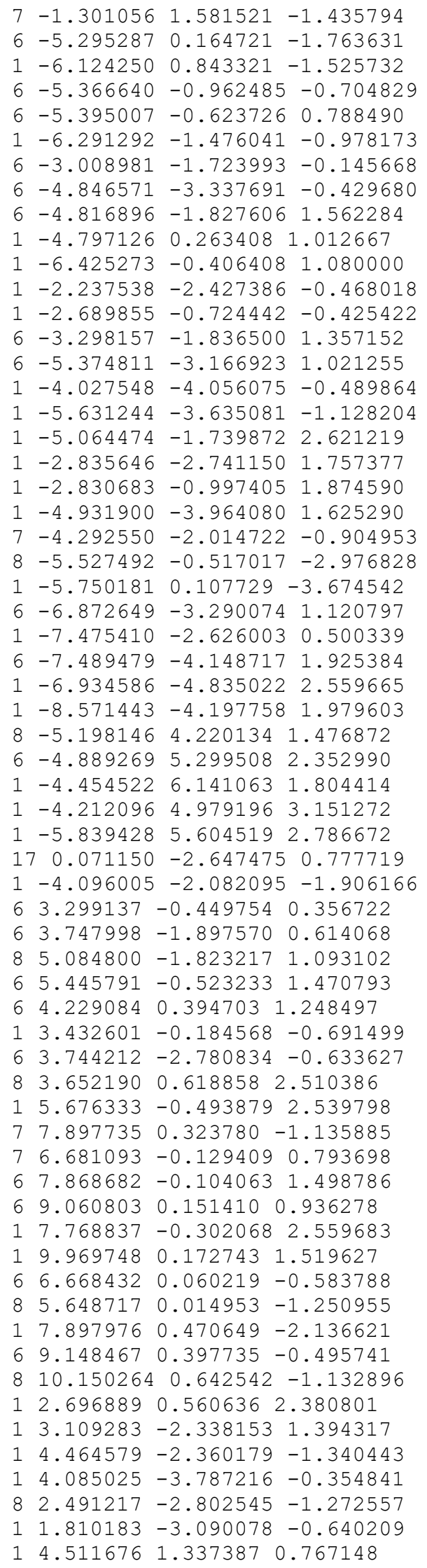




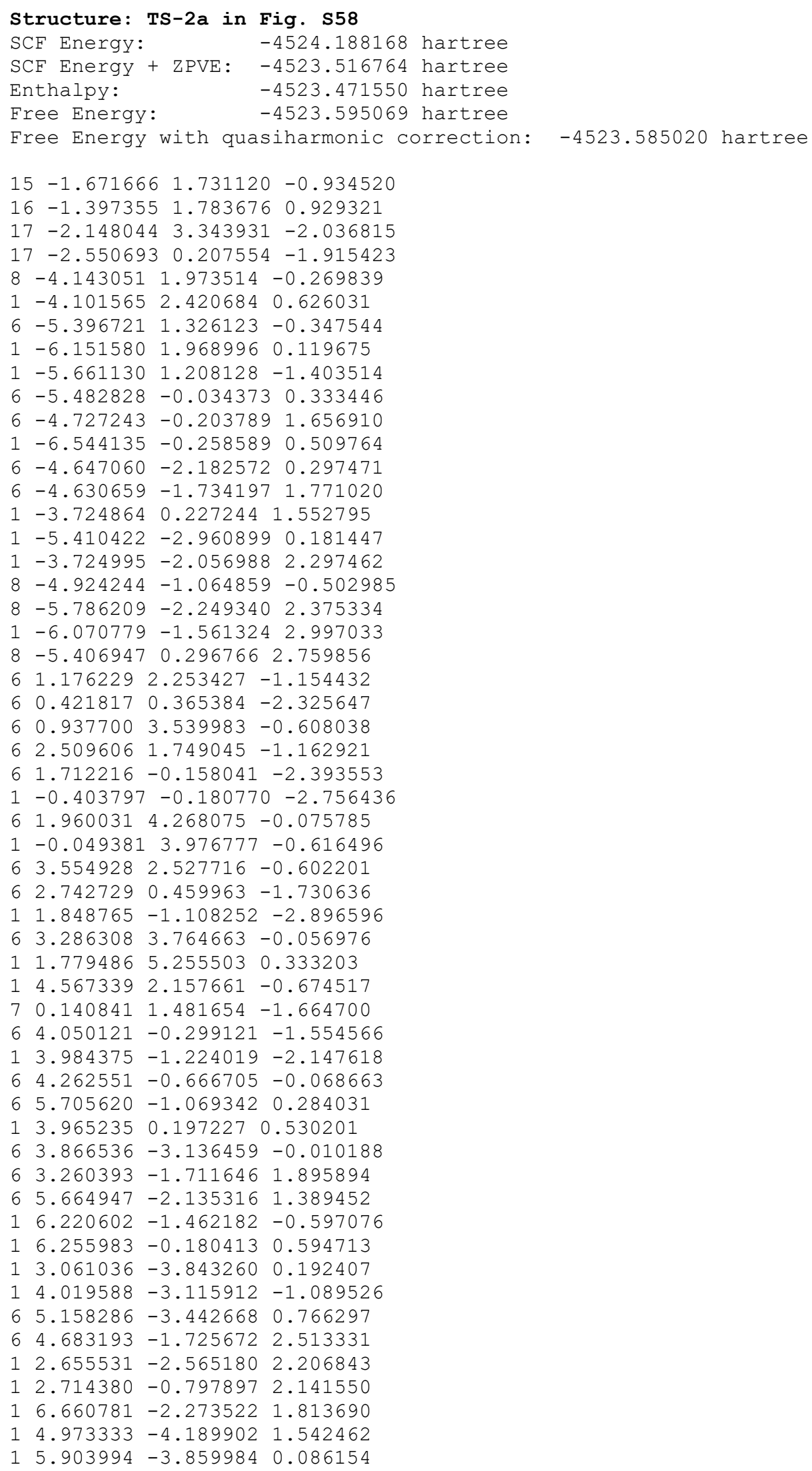




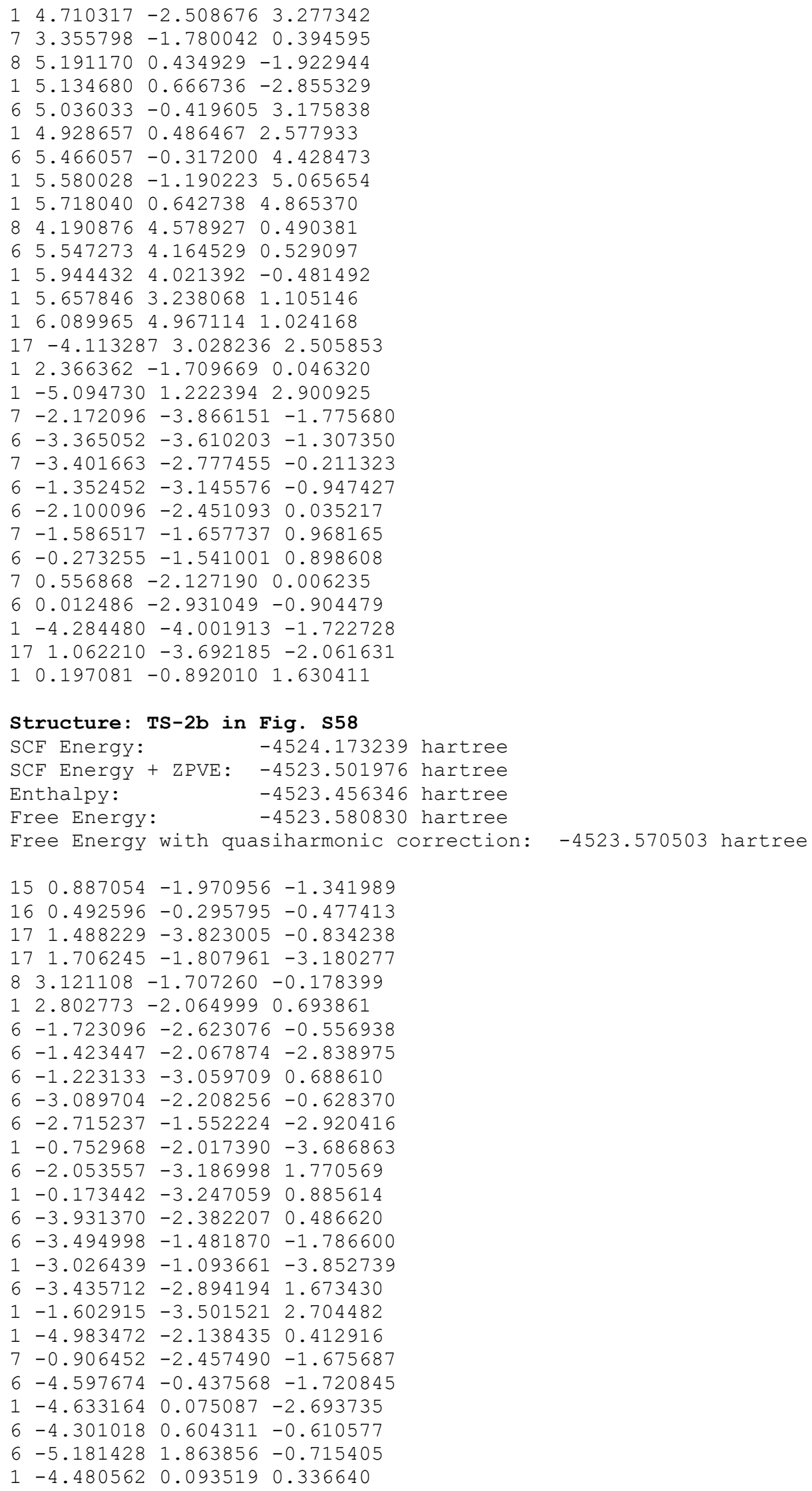




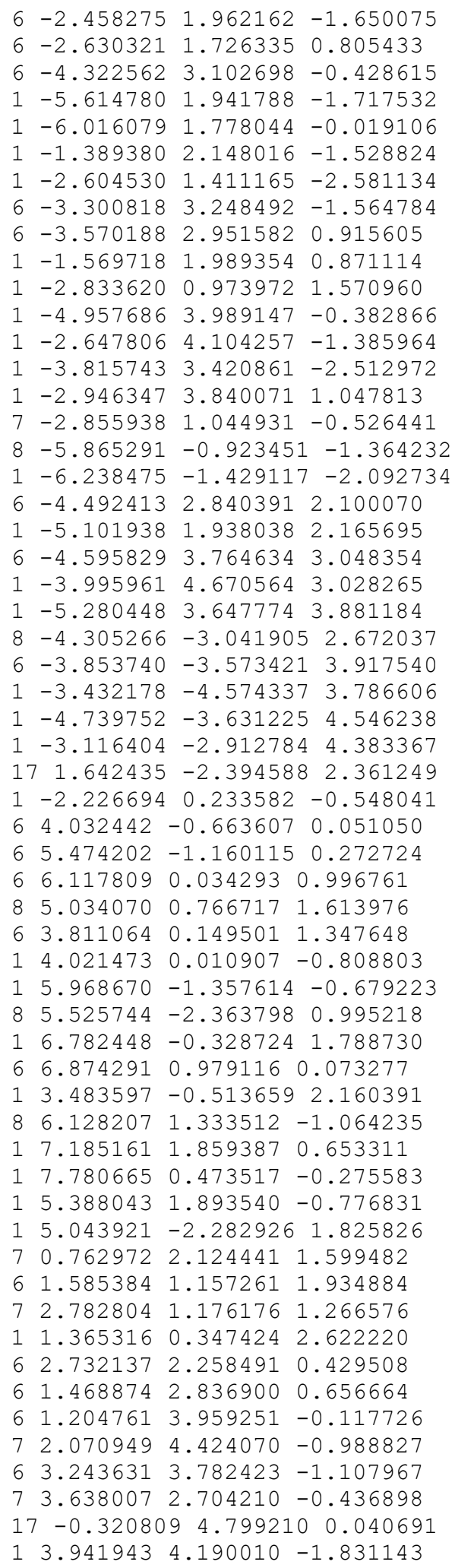

Structure: TS-2C in Fig. S58 


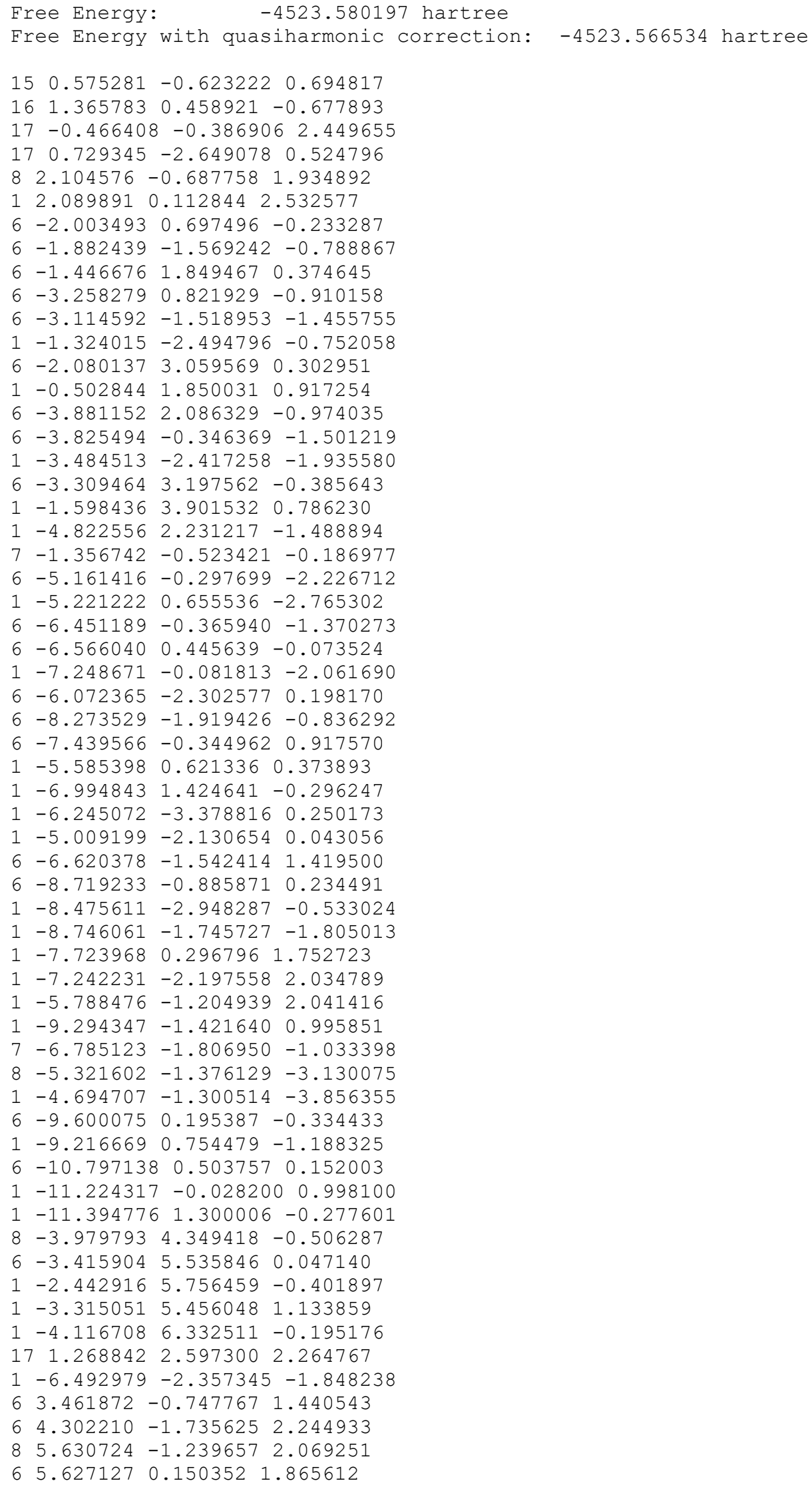


$\begin{array}{llll}6 & 4.157117 & 0.594312 & 1.707780 \\ 1 & 3.437988 & -1.025697 & 0.388494 \\ 6 & 4.244532 & -3.172508 & 1.745551 \\ 8 & 3.688782 & 1.077452 & 2.935693 \\ 1 & 6.059749 & 0.681758 & 2.719834 \\ 1 & 3.054365 & 1.825626 & 2.774057 \\ 1 & 4.022642 & -1.689672 & 3.306205 \\ 1 & 5.088450 & -3.716030 & 2.193872 \\ 1 & 3.321664 & -3.629481 & 2.118464 \\ 8 & 4.224206 & -3.274300 & 0.347976 \\ 1 & 4.913118 & -2.689390 & -0.012071 \\ 1 & 4.018449 & 1.316294 & 0.898500 \\ 6 & 7.393938 & 1.466490 & 0.636053 \\ 7 & 7.952550 & 1.600161 & -0.532111 \\ 7 & 6.460277 & 0.453100 & 0.714910 \\ 1 & 7.613919 & 2.078406 & 1.501320 \\ 6 & 7.361327 & 0.615947 & -1.290896 \\ 6 & 6.429725 & -0.114877 & -0.534093 \\ 7 & 5.696718 & -1.134367 & -0.981667 \\ 6 & 5.920968 & -1.407499 & -2.266103 \\ 7 & 6.768585 & -0.787616 & -3.095609 \\ 6 & 7.487955 & 0.211949 & -2.619172 \\ 1 & 5.354128 & -2.230903 & -2.689445 \\ 17 & 8.586529 & 1.011534 & -3.683701\end{array}$

\section{Structure: TS-3a in Fig. S59}

SCF Energy: $\quad-4642.126994$ hartree SCF Energy + ZPVE: -4641.286104 hartree Enthalpy: $\quad-4641.231497$ hartree Free Energy: $\quad-4641.373592$ hartree Free Energy with quasiharmonic correction: -4641.362640 hartree

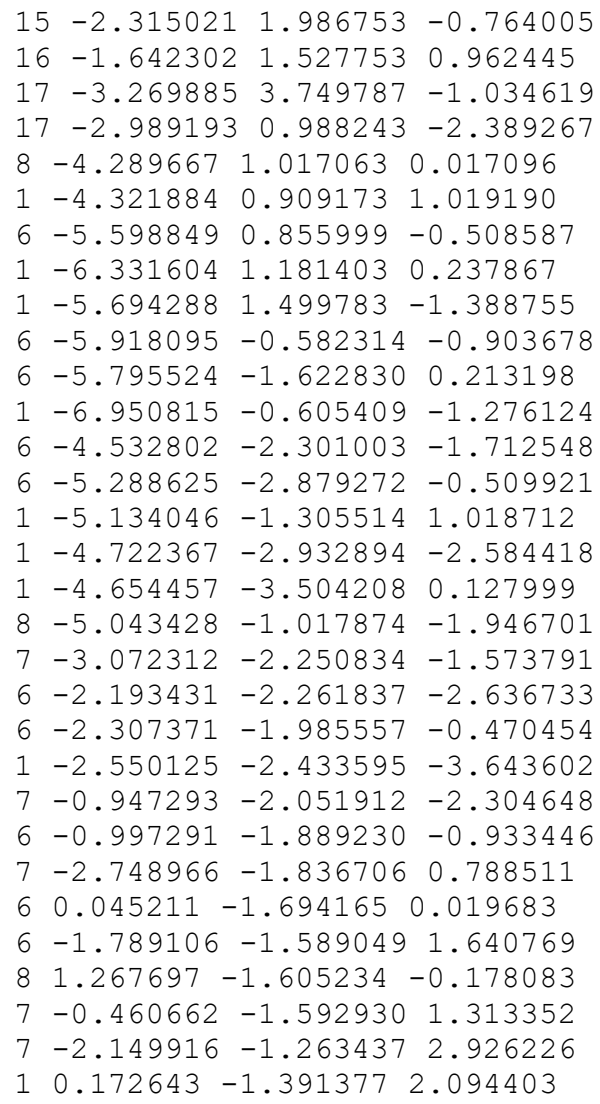


$\begin{array}{llll}1 & -3.142184 & -0.946892 & 2.993812\end{array}$

$8-6.367609-3.600477-1.047240$

$1-7.102538-3.495017-0.431148$

$\begin{array}{lllll}9 & -7.046527 & -1.881680 & 0.757081\end{array}$

$\begin{array}{lllll}6 & -1.298235 & -0.846608 & 3.926279\end{array}$

$8-0.074654-0.884328 \quad 3.808396$

$\begin{array}{lllll}6 & -1.993899 & -0.361834 & 5.163646\end{array}$

$\begin{array}{lllll}6 & 0.385309 & 3.195087 & -1.117505\end{array}$

$6-0.072701 \quad 1.176375-2.207246$

$\begin{array}{lllll}6 & -0.042044 & 4.409642 & -0.531741\end{array}$

$\begin{array}{llll}6 & 1.788336 & 2.927912 & -1.180445\end{array}$

$\begin{array}{lllll}6 & 1.276473 & 0.865440 & -2.295067\end{array}$

$\begin{array}{lllll}6 & 0.859872 & 5.312367 & -0.049230\end{array}$

$1-1.091216 \quad 4.647252-0.466588$

$\begin{array}{lllll}6 & 2.703725 & 3.892495 & -0.686641\end{array}$

$\begin{array}{lllll}6 & 2.218386 & 1.680191 & -1.718060\end{array}$

$\begin{array}{lllll}6 & 2.252185 & 5.064003 & -0.123226\end{array}$

$\begin{array}{lllll}1 & 0.527263 & 6.244554 & 0.392791\end{array}$

$\begin{array}{lllll}1 & 3.758557 & 3.687784 & -0.785410\end{array}$

$\begin{array}{llll}7 & -0.529582 & 2.266855 & -1.595803\end{array}$

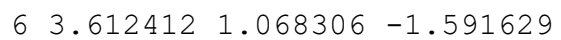

$\begin{array}{lllll}1 & 3.649088 & 0.307989 & -2.374974\end{array}$

$\begin{array}{lllll}6 & 3.681539 & 0.370786 & -0.209106\end{array}$

$\begin{array}{lllll}6 & 4.148664 & 1.312418 & 0.919617\end{array}$

$\begin{array}{lllll}1 & 2.683962 & -0.025170 & -0.003324\end{array}$

$66.007466-0.539910-0.193094$

$\begin{array}{lllll}6 & 4.216832 & -1.633230 & 1.098816\end{array}$

$\begin{array}{lllll}6 & 5.088845 & 0.565927 & 1.864606\end{array}$

$\begin{array}{lllll}1 & 4.683387 & 2.164639 & 0.499380\end{array}$

$13.272938 \quad 1.695932 \quad 1.446967$

$16.556753-1.477103-0.285599$

$\begin{array}{lllll}1 & 6.176027 & 0.063409 & -1.086291\end{array}$

$\begin{array}{lllll}6 & 6.369750 & 0.221877 & 1.095829\end{array}$

$\begin{array}{llll}6 & 4.434191 & -0.740469 & 2.340076\end{array}$

$14.858727-2.512496 \quad 1.114717$

$\begin{array}{lllll}1 & 3.177817 & -1.953354 & 1.001578\end{array}$

$\begin{array}{llll}1 & 5.322817 & 1.192755 & 2.727675\end{array}$

$17.030668-0.3842891 .720859$

$16.912375 \quad 1.133697 \quad 0.835219$

$15.145798-1.245701 \quad 3.001592$

$74.545920-0.899106-0.190208$

$\begin{array}{lllll}8 & 4.711006 & 1.938231 & -1.745940\end{array}$

$\begin{array}{lllll}1 & 4.723349 & 2.264437 & -2.651267\end{array}$

$\begin{array}{lllll}6 & 3.152147 & -0.538466 & 3.102080\end{array}$

$\begin{array}{lllll}1 & 2.286629 & -0.197494 & 2.533485\end{array}$

$\begin{array}{lllll}6 & 3.016135 & -0.769676 & 4.403029\end{array}$

$13.848086-1.1255925 .006344$

$\begin{array}{lllll}1 & 2.058834 & -0.626743 & 4.890747\end{array}$

$\begin{array}{lllll}8 & 3.029225 & 6.033664 & 0.375452\end{array}$

$\begin{array}{lllll}6 & 4.434424 & 5.852126 & 0.349737\end{array}$

$14.803480 \quad 5.767834-0.678586$

$14.726394 \quad 4.963076 \quad 0.921020$

$\begin{array}{lllll}1 & 4.859291 & 6.739012 & 0.815908\end{array}$

$\begin{array}{lllll}17 & -4.704005 & 0.452510 & 2.890884\end{array}$

$\begin{array}{lllll}6 & 4.197622 & -1.799638 & -1.378508\end{array}$

$\begin{array}{lllll}1 & -2.779614 & 0.353629 & 4.899763\end{array}$

$\begin{array}{lllll}1 & -1.261139 & 0.085762 & 5.832917\end{array}$

$\begin{array}{lllll}1 & -2.479383 & -1.205104 & 5.663787\end{array}$

$11.525245-0.096399-2.728481$

$\begin{array}{lllll}1 & -0.777979 & 0.445767 & -2.571215\end{array}$

$13.110565-1.739778-1.472934$

$14.683672-1.353307-2.247483$

$\begin{array}{lllll}6 & 5.335808 & -5.924639 & -1.023012\end{array}$ 


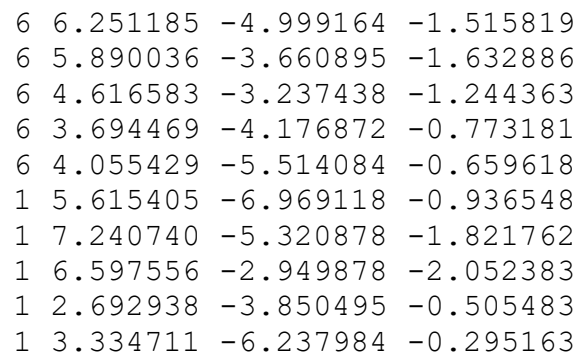


$\begin{array}{lllll}6 & 3.677556 & 6.020191 & -1.760540\end{array}$

$\begin{array}{lllll}1 & 4.680256 & 6.439767 & -1.792474\end{array}$

$\begin{array}{lllll}1 & 2.856437 & 6.702722 & -1.950715\end{array}$

$\begin{array}{lllll}8 & 4.441842 & -5.282561 & 0.986639\end{array}$

$\begin{array}{lllll}6 & 4.318073-6.573244 & 1.570940\end{array}$

$\begin{array}{lllll}1 & 3.673592 & -6.548089 & 2.455781\end{array}$

$\begin{array}{llll}1 & 5.325585 & -6.858345 & 1.867592\end{array}$

$13.934434-7.3004130 .847906$

$\begin{array}{lllll}17 & -4.068974 & -0.421814 & 2.667477\end{array}$

$\begin{array}{llll}6 & 4.837130 & 0.950863 & 1.380665\end{array}$

$6-4.458868-0.337503-0.574246$

$6-5.918348-0.597529-0.888482$

$\begin{array}{lllll}6 & -6.304664 & 0.701176 & -1.586587\end{array}$

$8-5.073051 \quad 1.217525-2.152754$

$\begin{array}{lllll}6 & -4.024144 & 0.319700 & -1.904814\end{array}$

$1-6.510933-0.827234 \quad 0.000091$

$9-6.010136-1.657862-1.776206$

$\begin{array}{lllll}1 & -7.000691 & 0.506619 & -2.407121\end{array}$

$6-6.8634951 .769920-0.654188$

$\begin{array}{llll}1 & -3.946224 & -0.409359 & -2.716249\end{array}$

$\begin{array}{llll}6 & -1.776877 & 0.999836 & -2.836552\end{array}$

$\begin{array}{lllll}7 & -0.651977 & 1.548633 & -2.458684\end{array}$

$7-2.7630651 .033776-1.870765$

$\begin{array}{lllll}1 & -1.962968 & 0.550340 & -3.803208\end{array}$

$\begin{array}{lllll}6 & -0.909192 & 1.996731 & -1.176701\end{array}$

$6-2.215599-1.709495-0.813841$

$\begin{array}{lllll}7 & -2.815903 & 1.910771 & 0.367777\end{array}$

$6-2.000106 \quad 2.336496 \quad 1.291569$

$\begin{array}{llll}7 & -0.696211 & 2.674946 & 1.055623\end{array}$

$\begin{array}{lllll}1 & -0.173651 & 3.026584 & 1.859196\end{array}$

$\begin{array}{llll}6 & -1.848954 & 2.779279 & 3.706981\end{array}$

$\begin{array}{lllll}7 & -2.491189 & 2.331829 & 2.575809\end{array}$

$\begin{array}{lllll}8 & -0.783444 & 3.383267 & 3.653557\end{array}$

$\begin{array}{llll}1 & -3.275487 & 1.663425 & 2.673502\end{array}$

$\begin{array}{llll}6 & -2.578471 & 2.474543 & 4.984982\end{array}$

$\begin{array}{lllll}1 & -3.436274 & 3.146969 & 5.081267\end{array}$

$\begin{array}{llll}1 & -2.960689 & 1.449222 & 4.979523\end{array}$

$\begin{array}{lllll}6 & -0.025237 & 2.500377 & -0.166742\end{array}$

$\begin{array}{lllll}8 & 1.182626 & 2.723835 & -0.248654\end{array}$

$\begin{array}{llll}1 & -6.218891 & 1.858015 & 0.234807\end{array}$

$\begin{array}{llll}8 & -7.000638 & 2.994075 & -1.324034\end{array}$

$1-7.859472 \quad 1.469315-0.316613$

$1-6.127645 \quad 3.225095-1.658273$

$\begin{array}{llll}1 & -1.906790 & 2.634279 & 5.827005\end{array}$

$\begin{array}{lllll}1 & 5.516898 & 1.616871 & 1.916669\end{array}$

$\begin{array}{lllll}1 & 5.342279 & -0.011367 & 1.287539\end{array}$

$\begin{array}{llll}6 & 1.092521 & 0.512788 & 3.450565\end{array}$

$\begin{array}{lllll}6 & 1.663411 & -0.578617 & 2.803082\end{array}$

$\begin{array}{lllll}6 & 2.880394 & -0.434981 & 2.146176\end{array}$

$\begin{array}{lllll}6 & 3.529741 & 0.802134 & 2.110178\end{array}$

$\begin{array}{lllll}6 & 2.965797 & 1.880301 & 2.796502\end{array}$

$\begin{array}{lllll}6 & 1.757211 & 1.736807 & 3.466338\end{array}$

$\begin{array}{lllll}1 & 0.141706 & 0.403297 & 3.962434\end{array}$

$\begin{array}{llll}1 & 1.169539 & -1.544455 & 2.819750\end{array}$

$\begin{array}{lllll}1 & 3.332939 & -1.306847 & 1.683772\end{array}$

$\begin{array}{llll}1 & 3.477160 & 2.837794 & 2.823442\end{array}$

$11.321472 \quad 2.577442 \quad 3.993069$

$\begin{array}{lllll}1 & 1.596494 & 0.079934 & -2.390017\end{array}$

$1-0.520605-0.963890-2.221126$

Structure: TS-4a in Fig. S60

SCF Energy: $\quad-3890.817566$ hartree

SCF Energy + ZPVE: $\quad-3890.320148$ hartree 


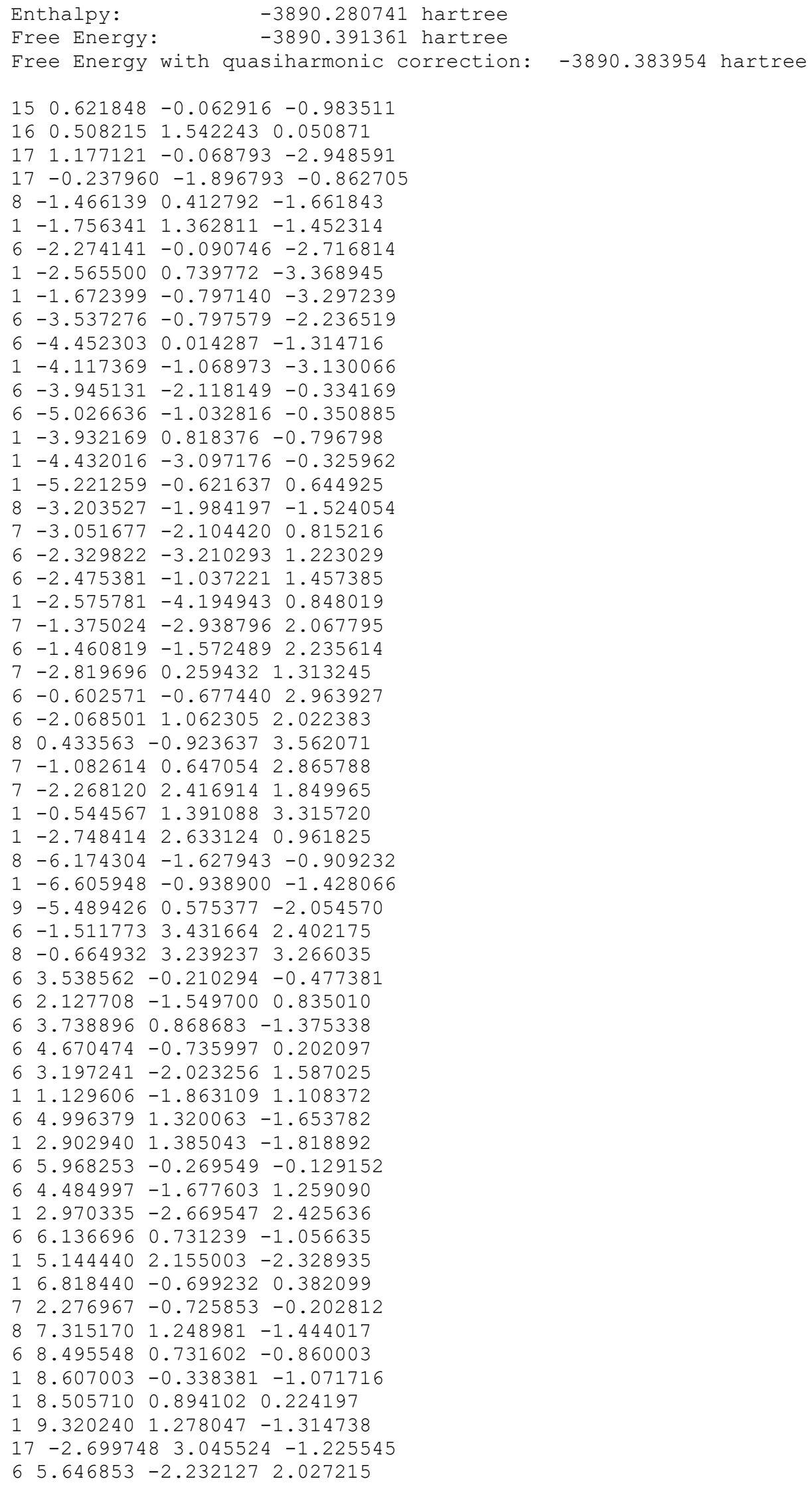


$16.336266-2.763427 \quad 1.363474$

$16.207404-1.4291662 .516118$

$15.307019-2.927078 \quad 2.795655$

$6-1.834675 \quad 4.794265 \quad 1.852661$

$\begin{array}{lllll}1 & -2.855211 & 5.073739 & 2.130280\end{array}$

$\begin{array}{lllll}1 & -1.131344 & 5.515630 & 2.265395\end{array}$

$\begin{array}{lllll}1 & -1.788421 & 4.777178 & 0.758731\end{array}$

Structure: TS-4b in Fig. S60

SCF Energy: $\quad-3890.807833$ hartree

SCF Energy + ZPVE: $\quad-3890.312686$ hartree

Enthalpy: $\quad-3890.272933$ hartree

Free Energy: $\quad-3890.385961$ hartree

Free Energy with quasiharmonic correction: -3890.376696 hartree

$15-0.641206-2.186571-0.417262$

$16-0.914994-2.742169 \quad 1.381854$

$17-0.309067-3.536358-1.901489$

$17-0.130078-0.381213-1.269053$

$81.577115-2.408201-0.202459$

$\begin{array}{lllll}1 & 1.793091 & -3.131331 & 0.584521\end{array}$

$12.239300-0.569286-0.786742$

$\begin{array}{lllll}6 & -3.153641 & -0.704491 & -0.269026\end{array}$

$6-3.174388-2.514770-1.764934$

$\begin{array}{lllll}6 & -2.528227 & 0.086206 & 0.720955\end{array}$

$6-4.496180-0.386090-0.629189$

$\begin{array}{llll}6 & -4.502627 & -2.270948 & -2.114199\end{array}$

$1-2.643606-3.340924-2.213636$

$\begin{array}{llll}6 & -3.165067 & 1.156918 & 1.289482\end{array}$

$1-1.541188-0.135298 \quad 1.094080$

$\begin{array}{lllll}6 & -5.128101 & 0.726498 & -0.037696\end{array}$

$6-5.181783-1.204776-1.577268$

$1-4.974759-2.934783-2.828570$

$\begin{array}{llll}6 & -4.476092 & 1.509238 & 0.893236\end{array}$

$1-2.6238291 .732896 \quad 2.031871$

$1-6.1420110 .991681-0.309183$

$\begin{array}{llll}7 & -2.505517 & -1.766347 & -0.900615\end{array}$

$6-6.599432-0.919141-1.971285$

$\begin{array}{lllll}1 & -6.684371 & 0.076577 & -2.417259\end{array}$

$\begin{array}{lllll}8 & -5.143147 & 2.564933 & 1.380096\end{array}$

$\begin{array}{lllll}6 & -4.482297 & 3.406946 & 2.322118\end{array}$

$\begin{array}{llll}1 & -4.282270 & 2.869284 & 3.254865\end{array}$

$\begin{array}{lllll}1 & -5.175635 & 4.223782 & 2.516879\end{array}$

$\begin{array}{lllll}1 & -3.542075 & 3.797357 & 1.922584\end{array}$

$\begin{array}{llll}17 & 2.212144 & -4.085451 & 1.966600\end{array}$

$\begin{array}{lllll}6 & 2.567508 & -1.417740 & -0.184497\end{array}$

$\begin{array}{lllll}6 & 3.930716 & -1.805475 & -0.754074\end{array}$

$64.866823-0.785106-0.086447$

$\begin{array}{lllll}8 & 4.156183 & -0.225518 & 1.032564\end{array}$

$\begin{array}{lllll}6 & 2.927590 & -0.881959 & 1.211972\end{array}$

$13.951854-1.744958-1.845742$

$\begin{array}{lllll}9 & 4.287173 & -3.079657 & -0.383827\end{array}$

$\begin{array}{lllll}1 & 5.748344 & -1.321513 & 0.282677\end{array}$

$\begin{array}{lllll}6 & 5.296383 & 0.364289 & -0.989341\end{array}$

$\begin{array}{lllll}1 & 2.983353 & -1.701373 & 1.938377\end{array}$

$\begin{array}{llll}6 & 1.001566 & -0.172392 & 2.682879\end{array}$

$\begin{array}{lllll}7 & 0.119088 & 0.786217 & 2.804348\end{array}$

$\begin{array}{lllll}7 & 1.942236 & 0.068140 & 1.704480\end{array}$

$11.027075-1.0955353 .246618$

$\begin{array}{llll}6 & 0.497929 & 1.716053 & 1.860562\end{array}$

$\begin{array}{llll}6 & 1.616184 & 1.281255 & 1.171247\end{array}$

$\begin{array}{llll}7 & 2.243614 & 1.906842 & 0.144358\end{array}$

$\begin{array}{lllll}6 & 1.693960 & 3.039808 & -0.190022\end{array}$ 


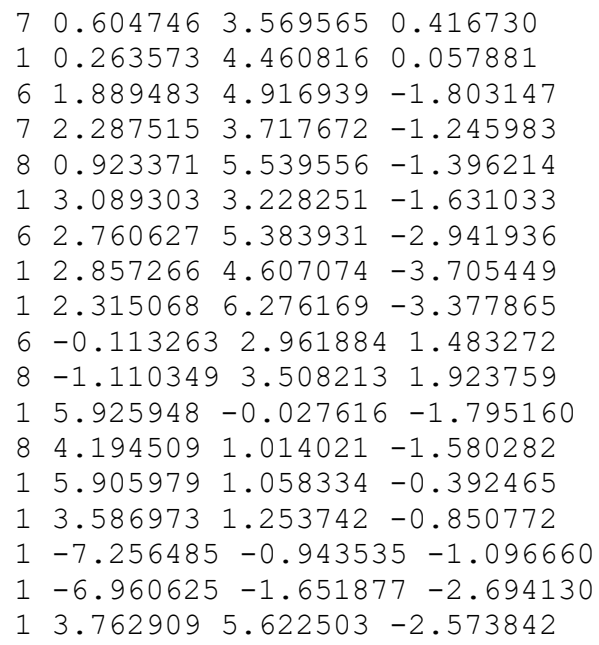




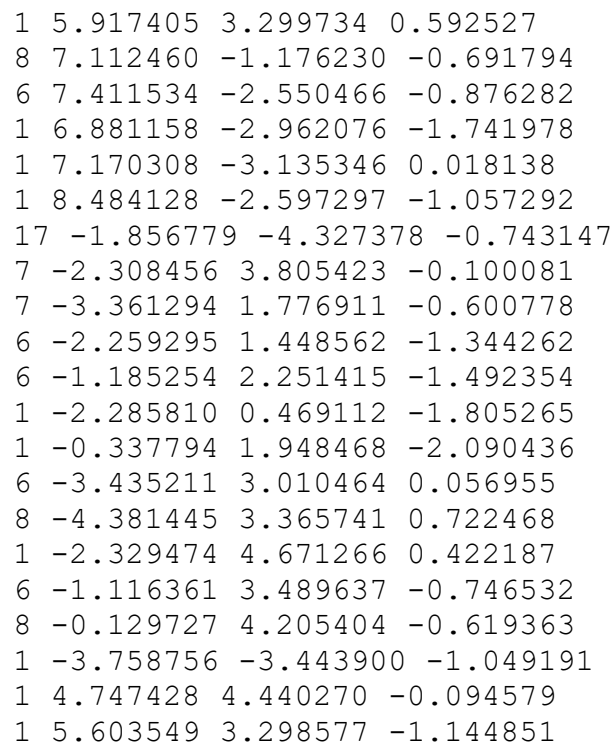




$\begin{array}{llll}1 & 2.764914 & -1.083104 & -0.469076 \\ 1 & 3.851388 & -2.719227 & 0.920318 \\ 8 & 3.570092 & -1.686897 & 2.708029 \\ 1 & 5.734585 & -0.945163 & 1.977042 \\ 6 & 5.948412 & -1.539358 & -0.087843 \\ 1 & 3.072440 & 0.944982 & 1.780554 \\ 7 & 2.824918 & 2.467253 & -2.307355 \\ 7 & 2.981811 & 1.593802 & -0.161229 \\ 6 & 2.315499 & 2.714943 & 0.295305 \\ 6 & 1.905563 & 3.711721 & -0.509742 \\ 1 & 2.090328 & 2.707321 & 1.355791 \\ 1 & 1.374967 & 4.564263 & -0.112151 \\ 8 & 5.172074 & -1.831539 & -1.219517 \\ 1 & 6.771075 & -0.845255 & -0.316047 \\ 1 & 6.394188 & -2.481637 & 0.250745 \\ 1 & 4.808184 & -0.994250 & -1.550911 \\ 1 & 2.612803 & -1.770569 & 2.804957 \\ 6 & 3.249613 & 1.430950 & -1.511495 \\ 8 & 3.803385 & 0.455917 & -1.998966 \\ 1 & 3.026654 & 2.355368 & -3.291654 \\ 6 & 2.153736 & 3.645755 & -1.935426 \\ 8 & 1.843823 & 4.463116 & -2.780644 \\ 1 & -6.678376 & -0.780949 & -2.584946 \\ 1 & -7.086270 & -1.852306 & -1.243532\end{array}$

\section{Structure: TS-5C in Fig. S61}

SCF Energy: $\quad-3586.469364$ hartree SCF Energy + ZPVE: $\quad-3586.028358$ hartree Enthalpy: $\quad-3585.993469$ hartree Free Energy: $\quad-3586.096676$ hartree Free Energy with quasiharmonic correction: $\quad-3586.087634$ hartree

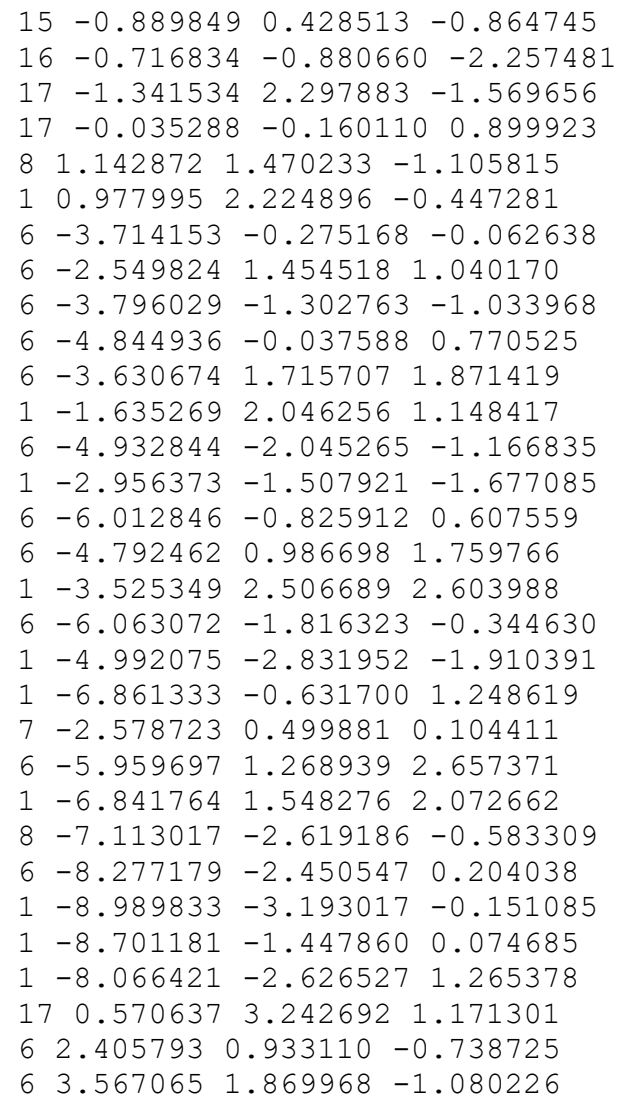




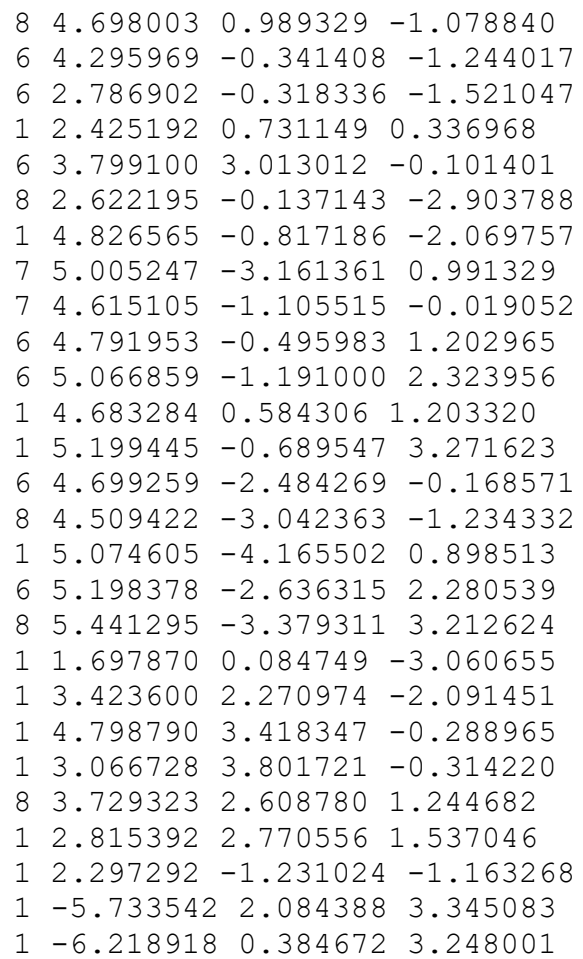

Structure: TS-6a in Fig. S62

SCF Energy: $\quad-4043.181791$ hartree

SCF Energy + ZPVE: -4042.741586 hartree

Enthalpy: $\quad-4042.705965$ hartree

Free Energy: $\quad-4042.811352$ hartree

Free Energy with quasiharmonic correction: $\quad-4042.801717$ hartree

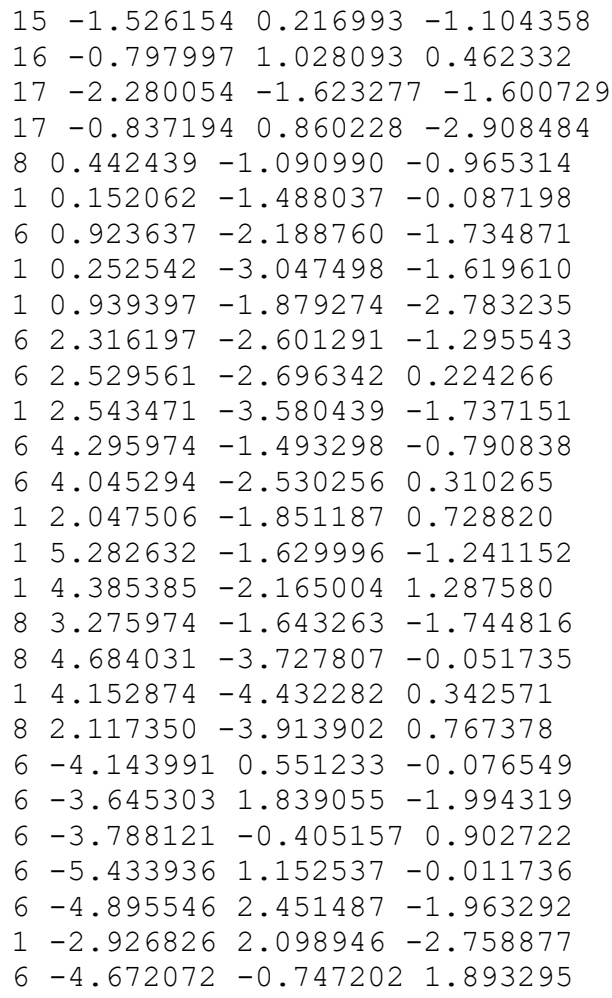




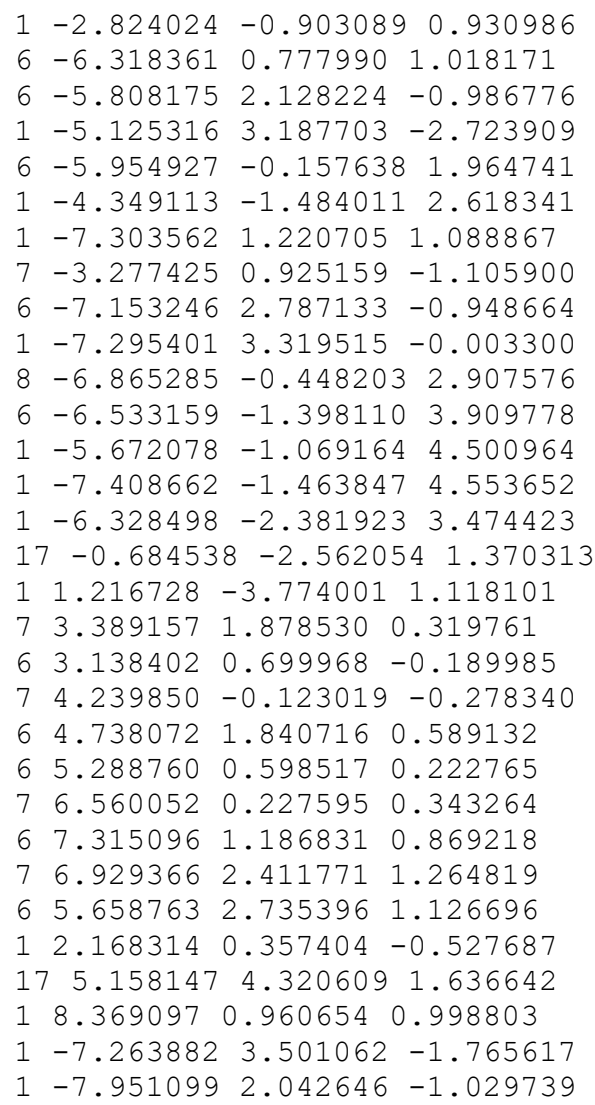

\section{Structure: TS-6b in Fig. $\mathrm{S} 62$}

SCF Energy: $\quad-4043.184278$ hartree $\mathrm{SCF}$ Energy + ZPVE: $\quad-4042.744349$ hartree Enthalpy: $\quad-4042.708935$ hartree 
$\begin{array}{llll}1 & -6.872026 & 2.658076 & 3.583428 \\ 1 & -5.133064 & 2.843870 & 3.242290 \\ 17 & -0.118198 & -0.576226 & 3.046975 \\ 6 & 2.399045 & -1.589396 & 0.412761 \\ 6 & 3.313575 & -2.812014 & 0.544714 \\ 6 & 4.688138 & -2.175359 & 0.752297 \\ 8 & 4.446308 & -0.850175 & 1.263461 \\ 6 & 3.073823 & -0.601693 & 1.382118 \\ 1 & 2.444454 & -1.195668 & -0.607282 \\ 1 & 3.287060 & -3.432547 & -0.360205 \\ 8 & 2.971475 & -3.544298 & 1.696406 \\ 1 & 5.237978 & -2.741411 & 1.512215 \\ 6 & 5.511367 & -2.071966 & -0.524200 \\ 1 & 2.706673 & -0.765680 & 2.402985 \\ 8 & 4.776685 & -1.574538 & -1.612040 \\ 1 & 6.401374 & -1.461598 & -0.311282 \\ 1 & 5.855784 & -3.076716 & -0.794847 \\ 1 & 4.561584 & -0.640402 & -1.426772 \\ 1 & 2.006303 & -3.568856 & 1.722858 \\ 7 & 1.999425 & 2.878463 & 1.337960 \\ 6 & 2.115334 & 1.685645 & 1.856430 \\ 7 & 2.831466 & 0.795975 & 1.081301 \\ 1 & 1.657656 & 1.350711 & 2.779433 \\ 6 & 3.200723 & 1.491279 & -0.038418 \\ 6 & 2.675237 & 2.784730 & 0.144120 \\ 6 & 2.926677 & 3.669325 & -0.899187 \\ 7 & 3.607927 & 3.298269 & -1.967975 \\ 6 & 4.052294 & 2.037096 & -2.019160 \\ 7 & 3.890908 & 1.084956 & -1.103011 \\ 17 & 2.339780 & 5.300874 & -0.833568 \\ 1 & 4.606820 & 1.759881 & -2.910231 \\ 6 & -6.439591 & -0.010855 & -2.828557 \\ 1 & -7.236248 & -0.471015 & -2.236121 \\ 1 & -6.610007 & 1.070022 & -2.825046 \\ 1 & -6.522910 & -0.369094 & -3.855258\end{array}$

Structure: TS-6c in Fig. S62

SCF Energy: $\quad-4043.183163$ hartree SCF Energy + ZPVE: -4042.743194 hartree Enthalpy: $\quad-4042.707634$ hartree Free Energy: -4042.812294 hartree

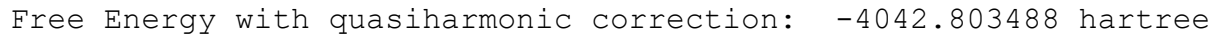
$15 \quad 2.136122-1.290786 \quad 0.022276$
$16 \quad 1.494689-0.4429631 .601422$
$17 \quad 2.322113-0.802304-1.951217$
$17 \quad 1.919224-3.314612-0.090852$
$8-0.125168-1.177231-0.837009$
$1-0.117262-0.200552-1.028758$

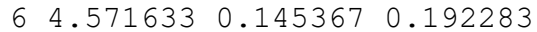
$\begin{array}{lllll}6 & 4.761296 & -2.187574 & 0.513248\end{array}$
$\begin{array}{llll}6 & 3.806172 & 1.298804 & -0.096639\end{array}$

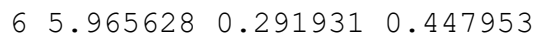
$\begin{array}{lllll}6 & 6.126765 & -2.086455 & 0.768713\end{array}$
$\begin{array}{lllll}1 & 4.268155 & -3.149087 & 0.539759\end{array}$
$\begin{array}{lllll}6 & 4.398535 & 2.534641 & -0.129492\end{array}$
$12.739573 \quad 1.278773-0.301745$

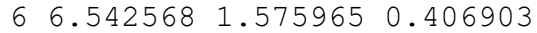

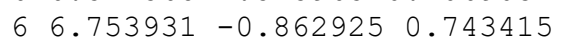
$16.676287-2.993433 \quad 0.989741$
$\begin{array}{lllll}6 & 5.780475 & 2.690883 & 0.124118\end{array}$
$\begin{array}{lllll}1 & 3.766473 & 3.384005 & -0.357829\end{array}$
$17.5990991 .713506 \quad 0.597912$ 


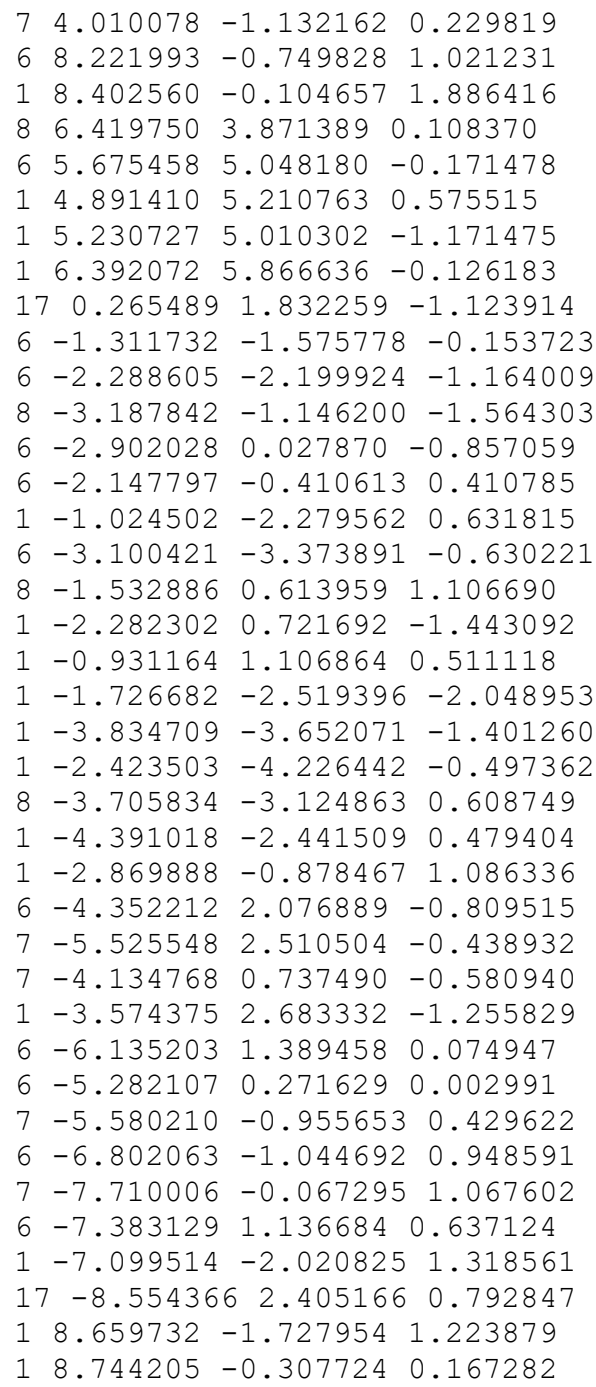

\footnotetext{
Structure: 6-fluoro-4-methylquinoline SCF Energy: $\quad-540.316693$ hartree SCF Energy + ZPVE: -540.159454 hartree Enthalpy: $\quad-540.149520$ hartree Free Energy: $\quad-540.193545$ hartree Free Energy with quasiharmonic correction: -540.193545 hartree

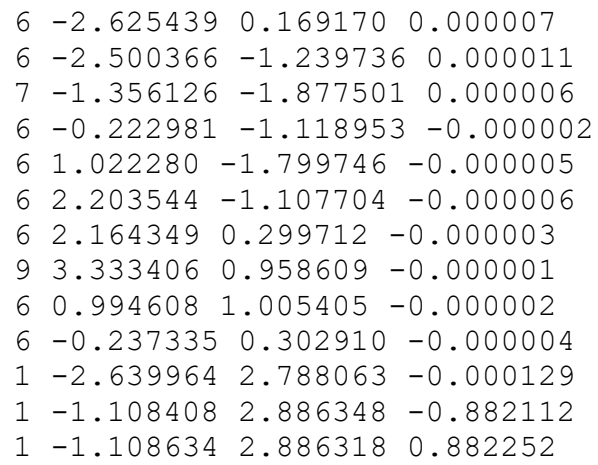




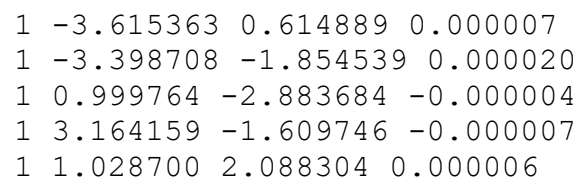

\section{Structure: 4,6-dimethylquinoline}

SCF Energy: $\quad-480.419354$ hartree

SCF Energy + ZPVE: $\quad-480.226043$ hartree

Enthalpy: $\quad-480.215173$ hartree

Free Energy: $\quad-480.261179$ hartree

Free Energy with quasiharmonic correction: -480.261133 hartree

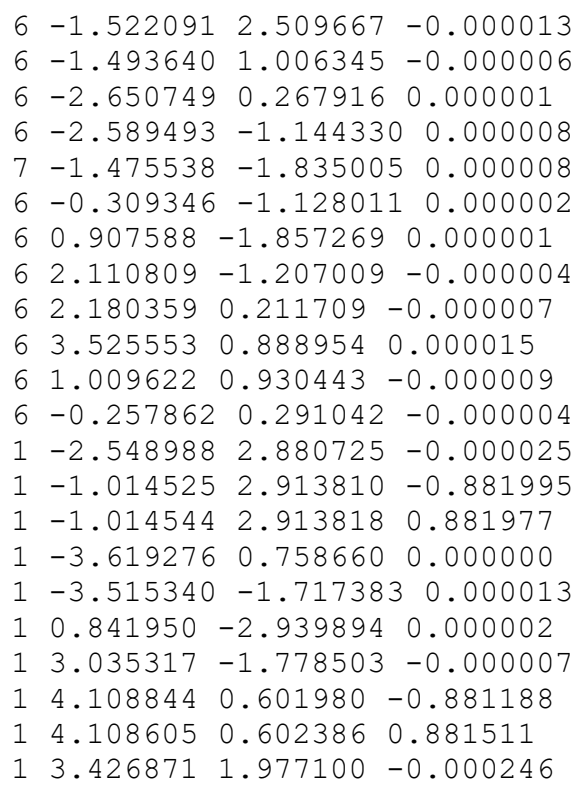


$11.0553552 .015596-0.000014$

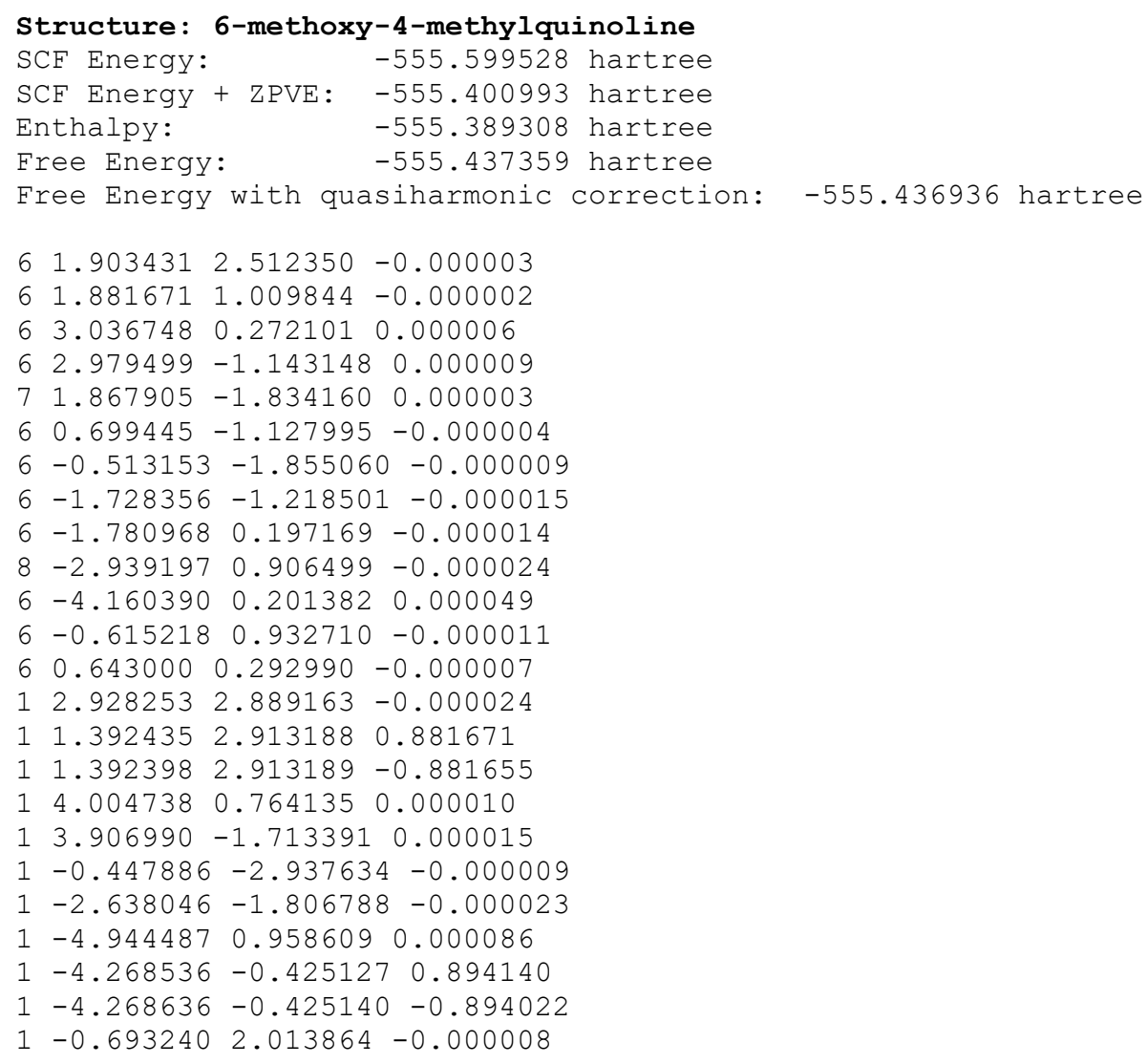

\section{Structure: 08}

SCF Energy:

Enthalpy: $\quad-1020.535231$ hartree

Free Energy: $\quad-1020.601362$ hartree

Free Energy with quasiharmonic correction: -1020.598177 hartree 
$\begin{array}{llll}6 & -3.710502 & -1.399936 & -0.625763 \\ 6 & -3.656202 & -0.360657 & -1.781595 \\ 1 & -3.989281 & 1.819545 & -0.247705 \\ 1 & -2.535997 & 1.445206 & -2.224002 \\ 1 & -1.273262 & -2.068363 & -0.594805 \\ 1 & -0.388470 & -0.002848 & 1.444242 \\ 1 & -0.816344 & 3.685469 & 1.448078 \\ 1 & -1.580993 & 2.221590 & 2.266234 \\ 1 & -1.889021 & 3.194167 & -0.630112 \\ 1 & -0.907087 & -0.441675 & -2.186250 \\ 1 & -0.483398 & 0.754306 & -0.975093 \\ 1 & -1.700991 & -2.041925 & 1.871790 \\ 1 & 0.792523 & 1.485768 & 0.737065 \\ 1 & 4.667402 & 2.377219 & -0.797668 \\ 1 & 5.142716 & -0.072365 & -1.090643 \\ 1 & 2.985436 & -3.948693 & -0.319037 \\ 1 & 0.735169 & -3.408845 & 0.617366 \\ 1 & -4.103014 & 0.194824 & 1.379021 \\ 1 & -2.433905 & 0.455037 & 1.827005 \\ 1 & -4.706386 & -1.439918 & -0.173987 \\ 1 & -3.478450 & -2.406791 & -0.985419 \\ 1 & -4.630529 & 0.118765 & -1.923605 \\ 1 & -3.394719 & -0.842692 & -2.729145\end{array}$

Structure: $\mathrm{Q9}$

-921.720764 hartree

SCF Energy + ZPVE: -921.337544 hartree

Enthalpy: $\quad-921.319077$ hartree

Free Energy: $\quad-921.383760$ hartree

Free Energy with quasiharmonic correction: -921.380329 hartree

$6-5.916882-1.1857160 .266931$

$6-4.947904-0.277448 \quad 0.207595$

$6-3.490518-0.589926 \quad 0.021704$

$\begin{array}{lllll}6 & -2.636157 & -0.279521 & 1.273511\end{array}$

$6-1.180585-0.6465610 .942992$

$6-0.670900 \quad 0.360700-0.111519$

$\begin{array}{lllll}6 & 0.172245 & -0.260432 & -1.244435\end{array}$

$\begin{array}{lllll}8 & 0.379136 & 0.698294 & -2.251303\end{array}$

$61.473251-0.808774-0.696670$

$\begin{array}{lllll}6 & 2.546289 & 0.019869 & -0.240386\end{array}$

$\begin{array}{lllll}6 & 2.572749 & 1.435455 & -0.371261\end{array}$

$\begin{array}{llll}6 & 3.623109 & 2.164398 & 0.123745\end{array}$

$\begin{array}{lllll}1 & 3.628700 & 3.243898 & 0.010678\end{array}$

$\begin{array}{lllll}6 & 4.707650 & 1.523905 & 0.764757\end{array}$

$\begin{array}{lllll}6 & 4.722980 & 0.160145 & 0.887778\end{array}$

$\begin{array}{llll}6 & 3.650731 & -0.623012 & 0.389057\end{array}$

$\begin{array}{lllll}7 & 3.741270 & -1.975585 & 0.549739\end{array}$

$\begin{array}{lllll}6 & 2.752448 & -2.700308 & 0.090653\end{array}$

$\begin{array}{lllll}6 & 1.603460 & -2.165398 & -0.533953\end{array}$

$\begin{array}{llll}7 & -1.789326 & 1.115524 & -0.708310\end{array}$

$\begin{array}{lllll}6 & -2.857989 & 0.213711 & -1.158887\end{array}$

$\begin{array}{lllll}6 & -2.333288 & 2.014340 & 0.318764\end{array}$

$\begin{array}{llll}6 & -2.703769 & 1.221703 & 1.602412\end{array}$

$1-3.399518-1.663798-0.181786$

$\begin{array}{llll}1 & -2.999346 & -0.871652 & 2.118014\end{array}$

$\begin{array}{lllll}1 & -0.040335 & 1.111221 & 0.377432\end{array}$

$1-0.386745-1.119905-1.653207$

$\begin{array}{lllll}1 & -6.955817 & -0.903862 & 0.403939\end{array}$

$\begin{array}{lllll}1 & -5.703335 & -2.248277 & 0.178885\end{array}$

$\begin{array}{llll}1 & -5.209489 & 0.778378 & 0.291167\end{array}$

$\begin{array}{lllll}1 & -0.552927 & -0.613697 & 1.838065\end{array}$

$1-1.134345-1.674200 \quad 0.560997$ 
$\begin{array}{llll}1 & -0.402752 & 1.273389 & -2.186116 \\ 1 & 1.766554 & 1.922161 & -0.904320 \\ 1 & 5.532237 & 2.115983 & 1.148929 \\ 1 & 5.543836 & -0.366145 & 1.362441 \\ 1 & 2.840172 & -3.778389 & 0.215243 \\ 1 & 0.823221 & -2.838398 & -0.876831 \\ 1 & -2.451928 & -0.462841 & -1.915380 \\ 1 & -3.615229 & 0.823373 & -1.662181 \\ 1 & -3.210333 & 2.512513 & -0.107302 \\ 1 & -1.591061 & 2.790051 & 0.529355 \\ 1 & -2.001089 & 1.443930 & 2.412417 \\ 1 & -3.698687 & 1.497566 & 1.963251\end{array}$

Structure: $\mathbf{Q 1 0}$

SCF Energy: $\quad-961.031285$ hartree

SCF Energy + ZPVE: -960.620444 hartree

Enthalpy: $\quad-960.600142$ hartree

Free Energy: $\quad-960.669005$ hartree

Free Energy with quasiharmonic correction: -960.665142 hartree

$\begin{array}{lllll}6 & 3.339462 & 2.762064 & -2.337898\end{array}$

$\begin{array}{lllll}6 & 2.695348 & 1.939264 & -1.516056\end{array}$

$\begin{array}{lllll}6 & 3.360347 & 0.975501 & -0.574470\end{array}$

$6 \quad 3.127133-0.505649-0.966287$

$\begin{array}{lll}6 & 1.628292-0.846428 & -0.930733\end{array}$

$6 \quad 1.070962-0.3559580 .421798$

$\begin{array}{lllll}6 & 0.065662 & -1.312831 & 1.094547\end{array}$

$8-0.194111-0.8702362 .403372$

$\begin{array}{llll}6 & -1.194620 & -1.421465 & 0.262127\end{array}$

$\begin{array}{llll}6 & -2.140778 & -0.358120 & 0.125804\end{array}$

$\begin{array}{llll}6 & -2.081846 & 0.860583 & 0.856554\end{array}$

$\begin{array}{llll}6 & -2.995696 & 1.865827 & 0.655632\end{array}$

$\begin{array}{lllll}6 & -2.930075 & 3.153724 & 1.433958\end{array}$

$6-4.0306921 .676277-0.298001$

$\begin{array}{lllll}6 & -4.133997 & 0.509514 & -1.002592\end{array}$

$6-3.197090-0.538675-0.809942$

$7-3.364515-1.672082-1.549583$

$6-2.495290-2.635734-1.371819$

$6-1.398807-2.555090-0.485461$

$\begin{array}{llll}7 & 2.161454 & -0.058578 & 1.370658\end{array}$

$\begin{array}{llll}6 & 2.858229 & 1.142163 & 0.899078\end{array}$

$\begin{array}{llll}6 & 3.122191 & -1.171075 & 1.437311\end{array}$

$\begin{array}{lllll}6 & 3.833617 & -1.385548 & 0.074547\end{array}$

$14.4408181 .159485-0.611012$

$13.536250-0.685085-1.964318$

$\begin{array}{lllll}1 & 0.547485 & 0.595199 & 0.274940\end{array}$

$\begin{array}{lllll}1 & 0.516740 & -2.319817 & 1.121283\end{array}$

$\begin{array}{lllll}1 & 2.808098 & 3.437258 & -3.000726\end{array}$

$14.425900 \quad 2.789043-2.376155$

$\begin{array}{lllll}1 & 1.604572 & 1.951614 & -1.506237\end{array}$

$11.502565-1.931276-1.036566$

$11.086132-0.387936-1.761669$

$\begin{array}{lllll}1 & 0.626440 & -0.414723 & 2.659066\end{array}$

$\begin{array}{lllll}1 & -1.316854 & 0.969072 & 1.615555\end{array}$

$\begin{array}{lllll}1 & -3.848681 & 3.312036 & 2.008593\end{array}$

$\begin{array}{lllll}1 & -2.090548 & 3.154945 & 2.132978\end{array}$

$\begin{array}{lllll}1 & -2.815728 & 4.012350 & 0.763603\end{array}$

$\begin{array}{lllll}1 & -4.754811 & 2.471363 & -0.456087\end{array}$

$\begin{array}{lllll}1 & -4.925757 & 0.343738 & -1.725027\end{array}$

$1-2.643491-3.540210-1.959426$

$\begin{array}{lllll}1 & -0.715314 & -3.395422 & -0.407723\end{array}$

$\begin{array}{llll}1 & 2.174029 & 1.993051 & 0.979792\end{array}$

$\begin{array}{llll}1 & 3.697132 & 1.336947 & 1.574162\end{array}$ 


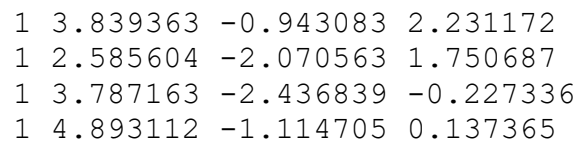

Structure: I (Tables14)

SCF Energy: $\quad-441.114376$ hartree 


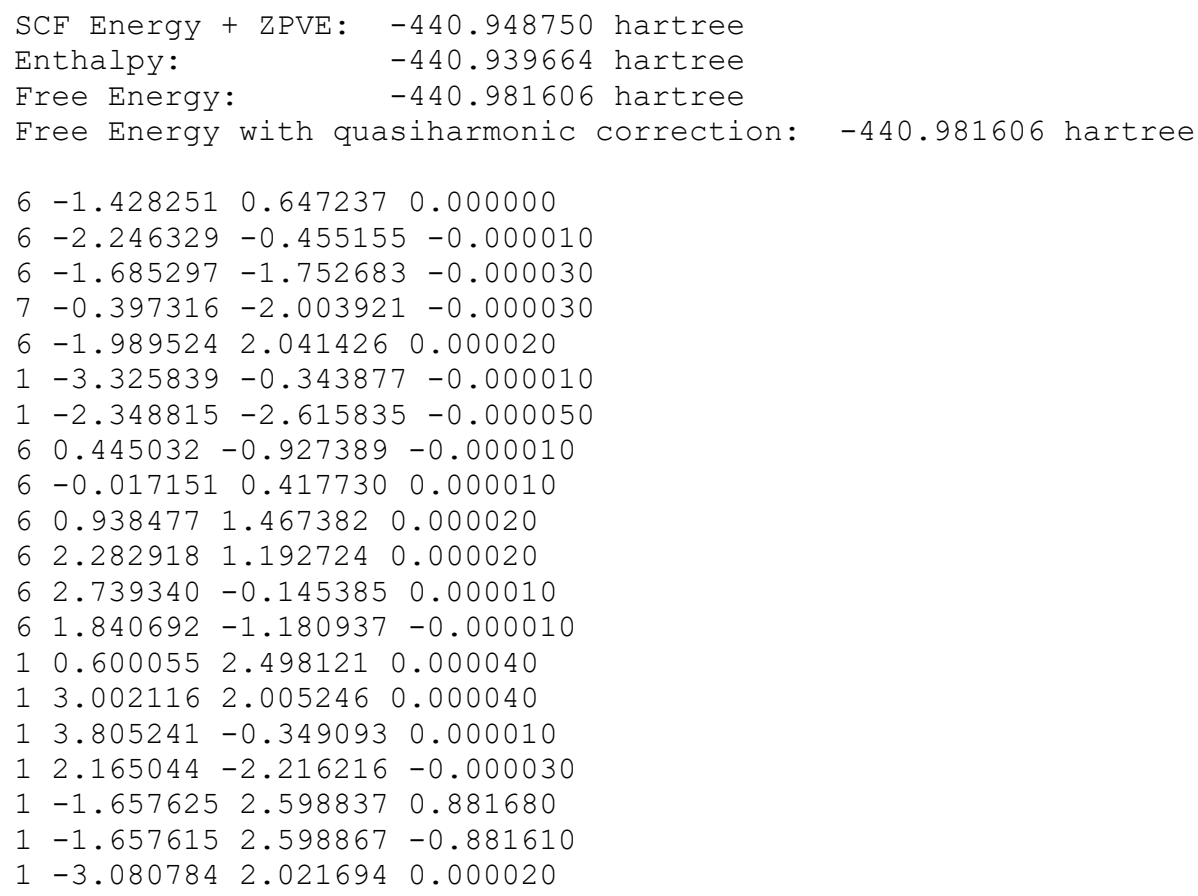

\section{Structure: $\mathrm{I} \bullet \mathrm{H}^{+}($TableS14)}

SCF Energy: $\quad-441.565604$ hartree

SCF Energy + ZPVE: -441.385899 hartree

Enthalpy: $\quad-441.376657$ hartree

Free Energy: $\quad-441.418861$ hartree

Free Energy with quasiharmonic correction: -441.418861 hartree

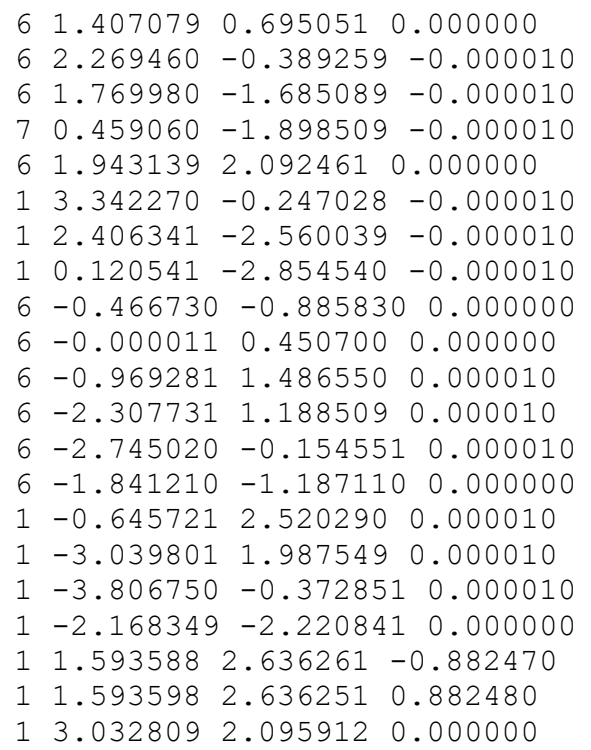

\section{Structure: IIa (Tables14)}

SCF Energy: $\quad-480.424484$ hartree SCF Energy + ZPVE: -480.231316 hartree 


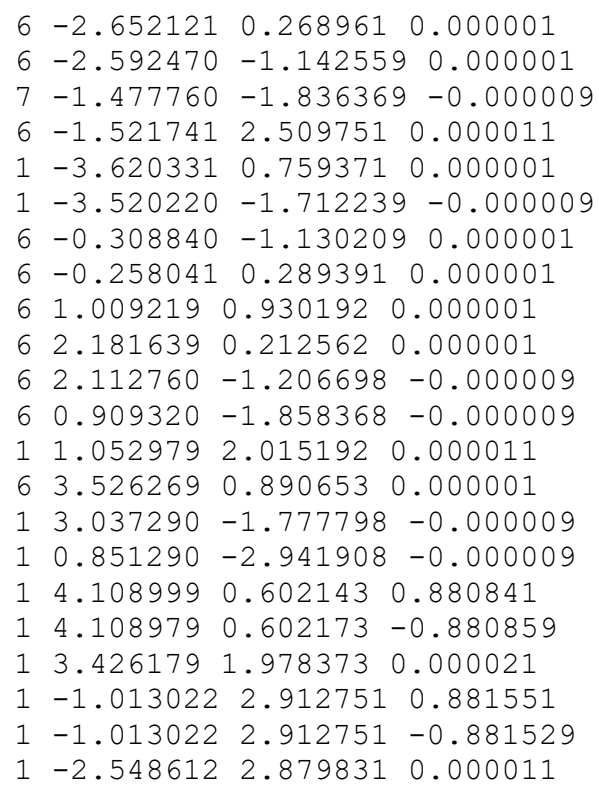

\section{Structure: IIa $\bullet \mathrm{H}^{+}$(TableS14)}

SCF Energy: $\quad-480.877028$ hartree

SCF Energy + ZPVE: $\quad-480.669457$ hartree

Enthalpy: $\quad-480.658435$ hartree

Free Energy: $\quad-480.704772$ hartree

Free Energy with quasiharmonic correction: -480.704659 hartree

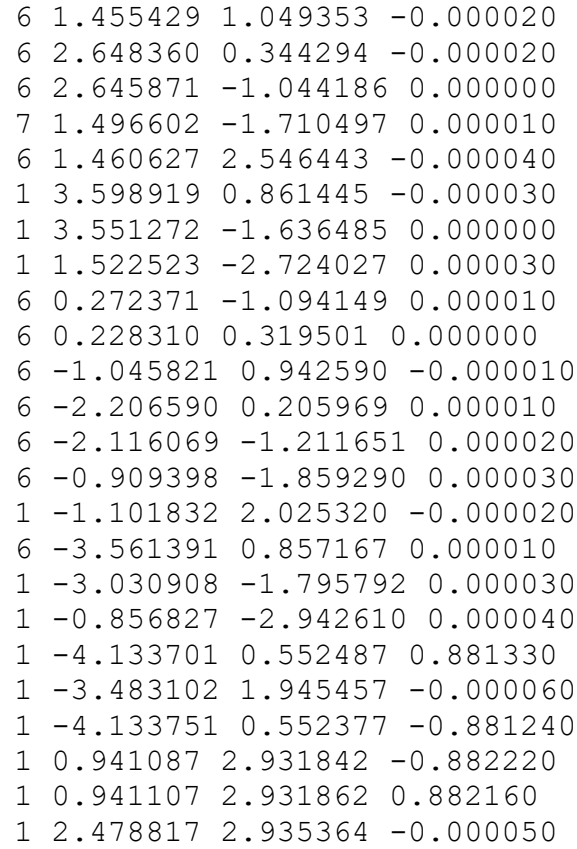

\section{Structure: IIb (Table S14)}

SCF Energy: $\quad-555.608215$ hartree SCF Energy + ZPVE: -555.409731 hartree Enthalpy: $\quad-555.398109$ hartree Free Energy: $\quad-555.445866$ hartree

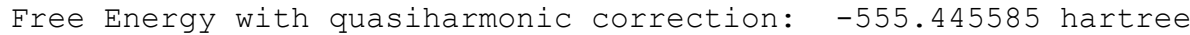

$6-1.550451 \quad 1.1976310 .000039$ 


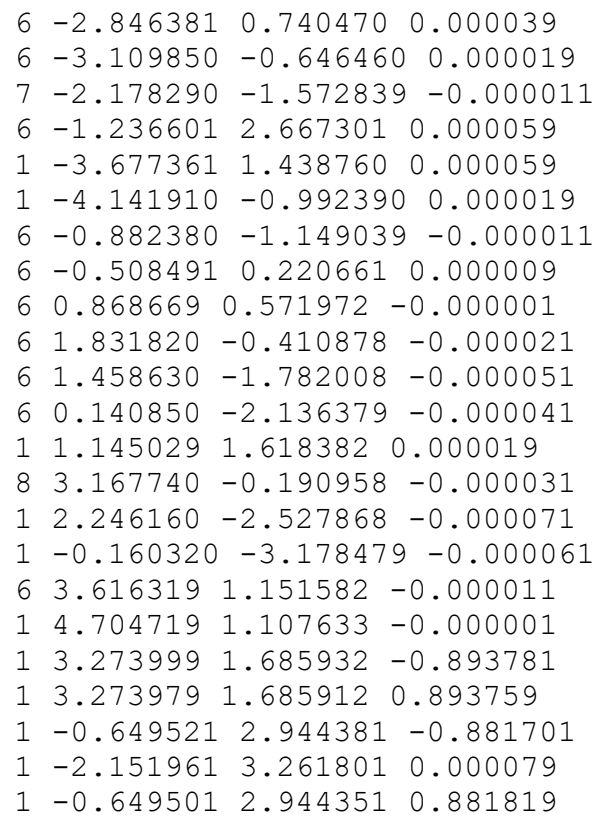

\section{Structure: $\mathrm{IIb} \cdot \mathrm{H}^{+}$(Table S14)}

-556.060643 hartree

SCF Energy + ZPVE: $\quad$-555.847512 hartree

Enthalpy: $\quad-555.835818$ hartree

Free Energy: $\quad-555.883569$ hartree

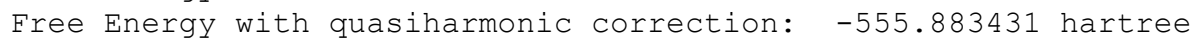

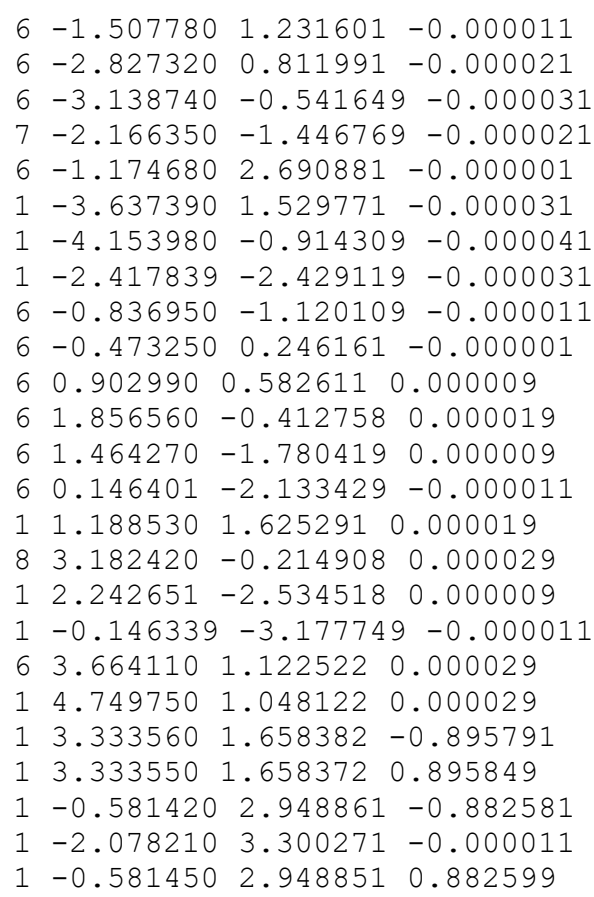

\section{Structure: IIc (Table S14)}

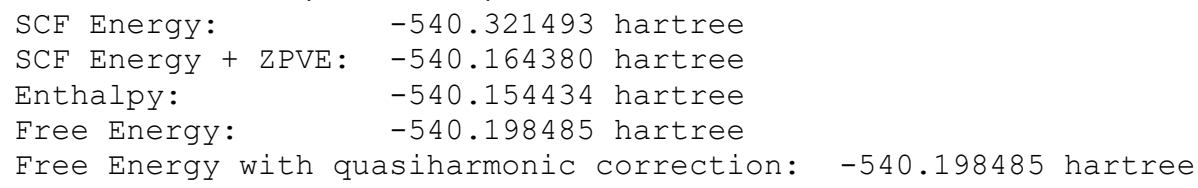




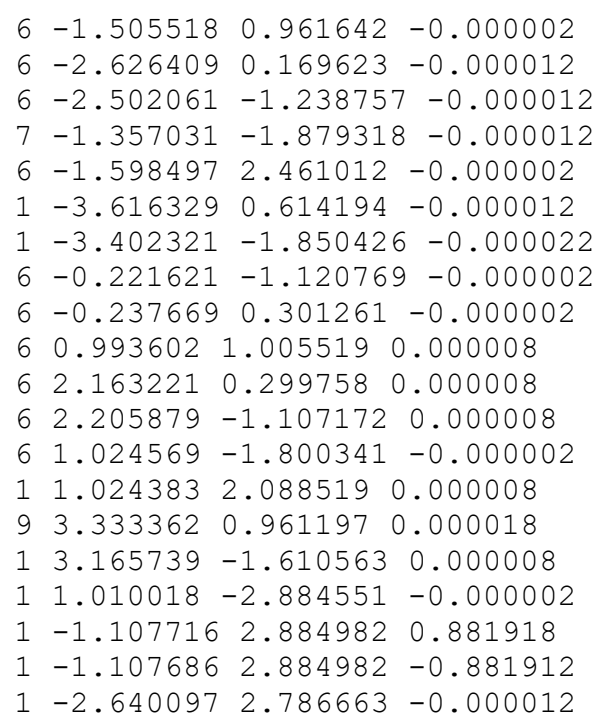

\section{Structure: IIC $\cdot \mathrm{H}^{+}$(Table S14)}

SCF Energy: $\quad-540.769645$ hartree

SCF Energy + ZPVE: -540.598288 hartree

Enthalpy: $\quad-540.588163$ hartree

Free Energy: $\quad-540.632593$ hartree

Free Energy with quasiharmonic correction: -540.632593 hartree

61.4682891 .0058020 .000001

$62.625300 \quad 0.247403 \quad 0.000001$

$\begin{array}{ll}6 & 2.559351-1.141077-0.000009\end{array}$

$71.383102-1.755079-0.000009$

61.5370482 .5002020 .000011

$\begin{array}{lllll}1 & 3.598989 & 0.719804 & 0.000001\end{array}$

$13.438482-1.771296-0.000009$

$11.364963-2.768849-0.000009$

$\begin{array}{llll}6 & 0.186751 & -1.085210 & 0.000001\end{array}$

$\begin{array}{lllll}6 & 0.208010 & 0.330000 & 0.000001\end{array}$

$\begin{array}{llll}6 & -1.029791 & 1.016679 & 0.000001\end{array}$

$\begin{array}{llll}6 & -2.189950 & 0.293608 & 0.000001\end{array}$

$\begin{array}{llll}6 & -2.209819 & -1.114502 & 0.000001\end{array}$

$\begin{array}{lllll}6 & -1.025948 & -1.803531 & 0.000001\end{array}$

$1-1.0729922 .0981090 .000011$

$\begin{array}{lllll}9 & -3.360721 & 0.930206 & 0.000001\end{array}$

$1-3.161918-1.6309630 .000001$

$1-1.018887-2.888231-0.000009$

$\begin{array}{llll}1 & 1.034937 & 2.907141 & -0.882699\end{array}$

$\begin{array}{lllll}1 & 1.034927 & 2.907131 & 0.882711\end{array}$

$\begin{array}{llll}1 & 2.570817 & 2.844613 & 0.000011\end{array}$ 


\section{References}

(1) Frisch, M. J.; Trucks, G. W.; Schlegel, H. B.; Scuseria, G. E.; Robb, M. A.; Cheeseman, J. R.; Scalmani, G.; Barone, V.; Petersson, G. A.; Nakatsuji, H.; et al. Gaussian 16, Rev. A.03; Gaussian, Inc.: Wallingford, CT 2016.

(2) Chai, J.-D.; Head-Gordon, M. Long-Range Corrected Hybrid Density Functionals with Damped Atom-Atom Dispersion Corrections. Phys. Chem. Chem. Phys. 2008, 10 (44), 6615-6620. https://doi.org/10.1039/b810189b.

(3) Ribeiro, R. F.; Marenich, A. V.; Cramer, C. J.; Truhlar, D. G. Use of Solution-Phase Vibrational Frequencies in Continuum Models for the Free Energy of Solvation. J. Phys. Chem. B 2011, 115 (49), 14556-14562. https://doi.org/10.1021/jp205508z.

(4) AMPAC 10. Semichem, Inc.: Shawnee, KS 1992-2013.

(5) Legault, C. Y. CYLview, version 1.0b; Université de Sherbrooke: Quebec, Canada, 2009.

(6) Schrödinger Release 2019-4. Schrödinger, LLC: New York, NY 2019.

(7) Roos, K.; Wu, C.; Damm, W.; Reboul, M.; Stevenson, J. M.; Lu, C.; Dahlgren, M. K.; Mondal, S.; Chen, W.; Wang, L.; et al. OPLS3e: Extending Force Field Coverage for Drug-Like Small Molecules. J. Chem. Theory Comput. 2019, 15 (3), 1863-1874. https://doi.org/10.1021/acs.jctc.8b01026.

(8) Harder, E.; Damm, W.; Maple, J.; Wu, C.; Reboul, M.; Xiang, J. Y.; Wang, L.; Lupyan, D.; Dahlgren, M. K.; Knight, J. L.; et al. OPLS3: A Force Field Providing Broad Coverage of Drug-like Small Molecules and Proteins. J. Chem. Theory Comput. 2016, 12 (1), 281-296. https://doi.org/10.1021/acs.jctc.5b00864. 